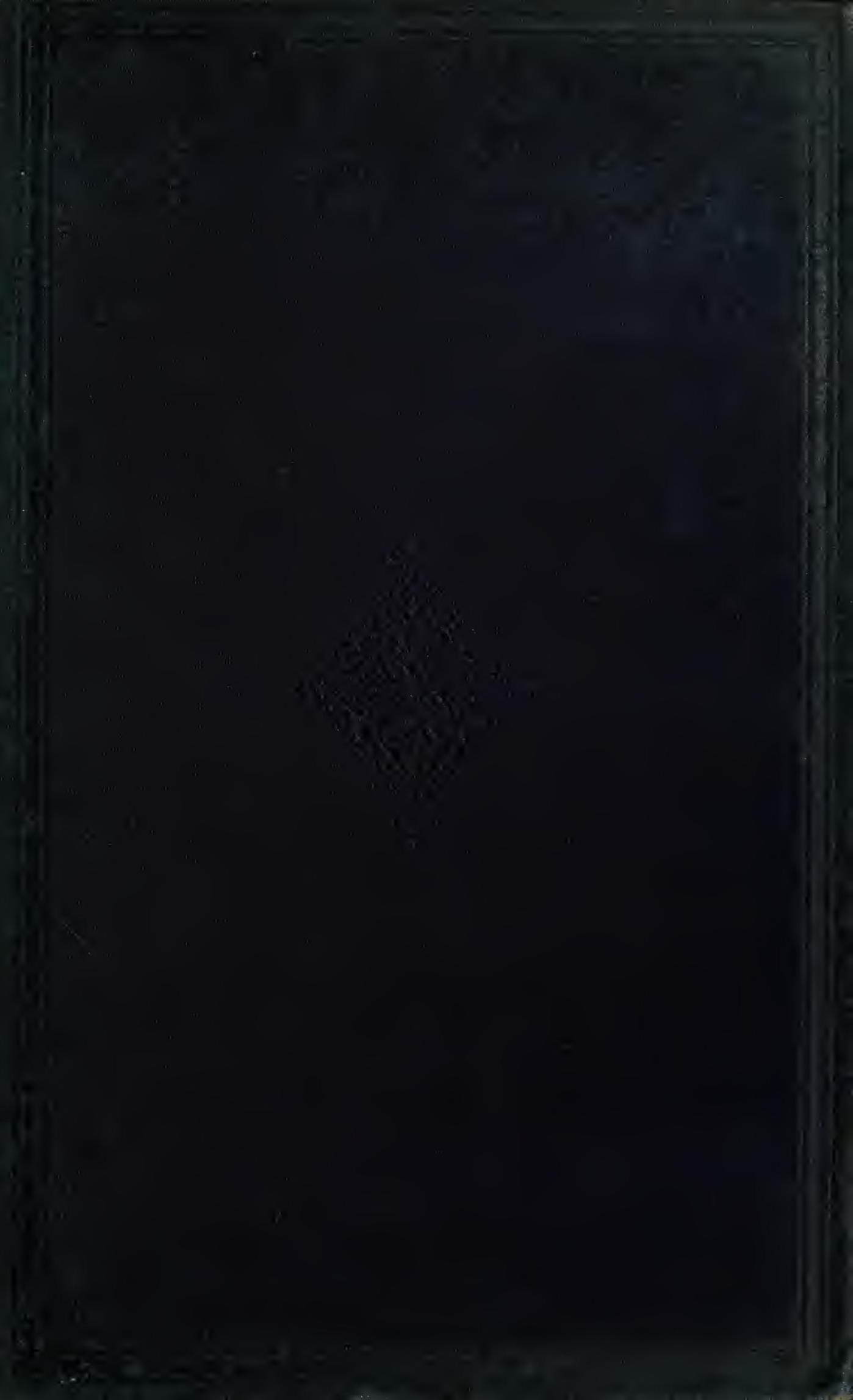








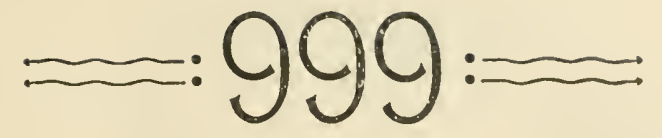

\title{
QUERIES WITH ANSWERS
}

....UPON....

\section{Agricultural and Horticultural \\ Subjects.}

\author{
By \\ BURNET LANDRETH, \\ Foreign Member of the Agricultural Societies of Japan, Ciile, Mexico, France, \\ Horticultural of London, Society of Arts, London, \\ Acclimatization of Brazil, L'Academie Royale de Suede, \\ Chevalier and Officier du Merite Agricole de France.
}

\author{
PUBLISHED BY \\ DAVID LANDRETH \& SONS, \\ Seed Farmers and Merchants, \\ Established 1784, \\ PHILADELPHIA.
}

COPYRIGHT, 1895.

Philadelphia :

Press of MACCalla \& CoMpaNy INCORPoRated,

$237-9$ DOCE STREET. 


\section{chanda.}

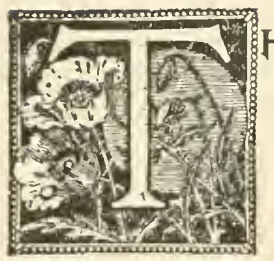

HESE 999 QUESTIONS

represent only a small portion of the Queries which have been sent to the firm of the author, and which have presented themselves to practical minds, dwelling upon the subjects of field work connected with agriculture and horticulture, more particularly in the special branch of Vegetable Gardening.

Among farmers and gardeners not enough thought is given to the why and wherefore, or cause and effect, for, as a rule, they go on year after year without profiting by the personal opportunities afforded them of observation, or by the results of experiments at scientific stations. Every year a new series of cultivators, both of farm and garden, spring into existence, few of them profiting by, few indeed knowing anything about, the experiences of their predecessors.

With rare exceptions the young farmer and gardener does not take up his work from the scientific side, but strictly from the laborer's side; and he begins at the bottom, meeting the same difficulties as did his father and too often not acquiring information beyond what his father possessed.

This should not be; agriculture should be taught in all our public schools of country districts, as it has been taught for years in Germany and Austria. It should be elevated as an art; in its higher estate it already is an art. No pursuit possesses a greater scope for development; the field is almost unoccupied by leaders, scientific and practical.

Since this Book has gone to press, many more Queries have been presented, and they, with others, will be comprehended in a second Volume, now being prepared, to be issued a year hence, which will comprise over 1000 additional Queries.

The Author asks readers to send him at once, and any time hereafter, additional questions that he may answer them, the responses subsequently to be embodied in the second volume. 


\section{QUERIES AND ANSWERS.}

. . SELECTEd FROM. .

\section{LandReths' Inquiry Book.}

MANY of the inquiries made of the Seed Merchant by amateurs and practical gardeners are very difficult to answer, as they arise from the varied thought and experience of the inquirers, the outgrowth of every physical diversity of soil, climate and condition, as well as from the temperament and mood of the writers.

Out of the many thousands of queries made of us there may be selected a few from our Inquiry Book which it may be practical to repeat, with the responses made, as they may meet a need for similar information for some of the readers of this volume. They might be better grouped or classified, but are printed just as they have been recorded.

Readers of this book may not in all things agree with the answers made; that is their privilege, as many queries are subject to different interpretations. The book is not published for the scientific, nor for those who already know it all before they read it.

1. QUERY. What is the distinction between a fruit and a vegetable?

Answer. In a physiological sense a fruit is borne upon a flower stem vegetable. and is a growth following the development of a flower, and, except under abortive conditions or failing of pollination, containing within itself or upon itself the seeds for the perpetuation of its species. Perhaps, to meet a popular understanding, a ready definition of a fruit might be an edible growth upon a tree or bush, containing seeds and having a sweet or sour flavor.

2. Q. If a fruit is a consequential development of inflorescence and con- Nuts. tains a seed, is a nut a fruit?

A. A nut or hard-shelled seed, if contained within a pulpy envelope, is, with its covering, a fruit under the previous definition; but under the usual understanding a fruit must be an accumulation of soft, pulpy tissue. Some nuts-as the cocoanut, the walnut and the hickory-are 
enclosed in a thick tissue of growth, but the enveloping material is unpalatable and indigestible. In the case of nut-bearing plants of habits fixed through original conditions or through selection based upon hereditary development, the seed or nut is developed at the expense of the surround. ing tissue.

Grains. $\quad 3$ Q. What is a grain?

A. A grain is a seed suitable for use by man for grinding or crushing to meal for cattle feeding or human food.

Culinary Vegetables.

Bulbs.

Tubers.

Offsets.

Broceoli.

Cow Pea.

Wheat.
4. Q. What is a culinary vegetable?

A. It is a plant producing, above or below ground, a development of edible tissue, as the bulb of a turnip, the enlarged stalk of a kohl rabi, the head of a cabbage, or the half-abortive or abnormally developed buds of the caulifiower. A culinary vegetable generally requires cooking to fit it for human food, but not always, as exampled in the radish, lettuce, cress. A culinary vegetable in the exact sense cannot contain seeds, as it is a product developed previous to inflorescence.

5. Q. What is a bulb?

A. It is an underground bud containing within itself a capacity for reproducing its kind. It is generally globular in form and is composed of scales or coats, one within another, familiar examples being the onion and hyacinth.

6. Q. What is a tuber?

A. A tuber is a solid, fleshy development from a root and containing buds or eyes capable of producing its like; a familiar example of the tuber being the potato?

7. Q. What are offsets?

A. They are young bulbs or bulblets formed on the sides of old bulbs. These broken off produce full-sized buds.

8. Q. What is the distinction between broccoli and cauliflower?

A. Broccoli usually has a taller stem than cauliflower, leaves narrower and stiffer, generally undulating, ribs broad and leaf stalks long; the texture of the heads not so fine nor so white as cauliflower; the flower head of a stronger cabbage taste. Broccoli has an advantage over cauliflower in greater hardiness. It is less rapid in growth, and generally the plants are carried over Winter to develop in early Spring. Broccoli should be better known and more largely cultivated in the northern sections of the Union.

9. Q. Is a Southern cow pea, a pea or a bean?

A. It is a bcan; the outward and unscientific distinction between peas and beans being that, as a rulc, beans have fleshy edible pods, distinctly marked eyes, smooth surface and of a far greater variation of color than peas.

10. Q. Have bearded wheats any advantage over beardless sorts?

A. Bearded wheats possess a higher percentage of gluten than beardless variety, and as gluten is the essentially nutritive element, its percentage is a most important matter. The people of new wheat countries, as 
our Northwestern States, the new lands of the La Platte and Australia, are generally tall and muscular, which physical condition is attributed to the richer glutenous wheat grown on new lands.

11. Q. What advantage is there in the growing of early wheats over Wheat. late wheats?

$\Lambda$. Early wheats are desirable as their habit more quickly removes them from the danger of red rust.

12. Q. What is pollen?

Pollen.

A. It is the fertilizing agent of plants, consisting of a yellow powder formed of cells of from $\frac{1}{300}$ to $\frac{1}{1000}$ of an inch in diameter, each containing minute granules from $\frac{1}{1000}$ to $\frac{1}{3000 \sigma}$ of an inch in diameter. These minute granules produced by the stamens must be brought in contact with the pistil, and one or more pass in to and through it till it reaches the base of the pistil. The pollen reaches the pistil by various nieans, as by the violent bursting of the stamens, by currents of air and by insects. The length of time over which the pollen of ordinary plants retains its vitality varies from a few hours to many days, with a number of plants for many months, and with a few plants for many years. The quantity of pollen produced is enormous, the sulphur showers from pine forests consisting of pollen. Some plants producing 250,000 grains to the single flower.

13. Q. What vegetables will mix, if planted in proximity?

A. Only those of the same family, as for example, beans with beans.

Hybridization.

It is impossible to mix beans with peas, or squashes with tomatoes. Some vegetables looked upon as distinct, as for example, watermelon, cantaloupe, squashes, cucumber, pumpkin and gourds, are all of one family, and will mix one with the other.

14. Q. Will rouncl-podded peas stand more cold, wet weather than Peas. wrinkled peas?

A. Yes. Wrinkled peas, which are soft, are seldom ripened with the same completeness as round peas, which are hard, and they are more likely to decay under the same soil conditions-decomposition setting in earlier-in fact, they have less vitality and less physical vigor.

15. Q. What is a gourd?

Gourd.

A. Scientifically, it may be defined as a member of that family from which has sprung ald the varieties of squashes and pumpkins, which edible fruits are yet comprised in the same general classification with many which are unedible. The edible varieties are those botanically indicated as maxima, mochata and pepo; the first having stalks round, without furrows, and with foliage large, broad, kidney-shaped, and covered with hairs; examples, Valparaiso, Hubbard, Mammoth. The second with stalks slightly furrowed, swollen where they join the fruit, leaves lobed or angular, deeply indented and bloated with air bubbles, seeds hairy and covered with a silvery membrane; examples, Canada Crookneck, Yokohama. The third with stalks sleudor, fruit stoms fivesided and becoming woody, foliage deeply indented and hairy ; examples, White Bush, Vegetable IIarrow, Cococella, Tours. The unedible varie. 
ties to which custom attaches the name of gourd have a hard, woody, dry shell and a flavor so bitter as to render them unedible.

Potatoes. 16. Q. Is the Irish potato a native of Ireland?

A. No! It is a native American, improperly called Irish because the Irish people cultivated it to such an extent at one time as to be the principal article of food. No American should call it Irish. Its true name is the potato, simply the potato, be it white, yellow or red, round or oblong.

The sweet potato is not a potato at all ; it is called so through an erroneous custom.

Sweet Potato. 17. Q. If the sweet potato is not a potato, what is it?

A. It belongs to the same race or family as the yam, which family is not native to America, but is found in Africa and India.

Wild

18. Q. Can good potatoes be developed from the wild sorts of Arizona Potatoes. and Mexico?

A. Yes, the writer developed several fine sorts after four years' culture and selection, unfortunately losing them by frost during winter.

Potatoes

19. Q. How long will it take to develop edible-sized potatoes from the from the true seed ball?

seed.

A. About three years. Of course it is all a speculation, for nineteen out of twenty of the seedlings are inferior to present standard sorts, those of good form and quality being like prizes in a lottery; but when they are good they often pay handsomely.

Potatoes, Size 20. Q. Which size seed potatoes produce best results all things considfor Planting. ered?

A. Medium size cut into halves.

Cutting 21. Q. If my potatoes for planting are all large size, how small should Potatoes. I cut them?

A. None smaller than a black walnut.

Potato Skins. 22. Q. Why are the skins of my potatoes eaten and scaly?

A. Sometimes from worms, which lime will drive off. Sometimes from excessive moisture bursting the skins, which nature attempting to repair results in scales.

Bermudas. 23. Q. Why are Bermuda potatoes always smooth.skinned?

A. Because grown on coral or lime soil, and because largely fertilized with sea weed, the salt and lime both being obnoxious to insects.

Potato Seed. The potato, as ordinarily propagated, is not grown from the seed, but from the tuber, a cutting of which resembles a graft or bud from a tree, and perpetuates the good or bad qualities of the parent. The true seed, which is borne in a seed-pod following the blossom, is very seldom seen, is very difficult to gather, and consequently is very expensive. In appearance resembles a tomato seed of about one-tenth development; the potato belonging to the tomato family. The seed germinates very easily, and the plants can be cultivated by any one, producing tubers the first year about the size of buckshot; these, planted the sccond year, double in bulk, and after about three or four years, become of edible sizc. As en. tirely new sorts are tluus produced, the cultivation is very interesting and often profitable. Per pkt. $30 \mathrm{c}$. 
We here record our protest against the expression "Irish potatoes" as applied to any of the many forms of round or kidney potatoes, the plant being a native American, found growing wild from Arizona to Chili.

New varieties of potatoes are alone derived from the true seed, which is obtained from the seed balls; these seed balls are generally borne upon late varieties. The development of new varieties of valuable qualities is tiresome and disappointing, as often ten years of labor may not bring a single truly valuable sort. It is, however, a matter of chance, and the first experiment may develop a novelty of the highest merit.

24. Q. What is the product of cucumbers?

Cucumbers.

A. For early use plant in hills $4 \times 4$ feet, on a warm border, when the cherry is in bloom, and for a succession sow in drills at five feet, when the apple is in bloom. For pickles plant middle of Summer.

In Florida and other Southern States, a fair average production per acre of slicing cucumbers is two hundred crates, $8 \times 14 \times 20$ inches. Some growers claim average crops of 400 and 500 -even 800 crates have been recorded, but these large yields are only occasionally heard of.

Fresh Southern cucumbers appear in Philadelphia the last of November, and command $\$ 1$ to $\$ 2$ per dozen. Towards Christmas the price rises to $\$ 2.50$ per dozen, after which the price declines to $\$ 4$ or $\$ 5$ per box of eighty-five to ninety fruit. By last of May the price goes down to $\$ 1$ per dozen, after which shipments are unprofitable. As a rule the early cucumbers from New Orleans bring better priccs than those from Florida, being better sorted and better packed.

A good crop of cucumbers, when gathered of pickling size, produces from 100 to 175 bushels to the acre. A bushel contains abont 300 pickles. Some cultivators have claimed to produce over 100,000 pickles to the acre. The pickles should be slipped from the vine by the thumb and finger without raising or disturbing the vine. The pickle houses generally pay the farmers forty to fifty cents per bushel, they in turn sell them at from twenty to thirty cents per 100.

Pickles properly prepared will keep five or six years. The method of salting pickles, as pursued in New Jersey, is as follows : To a cask of 120 gallons capacity, take four quarts of salt and mix in two gallons of water. Place the solution in the bottom of the cask and put in the green pickles after washing. To each two bushels of pickles put into the cask add four quarts of salt, and continue until cask is full. Place the head of the cask, with edges trimmed off to permit of a rise and fall, on the top of the pickles, and on the top of the head or lid place a weight of twenty or twenty-five pounds. If there should be any leakage of the liquor, replace it by a solution of four quarts of salt to two gallons of water, keeping all the pickles submerged. Salt should not be stinted. Pickle packers make three sizes before pickling-large, medium and small.

25. Q. What is the form of a Long Green Turkey cucumber?

A. A Long Green Turkey cucumber is long, three square and at the stem Cucumbers. end of a reduced diameter, the seed being found principally in the blossom 
end. In an ordinary "Long Green" the diameter is about the same throughout its length, and the seed found throughout a larger portion of the fruit. The Long Green Turkey is a light producer of seed, and conse. quently the seed is higher priced than other field varieties.

Pickles.

26. Q. Which variety of cucumber will produce the most small fruits for pickling?

A. The Short Prolifie and the Jersey pickle for commercial sales, but for domestic use the Long Green Turkey furnishes the best formed pickles.

Cucumber 27. Q. How shall I secure myself against the attacks of the cucumber Bug. or squash bug?

A. Start the plants in the house or under glass, the seeds planted in square pieces of sod for readiness of removal to the field when the leaves become half developed.

White Spine Cucumber.

\section{Slicing.}

Fruiting.

Cucumber

Crops.

Greenhouse Cucumber.
28. Q. What is a good White Spine cucumber?

A. It is a leading sort both in the private and market garden, appreciated by reason of its strong lealthy habit of vine and consequent productiveness, of deep green symmetrical fruit. If of a good strain the fruits are in length four or five times their diameter, and nearly of the same diameter throughout their entire length, slightly three-sided and dotted with small warts, from each of which springs an ivory-white thorn or spine, giving the name of White Spine to the variety. With a few exceptions other cucumbers bear brown or black spines.

From the extreme or blossom end of the white spine ten light-colored lines run towards the stem end, these lines as the fruit becomes larger turn bone white, sometimes a yellow white, and after the fruit becomes too old for shipment the entire fruit becomes a bone white, tinged with a light golden.

As a shipping variety the White Spine is highly prized, as it so long retains its green color, which, when it does change, alters not to a yellow, but to a less objectionable white.

29. Q. Which varieties of cucumber are the best for slicing?

A. White Spine, Early Frame and Long Green.

30. Q. Why do some varieties of cucumbers produce more fruit than others?

A. Because of a more perfect formation of flowers, and a more profuse distribution of pollen.

31. Q. Why do vine crops as cucumber and melons produce larger crops after a dry summer than after a wet one?

A. Because during the flowering period throughout a dry summer the pollen is freely carried from the male flowers by winds and insects to the female flowers, but during a wet season the pollen being made heavy by moisture it remains on the male flowers where it originates.

32. Q. In what way do English hothouse cucumbers differ from the usual American outdoor sorts?

A. The forcing-house varieties, as Rabley, Marquis of Lorne, Telegraph, are all more than twice as long as the longest field varieties, sometimes 
four times as long. They contain very few seeds, and are quite free from that property which to some people is so poisonous.

33. Q. How should I plant cantaloupes?

Cantaloupes.

Cantaloupes or citron melons, as they are termed in Jersey, do well upon sod ground or upon land prepared for planting by plowing down a crop of winter wheat or winter rye, the sod or grass aerating or leeping loose the soil.

The seed is planted at about corn-seeding time or when the apple is in bloom, in hills about four and a half feet in each direction. Two shovelsful of well-rotted stable manure being trampled into each hill and covered with earth. The large long melons, like the Reedland Giant and Casaba, are generally sold by the hundred; melons of the ordinary form and size are sold by the basket of one-half to five-eighths bushel capacity. Philadelphia commission merchants pay as a highest price $\$ 1.50$ to $\$ 2.00$ per bushel. As an average price forty to fifty cents per bushel. Cantaloupe melons are frequently a drug in the market.

34. Q. Why do some people use the word musk melon (corrupted to Musk Melon. mush melon) cantaloupe, nutmeg and citron, as applied to the same family of vine fruits?

A. (1). Musk melons as originally known were long, large-fruited, smooth-skinned, soft-fleshed, very aromatic and often of a sickening sweetness.

(2). Cantaloupes as at first distinguished were large, rough and irregular in form, often deeply ribbed and covered more or less with warts, the skin sometimes slightly netted, and at other times entirely without netting. Cantaloupes like musk melons are frequently inclined to crack at the ends.

(3). Citron melons are of a later introduction. In form, they vary from flat and round to ovoid, slightly ribbed, generally netted, the flesh perfumed, the seed small.

The term nutmeg was originally applied to citron melons of oval form Nutmeg. slightly larger at one end than the other, like the nutmeg of commerce. Among the New Jersey market gardeners the expression, cantaloupe or musk melon, is never used. They always speak of citrons.

35. Q. When should I plant watermelon seed?

A. When the black Walnut is in one-inch leaf, plant melons.

36. Q. How should I plant watermelons?

Seeding.

A. Watermelons do well upon sod ground or unon land prepared for their reception by plowing down a crop of winter wheat or winter rye, the sod or grain aerating or keeping loose the soil. When the apple is in bloom the seed is planted in hills at ten feet apart in each direction. Two large shovelfuls of well-rotted stable manure dug and trampled into each bill and covered with earth.

The cultivator shouid be prepared with quite four pounds of seed to the acre, that he may have a reserve for replanting in case of destruction of his plants by insect depredations or beating rains. 
One vine alone to the hill should be allowed to attain perfection; with four hundred and fifty hills to the acre, there should be nine hundred firstclass melons.

Philadelplia commission merchants pay for prime melons, as a highest price, forty dollars $(\$ 10.00)$ per hundred. As an average price, ten dollars $(\$ 10.00)$ per hundred. They cease to be profitable to the trucker when bringing less than four dollars $(\$ 4.00)$ per hundred. First-class melons are always in demand, but the market is frequently overstocked with small fruit.

Huch of the melon seed offered throughout the country is the product of immature and cleformed melons remaining in the field after all the choice fruit has been selected.

Watermelon. 37. Q. What constitutes a good watermelon?

A. If for shipping to market the requirements seem to be to obtain from the acre the greatest number of mammoth melons of good carrying quality, little regard being paid to texture of flesh, depth of color, or flavor, so that the flesh is solid and red. $\Lambda$ familiar example of a favorite shipping watermelon of only third-class quality is the Kolb Gem.

If for private or family use, the mammoth melons are not desirable, the requirements then being for those of fair weight, twenty to thirty pounds, flesh solid from centre to rind, the unedible portion being not more than one-half inch thick; color of flesh red, flavor sugary and texture so granulated or crystalline as to melt away like ice upon the tongue. A melon producing fruit of fibrous sponge-like nature, no matter what its other qualities may be, cannot be a first-class melon.

The Long Light Ieing, the Round Icing, Arkansas Traveler and the Boss are decidedly the best for the private garden.

Arkansas and

The Boss Watermelon.

Points of a good Citron Melon.

Foreign Cantaloupes. can-grown citrons?

A. Yes the seels of foreign sorts are inclined to turn up at one end, like a sled, are generally larger and nearly al ways more yellow. 
40. Q. To save my Citron or Cantaloupes from thieves ean I ripen them Ripening Citin the house? ron.

A. Yes; often better than in the field. Pull them when fully grown, wash them, dry them, and place them on shelres in a dry, warm room; soon an aroma will fill the room superior to that ever beforc noticed in the field.

41. Q. Why is it that my Montreal citrons, grown in Pennsylvania, do Flaror of not have the same flavor as those grown in Canada?

A. Because of the distinct conditions of growth. At Montreal the seed is sown in hotbeds, 20 th to 30 th of March. When the plants develop a rough leaf they are potted and three or four times pinclied back till about the middle of May, when they are set out in specially prepared hotbeds, three (3) plants to a sash. The glass is kept on till the vines fill the entire bed, when both the sash and frame are removed. Very little water is required, and when applied it is done without a rose, as it has been found injurious to wet the leaves.

42. Q. What is the merit of the netting or webhing on citron melons? Netting on

A. Strong webbing preserves a melon from the disfiguring effects of Citrons. abrasion, thus fitting it to withstand transportation better than the melons with smooth skins or only partial webbing. A strong netting often indicates a good flavor, but it is not the rule, for some foreign smoothskinned melons are hard to excel.

43. Q. Shall I shorten the long shoots of my watermelon vines?

A. Yes; pinch them back, cut them early before they get long.

Pinching

Back.

44. Q. Why do the full-grown vines of my watermelons, squashes, Melon Bug. and citrons get yellow and die off?

A. From injury by worms produced from the eggs of the squash bug which earlier in the season ate the young seedlings.

45. Q. How should an Orange watermelon be cut to the best effect ?

A. About an inch from each end slice off a slab so as to produce a flat surface and set the melon on end. With a knife, held so that one inch of the blade only can penetrate the rind, cut down the rind perpendicularly in lines one inch apart from top to bottom and pull it off, leav. ing standing the red flesh of the interior.

46. Q. What are the rules for determining when a watermelon is ripe? Picking

A. When a watermelon is ripe it has lost to a slight degree its lively Melons. green tint, appearing a little dull in color. At the stem cnd the curled wiry tendril has become quite dead. On the earth side the melon is well bleached and has become hard and woody.

The expert watermelon picker, however, is not guided by these outward signs, but relies upon the sound emitted from the melon when gently thumped with the back of the nail of thumb or fingers. A green, unripe melon responding with sonorous noise, while a ripe one, because of the spongy nature of the interior, sounds dull and heavy. Practice will soon make clear the difterence in sound. 
Radish. 47. Q. Why do my radish roots become rough and scaly?

A. Want of lime to drive off worms and grubs.

Tomatoes. 48. Q. How and when should Tomato seed be planted?

A. When the apple is in bloom sow in hills three feet apart, on a warm border, early in the Spring. For a later supply, sow a short time afterwards in a more open situation. As the plants advance in growth support them by brushwood. To have the tomato very early it is necessary to start the plants in a hotbed, or they may be reared in a flower-pot in a window and subsequently transplanted.

Plants for an early crop should be raised under glass. For intermediate crop they may be raised on outside beds. For late crops the seed may be planted in permanent position when the apple is in bloom. The aver. age production of fruit per acre on cultivated and fertilized land is about 14,000 pounds, or say 250 bushels per acre, though 18,000 or 20,000 pounds have been raised.

Southern Florida tomatoes reach Philadelphia in February, and command $\$ 4$ to $\$ 6$ per bushel. By April the rate declines to $\$ 3$ to $\$ 5$, and continues to decline till June, after which they fail to meet the cost of transportation. Forty to eighty cents per bushel is an average price, twenty-five to thirty-five cents per bushel for late crops. This crop ceases to be profitable to the trucker unless he can realize sixteen cents per bushel. They are very often a drug in the market. Tomato canning houses buy the fruit by the ton at from $\$ 6$ to $\$ 7$. For seed purposes alone we have washed out over 40,000 busbels of fruit in a single season.

Rough Sorts. 49. Q. Why is it that the rough-fruited tomatoes, Early Jersey and Richmond, are largely grown?

A. Because of their double qualities of earliness and resistance against transportation injuries.

By their earliness they are often more profitable than far better sorts subsequently put into market, and by reason of their hollow cells they will stand almost any amount of rough usage without bursting.

\section{Unfruitful}

Vine.

50. Q. Why do my tomatoes fail to produce either blossom or fruit?

A. Possibly by reason of the land being too richly manured or too much shaded.

Tomato Rot. 51. Q. Why do my tomatoes rot?

A. Possibly because of a fungus growth for which no positive remedy has been discovered. Some varieties are especially susceptible to it.

Spinach.
52. Q. Describe the difference between varieties of spinach?

A. The Bloomsdale is the earliest to develop plants of cutting size. Its leaves are entirely savoyed or bloated and it is accordingly the most elastic, bearing transportation better than any other sort. It is quite erect in habit, and in Spring shoots the earliest to seed. It is most valuable as an Autumn variety, being hardier than other sorts. The seed is round.

Prickly spinach has thorny seeds and is the second to develop to market size. The leaves are quite erect and elastic, somewhat similar to 
Bloomsdale. It is an excellent variety. The seed is thorny, hence its name.

Ever Ready is the darkest colored of all spinaches and slowest to shoot to seed; it is the best of the Long Standing sorts.

Flanders is the largest seeded of all the varieties. Leaves, spearshaped, on long, erect stems; it can thus be gathered generally free from sand; it is the third in order of maturity. Round Savoy is round seeded and round leaved, habit of growth not as erect as Blooms. dale, and not so much savoyed, the fourth in order of development to cutting size.

Viroflay, a mammoth-leaved variety, very showy, the fifth in order of maturity. Long Standing, the latest of all spinach to arrive at a cutting stage; leaves round on the edges, exceedingly deep green, leathery, inclined to lay flat on the earth, slow to shoot to seed, hence its name.

53. Q. When should cabbage seed be sown?

A. There is not a month in the year nor a day in the month when cabbage is not being sown in some of the gardening sections of the country. It is therefore impossible to name periods for sowing. That must be determined by the practice of each section. In a general way, however, it may be said that cabbage seed should be sown in February for an early Summer crop, and April or May for an Autumn crop, and in September and October for an early Spring crop. The seed is sown in rows of a foot apart, and after the plants reach a height of three or four inches they are pulled up and transplanted to permanent locations, where they are set in rows at three or four feet and at intervals of one-and-a-half to two feet in the row.

The question is of frequent occurrence : Why cannot private families have head cabbage as early as market gardeners? Simply because of imperfect culture and insufficient manuring. To produce a successful crop of cabbage the soil must naturally or artificially contain potash, phosphate, nitrogen. These are all found in good barnyard manure and in some commercial fertilizers. If these resources are not available, the potash can be had in kainit, the phosphoric acid in bone, or better, in superphosphate; the nitrogen in dried blood, meat or fish.

The market gardener feeds his cabbage crop wiтнотт stint and with the rankest food, frequently plows in the manure in the Autumn, turns it up in the Spring and thoroughly incorporates it with the soil; plants early, cultivates deeply, not simply tickling the surface with the hand. hoe, but uses the plow and horse-hoe; that cannot always be done in small family gardens, but the spade can be used, and that is the next best thing. Use it freely, dig deeply, and the result will surprise, those who have heretofore relied on the hoe alone.

Cabbages grown South for shipment in the Spring sometimes do not head uniformly, the result of checking by cold. The damage very frequently is not apparent till the heading season, when the crop appears to be a mixture of many sorts, some plants shooting to seed ; fields of difter- 
ent ages and different soil producing varying results. We recommend that an entire crop should not be planted at once, but set out at intervals of ten days. Cabbages on heavy hammock land are more injured by cold than on lighter soil.

Under good conditions and management about eighty per cent. of the plants in a cabbage field should, on an average, produce marketable heads, though sometimes ninety-five per cent. have been marketed. Market gardeners in Philadelphia, on an average, realize a net profit of about one cent per head. The pickle honses pay about $\$ 3$ per ton delivered at their factories.

Club Root. 54. Q. What is the cause of club root in my cabbage?

A. $\Lambda$ fungus growth superinduced by rauk manure or by constantly cropping the same land in cabbage.

Cabbage. 55. Q. Why do only half my cabbage produce good heads?

A. Not planted early enough. Given time all cabbages will head, unless mongrel sorts.

56. Q. What are the qualities going to constitute a good Wakefteld

Wakefield Cabbage. cabbage?

A. The head should be an obtuse or blunt-pointed cone, much the greatest diameter at the base. The leaves should extend up and above the apex of the head, to afford length for a perfect folding over and solid formation. The leaves should be close set, smooth, broad, even edged, and dark and leathery, and the leaf stem should be feathered to the joint. The dark leathery quality of the leaves is indicative of hardiness.

The stalk of a well-grown plant should be short, so that the head appears to almost rest upon the earth.

Early maturity and mammoth size are not found united in Wakefields any more than in any other plants.

Summer

Cabbage.

\section{Q. What constitutes a good Summer cabbage?}

A. Heads half or three quarters flat, the stems short, heads broad, deep and solic, leaves spoon-formed, color blue-green with marrow-like veins and completely crossing each other as they fold down over the head, which in the centre should be slightly rounded.

Late Cabbage 58. Q. What are the qualities constituting a good Late Flat Dutch cabbage?

A. This variety must be of a vigorous habit to develop the size most desired, the leaves must be broad, of a metallic blue green color, slightly fluted on the edge and folding clear over the centre of the head, which should be broad, deep and flat. The color of the leaves often indicates the order of maturity, the light-green plants being early, the deepest blue being late. There are probably a dozen forms of Late Flat Dutch, known by as many names-all cannot be the best, although some may be called Premium, others Matchless, others Superb.

Cabbage for 59. Q. Which is the best cabbage for late Autumn planting in the the South. Southern States for Spring markets?

$\Lambda$. The varieties best adapted are those of leathery leaves and dark- 
colored foliage, as such are the hardiest. Among them may be named, Select Early Jersey Wakefield, Early Market, Bloomsdale Early Dwarf Flat Dutch. The success attained depends however much upon the period of sowing the seed, the time of setting out, the condition of the plants as set out, and the condition of the Winter, as sometimes the influence of fluctuations in temperatures develop an abnormal tendency in plants to shoot to seed. It is a safe plau to sow seed and to set out plants at different periods.

60. Q. Why do not cabbage head?

A. Any passably fair stock of cabbage will always head if grown under proper conditions as rèspects period of planting, period of setting out, fertility of soil, and culture. The stock may be of many varieties, early and late, flat and round, smooth and savoyed, but they will all form some sort of heads if given time, provided they be not checked by some soil condi. tion. Collards or kale will not head, nor hybrids of the same, nor mongrel stocks of cabbage.

61. Q. How should peas be sown?

A. Peas are among the first seeds that may be sown at close of Winter, frequently being planted before sharp frosts are fully over. The drilling of peas may be safely commenced when the peach is in bloom and con. tinued at intervals up to within sixty days of frost for the early kinds, or seventy days for the intermediate varieties, or eighty days for the later sorts. Late sown peas are never as productive as those sown in the Spring, and often are found to be subject to mildew. Landreths' Extra Early will be found to be the best for August and September sowings, because of its early ripening habit and its ability to resist mildew. The dwarf varieties nay be drilled at $t$ wo feet if cultivated by horse power, or fifteen inclies if to be hoed by hand. The varieties of medium length should be drilled not closer than three feet, and the tall-growing sorts at five feet apart. The number of peas in a row may vary from ten to the foot in the case of the very dwarf kinds, to eight to the foot of the medium tall varieties, and six to the foot of the very tall kinds. Yield 100 to 300 bushels. At Philadelphia the highest average price paid by commission merchants for early peas is from $\$ 3.00$ to $\$ 4.00$ per bushel, and the highest price paid for late varieties is $\$ 1.50$ to $\$ 2.00$ per bushel, while the price sometimes is as low as fifty to thirty cents per bushel. Early peas are not grown profitably at less than fifty cents per bushel, nor late peas at less than forty cents per bushel. The pea thrives best in light, loamy soil ; the early and dwarf sorts demand rich ground.

62. Q. Does the boring of peas and beans by the weevil affect the ger-Pea Weevil. mination of the seed?

A. There will be a failure to sprout if the grub of the weevil devours the germ, but if the germ, is not eaten the seed will sprout.

Under favorable conditions of soil, moisture and heat, bug-eaten peas and beans, when the germ is not destroyed, will do about as well as un. injured seed, but under unfavorable conditions, when the young plant 
depends largely for its support upon the store of food laid upon the seed, any reduction in this store of food tends to make the plant weak and puny.

sowing Peas. 63. Q. When sowing peas in rows, how many seeds should be placed to the foot?

A. It is bad policy to save seed at the possible risk of a crop, for insects or excessive rainfall or no rain whatever may prevent the development of healthy plants. It is best to sow four seeds to the inch. The growing plants to be afterward pulled out or cut out to two plants to the inch.

Beans. 64. Q. What is the proper time to plant garden beans?

A. Sow when the apple is in bloom, and repeat as frequently as necessary till within fifty days of frost. In field culture sow in drills at two and a half feet apart. In garden culture, when the cultivating is done by hand, the rows may be at eighteen inches. The seed should be sown in such quantity as under ordinary circumstances to warrant one bean vine to every four inches. If closer than this their production will be impaired. On strong soil they do best at a greater distance. Yield about 75 to 80 bushels. Florida and Mobile beans reach Philadelphia from November till March; those shipments in January command from $\$ 5$ to $\$ 7$ per crate. Round-podded varieties are most in demand. Beans generally sell well, but by first of April decline to $\$ 3$ to $\$ 5$ per crate, and sub. sequently fall lower by reason of injury in transportation.

Soil 65. Q. How deep should seeds be covered?

Covering. A. As a rule seeds should not be covered over four (4) times their diameter, and when the soil is heavy seldom to that depth.

Beans, form 66. Q. What is the advantage of a round or cylindrical-podded bean of Pods. over a flat-podded variety?

A. The round is always more brittle, less stringy, and contains more flesh under the same amount of cuticle.

\section{Planting}

Lima Beans.

67. Q. How shall I plant my Lima beans, on side or flat, eyes down or up?

Distance.

A. Eyes down.

68. Q. How far apart should Lima bean poles be set?

A. Four by four feet if in a patch, or if in a single row then every three feet. Wire netting three to four feet high and supported by posts is better.

Bean,

Runners.

69. Q. What is a runner among bush beans or peas?

A. It is a plant which develops a long vine, and as such stands out in marked contrast among the other vines which are of uniform height.

Runners.

70. Q. Are all tall growing vines of peas and bush beans runners?

A. No. As often a vine situated over a lump of manure will run from extra fertility -or deeply-rooted vines will continue in growth after all others have stopped.

Bean Rust. 71. Q. Why do wax-podded beans rust more than green-podded varieties?

A. Rust, so called, is the result of a fungus growth, which seems to 
flourish to a greater extent on wax-podded beans than on the old greenpodded and less juicy and less delicate forms.

72. Q. What is a string bean?

A. It should be in its best estate a bean without a string, properly a suap short, but few sorts are perfectly stringless.

73. Q. How should sugar peas be prepared for cooking?

A. Break off the ends, pull off the strings, and then break up the pods into pieces half an inch long; cook same as string beans.

74. Q. Can you explain why my spinach for two years back has been so Spinach. sickly as to be of little value?

A. It must be suffering from insects at the root or from one of the three or four fungus growths known as spinach blight. If so, the only remedy is a change of location of the spinach patch.

75. Q. Does the color of the leaves of beets indicate the color of the flesh Beets. of the roots?

A. No ; the leaves of Long Blood beet, as generally sold, is quite oneSugar Peas.

third dashed with green. When selected entirely of deep red foliage, the production of seed is so reduced as to be unprofitable.

76. Q. How many tons to the acre of sugar beets are grown on the beet Sugar Beets. farmis of Germany?

A. Twenty to thirty tons.

77. Q. What percentage of sugar is obtained from the German sugar Beet Sugar. beets?

A. Many years ago only five per cent. as the result of actual manufacture; now ten and sometimes fourteen tons of sugar from one hundred tons of beets.

78. Q. What are Mangold Wurzels?

Mangolds.

A. A family of beets bred to a large size for cattle feeding. The roots are easily injured by Autumn frosts, and therefore must be taken up in good time and properly protected. When first harvested they are acrid and scour cattle, but after a few months become palatable and safe. The approved types produce massive roots which, well elevated above the surface, are harvested with the greatest ease and produce double the weight of turnips to the acre, to which advantage may be added the high nutritive value, the saccharine often being equal to six or seven per cent. of the gross weight. The Mangold is a high feeder-potash and nitrogen are needed to force the plant into vigorous growth; stable manure will do it, or kainit mixed with dried meat or fish. Drill when the cherry is in bloom.

79. Q. What should be done with the weeds when pulled up ?

Weeds.

A. They may be burned and the ashes used as manure. They may be used in the formation of compost piles if their seeds are immature, or they may be put in cattle yards to be trampled down.

80. Q. What is the best manure?

A. "Landreths' Farm Notes" says stable manure is king, but it cannot always be obtained in quantity, nor at the desired periods; failing to 
obtain it for present use, we recommend chemical manures, which, used in seasons not too dry, may do equally well at less cost; but if time permits, green manures will be found the cleapest.

Green

Manures.

Corn.

Sugar Corn.
81. Q. How is green manuring practiced?

A. Four crops of green manure can be turned down in seventeen months, by seeding rye in October, corn in April, a second crop of corn in July, and rye again in October, to be plowed under in April. This rotation will surprise the experimenter, who will see his soil made fertile, friable, and in general vigor far beyond its previous condition, all due to the valuable component parts of the vegetable matter plowed under, and to the absorption and retention of nitrogen by the soil consequent upon the extended covering of the surface. From the earliest agricultural rec. ords green manuring has been practiced, and whole districts of country in Europe have been rendered fertile by such practice. A large district in Germany, once a barren, is now most fertile, all due to the use of the lupine, which plant, however, does not offer such good results under the hot sun of the American climate.

82. Q. What is the history of Corn or Maize?

A. This is a native of North and South America, having been found in cultivation by the first European voyagers. Modern researches in Peru and Mexico have given evidence that its culture extends far beyond any historic period. There is no foundation whatever for the statement that Indian corn has been found in the wrappings of Egyptian mummies; such tales being pure fabrications. Seeds of wheat, sorghum and millet have been discovered, but it is doubtful if any suclı seed ever vegetated. Indian corn may be divided into six classes, viz.: Pop, Zea Everta; Flint, Zea Indurata; Dent, Zea Indentata; Soft, Zea Anylaca; Sweet, Zea Saccharatum; Pod or Husk, Zea Vaginata; and each of these are subdivided according to shape of the ear, number of rows upon each ear.

83. Q. Give directions for planting sugar corn.

A. Table corn cannot be planted successfully at an earlier date than the ordinary field varieties, indeed it is more likely to decay under unfavorable soil conditions than the hardier field varieties. As a rule, sugar corn is not as vital as the field sorts, and therefore it is wise to plant almost a double number of grains in the hill as compared with ficld corn. When the cherry is in bloom, hills for the short varieties of three and four feet in height, may be made three by three feet apart ; for the intermediate varieties three by four feet; and for the tall varieties, four by four feet apart. In all cases allowing three stalks to stand to the hill. Repetitions of corn planting slould be made every two weeks, and for the quick-ripening varieties the planting may be continued until within sixty days of frost. Seed should be provided at the rate of ten quarts to the acre. We always provide that much, though often only planting six or seven quarts. The plants thinned out to three inches apart. Of the medium and large varieties of sugar corn seventy-five to eighty bushels, or 8000 to 9000 roasting ears can be had to the acre. The average price paid 
by Philadelphia commission merchants is one dollar per bushel. The highest price is about three dollars per bushel and the lowest price about sixty cents per bushel. Green corn packed loosely in slatted bushel baskets will, in early season, carry safely for forty hours. In larger packages it may become injured by heating. Caution. - Seed corn in bulk should be taken out of the bags as soon as received and spread out in a dry place.

84. Q. IIow many varieties of corn are there?

Corn.

A. Indian corn as a family may be divided into six divisions : as-pop, flint, dent, soft, sweet, and pod or primitive.

85. Q. I have a variety of corn, many etalks of which are bearing threc seed Corn. large ears, and I write to inquire, if I take my seed for next year from the stalks bearing three ears will the next crop also bear three ears?

A. There is no assurance that corn grown from ears of which there. were three on a stalk will reproduce that same character. There is, however, a strong probability, and were it not for the disposition of heredity in plants of all kinds, there would be no encouragement whatever for the farmer to endeavor to improve by selection.

86. Q. Why is it that sugar corn is often weak in germinating force?

A. Sugar corn is among the most delicate of all seeds to cure and keep in good condition. If kept over Winter in sacks it will often lose half its vitality from heating or sweating. It should accordingly be kept spread Storage. out upon floors or trays in a dry cool place.

87. Q. How should a vegetable garden be laid out?

A. The old style of garden, laid out in squares to be dug and culti. vated cxclusively by hand, is becoming a thing of the past. 'The vegetable garden is now laid out in parallel rows or drills, ranging from two to three feet apart, and the cultivation in the greater part done by horsepower. The seeds should be all sown in drills or rows so as to be adapted to horse culture; hand labor is the dearest of all and should be avoiùed. The land, if circumstances will permit, should not be of a less length than seventy-five yards, and may with advantage be extended to two hundred, according to the quantity of vegetables required. Long lands where animal power is used are much to be preferred to short fields, as much time is saved in turning; for example, a plow team in a journey of eight hours, plowing land seventy -eight yards long, spends four hours and thirty-nine minutes on the headlands, whereas were the furrows two hundred and seventy-four yards long, the time spent in turning would be but one hour and nineteen minutes. The tillage of the garden should be with the most approved labor-saving implements-wheel-hoes, for hand use, scarifiers and cultivators for horse ; the seeds should be sown with hand-drills, and fertilizers of the guano class applied with similar apparatus, and thus, without interfering with the labor of the farm, be made to yield vegetables in profusion, when if the spade and hoe be relied on they are produced in stinted quantities.

The amateur gardener, and the expert as well, should make out a list of the varieties of vegetables he desires to have, and then lay off on paper 
a diagram of his garden, assigning certain rows to each sort. He can then readily calculate the amount of seed he will require.

Turnip. $\quad 88$. Q. What is a strap-leaved turnip?

A. A strap leaf is an entire leaf, differing from a cut leaf which is serrated clear through to the midrib, while on strap leaves there are no indentations, but the edges form an unbroken line like the margin of a rabbit's ear.

Celery. 89. Q. Will a good type of celery ever produce pithy stalks ?

A. Yes, sometimes it will on light soils.

IIost 90. Q. Which celery is the most profitable?

Profitable. A. Opinions differ, but all unite in advocating the culture of the short varieties, as they are more easily managed than the bulky sorts. The red varieties are more hardy than the white and more effective.

Roots 91. Q. How can I keep my root crops of turnips and beets throughout Keeping over the Winter?

Winter.

A. Crops of turnips, beets, carrots, parsnips, salsify, potatoes, can all be kept by pitting. Mounds as sometimes used are more exposed to frost and require careful construction.

When pitting select a suitable spot protected by buildings or forest from the severity of winds and where the drainage is good, an indispensable prerequisite. Dig a trench sixteen inches wide and as many or more inches in depth, the length as convenient or necessary, the trench divided into sections with undisturbed earth partitions every ten feet, to arrest fermentation occurring in any one division from passing further to the next. In this trench deposit the topped roots to a quantity raising them almost even with the surface and cover with the earth dug out of the trench, banking it up to a height of twelve or fifteen inches. When frost may be expected in severity cover the bank with long stable manure or trash. Roots of all descriptions can thus be kept securely. They are accessible at all times and may be removed as needed. In pits such as described, the writer has kept beets and carrots for caltle feeding up to the first day of July.

Horse-radish 92. Q. How should horse-radish be planted?

A. This plant, seldom producing seed, is propagated from sets cut from old roots, aud in market-garden culture nearly always planted as a succession to a Spring crop which by time of removal leaves the horse-radish well established. The sets are planted in rows of about two feet by eighteen inches, frequently among Spring cabbage. Holes are made with a long planting st:ck, into which are dropped the horse-radish sets to a depth that the top will be three inches under the surface. It will only succeed in highly fertilized land, and each year should be planted afresh. In garden culture the sets are sometimes planted in the upper end of round drain tiles sunk into the ground and filled with earth, the radish root being thus directed straight downwards. Yield about 150 bushels to the acre. Sets, per doz. 15c.; per 100 50c.; per $1000 \$ 4.00$.

Garden 93. Q. Will it pay me to engage a practical trucker to oversee my marMauager. ket-garden farms? 
A. Yes, if the farm is of ten or more acres.

Length of

94. Q. Do you recommend long or short rows for vegetable garden kows. culture?

A. Long lands, where animal power is used, are mucl to be preferred to short fields, as much time is saved in turning; for example, a plow team in a journey of eight hours, plowing land seventy-eiglit yards long, spends four hours and thirty-nine minutes on the headlands, whereas, were the furrows two hundred and seventy-four yards long, the time spent in turning would be but one hour and nineteen minutes.

95. Q. Is amateur or market gardening a business easily learned?

A. To raise ordinary vegetables not much experience is necessary, but

a complete knowledge of the art of gardening can only be acquired by much experience and quick perception.

96. Q. How should I make a lawn.

A. The Landreth lawn grass mixture which we offer should not be compared with the cheaper preparations advertised. Our prescription is of the best cliosen varieties, as respects color, texture and permanency, and will be found clear of weed seeds. Any one who purchases cheap, badly mixed lawn grass will soon realize that it was a poor investment, as the error will stand out for years in glaring ugliness.

This prescription consists of 100 parts, divided in such proportion be. tween those grasses which our observation has indicated as best for general park effect, as respects color, density of herbage, vigor, quick recuperation after mowing art pernianency. The seeds used are all well cleaned, and we believe them to be pure and of full vitality, and all persons using them are certain to secure a stand, provided the land be properly prepared and the seed sown at the proper time and at the right depth, and provided there be sufficient rainfall to germinate the seed. We cannot be responsible for the errors of the inexperienced. A pound of seed will sow a space $20 \times 20$ feet, or say 400 square feet. Sixty pounds will sow an acre, but we recommend seventy or eighty pounds. Price per pound, about 25 cents.

Much of the success of lawn making depends upon the preparation of the ground. The land must be well plowed or dug and harrowed or raked to secure thorough pulverization, and after being reduced to a perfectly even surface should be cleared of stumps, stones, roots and other impediments. The soil should then be made firm with a heavy roller and top-dressed with a good fertilizer, unless the land had received an application of seven to eight tons of very short well-rotted stable manure before plowing. The will here remark that stable manure is the best of all fertilizers, but there being some difficulty in obtaining it and objections to its use on account of its offensive appearance and smell, we recommend in Landreth lawn fertilizer a good grade of concentrated fertilizer. Six to seven hundred pounds to the acre of such mixture should be applied. The fertilizer should be lightly harrowed in upon the seedbed, as it will be lost to the young plants if buried much beneath the surface. After 
the harrowing the ground should be severely rolled, that the earth and seed may be brought into close contact. Our lawn grass mixture should be sown at the rate of sixty pounds to the acre and rolled down. Sowing in September and October will be found most advantageous in latitudes south of Philadelphis; in more northerly locations Spring sowing is most successfully practiced, the work being done in April and May.

Annual seeds, natural to the soil, are certain to spring up before the young grass becomes established, and an inexperienced person is likely to conclude that the weeds spring from weed seed in the grass seed, but all soils contain weed seeds, and upon tillage they are certain to vegetate. The weeds as they become large enough may be eut down or pulled up; after the first year their growth will cease. Frequent rolling is advantageous in producing a good lawn by solidifying the soil, harassing insects and other vermin, and improving the level of the surface.

Students of agriculture will find the volume on the "Grasses of North America," by Professor W. J. Beale, of much value in assisting them in this interesting study.

On all lawns will regularly appear in greater or less numbers a lot of interlopers, such as buttercups, plantains, dandelions, all from seeds natural to the soil. These uninvited guests should always be dug out, otherwise subsequent labor will be increased one hundredfold by their seeding. Lawns may be advantageously dressed with stable manure in December, the long strawy portions being removed in March.

On those portions of lawns as around the house, where an immediate result in grass effect is desired, sod may be used. Fair sod can generally be had on roadsides, and if carefully taken up and when laid down accu. rately jointed and solidified, and covered with half an inch of rich compost, it will at once start off and very soon be as much a fixture as the adjoining trees and shrubs.

Lawn grass of good quality should produce a fair mat of herbage in from seventy to ninety days.

Some parties offering lawn grass at a low price are using the so-called Canada Blue Grass, which sometimes contains seeds of Canada Thistle, a pest, and difficult to eraclicate.

Some people, after seeding a piece of land with lawn grass expect to see a green mat in two or three weeks, but in this they are unreasonable, as the better varieties of grass are slow to produce effect, and when an effect is quickly developed it is at the expense of adaptability and permanency. For instance, a fine mat of green color can be had in two weeks from a heavy sowing of white clover, something very effective and pleasing to the eye, but clover is not a grass and is not suitable for lawns, failing to produce that velvet-like effect, the result of the growth of the erect leaves produced by the best grasses, which habit fits them to quickly recover after mowing.

Manures or fertilizers for lawns may be of many combinations. We recommend to those who prefer to do their own mixing a compound of 
300 pounds of superphosphate, costing say.......\$5 00

300 pounds dried meat, blood or fish, at ........ 600

400 pounds refuse common salt, at .......... 100

Or say per acre $\ldots \ldots \ldots \ldots \ldots \ldots \ldots \ldots \ldots \overline{\$ 1200}$

The quantity of the two first may be doubled to advantage, or even made stronger, as grass will stand almost any amount of fertilizer.

The common salt used as an alterative and solvent will be found, through its affinity for moisture, to have a decided influence in keeping up the emerald green condition so desirable on a perfect lawn. On grow. ing grass not more than three bushels to the acre should be applied in a season, and then best during a rain-never under a hot sun.

97. Q. What kind of grass should be sown on athletic grounds ?

A. This prescription is also of 100 parts, but differs from our park lawn Athletic

grass in the list of varieties, a proportion of such sorts being here added as to better stand the wear and tear of tramping consequent upon games of tennis, cricket, lacrosse and baseball.

A pound will sow a space $20 \times 20$ feet, or say 400 square feet. Sixty pounds will sow an acre, but we recommend seventy or eighty pounds. Price per pound, 25 cents.

Old lawns much in decay had best be plowed up, leveled up and resown, but often this course is not convenient, certainly not if the lawn can be renovated by a system taking less time. In that case, when prompt results are desirable, the old sod should be well combed by a harrow to tear out the dried grass and easily extracted dead roots. This operation also breaks the earth, putting it in a pulverized condition to reeeive seed, which may be sown broadcast, and falling between the living grass, roots into the friable and fresh soil, and is at once in position to germinate and occupy the space. On many lawns eut with the lawn mower there ap. pear many pests-the creeping veronica and the mouse-eared chickweed being prominent-which crowd out desirable grasses and mar the appearance of the sward. Under such circunstances it is advised to break up the parts affected and sow with seed of the Sheep Fescue, which will admit of such close cutting as to destroy all pestiferous plants. The seed of Sheep Fescue costs about sixteen cents per pound.

98. Q. Is there a grass or mixture suitable for growth under trees? Grass under

A. Landreths' mixture of varieties produces a reliable stand under Trees. dense shade of either pine or hard-wood trees in positions where all other grasses may have failed. Sixty pounds should be sown to the acre -or, say one pound on a space $20 \times 20$ feet, or in proportion for other dimensions. Price per pound, 25 cents.

99. Q. What is the best grass for a permanent pasture? A. The preparation of the laud for permanent pasture is a labor that
must not be slighted, and though farm work cannot be reduced to the Permanent nicety of lawn eulture, we nevertheless direct attention to our directions on lawn making, and would say that the nearer the directions are fol- 
lowed the greater the probability of success. It must, however, be borne in mind that a pasture sod cannot be obtained in one year.

The judicious selection of grass seed for the creation of a durable pasture requires a knowledge obtained only by an intimate study of the habits of varieties as respects quality of herbage and vigor of constitution. Except in the Blue Grass sections of Kentucky and Tennessee, it is not suffieient always to select the one grass indigenous to the district, for it may not possess the double quality desirable for green pasturage and lay, for hardiness and permanence, which combination of qualities and character is best found in a mixture of sorts. That prescription, to be thoroughly scientific, should be adapted to the geological composition of the soil, be it slaty, calcarcous or alkaline, as well as the mechanical condition of the soil, be it sandy, loamy or clayey. These conditions vary so much that no one can attempt to be entirely exact in a recommendation for grasses to be planted. We cannot more than undertake to prescribe for soils heavy, as clay or deep loam; medium, as light loam or peat; light, as sand, slate or gravel. We are prepared to furnish single grasses, or two or three in a mixture, to meet the requirements of any ordinary farm land for the production of hay ; or, if permanent pasture is desired, we are prepared to furnish mixtures for soils either beavy or light.

Hay Grasses. 100. Q. I should be pleased to have your views in regard to grasses for hay and pasture for our Texas stock?

A. Most artificial grasses fail to stand in warm climates; even in tide. water Virginia there is difficulty.

Natural grasses, when good ones can be found, are to be decidedly preferred. Attention is however invited to Orchard grass as a vigorous and generally reliable sort.

Alfalfa is a grass resisting heat. When once established it is a heavy produeer, but does better as a grass to be mowed than pastured, as cattle eat off a large portion of the crowns which stand up above the surface.

Red Top, 101. Q. What is the distinction between Herds grass or Red Top, and or Finde Island Rhode Island Bent?

Bent.

A. Herds grass, growing very largely in New Jersey and the West, is known botanically as Agrostis vulgaris. Rhode Island Bent, found growing naturally over the States of Connecticut, Rhode Island and Massachusetts, is known as Agrostis vulgaris minor. They are very similar in nearly all particulars. The Rhode Island Bent, when kept mowed down closely, makes a fine lawn effect; no other variety of grass being more highly prized, for lawn purposes, in the New England States.

Canada Blue

102. Q. What do you know about Canadian Blue grass?

Grass.

A. Blue grass seed from Canada was sold in the Eastern markets forty or fifty years ago in preference to the Kentucky seed, because the latter was fuzzy and not easily sown. But later on, by the use of improved machinery, the Kentucky seed was made as clean and free from fuzz as the Canadian, and is preferred to the latter as being purer and free from any danger of Canada thistle, which is the worst pest which can establish itself upon a farm. 
103. Q. Why is it my new lawn sowed with lawn grass is full of weeds? Lawn Grass.

A. From seeds of weeds, some of which may have been in the soil for many years. Every experienced gardener knows that in nerv lawns weeds always seem to take possession of the land. They should be pulled up or mowed off. If the seed of the lawn grass is vital, patience will reward the gardener. The weeds are only annual and will die during Winter whilst the grass will live.

104. Q. Why do some lawn grass mixtures develop an earlier effect Cheap Grass. than others?

A. Those which produce the earliest effect are generally combinations of the cheaper grasses, prominent among which is Herds grass.

105. Q. Should hay be cut before it is perfectly ripe?

IIay.

A. Yes, because in the unripe forage there is considerable sugary matter most valuable in cattle feeding, which as the plants ripen changes first into starch and then into woody fibre.

106. Q. What is your experience with Scarlet clover?

A. Our field experience with Scarlet or Crimson clover, as it is variously Clover. called, dates back to 1871 , when we first grew it as a field crop on our Virginia farm. Many years before that we grew it experimentally in our trial grounds. Its value is :

(1). For pasturage in Winter and early Spring. If not pastured too clnsely it will afterwards make a crop for cutting for green feeding, later on for hay, or still later for plowing under.

(2). For cutting green in April and May as food for horses or cows; soiling as it is termed. It will be found fully four to five weeks earlier than lied clover, consequently it admits of very early cutting. The New Jersey Experimental Station estimates that one acre in April and May will feed ten cows for twenty days. In New Jersey fifteen tons of green stuff has been cut to the acre. Its composition and digestibility is better than Red clover, but of course animals must not be permitted to overfeed.

(3). For hay. In dry hay it gives a product of one to two tons to the acre of a quality similar to Red clover. The stems, when the crop is in bloom, vary from two to five feet long according to soil.

(4). For green manuring. This may be done in April or May and is its chief merit because of its wonderful development by that date both above and below ground. Like Red clover it roots to great depths, even as much as six feet, and gathers the spread-out potash of the soil, drawing it up and concentrating it near the surface, where subsequent and less deeply-rooting crops can get it.

The New Jersey Experimental Station estimates its value in potash and nitrogen at thirty dollars to the acre. Of course this is a laboratory test and a book-maker's calculation, but the field experience of hundreds of observant farmers seems to sustain the estimate as the result of plowing it under. In Jersey, Maryland and Delaware, where it is best known, the results have been phenomenal. It will not flourish on wet land, but it will grow on poor, sandy soil or on thin, worn-out lands, but Soil. 
of course naturally does better as the soil improves. Its effect is most noticeable on worn-out fields and we specially recommend it to the owners of such in cotton and tobacco sections.

Seeding.

North of the Potomac and the Ohio rivers it should be sown between 1st July and 15 th August. South of that latitude it can be sown in September and October according to latitude. Fifteen pounds should be broadcasted to the acre : the land well-plowed aud harrowed before and after geeding. It should be very lightly covered. It does not do well sown with grain, as it cannot be cut green nor pastured when among grain, while for plowing under it needs to be turned down before the grain is ripe. It can be sown to great advantage in apple, pear and peach orchards after the tillage has ceased. Its manurial eftect upon peach trees is very remarkable. It can also be broadcasted with buckwheat or sown among fields of tomatoes, melons, corn and cabbage, or any crop where the culture is over by the first of September, the clover to remain after the named crops are removed. Growing more rapidly than Red clover, it develops before Winter a mat-like covering over the ground, protecting it from the injurious effects of exposure to wind and sun during Winter. In this respect it is better than rye, because it is equally quick and more fertilizing, being a potash plant. Sown in such places as indicated, it can be plowed down any time in the Spring to a profit four times its cost.

Cost.

The cost of seed to sow an acre is about $\$ 1.00$ to $\$ 1.50$. The expenses of preparing the land to sow and plowing the clover under can be calcu. lated by any farmer. The estimated value to the acre of Scarlet clover as a green manure is thirty dollars. An experiment conducted with a corn crop following a crop of Crimson clover, the seed of which costs one dollar to the acre, and the various operations of plowing and harrowing four dollars-a total of five dollars-gave as much corn to the acre as an application of twenty dollars' worth of nitrate of soda.

Cutting Grain.

Plant Foliage.

Dodder.
107. Q. Should wheat, rye and oats be cut before fully ripe?

A. Yes, as by such course the straw is of a better quality, there is an extended opportunity to secure the crop, there is a saving in the crop by securing it all, and the nutritive powers of the grain are greater than when longer exposed to the action of the sun.

108. Q. Does the outward appearance of plants indicate the character of manuring and system of tillage necessary to be pursued?

A. Decidedly so. Beans and peas show by their foliage that they derive most nutrition from the air, and wheat and rye from the spareness of their foliage show they receive the least.

109. Q. What is dodder?

A. It is a parasitic creeper, leafless, twining, the stems twisting contrary to the sun's course and attaching themselves to the supporting plant by numerous air roots which, extracting the sap of the plant, kill it by starvation. The seeds of dodder at first germinate and vegetate upon the earth till the plant reaches a height of two or three inclies, by which 
time, if its tendrils can seize upon the juicy stems of clover, flax, hops, tomatoes, onions and many other plants, they will attach themselves to these plants and ceasc to continue their attachment to the soil. The color of the plant is yellow, and it produces closely packed heads of bellshaped white and pink flowers sometimes quite sweet scented.

110. Q. What is ramie?

A. It is a plant, a native of China and adjacent countries, and of value as producing a bark containing a fibre in many respects supposed to be equal to fiax.

111. Q. In what States can ramie be grown?

A. Very successfully in any of the cotton States. The roots once planted last for many years.

112. Q. How many tons of the dry green bark can be produced to the Green Bark. acre and at what value?

A. On good bottom land two to three crops can be grown. To each cutting from 500 to 1000 pounds, worth five cents per pound.

113. Q. Has the manufacture of ramie fabric yet become an established Manufacture. process?

A. Not yet, though many mills are making experiments in de-gumming imported ramie bark known as China grass and in spinning the thread and weaving tissues.

114. Q. Give directions for starting or forcing Vegetable or Flower Forcing seeds in the house?

A. When it is desired to hasten the development of plants, they may be sown in the conservatory or in boxes within the house. Those who have greenhouses hardly need directions, but for those who have had less experience we drop the following hints :

Procure shallow boxes, trays, or broad pots from two to four inches deep; the bottoms permitting the free passage of water, else the earth will bake and become sour. Seeds will not germinate satisfactorily or thrive in a wet soil. Prepare a mixture of one-third leaf-mold cut fine, one-third clean sand, and one-third finely pulverized stable manure; moisten the mixture thoroughly, and fill into the boxes to within a half inch of the top-gently patting down the surface to a level. Upon this distribute the seed, and cover just out of sight, by sifting over the seed the finest eartl procurable, settling the seed down with a fine spray of water shaken from a brush, a heavier application baking the surfuce. Place the boxes where they will remuin at a temperature of between $60^{\circ}$ and 700 , applying water with a brush or fine rose when the surface becomes dry. When the seedlings are half an inch high, they may be transplanted to other boxes, placing the tiny plants about one to each square inch. When these become so large as to crowd each other, they should again be transplanted to the garden or to other boxes according to the season.

115. Q. What is a hotbed?

A. It is a box or frame without bottom or top, made for one, two or 
four sasli, as in the illustration. It may be made permanent of brick or stone, or temporary of plank or one-inch common boards, the back board about twenty inches high, one-half greater elevation than the front, which should be twelve to fourteen in $\mathrm{ch}$ es - the whole made to support a sash

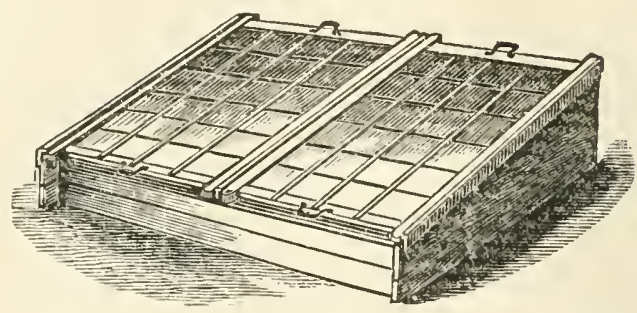
or several of any dimensions, the best of about three by seven feet. The back being higher than the front, gives a declivity to the sash, thus casting off the rain, which it would not do if flat.

The box at proper season is placed upon a bed of fermenting material, which, making a gentle and continuous heat, warms up a layer of soil resting upon it, and thus germinates seed and forces plants into rapid growth.

Manure.

The value of the bed depends principally upon the cliaracter of the fermenting material. This should be rich stable manure (no cow dung) forked over two or three times at intervals of a week and kept in a deep and compact pile till it begins to smoke or steam, indicating that the process of fermentation has set in. If the dung be very rich in grain an addition of forest leaves is desirable, as they serve to prolong the period of fermentation, which otherwise might be too rapid.

Location and Selecting a well-drained location, and one never flooded by rain, excaMaking. vate a pit one or two feet deep, and one foot longer and one foot broader than the box. Into this place six inches of rough barnyard manure, corn stalks, leaves or straw, for drainage, and on it lightly fork in the ferment. ing dung and tramp it firmly down to a depth of two feet. Place on the box and fit the sash lightly, cover with mats and allow fermentation to again proceed, banking up with hot manure on the outside all around at an angle of $45^{\circ}$. Place on top of the manure a layer of three inches of rich, moist, finely pulverized soil. In a day or so the temperature will rise to $120^{\circ}$. When the temperature has fallen to $90^{\circ}$ destroy all the weeds which have sprouted; and sow the seed for which the bed is in. tended. Cover every night with mats to exclude frost and give air during the day, never allowing the temperature to fall below $70^{\circ}$ or rise above 900 . The secret of growing good plants is to give plenty of air, else the plants will be sickly, spindly specimens. Short, stocky plants are what are desired. Sow the seed in rows three inches apart and one-quarter to one-third inch deep, and cover by sifting on fine earth.

Care of Hotbeds.

Water every evening. Remove the mats every morning about nine o'clock, give air about ten o'clock. Cut off the air in the afternoon as soon as the air becomes the least chilly. Cover with mats before sunset. Hotbeds should be covered early in the evening, to retain their heat, and 
in the morning uncovered when the sun rests upon the glass, as every effort should be made to give the plants all the sunlight possible, as its rays are vivifying to a degree beyond the amount of its heat, it having a chemical and physiological effect beyond explanation. Even dull light is better than no light, consequently it is a bad plan to cover sashes with mats, except for the direct purpose of keeping out cold. Peppers and egg plants require more heat than other plants. Success depends on bottom heat from the manure, top heat from the sun, water from daily application, and air at midday. Without plenty of air the other requisites will be fruitless. All seedlings should be transplanted into other hobteds or intermediate beds when two inches high. Hotbeds may be used for forcing lettuce, radish, egg plant, pepper, tomatoes, cabbage, cauliflower and ornamental flowers.

We have known locations where stable manure for hotbeds was not Artiflcial readily obtained, and to meet such conditions we give the following Heat. directions for manufacturing a fermenting material for the production of a moderate and continuous heat, the quantities named being sufficient for a box twelve by seven feet. Take as the crude materials, 500 pounds of straw, three bushels powdered quicklime, six pounds muriatic acid, six pounds saltpetre.

Having prepared the excavation of proper dimensions, spread three or four inches of forest leaves or old hay in the bottom. Upon that spread eight inches of the straw, tramp it down and sprinkle with one-third part of the quicklime. Dilute the six pounds of muriatic acid with twenty gallons of water, and by means of an old broom, sprinkle the bed with one-third part of the solution. Make another layer of eight inches of straw, applying quicklime and the solution as before. Repeat for a third layer. Upon this make a fourth layer of straw, and upon it sprinkle the four pounds of saltpetre dissolved in thirty gallons of water. Place the box in position, bank up outside, within the box spread three inches rich, finely pulverized earth, and put on the sash. A heat will soon be generated which will continue for two or three weeks.

116. Q. What is the cause of coldness in clay soils?

Radiation.

A. Clay soils holding water have much of it to evaporate, and radiation always produces cold.

117. Q. Does drainage warm the soil?

A. Yes; as it reduces the amount of water to be evaporated and radia. tion always produces cold.

118. Q. What is meant by firming the soil ?

Firming the

A. It is a newly coined expression to indicate a process as old as the Soil.

agriculture of Virgil. It means pressing down the soil with the feet or a roller, so that the soil and seed or transplanted seedling and soil are brought into intimate contact so that germination or vegetation may be hastened and promoted.

119. Q. What is sap? 
A. Sap is water circulating in plants, and containing gaseous matter and certain eartls and salts in solution or suspension.

Frost.

120. Q. Why do young vegetables and the tender leaves of all plants suffer more from frost than older growth?

A. Because supercharged with sap they evaporate rapidly and become cold and freeze sooner than parts more mature.

Mold. 121 Q. What is vegetable mold ?

A. It is a dark-colored soil best known as the upper strata found in woodlands. It consists of decayed weeds, twigs, branches of trees, decayed grass and other vegetable matter mixed with surface soil.

Gypsum. 122. Q. What is gypsum?

A. It is known sometimes as plaster of Paris, sometimes as sulphate of lime. It is the least valuable of the mineral manures, pound for pound, but is highly thought of as a top dressing for grass lands, clover thriving especially after its application.

Insecticides. 123. Q. How can I kill garden ants?

A. By using molasses mixed with paris green.

Insecticide. 124. Q. What is the best insecticide ?

A. The discovery of an article which, while not injuring the cucumber plant, will destroy the bug which infests it from the time of its germination until it has attained a growth of three or four rough leaves, is a subject of the greatest interest to all cultivators of this fruit. So much has been written of a contradictory nature upon this subject that it is next to impossible to determine what remedies to adopt. We would suggest that each cultivator experiment for himself with several cômpounds: for instance, one part of hellebore mixed with four parts of ground land plaster; oue purt of slug shot mixed with six parts of land plaster; one part Paris green mixed with twelve parts of land plaster; and one pint of kerosene oil mixed with three quarts of sawdust.

Good results in the destruction of squash bugs have been obtained by the application, under ground about the roots of the plants, of the liquid carbon bisulphicle, the fumes of which are quickly deadly to insect life. Eight ounces of Paris green to 100 gallons of water is Professor Cook's wash for the cucumber beetle. Oil of Lavender is very efficient.

Paris Green. 125. Q. In the use of Paris green, what quantity should be applied ?

$\Lambda$. On an average one pound to twenty-five or thirty of plaster or lime, or one tablespoonful to four gallons of water.

Paris Green. 126 Q. Name the six or seven insecticides in most general use, attaching suggestive prices for same?

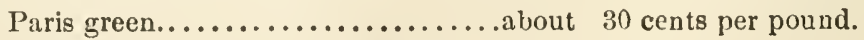

Slug shot ................. "

Hellebore................. " " 25 " " "

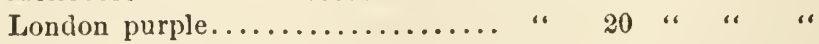

Persian insect powder ......... " 75 " “ “ “

Hammond thrip juice. 
127. Q Do you recommend applying insectitcides in powder or solu- Water. tion?

1. Try both ways, water on small areas, powder on large tracts.

128. Q. Does water act as a fertilizer? Water.

A. Impure water does because it contains fertilizing matter absorbed from decaying material. Pure water acts in a fertilizing way only by the gases which it contains.

129. Q. Is rain water of a fertilizing character?

Rain Water.

A. Yes; as it contains ammonia, which it absorbs during its passage through the air.

130. Q. Is there any foundation for the proverb that snow is the poor snow. min's manure?

A. There is, as snow in falling absorbs more fertilizing elements than the same amount of rain, and when resting on the earth acts as a blanket to stop the ammoniacal emanation from the soil.

131. Q. Does a large crop of cedar-tree berries and other wild bird fruit Severe indicate the approach of a severe Winter?

Winter.

A. No, not necessarily ; it simply is the resultant effect of a previously mild Winter. After a cold Winter there often follows a mild one, and the berries then afford a good supply of food for birds.

132. Q. What is dew?

Dew.

A. It is water condensed from the atmosphere and deposited upon bodies cooler than the atmosphere.

133. Q. Why are cloudy nights less dewy than clear nights?

Radiation.

A. Because clouds reducing radiation prevent objects parting with as much heat as they would if radiation was uninterrupted.

134. Q. Why is it that gravel walks are in the morning found dry, Radiation. while the grass on both sides is wet with dew ?

A. Because gravel does not radiate as rapidly as grass, therefore does not become a depository of dew.

135. Q. Why is the subject of dew one of much importance to the gar. Dew. dener?

A. Because the study of the subject impresses upon the gardener the fact that the atmosphere contains a quantity of moisture, and that by keeping his garden soil loose that air may enter it he may in dry seasons profit by the natural moisture of the atmosphere.

136. Q. What is white frost?

Frost.

A. It is frozen dew.

137. Q. Why is moonlight said to be cold?

Cold Night.

A. Because on moonlight nights the radiation is rapid, there are no clouds to stop it.

139. Q. Which is the leading fruit-growing section of the country? Fruits.

A. Astonishing as has been the increase in fruit growing in the old States, it cannot be compared to the astonishing developments in California, one day's shipment in 1892 from Los Angeles, California, being two 
hundred and ten cars of green and canned fruit, at an a rerage valuation of $\$ 6000$, or one and one-quarter millions of dollars.

A single California grower of. Bartlette pears shipped in 1892 seventyfive cars from the trees of one ranch.

Lime.

139. Q. Why is it that lime can be advantageously applied to many soils?

A. Because by its chemical action it sets free ammonia from deptlis below the reach of the plow.

\section{Lime. 140. Q. How should oröinary lime be applied?}

A. It should be first reduced to a powder by a slacking process, and, when perfectly dry, spread evenly upon the surface, care being taken to break any lumps.

Ashes. 141. Q. Of what value are unleached wood ashes as a fertilizer?

$\Lambda$. Valuing potash at 5 cents per pound, and insoluble phosphoric acid at 5 cents per pound, hardwood ashes, as produced in ordinary stoves, is worth about $\$ 12$ per ton.

Stable

Manure.

Soils.

Soil

Substances

Subsoil.

Peat.

Peat.

Alluvium.

Rotation.

Chemical

Action.
142. Q. Is it proper to apply stable manure simultaneously with lime?

A. No; no manure of any kind should be applied with lime, as its ralue would be reduced. It would be best not to apply such manure for two or three months after an application of lime.

143. Q. What constitutes a loamy soil ?

A. Loam is a mixed material of earth formed of disintegrated rocks and generally found removed from the locality of its origin. It is more fertile than clay, containing more vegetable matter.

144. Q. What are the two principal substances in soil?

A. The organic, as oxygen, hydrogen, carbon and nitrogen, products of substances once endowed with life. The inorganic, wholly mineral, as oxygen, sulphur, phosphorus, carbon, silica, potash, lime, soda, and iron. 145. Q. Is a good subsoil important to a garden?

A. Very important, as a clay, near the surface, keeps the surface satu. rated with water after a rain, causing it to be cold, or if the subsoil be of gravel and near the surface it passes off surface moisture too rapidly.

146. Q. How may peaty soils be improved?

A. By draining and by burning the surface.

147. Q. How are peaty soils formed?

A. They are composed of mosses and water plants mixed with sand and clay deposited by water, the whole amalgamated into a spongy mass. 148. Q. How are alluvial soils formed?

A. By a deposit of sand and earth by water. These soils are generally remarkably fertile.

149. Q. Why is rotation of crops practiced?

A. Various plants require different foods ; without rotation a soil would be exhausted of those elements mostly used by the plant cultirated.

150. Q. Why do different results follow the application of the same manure upon soils apparently similar?

$\Lambda$. Because of distinct chemical action in the soil of different localities, 
and even of different fields, and because of a difference in the degree and character of fertilizing elements remaining in the soil from previous manur. ings.

151. Q. What are the inorganic constituents?

A. They are the mineral portions of plants taken into their circulation, Constituents. as potash or lime.

152. Q. How is potash extracted from plants?

l'otash.

A. It is procured from wood ashes. It is clear, therefore, that wood ashes is a valuable fertilizer.

153. Q. How is soda obtained from plants?

Soda.

A. It is found most largely in the ashes of sea weeds, but is present in small quantity in the ashes of all plants.

154. Q. How is lime obtained from plants.

Lime.

A. From the ashes, same as potash and soda, as it forms a part of all vegetable growth.

155. Q. What is phosphate of lime?

Phosphate of

A. It is a combination of phosphoric acid with lime. It is the princi-Lime. pal portion of bones, the other portions being gelatine and fat.

156. Q. From whence do plants obtain their phosphate of lime?

Phosphate.

A. It is found in a limited extent in nearly all soils, but it is artificially applied in the form of bone dust, Charleston and Florida rock.

157. Q. How do plants obtain bydrogen?

Hydrogen.

A. From water, by the agency of their leaves, tissues and roots.

158. Q. From whence do plants obtain nitrogen?

Nitrogen.

A. Principally through their roots, taken up in a form of ammonia. It is found in the form of vegetable albumen and gluten and in the seeds of plants. Plants also respire nitrogen by their leaves.

159. Q. How is it that there is such a variety of vegetable products? Combina-

A. Because of combinations in varying proportions between simple tions. elements.

160. Q. That are the organic constituents of plants?

A. They are the products of vegetable life, examples being starch, Constituents. sugar, and gum.

161. Q. What is hydrogen?

Hydrogen.

A. Hydrogen, like oxygen, is known in a state of gas, and is found in water and all combinations of animal and vegetable substances.

162. Q. What is nitrogen?

Nitrogen.

A. Nitrogen is also a gas, without smell, taste or color, and is found in the atmosphere and in all animal and some vegetable substances.

163. Q. How do plants get their carbon?

Carbon.

A. Carbon in the form of carbonic acid gas is absorbed from the air by plants, and to a small extent is taken by the roots from decaying vegetable matter.

164. Q. How do plants get their oxygen?

Oxygen.

A. From water, which they imbibe through their roots and by their process of leaf inspiration. They also give out oxygen when it is in excess. 
Plant

Element.

Carbon.

Oxygen.
Growth.

165. Q. What are the principal chemicals influencing plant growth ?

A. Carbon, oxygen, nitrogen, and hydrogen.

166. Q. What is an element?

A. An element is a body composed of one kind of matter. Carbon, oxygen, hydrogen and nitrogen are elements, but when combined with other substances the new formations are called compounds.

167. Q. What is carbon?

A. It is an element forming a large proportion of vegetable substance. $A$ familiar form of carbon is charcoal.

168. Q. What is oxygen?

A. An element known only in a state of gas. It is without taste, smell or color ; it is found in water, air, and in minerals, and is necessary to the continuance both of plant and animal life.

Treatment of 169. Q. Should manure be kept in piles or heaps?

Manure. A. Yes, and covered up with soil, as by putrefaction in the open air, five per cent. of the nutritive matter will be lost in a month, whereas, if piled and covered, the gases are cooled and absorbed by the external covering.

Manure

odor.

170. Q. Why do manure heaps emit a pungent odor?

A. Because of the gases generated in fermentation, principally sulphuretted and phosphuretted hydrogen.

Horse Dung. 171. Q. Why is horse dung hotter than the excrement from cows?

A. The excrement of horses fed on grain contains a greater amount of nitrogen and less water than that from other farm animals, consequently it ferments more rapidly

Nitrogen. 172. Q. What effect has nitrogen on plants?

A. It increases the foliage, lengthens the stems of the plants, and prolongs their growth.

Sulpliuric

Acid.

173. Q. Why is sulphuric acid applied to bones intended for fertilizing?

A. Because the phosphate of lime in the bone is the chief manurial substance and a larger portion of it is made quickly active as plant food by the application of the sulphuric acid. The resultant of the bones thus treated is afterwards known as superphosphate of lime.

Pliosphate of 174. Q. Is phosphate of lime soluble?

Line.

A. It is very slowly soluble, especially in dry seasons. Superphosphate of lime is extremely soluble. Phospluate of lime continues to exercise a slow but beneficial effect upon fertility, while superphosphate of lime, expending itself in half the period, is a more profitable application.

Guano.

Tha rnyard Manure.
175. Q. What is Peruvian guano?

A. It is the excrement from sea birds, and when good contains lime, potash, soda, sulphuric acid, phosphoric acid, and nitrogen, the two last named being the most valuable.

176. Q. Is it true that land never tires of barnyard manure?

A. Yes, it is ; because stable dung contains all the ingredients and is in a state ready almost for immediate use by growing plants. Sometimes, however, it is advantageous to cease the use of farmyard manure and 
apply manufactured fertilizers to reduce the number of insects and to afford an opportunity to cleanse the soil of weeds.

177. Q. Do the qualities of animal excrement differ?

Excrement.

A. Very widely; depending not only on the food supplied, but on the race ; as cows, horses, pigs and sheep require and assimilate or reject different chemical constituents.

178. Q. What effect has lime on plants?

A. It generally shortens the period of growth and hastens the time of Lime. ripening.

179. Q. Is there a varying influence depending upon the moon's phases The Moon. exercised on vegetation?

A. No; not to the slightest degree. The peasantry of all nations, from days of earliest record to the present day, have such a belief, and regulate seed sowing, fence making, roofing, killing of meat, and other farm and domestic duties by the moon's phases; but there is not, to any degree, any foundation for the practice.

Analogous to this there is the belief that it is dangerous to sleep under the moon's rays, and that insane persons are more visibly affected during certain conditions of the moon ; but this is an exploded idea.

180. Q. What are the properties of light on vegetation?

A. Light has three properties :

Light.

(1). Luminosity.

(2). Heat.

(3.) A chemical property termed actinism.

181. Q. What effect have the rays of the sun upon vegetation?

Sun Effect.

A. The luminous rays excite and quicken the vital action of growing plants by which they decompose carbonic acid gas.

182. Q. What are the effects of solar heat?

Solar Heat.

A. It influences vegetation from the shooting of the germ to the perfection of the fruit or seed; under solar heat the flowers of plants consume oxygen while at the same time the leaves are emitting it.

183. Q. What is the effect of actinism?

Actinism.

A. It quickens vegetation. Seeds will germinate in darkness, but to vegetate freely they must have light.

184. Q. What is the distinction between germination and vegetation? Germination

A. Germination is the putting forth of a bud or germ. Vegetation is or the condition of subsequent growth.

Vegetation.

185. Q. Is it economical to make liquid manure by soaking stable ma- Liquid nure in vats of water.

Manure.

A. Yes, because the valuable portions of the manure become thoroughly amalgamated by fermentation, and the process of decomposition is completed before the manure is applied to the crop. Manure, in liquid form, is very thoroughly and efficiently applied to the soil.

186. Q. Why does decaying cabbage smell so badly?

A. Because of the escape of sulphuretted hydrogen gas. 
Autumn

Coloring of

Leaves.

Glucose.

Paris Green.

Fertility of

Land.

Condition of Farmers.

Agricultural Depression.

Farm

Jislike.

Agricultural Machinery.

Railroads.
187. Q. Is frost the cause of the brilliant coloring of Autumn leaves?

A. No; generally a physico-chemical phenomenon allied to the ripening of fruit, a decrease of vital power, resulting often from injury, inflicted in early growth, as from lightning stroke, barking by eattle, from soil stamping by cattle, or occasionally it is the result of a want of nutrition consequent on a hot dry Summer and Autumn. At other times, consequent upon the swelling of the next year's buds at the base of the leaf stems, cutting off the circulation. These and other physical causes render the plant juices susceptible to chemical changes, producing eolors of varying degree.

188. Q. What is glucose?

A. A form of sugar generally made from Indian corn. It naturally occurs in varying degrees in the juice of plants and is produced in large quantities from Indian corn and used in various commercial ways. For table purposes it is not used, being inferior to cane sugar.

189. Q. Is Paris green, being a form of arsenic, dangerous to use upon potatoes, tomatoes and egg plants?

A. Never dangerous on potatoes, only dangerous on tomatoes and egg plants after they have developed half-sized fruit, as it might be carried to the table.

190. Q. Is the fertility of the land in the old States maintained ?

A. No; it has decreased.

First, there being too much dependence placed upon commercial fertilizers, and second, through a want of knowledge of the good old agriculture practices of rotation of crops and green manuring.

191. Q. Do farmers in the old States live better than formerly?

A. They did much better for fifteen or sixteen years after the war of 1861-1865, but are now, by reason of the agricultural depression, returning to antebellum conditions of domestic affairs.

192. Q. What are the general causes of the agricultural depression?

A. It is a condition of things which extends over the entire agricultural world. The cause is overproduction, brought about by the introduction of labor-saving machines and railroad extension, leading to overcropping. The labor of supplying the world with food has been diminished. One man now does the work of fifty.

193. Q. Why do the young people quit the farm?

A. Young Americans as a rule are not disposed to engage in the laborious work of a farm; they prefer to embark in commerce or manufactures.

194. Q. Has there been a profit to farmers by the development of laborsaving machines?

A. No ; not a profit, only a convenience. The cheapening of farm products by the use of machines has been one of the causes of overproduction, and the prevalent agricultural depression.

195. Q. Does the building of railroads increase the value of lands?

A. Yes; they increase the value of farms within a mile or so of stations ; but railroads often decrease lands laying further off, as by the prolongation of the tracks new competing territory is developed. 
196. Q. Does the development of manufacturing villages increase the p'roduction. value of the production of the adjacent farms?

A. Not to any great extent; not beyond the saving of freight from other points, as prices are generally regulated by the rates prevalent at the large centres of commercial trade.

197. Q. Do the people living in the cities generally profit by the low Low Prices. prices brought about by the agricultural depression?

A. No; for while the raising of Western beef is almost unprofitable to the herdsmen, the people of the cities pay almost as much as formerly, the profits going to the middle men, who by the use of immense capital drive out all competitors and keep the retail prices up.

198. Q. Is the tendency in the old sections of the country to divide Division of farms or to unite them?

farms.

A. In the old States to divide, farms going into the hands of smaller operators.

199. Q. How much labor on the large farms of Dakota does it take Farm Labor, to provide bread for 1000 persons?

A. The labor of each man employed, estimating his employment as continuous for twelve months, is $\mathbf{5 5 0 0}$ bushels. Another man's labor for a year converts this wheat into flour ; five men's labor for a year transfers it to Philadelphia ; three more convert it into bread and sell it, thus ten men working one year produce bread for 1000 mouths.

Continuing in this line of calculation based upon the use of labor-saving machinery, if twenty men make the clothing, twenty more build the houses, twenty more provide the literature and amusements, twenty more manage the public offices and ten more provide miscellancous necessities, we thus have 100 adults providing all the necessities for 1000 mouths. If 1000 mouths represent 200 men, we perceive that while 100 of these men have employment all the year round the other 100 are idle, consequent upon the development of machine processes and the expansion of railroads and opening of new lands.

200. Q. Are the agricultural lands in any of the States worked to their Agrieultural full capacity?

A. They are not; American farmers have no conception what it is to work land to its full capacity of production. The most intensely cultivated gardens in the United States do not yield more than the average production of whole districts at France, Belgium and Holland, and yet the quantity of grain harvested of crop 1891 was $3,538,000,000$ bushels.

201. Q. Does subsoiling pay?

A. Yes; on all lands having a retentive subsoil, as such holds so much moisture as to retard healthy plant development, as such soils also do the unrestricted development of tap root and deep running fibres.

Such soils should be broken up by a snbsoil plow or coulter affixed to a plow beam and run in the bottom of every open furrow, after a common 
plow. Another system of breaking subsoil on fields where a root crop is contemplated is, after the field has been plowed and harrowed, to trench out at three feet, and in every open trench to run a subsoil plow or coulter breaking the hard part, apply the fertilizer, ridge over by splitting the standing ridges, draw down to a flat surface, and drill the seed directly over the fertilizer, and over the deeply broken bed through which will freely drain all superfluous moisture and into which the roots can deeply delve.

Sandy soils, which do not retain moisture, nor offer impediments to the downward development of roots as carrots, parsnips or mangolds, do not require subsoiling.

Steam

Plowing.

202. Q. Why has not steam plowing been popular in the United States?

A. For two reasons :

First. In the old States the farms are not large enough to warrant the purchase of such expensive apparatus, the cost being $\$ 10,000$ to $\$ 20,000$, according to style and size.

Second. On the large farms of the West; far removed from well-appointed machine shops, the difficulty in making repairs and the difficulty in holding expert machinists, are all serious.

The writer has known of the importation of two complete sets of plowing engines and tackle of Fowler's make, each costing about $\$ 18,000$, neither of which ever paid the freight.

The writer worked on Bloomsdale farm during the Summers of ' 71 and '72, endeavoring to perform plowing by direct traction by the use of a three-wheel rubber-tired Scotch engine, but gave up the scheme as impracticable.

203. Q. Describe briefly the methods of plowing by steam?

A. In Europe there are three distinct systems of drawing the plows, harrows, etc., etc.

First: The direct system, by which self-propelling steam engines pass over the land and drag the implements. This is very wasteful of power and impracticable on soft or slippery soil.

Second. The rope and windlass system, under which the locomotive remains on the headland, and pulls the implements back and forth, by means of a wire rope winding on a drum beneath the engine and across the field to the opposite headland, where it winds around a similar drum on a second engine, or around a drum on an anchored windlass. The implements being in gangs of plows, cultivators or harrows.

In New Jersey there has been built a completely designed farm traction engine for chopping the earth instead of plowing it. This new system, one of many knives revolving rapidly, was conceived at and first tested on Bloomsdale Farm, August, 1886, the chopping attachment being applied to a steam farm spader, then belng tried. The cutting arrangements are of many independent, rapidly revolving knives, chopping out slivers of earth something similar to the chips of wood cut by a steam planer. Such a system of choppers does not take so much power as required to 
draw plows and it bids fair to be practicable, particularly as after the passage of the engine the earth is left in the condition of an absolutely perfect seed bed six to eight inches deep.

204. Q. In draining land where there is very slight declivity state the Draining. least fall from which a good result can be expected?

A. Half an inch to every sixteen feet, though one-quarter of an inch in sixteen feet has been known to work well on a line of open drain of 1000 feet.

205. Q. How shall I make the cheapest and simplest level for use by Draining ordinary farm laborers in ditch digging?

Level.

A. Decide first on the pitch or declivity of the ditch or drain.

If, for example, one inch in sixteen feet is desired, then take a sixteen. foot board and plane off both edges perfectly straight, and of equal width from end to end, then with a chalk line mark off on one side an oblique line from one inch to nothing and rip out. Next procure a carpenter's spirit level.

When digging the ditch, shovel the earth out so that when the leveling board is placed with the wide end down the ditch, it will rest all of its length on the lower edge on the earth and place the carpenter's spirit level upon the top smooth edge, thus indicatiug the true level, when the pitch will be one inch every sixteen feet or five feet in a 1000.

206. Q. Is there any foundation in fact for the popular belief among Superstition. horsemen that a horse with white hoofs must necessarily have soft feet ?

A. Veterinary surgeons say, if there is any appreciable difference in density of pigmented or non-pigmented hoofs it is so slight as to make no practical difference as to soundness or usefulness.

207. Q. How many acres does the United States Land Office sell an-Land Sales. nually ?

A. In the year 1889 , the sales amounted to $19,000,000$ acres.

208. Q. What proportion of our agricultural productions are sent to Exports. foreign countries?

A. About one-tenth-a small proportion after all-and yet it is a greater percentage than the agricultural exports of any other country. This export is not likely to reach a greater proportion, as the nine-tenths will always be needed at home, and as many other nations are sending to the purchasing countries their surplusses of the same kind of productions. Our export trade if increased must be in the line of concentrated articles as cheese, butter, canned fruit and vegetables. The annual value of our farm productions exported amounts to about $\$ 400,000,000$, with the agricultural imports just about equal to the exports.

209. Q. Among the importations, what agricultural products are they American which American farms should produce?

A. First. Sugar, the amount imported being equal in value to our wheat and filour exported.

Second. Flax, hemp and other fibre imports, which amount in value to nearly the total value of our boasted cotton crops.

Third. Fruit, of which $\$ 20,000,000$ worth are annually imported. 
Corn and Grains.

Coru.

Exports.

Wheat.

Exports.

Wheat

Export.

Yield.

Wheat to Population.

oats.

oats.

Buckwheat.

ibarley.

Itye.

Cereals.

Eotatoes.

Hay.
210. Q. What is the proportion to each inhabitant of corn consumed domestically and in the arts, in the United States?

A. About thirty-five bushels, an amount greater than the per capita consumption of any cereal in the world.

211. Q. What is the average yield per acre of corn in the United States?

A. Twenty-four bushels or about one and one-sixth acres grown to each one of the population of sixty-tive million, the product valued at $\$ 675,000,000$.

212. Q. What proportion of corn and cornmeal is exported?

A. Not over four per cent.

213. Q. How much wheat is annually grown in the United States?

A. $460,000,000$ bushels, grown on $35,000,000$ acres.

214. Q. How much is annually exporteci?

A. $\Lambda$ bout $125,000,000$ bushels.

215. Q. Is the exportation of wheat likely to increase?

A. No; the western nations of Europe are our only customers, and they draw from every quarter of the globe. The 150,000,000 bushels required in excess of their production they buy where they can get it the cheapest, and probably in the future will purchase less from us.

216. Q. What is the average yield per acre in the United States?

A. Twelve bushels.

217. Q. What is the proportion between the average acreage of wheat and the population?

A. Something over one-half acre of wheat to each inhabitantor 7 bushels to cach inhabitant.

218. Q. How many acres are annually cultivated in oats?

A. About $21,000,000$.

219. Q. What is the average production per acre of oats?

A. Twenty-seven bushels.

220. Q. Of buckwheat, how much is grown annually?

A. About 1,000,000 acres, average twelve bushels to the acre.

221. Q. What quantity of barley is grown in the United States ?

A. $3,000,000$ acres, producing $t$ twenty-one bushels to the acre.

222. Q. What is the annual area of rye in this country?

A. Slightly less than $3,000,000$, producing an average of twelve bushels to the acre.

223. Q. What is the average production of all the cereals per head of our population of $65,000,000$ ?

A. About fifty-two bushels per head, immensely greater than that of any other country in the world.

224. Q. What is the annual production of potatoes in this country?

A. About $200,000,000$ bushels, produced on 2,750,000 acres, an average of nearly 3 bushels to each inhabitant. 'Total crop valued at $\$ 91,000,000$.

225. Q. How much hay is produced in the United States?

A. Nearly 50,000,000 tons from about 40,000,000 acres, the estimated value of the product being $\$ 100,000,000$. 
226. Q. What are the agriciltural statistics of tobacco ?

A. Nearly $600,000,000$ pounds grown on about 750,000 acres, valued at $\$ 50,000,000$.

227. Q. What are the statistics as to farm live stock in the United Live stock. States?

A. The number of animals taken from the last report of the Department of Agriculture placed horses at 14,000,000, mules 2,300,000, milch cows at $16,000,000$, oxen and beeves at $37,000,000$, sheep $45,000,000$, and logs $52,000,000$, valued at $\$ 2,420,000,000$.

228. Q. What is the principal cause of fluctuations in prices of agricul-Fluctuationse tural productions?

A. The varying meteorological conditions of the season of growth in each of the 3000 counties of the Union. No legitimate pursuit of man is so great a lottery as agriculture.

229. Q. What plants are used as salads? Salads.

A. Very little beyond lettuce, endive, corn salad, cress and mustard, is known by American gardeners of the wide variety of foliage-bearing plants used in Europe as salads, served uncooked and boiled. Beet tops, succeeding spinach, are a favorite dish in England.

Radish seed pods, succeeding the pithy roots, are, when small, very delicate, and used to a large extent in France.

Cardoon, chicory, dandelion, nasturtium, scurvy grass, sorrel, seakale, swiss chard, turnip tops, are all favorites, and their extended use, adds much to the profit of a garden and the enjoyment of a family in the country.

230. Q. How is cauliflower cultivated?

A. This delicious plant, like broccoli and French artichoke, is distinguished from other table vegetables by producing edible flower heads. By long years of selection and culture of some accidental natural variation of this plant of the cabbage family discovered in the Middle Ages, the flowers of the cauliflower have been, to a large extent, rendered abortive, and the flower stems multiplied, shortened and thickened till they have been bred to form a half-globular compact crown or head which, when cooked, is tender as marrow, and the choicest of all esculent vege. tables. Varying with climatic and soil conditions, the seed is sown at all seasons. In hotbeds at close of Winter, out of doors when the apple is in bloom, again when the oak is in full leaf, again at Midsummer, and again during Winter under glass. The young plants are treated the same as cabbage, and the larger plants require the same rich fertilization and culture-indeed more intense culture, as only those cauliflowers are good which are grown quickly. We offer only seed of the highest quality. The early varieties are most likely to succeed in the hands of inexperienced growers. Sow the early sorts in seed-beds beginning of Autumn, keep them in a "cold frame," protected by sash from severe frost during the Winter, and transplant into deep and very rich ground as soon as frost ceases. Handglasses or boxes placed over 
them at night, when they are put out, are useful. It should be observed, however, that success is very uncertain in dry localities. In Pennsylvania the cauliflower seldom heads well unless under glass, or in cold frames. But there is little difficulty in having fine cauliflowers when planted in frames under glass, at close of Winter, so as to advance them ahead of the early Summer heat. The late varieties mature in Autumn, and are sown at the same time, and managed similarly to cabbage. They do best in localities where the atmosphere is damp and saline, as on the coast. We may add that cauliflower can only be grown on rich, well-tilled, well-watered soil, and that it can hardly be overfed.

Kohl-Rabi.

231. Q. That is kohl-rabi?

A. This plant, used both for table and for cattle feeding, is a cabbage in which the cultural development has been directed to the stalk, not to the leaf. The enlarged stalks, taking the globular form of turnips, are more hardy and nutritious than turnips.

Any good soil will produce a crop, the plants for which may be grown like cabbage in seed-beds for transplanting, or sown in permanent position in three-feet rows.

Sow the seed for table use at any period when cabbage may be sown. Drill in rows at two feet and thin to six inches.

For cattle feeding drill the seed in Midsummer for Autumn develop. ment. Yield 300 to 400 bushels to the acre.

Egg Plant. 232. Q. Give cultural directions for egg plant.

This seed is generally sown under glass and transplanted to the field two or three weeks after corn-planting season. The plants are set in rows of five feet and at three feet in the row. The land cannot be too highly fertilized for this crop-very short, thoroughly rotted stable manure or similar preparation is best; strong manure, or hot. rank manure, is unsuitable. Sow in hotbeds or other protected place early in the Spring; when up two or three inches transplant into small pots (which plunge in earth), so as to get stocky, well-rooted plants, and late in the Spring, or not till the commencement of Summer, unless the weather be warm, transplant into thoroughly worked, rich and recently well-manured ground. A good plan is to open a deep, wide trench, filling it nearly with manure ; restore the earth and plant therein, placing the plants three feet apart each way. The seed does not vegetate freely ; repeated sowings are sometimes necessary. It is almost useless to attempt the culture of egg plant unless the proper attention be given. In growing the egg plant in the Summer and Autumn months in Florida, great trouble is sometimes experienced in getting a stand of plants owing to the excessive leat and beating rains. This difficulty can be largely overcome by slialing the ground where the seed is sown. If sown in beds, the shacling may be accomplished by means of frames covered with seed-bed cloth, or by blinds of slats or common boards properly supported over the beds to cut off the direct rays of the sun. If the seed is sown where the plants are to remain ( $\mathrm{a}$ bad practice) the shading may be done by using palmetto fans or leaves, plac- 
ing them one each on the north and south side of the hill, the tops meeting over the seed. This plan is used by some of the most successful growers in the Gulf States.

About 3000 plants are required to plant an acre. These plants should produce an average of three to four fruits, weighing two to three pounds each. Our selected seeds are always taken from fruit weighing eight to tell pounds each; we have had them of thirteen pounds in weight. Com. mission merchants in Philadelphia pay the market gardener about, on an a.verage, one-and-a-half cents per fruit. The highest prices are eight and ten cents per fruit.

Florida fruit arrives in Philadelphia the latter part of November, and commands $\$ 6$ to $\$ 8$ per barrel crate. Earlier in the Autumn the market is supplied by fruit from Jersey. Towards Christmas the price of Florida egg plant rises to $\$ 10$ per barrel crate and then declines by April to $\$ 6$ to $\$ 8$, and by May to $\$ 5$, after which they are likely to arrive in a damaged condition and be worthless. Egg plant fruit can be grated and canned for Winter use.

233. Q. Why don't I succeed with lettuce?

A. To have fine lettuce in early Spring, sow in seed-bed from commencement to middle of Autumn. During Winter protect the plants by a box covered with window or other sash, or with litter, as they stand on the ground. Early in the Spring transplant some into rich ground. The others force under the sash. Or in early Spring sow in a hotbed and transplant, but Autumn-sown plants are best. For a later supply, sow in drills when the cherry is in bloom ; when up a few inches thin out, leaving plants at proper distances; this is a better plan than transplanting late in the season. For this purpose use Bloomsdale Reliable, Landreths' Forcing, Virginia Solid Header and Heat-resisting varieties, which we have selected as standard sorts by reason of their ability to resist heat and the longer time they are in condition for the table than some other kinds which shoot to seed as soon as the head is formed.

234. Q. How should asparagus be planted?

A. This plant succeeds best on sandy soil, though reclaimed marsh land, when freed from water, is admirably adapted to its culture; the lighter the soil the earlier the plants shoot in the Spring. Of whatever character the ground may be, it should be well cleared of trash or other incumbrances, and in a good state of cultivation. The land is prepared by opening deep trenches six or eight feet apart, by passing a two-horse plow twice to each furrow, throwing a furrow slice to the right and left, and fnally cleaning and deepening the furrow by a third passage of the plow. The roots are planted in the bottom of the furrow, at eighteen inches apart, and covered by an inch of soil.

Stable manure may be applied in the furrow before the roots are placed, or on top of the roots after they are covered.

North of the latitude of Washington, Spring planting, when the apple is in bloom, is considered to give the best results, but soutb of Washing- 
ton Fall planting has proven the best. We can ship asparagus roots, from October to March, to any point within 1000 miles, but they must be planted as soon as received, as if exposed to the air are soon injured in vigor.

If the rows be six feet apart, about 6000 plants are required to plant an acre; if at eight feet apart, 4000 plants are required to the acre.

One-year-old well-developed roots are better than older ones. When well planted and fertilized a cutting of stalks can be made about three times the second year after planting. Cutting should not be continued too late in the Spring or the roots will become exhausted if the shoots are not allowed to develop fully, for of course it must be understood the leaves are the lungs of the plants. After cutting has ceased the ground should be worked by plowing away from the rows and manuring alongside, after which the earth should be thrown back. Twenty bushels of salt to the acre, sown broadcast, may be used to advantage annually. The roots of asparagus (though some penetrate six and eight feet in depth) are, many of them, inclined to run near the surface; the cultivator should accordingly, as far as possible, aim at flat culture. Early crops, like peas, may be profitably grown between the rows of asparagus for the first two or three years. Asparagus can be bleached and made especially tender by mulching or covering with six inches of fine cut hay, straw or leaves.

A season's culting covers eight to ten weeks, and profitable cutting continues up to ten years from planting, after which time the beds are considered unprofitable by market gardeners.

From 800 to 1500 two pound bunches of asparagus can be cut to the acre, and a good field-hand can cut 150 bunches in a day. In the Philadelphia market asparagus bunches are always made to weigh two pounds, and vary from ten to fifty stalks to the bunch, according to condition of culture. A skillful workman can trim, wash, pack and tie about 300 bunches in a day. At the New York market green-pointed "grass" is demanded, the Philadelphia market calls for white-pointed. Both colors are found in the same field. The price obtained in the Philadelphia market by truckers from ${ }_{n}$ commission men is on an average ten cents per bunch, never lower than eight cents, though sometimes the price paid by commission men is forty to fifty cents.

Asparagus is always in demand, such a thing as the market being seriously glutted with it never occurs. The variety known as the Colossal is the best, producing shoots often one inch in diameter, and sometimes as many as fifty to the plant.

One pound of asparagus seed will produce 2500 plants. The seed may be sown when the cherry is in bloom or among the earliest operations in the Spring, and is usually drilled in rows of ten inches. If the land be friable, fertile and well eultivated, these seedlings can be set out the next Spring. 
bloom or from suckers taken from established plants. If the sced be sown the plants may be raised in beds and transplanted. The seedlings or sets should be planted out in rows at four feet apart, at eighteen inches to the row. Artichoke in a congenial climate will stand for several years, but success with it in the United States cannot be expected north of the cotton belt. It is a French vegetable, the flower buds of which are eaten.

236. Q. How are mushrooms grown?

Muslirooms.

A. The culture of mushrooms to the initiated is very easy, but it is a subject of much difficulty to the novice. We cannot attempt here to give at length the necessary directions, but refer the inquirer to some of the various publications upon the subject.

Plant one pound of spawn to the square foot. Kept on sale in the form of bricks. The spawn is planted in dark pits, caves, in outdoor hotbeds, or on banks of compost. Per brick of about $1 \frac{1}{\frac{1}{2}}$ pounds, 15 cents.

Any mushroom, or toad stool, the stem of which underground springs from a cup or socket, or which has any suggestion of such a socket, should be set down as poisonous. The most intensely poisonous of mushrooms-the Amariata bulbosa and the Amariata vernus-are generally found in the woods, though sometimes in the open field. They are positively deadly, taking effect in about ten hours after eating.

237. Q. How are onion sets grown?

Onion Sets.

A. Drill, when the apple is in bloom, sixty to seventy-five pounds of seed to the acre. At Midsummer, or whenever the tops die, remove the small bulbs, buttons or sets, as they are indifferently called, produced by this process, to a dry place. In the Autumn, or early in the following Spring, replant them in rows, the sets two inches apart, the rows wide enough to hoe between them. Observe: If not sown quite thickly in the first instance, they attain too large a size, and when replanted sloot to seed.

In growing onions for the market, either from seed or sets, an unusually large size is not to be desired, two to three inches in diameter being about the most desirable size for shipping. A vigorously growing onion crop frequently can be hastened to early ripening at near the desired size by simply stopping the vigor of growth by running a scuffie hoe under the bulbs on one side so as to cut off one-half the roots. Such a course of treatment will reduce the excess of vigor and forward maturity. If the grower awaits the development of mammoth onions, or even large ones, he frequently lets pass opportunities for paying sales, far more profitable than afterwards realized.

238. Q. What are Bermuda onions?

Bermuda

A. An early sort originally grown in Bermuda-now largely grown in Onions. Florida, Louisiana and Texas and some little in Georgia and Carolina.

Down the Mississippi, below New Orleans, 100,000 barrels of marketable onions are grown annually. All the early ones formerly grown were known as Creole onions, half round and light red, but they are fast being supplanted by the Bermudas. 
The following table, extracted from Bulletin No. 27, of the Louisiana State Experimental Station, clearly shows the relative development of size and relative period of maturity to that size. It will be perceived at a glance that the Bermudas were nearly twice as large and fifteen to twentyfive days earlier than the Creole.

Transplanting Onions at Baton Rouge.-Sown in Augugt, 1893.

\begin{tabular}{|c|c|c|}
\hline VARIETY. & Average Wt. & Earliness. \\
\hline $\begin{array}{l}\text { *Red Bermuda, transplanted } \ldots \ldots \ldots \ldots \ldots \ldots \\
\text { Red Bermuda, not transplanted } \ldots \ldots \ldots \ldots \ldots\end{array}$ & $\begin{array}{l}4.5 \text { ounces. } \\
4.5 \text { " }\end{array}$ & $\begin{array}{l}\text { April } 1 \\
\text { April } 27\end{array}$ \\
\hline 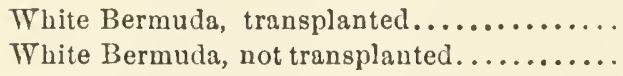 & $\begin{array}{ll}5.5 & \prime \\
5 & \prime\end{array}$ & $\begin{array}{l}\text { April } 15 \\
\text { April } 30\end{array}$ \\
\hline $\begin{array}{l}\text { Louisiana or Creole, transplanted } . . . \ldots \ldots \ldots \\
\text { Louisiana or Creole, not transplanted....... }\end{array}$ & $\begin{array}{ll}3 & \text { “ } \\
2.5 & \text { “ }\end{array}$ & $\begin{array}{l}\text { April } 25 \\
\text { April } 25\end{array}$ \\
\hline $\begin{array}{l}\text { Prize Taker, transplanted.................. } \\
\text { Prize Taker, not transplanted............ }\end{array}$ & $\begin{array}{ll}7.8 & \text { “ } \\
8 & \text { “ }\end{array}$ & $\begin{array}{l}\text { May } 25 \\
\text { May } 30\end{array}$ \\
\hline
\end{tabular}

It will be seen by this that in two cases the average weight was in. creased, and also the bulk matured earlier, besides this the nearly perfect stand insured by transplanting gave a much increased total yield per given length of row. These seeds were sown the last of August, 1893, and the plants transplanted when less than one-fourtl inch in diameter.

Fertilizers. 239. Q. Why do commercial fertilizers give the best results in wet seasons?

A. In wet seasons the repeated and abundant rains completely solve the component parts, so that neither in a dry state nor in half solved con. dition can they burn the rootlets.

Germination. 240. Q. Why is it that fresh seeds do not germinate as quickly as old seeds?

A. Some old seeds being perfectly dry are more susceptible to a less degree of moisture, consequently sprout quickly.

Vitality of Seeds.

241. Q. To what age do seeds retain their vitality?

A. That is a hard question to answer, as so much depends upon conditions of moisture, heat and soil-but as a rule vegetable seeds are entirely dead in eight years for cabbage, turnip and beet; four years for carrot, parsley, spinach ; five years for peas, beans, cucumber, squash, melons ; three years for peppers, egg plant, okra, corn.

Old Seeds Preferred.

242. Q. Why do some experienced gardeners prefer old seeds to fresh ones?

A. Old seeds having less physical force do not develop such vigorous plants-do not grow so rampant, and in the case of melons, squashes, cucumbers, they do not cover so much ground, while setting more fruit.

* Twenty days ahead of the Creole, and four and a half ounces against three ounces. 
243. Q. After a field is inoculated by bringing to it and incorporating soil with its surface soil some soil from another field, known to be inhabited Inoculation. by bacteria or microbes, what is the subsequent action?

A. The bacteria or organisms, if they be the right kind, cause, by some unknown process, the roots of the plants to develop minute nodules or tubercles, which, by some action, absorb nitrogen from the air and hold it. Four-fifths of the atmosphere is nitrogen. Consequently there is an unlimited supply, and if this new scientific discovery can be more thoroughly understood the entire system of agriculture may be revolutionized as completely as electricity has overturned former systems now obso. lete.

244. Q. Are wrinkled and flattened varieties of peas sweeter and more Peas. delicate than smooth round-seeded sorts?

A. The shriveled form of certain pea seed is indicative of a sugary quality, just as the shriveled grains of sugar-corn distinguish its quality from the more starchy field corns. Many of the wrinkled peas possess a shelly hull, which, to some people, make them less desirable than the Landreth Extra Early or the Bloomsdale pea. Wrinkled half-flat peas never seem to possess the same germinative force as hard round peas.

245. Q. What are the best plants for green manuring?

Green

A. All vigorous growers, which can be plowed under, have a decided Manuring. fertilizing influence upon soil, as the turning under returns to the upper soil all that the plant had drawn from depths below ; but if to this can be added a stock of fertility derived from the air, immense gain is made. Now this can be realized by growing plants of the leguminous family, as Red clover, Crimson clover, Alfalfa, Cow peas, lupins, all of which, beside being potash finders, have the faculty of drawing nitrogen from the air, and adding to the soil that which it did not possess before.

246. Q. Why is inoculation of soils advised?

A. To start a growth of bacteria, such as desired. One of the latest dis- Inoculation. coveries in agriculture is that different kinds of plants, notably those of the leguminous family, are aided in their growth by distinct forms of bacteria or microbes. Now, a field which has had upon it a crop of beans, continues for a time to support the bean microbe, but beans sown upon a new field, however rich in potash or phosphoric acid, may want - nitrogen, which can be obtained in considerable quantity from the air if plenty of microbes be present in the soil. By inoculating this new field through a top-dressing of soil from the old bean field, the development of microbes can be greatly advanced and the bean crop enlarged through nitrogen stolen from the air.

247. Q. Is the greatest productiveness found in green or wax-podded Beans. beans?

A. As a rule, in green-podded sorts; but some wax pods are exceedingly prolific, but when most so it is at a loss of quality.

248. Q. How can I kill crows and sparrows?

A. Soak corn in strychnine water. 
Beans.

Corn.

Onion Sets.

Asparagus

Bug.

Fungicides.

Iusecticiales.

Frungi.

Iusecticides.

Lime.

Suit.

Iingi.
249. Q. Which is superior in quality, a round green-podded bean or a wax-podded bean?

A. Tastes vary. The writer thinks a wax pod always tough.

250. Q. Which is the best sugar corn for an all-round sort?

A. The Landreth and Stowell's Evergreen.

251. Q. Does freezing injure onion sets?

A. Sets kept throughout winter in the latitude of Philadelphia are always frozen, and are not injured under careful handling, but should not be handled when the frost is coming out of them. If received in frozen condition spread them out to thaw.

252. Q. Is there any application which I can make to drive off the asparagus beetle from my young asparagus beds ?

A. Lime dust applied when the dew is on.

253. Q. What are the most generally used fungicides?

A. Compounds of copper and sulphur, particularly ; ammoniacal car. bonates of copper and Bordeaux mixture.

254. Q. Why do some so-called insecticides fail to be effective?

A. Probably because applied without any knowledge of the nature of the insects desired to destroy; for instance, insects which eat their food can be poisoned by mineral applications to the foliage, but insects which feed upon the juice of plants obtained by puncturing the skin cannot be poisoned by outward applications. The latter can only be destroyed by an application of something which will clog up their breathing pores.

255. Q. What fungi give the most trouble to the farmer and gardener?

A. Those occurring on the potato, onion, turnip, cabbage, corn, clover, wheat. A rotation of crops is effective in overcoming a fungus attack, as one which destroys plants of the cabbage family seldom attacks plants of a distinct genus, as, for instance, the onion or potato.

256. Q. What are the leading insecticides?

A. Compounds of arsenic, as Paris green and London purple; oils and soaps, tobacco dust, sulphur, red pepper.

257. Q. Is lime a good fertilizer?

A. Not of very much direct value, but of great importance in rendering available plant foods already in the soil. Lime also preserves the particles of soil in a separate coagulated condition, making heavy soils friable and pervious to water. It also promotes the formation of nitrates in the soil.

258. Q. Is common salt valuable as a manure?

A. No, not primarily; but it may on some soils have a good effect in helping to set free more important constituents. It is also useful for destroying insects or grubs.

259. Q. What is this fungi about which so much is now said by the scientific papers?

A. It is generally a parasitic growth, popularly termed mildew, mold, smut, blight or rust. Some of these growths can be prevented, others pal. liated and sometimes cured. As a rule, the smallest portions are self- 
productive if not destroyed, for instance, portions of the potato fungus, too small to be seen through a microscope, so small that figures cannot express their minuteness, are so potent with life that every atom will grow under favorable conditions; and the spores or reproductive parts of the putrefactive fungus of the lettuce plant are so small as to take 1000 to equal the size of the foot of a house fly.

260. Q. Is a collard a cabbage, and what is its history?

Collard.

A. Certainly it is one of the cabbage family, just as is the caulifiower or Brussels sprouts. It has bcen cultivated in the cotton States for a century. It may have been derived from a good heading cabbage, or it may, as is most probable, have been one of the Cow cabbages, common in parts of France-possibly brought over by early French settlers.

261. Q. From whence came most of the cultivated species of plants? Origin of

A. From Europe and Western Asia. The United States has furnished Plants. very few. Maize or Indian corn, the Jerusalem artichoke, and the gourds being the only important ones.

262. Q. I notice the main stems of my lima bean vines are all twisted. Lima Beans. Is that a healthy condition?

A. It is perfectly natural, as all twining plants have their main stems twisted upon the axis of the stem and in the same direction as they turn around supports. The extent of such stem twisting is increased or diminished according as the supporting stock or pole is rough or smooth. The rougher it is the more the new stem twists. Ordinarily, there is one twist of the stem for each spiral turn around a support, but sometimes much more.

263. Q. Can I make good hay out of oats cut when in green condition? Oats Hay.

A. Excellent, if dried properly and got under cover without rain. It should be cut before showing the seed, otherwise the growth becomes so bulky, that cut and laying upon the ground, it cannot be expected to dry, except under such dry and hot conditions as almost impossible to anticipate.

264. Q. I am offered at a Roanoke river fishery 100,000 herring. Are Fish Manure. they of value?

A. Very fertilizing, but very temporary in effect. Only good for one year. On our Jersey farm we have used 250,000 herring a year, and on our Virginia farm we have used 10,000,000 menhaden a year-a similar fish. Thirty to forty thousand broadcasted to the acre and plowed under four inches. Some farmers put two fish to a hill of corn.

265. Q. What is the best grass for planting on sand hills to prevent sand Grass. blowing?

A. Arundo Arenaria, a Dutch grass, planted extensively on the sand dunes of Holland.

266. Q. My beet field is very spotty, that is, uneven in the stand; the vitality. appearance indicating that there was a want of vitality in the seed, that is, the germination was very poor?

A. If the seed sown upon your field failed in all parts of it to germi- 
nate, then the seed might have been deficient in vitality. But, as you say it is spotty, it indicates a cause not attributable to the seed, but possibly to poor tillage, poor sowing, unfavorable conditions of rain fall, heat or cold, or possibly to insects over or under ground. If one foot of row was good, so should have been a thousand feet, for all the good seed could not have got into one place.

Melon Mildew.

Potatoes Growing.

Weeds.

Twining of Beans.

Toads.

\section{Climbing} Plants.

\section{Cause of}

Climbing.

\section{Spring}

ivleat.

26\%. Q. Is mildew common to muskmelons? Mine are covered with it.

A. Yes. Something like grape mildew. It can be held in check by spraying with Bordeaux mixture.

268. Q. My potatoes stored in cellar have many of them dereloped new young potatoes of an inch in size. What is the cause of this?

A. Probably heat and moisture. It is an old practice in England to force such an abnormal growth. In under-glass experiments with potatoes it is quite common for potato eyes to at once produce small but perfect tubers.

266. Q. How many varieties of weeds are there to annoy the farmer?

A. The New Jersey State Agricultural College exhibited at the Chicago Fair 751 species, and that did not comprise one-half of what exist in the United States.

270. Q. Why do beans and other climbing plants twist contrary to the course of the sun?

A. You are mistaken, as all do not twist the same. Among those twisting against the sun are Garden Pole beans, morning glory, jas. minum, wistaria, clematis. Among those twisting with the sun are the hop vine, honeysuckle, and many others, and some climbers go in both directions, as the nasturtium.

271. Q. My garden is infested by toads. Do you advise me to kill them?

A. No! They don't harm you or any of your vegetables or flowers, but, to the contrary, eat thousands of insects which might be very destructive. In France, gardeners pay twenty-five cents apiece for them as insect exterminators.

272. Q. How many classes of climbing plants are there?

A. Four classes : 1. Those which twine spirally round a support, as a Lima bean. 2. Those which possess irritable organs, which, when they touch any object, clasp it, as a clematis. 3. Those which climb up by means of hooks, as cucumbers. 4. Those which climb by rootlets, as the ivy.

273. Q. What causes the Lima bean, for instance, to climb a pole?

A. The nerve force seems to be centred in the last formed internodethe previously formed one losing its disposition to travel with or against the sun. What causes the movement it is impossible to say.

274. Q. Can I grow in my section of Georgia a crop of Minnesota Spring wheat?

A. No ; not as a Spring-sown crop, but it might do well as an Autumn crop same as Winter wheat. Many crops of an annual habit can be 
turned to a biennial habit-for instance, as a Winter oat treated just like wheat.

275. Q. What is the nature of the dark rusty spots which are thickly Melon Fungi. appearing on my watermelons, both foliage and fruit?

A. It is probably a fungus similar with that which spots bean pods, and if so, is quite contagious. Young plants can be sprayed with Bordeaux mixture, but it is difficult to arrest it even then, as the liquid caunot be thoroughly applied to the under sides of the foliage. On a strongly developed crop nothing can be done, as it is impossible to spray the under parts of such a mass of foliage laying almost on the ground.

276. Q. I want to try a good native Southern grass. What do you rexas recommend?

Blue Grass.

A. An American perennial grass not generally known but of admirable character for Southern sections, is the Texas Blue grass (Poa arachnifera), discovered on the prairies of that State in 1853. It blossoms there about the last of March and ripens its seed about the middle of April. Its habit in Southern States is much stronger than Kentucky Blue grass. In Texas, under the severest droughts, it sometimes lags a little, but after Autumn rains quickly springs into most vigorous growth and continues to grow all Winter. It makes a strong top growth for hay and a matted sod standing continued pasturing. It roots deeply and spreads rapidly by buds from long, strong, underground stems, which by their vigor resist the encroachment of Bermuda grass. Once established it will continue to stand for a lifetime. It is best propagated by cuttings of the roots, 20,000 set to the acre, or say one to each two square feet. Roots cost about $\$ 1.00$ per 1000 , seed about $\$ 2.00$ per pound, six pounds being sown to the acre.

277. Q. What is Bermuda grass? A. Botanically it is known as Cynodon dactylon and is a creeping per-Grass. ennial, bearing long, leafless fiower stalks, abundant but small foliage, and producing a mat of under-ground stems and superficial runners. It is not a native of Bermuda, but of Southern Europe. It is difficult to grow it from seed. Consequently best propagated by roots-every rootcutting of an inch will produce a plant. In the Southern States on good land it is one of the best hay grasses. It is very difficult to eradicate and often becomes a great nuisance.

278. Q. What is Johnson grass?

A. It is known as Sorghum holepense, a native of Africa. Its chief Grass. value is in regions where other grasses fail, but it must be cut young and often to be of value. It is difficult to eradicate, close pasturing being a means of killing it out. It should only be planted in waste places or where wanted permanently.

279. Q. What is Crab grass?

A. Botanically Panicum sanguinale, a native of Europe, but now comBermuda mon in all the Southern States. It produces long, under-ground, horizontal roots, often five and six feet long, rooting and branching at every 
joint. The flower stalks rise to a height of three feet. It is a grass to be dreaded as very difficult of eradication. It flourishes under hot sun and often on poor soils, gives fair pasturage when other sorts of grass are dried up.

Guinea Grass. 280. Q. What is Guinea grass?

A. Botanically it is called Panicum maximum, and is a native of Africa and cultivated extensively in the West Indies. Very susceptible to frost, and only ripens seed in the tropics. It is a large hay producer, reaching a height of six to seven feet. The seed resembles millet.

Ferbs. 281. Q. My herbs this year don't seem to possess the usual aromawhy is it?

A. The aroma is strongest in hot, dry Summers-when they grow vig. orously under effects of abundant rains they possess little aroma.

Sports.

282. Q. Why are not more of our ornamental plants and fruits grown from seed?

A. Because ofttimes they produce very little seed or none at all, but more especially because they are bud propagations, not the results of evo. lution or watchful and slow breeding. They are generally sports without heredity. In some of these cases, where the subject of heredity has been closely followed up for years, the seed produces like parent-for instance, among fruits many forms of Russian apples, and some peaches, grapes, plums and quinces.

Nitrogen. 283. Q. How can I make my pole beans run more freely?

A. Use nitrogen as a manure-apply it in the form of dried meat, blood, fish or guano.

Potash.

Grasses.

284. Q. How can I keep my beans and peas more dwarf?

A. Omit nitrogenous manures and fertilize with potash.

285. Q. How many grasses are there?

A. Over 3000 plants of the grass family are known and described, the greater part of no value. The list of grass seeds offered for sale in various countries and recommended for forage numbers about 200 sorts.

Cucumber I3lossoms.

256. Q. My cucumber vines set very few fruit compared with the number of blossoms. How is this ?

A. In cucumbers the sexes occur in distinct flowers and it is only the female flowers which develop fruit. In cucumbers, blossoms occur at every joint, and these are only three to four inches apart, often three blossoms at a joint, and quite 100 to 200 blossoms to a single vine, and presuming that one-third were female a cultirator might look for an enormous production, but very few of the female flowers become pollenized and fruitful.

Tomato.

287. Q. Can I take up some of my tomato plants growing in the field and keep them over the Winter for setting out next Spring?

A. You might succeed, but the chances are against you, as the plants are in unsuitable condition for removal. Tomato plants, however, have been known to live for years in a greenhouse, and in the West Indies 
they flourish out of doors like grape vines. Many annual plants become biennial in the tropics, for example, the pepper and egg plant.

288. Q. What is the relative proportion of male and female blossoms Squash. on the bush squash?

A. About five males to one female. The flowers of the male are larger and borne on long fool stalks and after fully distending fall off, leaving the fool stalks behind.

289. Q. I fear I have given too big a dose of fertilizer to my pea crop, overas the foliage is turning yellow. What do you advise me to do to rectify manuring. my mistake?

A. Constant cultivation is the only ameliorative course you can adoptits object being to keep the soil friable so that not only rain but dew, fog and atmospheric moisture can more fully enter the soil to solve the fertil. izer, and the more it is diluted the less burning its results. Commercial fertilizers seldom burn in a rainy season, but always are likely to do so in a dry one.

290. Q. My tomato plants are wilting and curling and turning brown. Tomato Am I going to lose my crop?

Diseases.

A. Your plants are evidently suffering from a fnngus growth-a microscopic vegetation which is eating up the fleshy matter of the leaves and arresting all development. Spraying with fungicides is effective when you can reach the under side of the leaves, but otherwise it is only half done.

291. Q. I find that seeds bearing the same name, that is, sold under Names the same label, differ very widely. Why are not particular seeds the of Seed. same the world over? Why don't one seed merchant sell the same stock as another?

A. They differ because some are grown in Germany, some in France, some in England or Scotland, or if American, some are produced in the Eastern, others in the Central, and others in the Western or Pacific States. All these localities possess different soils and climates, and consequently there is naturally developed a variation in size, color, flower and desirability, and yet they all are issued under a given name-for instance, the seed of Evergreen corn grown in Pennsylvania or New England will produce a plant of distinct characteristics from plants grown from Illinois stock, Kansas or Michigan stock, and yet it is all sold as Evergreen.

292. Q. What shall I do to rid my garden of earth worms ?

A. The common earth worm does no harm, in fact is rather an advan-Worms. tage, as it bores air passages throughout the soil. It can be destroyed by the application of lime.

293. Q. Why are round-podded beans preferred to flat pods?

A. Round pods are generally solid or meaty and free or comparatively Beans. free from string, but flat pods are often more or less hollow or windy, generally stringy and nearly always thin, and when examined closely possess sides more or less like muslin. 
Bean Rust. 294. Q. The pods at one end of my bean patcl are spotted with red rust ; the greater part of the patch is free from rust. How do you explain this?

A. Possibly the end where the rust appears is lower, and consequently damper, or, perhaps, it is in the shade of trees or other obstruc. tion to free circulation of air. The rust is a fungus.

Potato Importations.

295. Q. What is the extent of annual importations of potatoes?

A. During the year, ending June, 1894, the importations were as follows :

\begin{tabular}{|c|c|c|}
\hline & Bushels. & Values. \\
\hline Belgium $\ldots \ldots \ldots \ldots \ldots \ldots \ldots \ldots \ldots \ldots \ldots \ldots \ldots$ & 51,720 & $\$ 16,844$ \\
\hline Germany.$\ldots \ldots \ldots \ldots \ldots \ldots \ldots \ldots \ldots \ldots \ldots \ldots$ & 41,662 & 15,354 \\
\hline 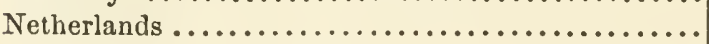 & 28,347 & 15,607 \\
\hline 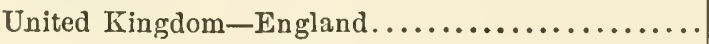 & 295,435 & 117,288 \\
\hline 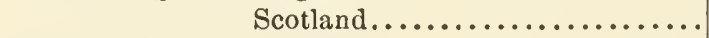 & $1,671,239$ & 737,531 \\
\hline Ireland............... & 28,540 & 10,872 \\
\hline 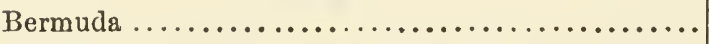 & 64,993 & 109,122 \\
\hline 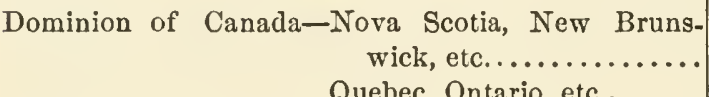 & 596,799 & 169,086 \\
\hline MIexico $\ldots \ldots \ldots \ldots \ldots \ldots \ldots \ldots \ldots \ldots \ldots \ldots \ldots$ & 1,235 & 1,454 \\
\hline 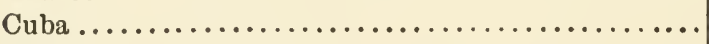 & 28,084 & 17,351 \\
\hline 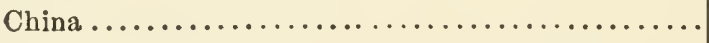 & 1,187 & 252 \\
\hline 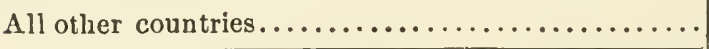 & 5,317 & 3,080 \\
\hline & $3,002,578$ & $\$ 1,277,194$ \\
\hline
\end{tabular}

Conch Grass. 296. Q. What is conch grass or quack?

A. Agropyrum repens, a nuisance found in nearly all the Northern States, a first-cousin to the crab grass of the South. It forms a dense sod, its far-reaching horizontal roots having short joints, which throw out root fibres and leaf stalks. Its foliage and roots are succulent and nutritious, but it is a pest of the first order.

Japan

Clover.

Alfalfa.

Peach

Yellows.

297. Q. What is Japan clover?

A. Lespedeza striata, introduced about 1850 , from China. It is a quick.growing annual, killed by frost. Does best on clay lands, especially on bottoms, where it is a good hay producer. It seeds itself.

298. Q. What is Alfalfa?

A. It is Medicago sativa botanically. Also known as Lucerne and used for cuttting almost entirely, as it is not adapted for pasturage, cattle eating it off the crown. According to soil and location it continues in vigor from three to ten years. It is adapted to dry climates. Overflow kills it. 299. Q. Can I cure my peach trees, which appear to be affected with the yellows, by the application of wood ashes?

A. No ; manuring the soil will not stop the spread of the disease. 
300. Q. Where can I purchase spraying apparatus and get formulas for spraying insecticide?

Apparatus.

A. From the publishers of this pamphlet.

301. Q. In your Catalogue, you sometimes refer to tillage, then to cul-Tillage. tivation. What is the difference?

A. To plow, to dig, to harrow, before the crop is planted, is to till.

The earth is tilled, but the crop is cultivated.

302. Q. What leaf fibre plants can be grown successfully in the Gulf Fibre Plants. States ?

A. The Agave rigida or true sisal hemp, the Agave decipiens or false sisal hemp, the Agave Americana or century plant, Ananassa sativa or pineapple, Sansevieria or bowstring hemp, Phormium or New Zealand flax, Pucca filamentosa or bear grass.

303. Q. How many experimental stations are there in the United States? Experimen-

A. About fifty. Some States having two, others more.

304. Q. On what crops is nitrate of soda especially effective.

tal Stations.

A. As an auxiliary to stable manure it is efficient on all crops, but it Soda.

is especially profitable on the crops most expensive to grow, on account of excessive labor, as by its use there is more certainly assured a larger return.

305. Q. A seed-grower writes of male cabbage plants failing to pro-Sexes in duce heads. Is this so?

Cabbage.

A. It is a ridiculous statement, as there is no such thing as a male cabbage plant, the two sexes occurring in the same flower. Cabbage plants which fail to head, if the conditions of season, climate and soil are favorable, might properly be termed abortive.

306. Q. I have in my watermelon field a twenty-pound melon, one half Parti-colored deep green, the other half lemon yellow-the dividing line running from Watermelon. blossom end to stem end. How is this?

A. It may be the effect of a pumpkin hybridization the previous year of a double or twin watermelon blossom, or it may be only a common freak or sport of nature-a familiar example being found in some gourds, which are always half green and half yellow.

307. Q. If the flower of a watermelon is pollenized from the flower of Hybrid a pumpkin, and the cross be effective, is the fruit resulting an obvious Melons. hybrid?

A. No; it is little affected if any-the hybridization being confined to the seed, which planted the next year shows the mixture.

308. Q. Why is it that every year about lualf of my spinach plants die sex in without producing seed?

Spinach.

A. The half which die are the male plants, which dry up after perfecting their bloom. The female plants only produce seed, and these live for a month after the male plants have disappeared.

309. Q. Not one-half of the blossoms on my cucumber vines ever set Sex in fruit. Why is this?

A. The sexes occur in distinct flowers-the male never produces fruit, 
and only those female flowers which are fertilized or pollenized by contact with male flowers or through the agency of the wind or of insects.

Pumpkin or Squash.

Tea Plant.
310. Q. What is the difference between a pumpkin and a squash ?

A. A pumpkin never develops a rind hard as wood, while a squash does.

311. Q. Can the tea plant be grown successfully in the United States?

A. Yes, the plant can be grown very successfully in some of the Cotton States, but in this country labor is very costly as compared with the cheap labor of China. In 1790, David Landreth had growing near Philadelphia a hedge of tea plants which stood for years.

First Horticultural America?

Society.

A. In 1828, the Philadelphia Horticultural Society, of which David Landreth was Secretary.

First

Agricultural Society.

Tomatoes.

Salt.

\section{Cutting}

I.ettuce.

Coreless

Catrot.

Color in Vegetables.

Dates for Seeding.

313. Q. At what date was the first Agricultural Society established in America?

A. In 1785, the Philadelphia Society for the Promotion of Agriculture.

314. Q. Are all tomatoes derived from the same species?

A. No; the best of the large sorts in cultivation have been derived from the Esculentum, a sort divided into four or five cells by intervening partitions. The pear-shaped varieties are derived from the Pyriforme, a sort of two cells. The grape or current sorts from the Cerasiforme, of two cells.

315. Q. Will salt applied to my fields drive away corn grubs?

A. Yes; very frequently most efficient in arresting ravages of chinch bugs on wheat, cut worms on corn, but it should be applied before the crop is planted-six or seven bushels to the acre.

316. Q. You describe a lettuce as a cutting sort. What do you imply by that expression?

A. A variety producing a mass of loose leaves-not a heading sortgenerally an early variety.

317. Q. What do you mean by coreless as applied to a carrot?

A. The usual types of carrots contain a woody centre, from off which the soft outer shell can be removed. In the case of the coreless varictics this character is nearly eliminated-the whole mass being soft.

318. Q. Are not Yellow Belgian carrots more nutritious for cattle feeding than White Belgian?

A. As a rule vegetables of deep colors are considered richer than those without color, but it is possibly a fiction. The Sugar beet is white, the Bassano beet is white, both of exceeding sweetness.

319. Q. Is there any general guide to indicate the proper periods for sowing seeds, a guide good for all sections?

A. It would be difficult, if not impossible, to indicate a guide for sow ing in the Southern States, but in the North the blooming of trees affords a good indication. The periods for the first Spring sowing might be named as follows : 
1st Period........The blooming of the peach........ Peas.

2d Period........The blooming of the cherry.........Peas,

Periods for

Sowing Seeds.

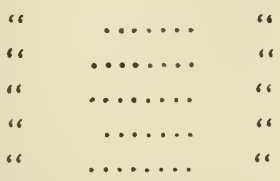

.......Spinach,

........Lettuce,

........ Corn salad,

........ Onion sets,

.......Asparagus roots.

3d Period.......The blooming of the pear..........All the a bove, with addition of

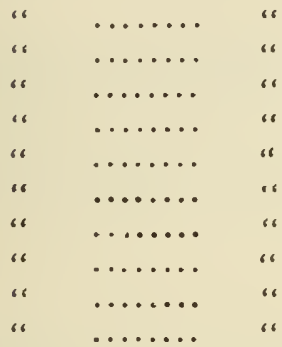

" $\quad$. . . . . . . Radish,

" $\quad$.......... Carrot,

"..... ... Beet,

" $\quad$.......... Mrustard,

" $\quad$.......... Onion seed,

“

، $\quad$......... Tomato seed,

" ......... Cabbage,

" ..........Parsnip.

4th Period........ The blooming of the apple.

le.......All the preceding,

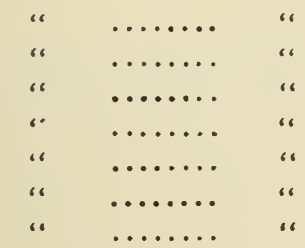

\begin{tabular}{|c|c|}
\hline ، & \\
\hline & ........ Salsify, \\
\hline & .......Beans, \\
\hline " & ......Corn, \\
\hline “؛ & ....Cucumber, \\
\hline “ & ........Melon, \\
\hline “ & .......Pumpkin, \\
\hline
\end{tabular}

320. Q. What soils are best adapted to tobacco culture?

Tobacco

A. Like all other cultivated plants, tobacco has its various forms, quali-Soils.

ties and assortments, and the progressive tobacco grower plants only those the most profitable to him, as respects soil and his market, both of which must be studied. Red clay subsoils, with rich top soils, generally produce the best dark rich export tobacco. Soils composed of sand or gravel, with subsoil of light brown or red clay, develop the best stemming tobacco and fillers. Flat lowlands of alluvial soil give the best cigar types. Limestone soils, dark and rich, are the only soils adapted to White Burleigh, which, when well grown, is very choice. Slaty soils produce the best quality of the yellow wrapping sorts. The list of socalled varieties of tobacco runs up into hundreds, many the result only of a difference in soil. The publishers have selected a limited number of varieties of such as will meet any requirement under the classification of adaptability. The publishers solicit orders for seed, believing their stocks to be of excellence, and knowing a change of seed, when good stock can be obtained, is generally a great advantage to the planter. 
Turnip Fly. 321. Q. Why did my second sowing of turnip seed utterly fail to come up when my first sowing from the same bag did perfectly well ?

A. Possibly the second sowing was eaten off by the turnip fly when it was only one-twentieth $\left(\frac{1}{2 \sigma}\right)$ of an inch out of the ground, and was killed before you were aware it had sprouted.

Top Onions.

322. Q. Are there two kinds of top onions?

A. Yes; those with single eyes producing one large onion and those with several eyes splitting up into a number of small bulbs. Consequently inferior to the larger single type variety.

323. Q. Have pole beans any advantage over bush beans?

A. It is more expensive to prepare to grow pole beans, as the poles are costly and the vines need to be tied up three or four times; but the product is larger, consequently the general results are in favor of the pole varieties, especially as the pole sorts, with two or three exceptions, continue to bear till killed by frost, while the bush beans produce their entire crop in a very limited period.

Paris Green. 324. Q. Have vine crops different degrees of power of resistance to the burning effect of Paris green ?

A. Yes; cantaloupes the least-next watermelons, followed by pump. kins-the hardiest being squash.

Melon Bugs. $\quad 325$. Q. What is best remedy for bugs on melons?

A. This is a difficult question. Lots of preparations will kill bugs dead as Cresar, but if put on strong enough to finish the insects they either kill the plants or burn them. It is difficult to strike the happy medium.

Paris green is as good as any bug poison, but it should be mixed with something as a dilutant, as land plaster-say one part of Paris green to 100 of plaster or flour-anything stronger will burn the leaves of the plants. Applications may be made at intervals of four days. For the melon louse use kerosene emulsion or whale oil soap.

326. Q. How can I test the vitality of seeds?

A. Many ways; but nonealtogether satisfactory, for results to-day may be positively changed next week or next month, so much depending upon the peculiar conditions of moisture and heat, or the fluctuations of the same. Again, seeds have their periods of sprouting-sometimes those which fail in January will do well in April. Tests of vitality can be made by counting out 100 seeds just as they run, good and bad, and testing them to develop the percentage of seeds which will sprout. This can be done between solidified bats of cotton kept damp in a saucer partly filled with water-or on seed-testing trays manufactured for the purpose, or in pots filled with carth and kept in proper temperature or on the earth benches of a greenhouse. Vitality tests out of doors are very unsatisfactory, as dashing rains arc apt to defeat all calculations.

327. Q. For small vegetable gardens do you advise the use of suable manure or commercial fertilizer?

A. Stable manure every time, as it comprehends all the necessary fer. 
tilizing ingredients and loosens and aerates the soil. Soils too frequently treated with commercial fertilizer become compacted.

328. Q. Should I plant my radish seed during the increase or decline of Moon the moon ?

A. The moon has no influence upon vegetation. That is an exploded idea too dead to be resurrected.

329. Q. Why is there more fungus growth some seasons than others? Fungi.

A. Nearly all fungus growths can, in a general way, be likened to a mushroom growth, and the mushroom, it is well known, flourishes under conditions of moisture. So, likewise, fungus developments are most common in wet seasons.

330. Q. Why are insects more destructive to vegetables some seasons Insects. than others?

A. Insects destructive to vegetables always appear in greater numbers after a mild Winter. The larvæ of such insects lay dormant in the soil over Winter, and very hard frost kills millions. While under the conditions of a mild Winter all live and show themselves in Spring or Summer.

331. Q. Is a wet or dry season the most profitable to the practical Most market gardener?

A. A dry one, as a wet season smiles alike on both good and poor mana- Seasons. gers, while in a dry season, when so many crops fail, the good manager, having a variety of crops put in at different periods and possessing practical experience in meeting difficultics as they arise, succeeds in obtaining good crops from some portions of his land and high prices for his products.

332. Q. Is the perennial Lima bean a desirable sort for garden cultiva-Perennial tion ?

Lima.

A. It does not possess any particular merit beyond novelty. It develops a small bushy plant of slender and procumbent character; pods four to five inches long and depressed between the seeds, which, when dry, are oblong and thick and of good quality. It is late and a shy bearer. It has the peculiar character of keeping the cotyledons under the earth. Other Limas elevate them.

333. Q. How many forms of Lima beans are there in general cultivation ? Lima Beans.

A. Two very distinct classes, the pole and the bush. The pole or climbing class can be divided into the Large Lima, the Challenger Lima, King of Garden Lima, and the Carolina, both white, yellow, spotted and black. The bush or dwarf class can be divided into the Dwarf Carolina in three colors, white, yellow, spotted; the Potato Lima, or Dreer's Dwarf, or Kumerle, the Burpee Lima, and the Perennial Lima.

334. Q. Can the Large Lima bean be kept alive so that the same roots Perennial will produce a crop the second Summer?

Beans.

A. It is doubtful if it could be done, except in Southern Florida. In California, the Perennial Lima and the White Dutch Runner beans, which both have fleshy roots, often live over Winter, and send up from near the surface a second growth of vines, producing a second crop of pods.

335. Q. Why is a snap short or stringless bean called a string bean? ' String Beans.

A. Simply through force of habit or custom. The bean of years ago, 
all having been stringy, which undesirable quality has, by intense selec. tion, been eliminated, the bost "string beans" now not possessing any strings, but snapping off short like sticks of glass.

Butter Beans. 336. Q. What are "butter" beans?

A. At the present day the term butter beans is applied to yellow waxpodded sorts, as they somewhat resemble butter in color; but years ago the term was only applied to the Lima bean, as it was usually served with a butter sauce.

Germination. 337. Q. Do seeds differ much in sprouting qualities?

A. Yes; very much. There is a great variation in germinative power under diverse conditions of soil as respect heat and cold, excessive damp. ness or dryness. Most seeds make but one effort to start or germinate, that is, they start, and, if unchecked, continue to grow freely, or, perhaps, drag along if not arrested entirely ; but some others, wheat, for ex. ample, can be stopped entirely by cold or heat, excessive wet or drought, and, upon the return of favorable conditions, start again and again, four or five times repeated.

Bermuda

Grass.

338. Q. What is the best grass I can use in Florida to stop my land from washing?

A. Bermuda grass, planted by cutting small pieces of sod and inserting it. Cow Peas. 339. Q. How do you recommend Cow peas to be used ?

A. 1. The vines can be plowed under when green. 2. The vines can be cut and dried for cattle food. 3. The vines can be allowed to dry and produce a crop of seed. 4. The vines can be allowed to dry and fall on the surface and lay all Winter.

Cotton

340. Q. What is the best manure for cotton?

Fertilizers. A. Cotton requires phosphoric acid, nitrogen and potash in the order named. Or for a crop of say 300 pounds of lint per acre say 50 pounds phosphoric acid, 20 pounds nitrogen, and 15 pounds potash. For the phosphoric acid, use commercial super-phosphates possessing a large quantity of soluble phosphoric acid ; for nitrogen, use dried blood, dried fisl, ground cotton seed; for potash, use muriate of potash.

Club Root. 341. Q. My cabbage has developed club root. Instruct me how to stop it from destroying the entire field ?

A. It cannot be stopped, as any application now would be too late. After the crop is off, apply 80 bushels of slacked lime per acre and 8 bushels of sålt.

Green 342. Q. What plants can $I$ best use for green manuring ?

Manuring. A. Cow pea, alfalfa, scarlet clover, melilotus, serradilla, lupine, vetch, rye, maize, sorghum, red clover.

343. Q. Name the situations where various grasses do best?

Grass Soils.

A. In special locations as on lowlands or mountain sides, or on special soils as sands, gravels, clays, loams, some sorts may, with advantage, be omitted and others added. Timothy, for example, a short-lived hay grass, does best on well-drained land and in northern latitudes. Red Top, a louger-lived sort, does better on moist land, even sustaining long- 
continued overflow. Orchard grass, on the other hand, a good, allaround sort, will grow on dry, sandy loam ; fairly well on poor clay and better on rich bottoms, so it be not overflowed, and it even endures the shade of trees.

344. Q. On what soil does Blue grass do best?

A. Blue grass doing best on limestone soils is not a good hay producer, as it is a light cropper, difficult to cut and harder to cure, but it is eminently a pasturage and lawn grass. It is an easy grower, flourishing for a limited time on gravels, bottoms and clays, while on limestone soils grazing fields have been known to remain in perfection for sixty years. It will not stand severe droughts, but resists any amount of frost, while continued pasturage only makes it better.

345. Q. What are the best grasses for pasturage?

A. Upon the length of time which it is contemplated to allow the pasturage to stand depends, to a large extent, the varieties of grass seeds to mix, as for example, Timothy, Italian Rye grass, Cocksfoot, White and Alsike clover, are all very quick to develop and suitable for a two or three years' shift, while for a longer term should be added Blue grass, Red Top, Foxtail, Tall Fescue, Perennial Rye, Lucerne and Red clover.

346. Q. How many grass seeds are in a pound?

Seeds to the

A. One who sets himself to estimate the number of seeds in a pound Pound. will soon come to a realization of the necessity for a perfect seed bed, that the small seeds be not lost in crevices or under clods, for he will find the seeds to number in a pound of Tall Fescue 250,000, Red clover 280,000, Orchard grass 600,000 , Timothy $1,250,000$, Blue grass 2,375,000, Rough Meadow 3,000,000 and Red Top 8,000,000. Can it be expected that over 10 per cent. of the seeds ever make a plant, considering the rough tillage and careless sowing of the ordinary farmer?

347. Q. Why do you advise the sowing of so much grass seed to the Grass acre?

A. Thin seeding of grass is a most serious mistake, as a poor stand of grass only leaves room for weeds to occupy the space. Consequently we advise a very liberal application of seed, for under the best conditions, as respects preparation of land, distribution of seed and covering, a large portion of the seed will get too deeply covered over to vegetate.

348. Q. How deep should grass seed be covered ?

A. Not more than one farmer in a hundred by his field practice shows Covering. any indication that he realizes the necessity of shallow covering of grass seeds, for they generally put on a harrow and cover to a depth of one to two and a half inches, delicate seeds not one-thirtieth of an inch in diameter. Certainly the greater part never shows a green blade, for farmers seldom stop to consider the delicate nature of the seeds they commit to rough, cloddy earth.

349. Q. Instruct me what mixture of grasses will do best in my section?

A. All prescriptions for grass seed mixtures are little more than generalities, for no one can compile a table or series of tables showing the varie- 
Grass Seed Prescription.

ties positively adapted to different localities, for soils even on adjoining fields frequently vary so much as to require an entire change in the varietics and proportions. How much more difieult to prescribe for unknown soils, some perhaps a thousand miles away. The geological constitution, rainfall, drainage, altitude and objects sought, whether for hay or grazing, all need to be studied. The best guide is the experience of others in one's location, but even that is often misleading, for we have grown grand crops of Timothy and Clover in a section of a Southern State, where the farmers seldom saved any hay, trusting almost entirely to corn fodderof course there.were no barnyards worthy of the name in that locality.

Heredity.

350. Q. Is there mueh dependence to be placed in heredity?

A. While heredity is a well-marked principle in vegetable life, there is a constant teudency to depart from established forws, sometimes for the better, oftener for the worse, for reversion is generally downward in the scale of excellence. The reversion may be in the form of a wild sport, or a distinct reproduction from a late or a very remote ancestor. Were it not for heredity the seed growers' labors would be in vain, but fortunately the man who finds a good thing in the greenhouse, flower garden, or veg. etable garden, or in the field, can seize upon it, and by the aid of heredity fix, after a time, its valuable qualities for the benefit of all. But it may be well to say he meets with many instances of curious reversion to original types.

Variability.

351. Q. Can the Market Gardener do anything to prevent variation from true types?

A. No. Every experienced seed grower knows that the purest crops will sometimes develop the wildest sports; for instance, a crop of cabbage of apparently absolute purity may produce a few plants like collards, the result alone of reversion. The seed grower is powerless to prevent this natural physiological freak, and the gardener who knows anything of seed production and vegetable variability deals more rationally with the seedsman than he who knows nothing of such matters, but thinks nature should produce plants all as much alike as nickels from the mint.

Market Gardening.

352. Q. What is the value of the Market Gardening industry in the United States?

A. Upward of $\$ 100,000,000$ is invested in this industry, the annual products reaching a value of over $\$ 75,000,000$, the product of over half a million acres of land. The annual expenditures for fertilizers being $\$ 10,000,000$, the number of hands employed being 250,000 . The number of horses and mules employed being 75,800. The value of the implements used being $\$ 8,971,000$. In the Pliladelphia district, which includes Pennsylvania, New Jersey and New York, there are employed 70,000 men at an average cost for daily wages of $\$ 1.19$; the annual production being of the value of $\$ 21,000,000$.

Cucumber 353. Q. What is the extent of cucumber pickling?

Salting.

$\Lambda$. While gardeners may have some idea of the extent of cucumber culture for sule as a vegetable, little is known about the development of 
its culture for salted pickles. Our neighbors over in New Jersey were for years the largest producers of cucumbers for salting, growing annually 200,000 bushels, but now, by reason of Western competition, not a quarter part of that quantity is grown. Long Island, in the East, is the largest producing section, the New York crops being estimated at 200,000,000 pickles. These pickles bring the farmer from 60 cents to $\$ 1.25$ per thousand. The Ohio Valley is the next important pickle section. After that, the country near the south end of Lake Michigan. These various crops of cucumber sections amount to about $1,500,000$ bushels of 300 to the bushel, consequently $450,000,000$ cucumbers. Large quantities are exported to Europe.

354. Q. How many cucumber pickles can be had from an acre?

A. A good crop of cucumbers when gathered of pickling size produces from 100 to 175 bushels to the acre. A bushel contains about 300 pickles.

Some cultivators have claimed to produce over 100,000 pickles to the acre. When pulling pickles the work should be done cautiously, that the vines be disturbed as little as possible, for if they be uninjured they will produce many successive pickings. The pickles should be slipped from the vine by the thumb and finger without raising or disturbing the vine.

355. Q. Can beet root sugar be made in the United States?

A. During the past fifty years a hundred efforts have been made to produce beet sugar in the United States, but nothing really practical, certainly nothing profitable, was accomplished till after 1880 . During the Summer of 1893 seven beet sugar factories were in operation in the United States, one in Virginia, two in Nebraska, one in Utah and three in Cali. fornia. The money invested in these several factories is estimated at $\$ 2,500,000$. In the Autumn of 1893 and Winter of 1894 the output of sugar from these seven factories was $45,000,000$ pounds.

356. Q. Is the canning of peas increasing?

A. The quantity of pea seed annually sown has reached vast dimen. sions, quite 250,000 bushels being annually planted. In the Chesapeake Bay district alone it is estimated that 40,000 to 50,000 bushels are sown each year on from 20,000 to 25,000 acres from which product 75 per cent. is put into cans. The quantity of product of peas greatly varies under conditions, sometimes 100 bushels of green pods to the acre being har- vested, at other times only thirty or forty. The canning of peas has developed on a par with that of tomatoes, the number of tin cans put up in the United States being estimated at $18,000,000$ to 20,000,000. The Baltimore city canners use annually about 400,000 bushels of shelled peas, which they put into 7,000,000 cans.

357. Q. Is there any machinery made for shelling green peas?

A. Formerly all peas for canning had to be picked from the vines by hand and shelled by hand. Some years ago machine shellers or pea hullers were invented for opening the green pods, 100 bushels an hour or 1000 bushels a day, and grading the soft peas into three classes according to size. These machines do the work better than when done by hand, 
and doing the work so quickly the peas are put through the process of canning before they take on a dry or soiled appearance, which is often the case when done by the slow system of hand shelling. But now the large growers never pull a green pod, but by machinery pull up the vines from the entire field when they are bearing the greatest number of developed pods, and then passing the vines through the machine break off the pods, open them, and grade the peas. Introduction.

358. Q. In what year were tomatoes generally introduced as a vegetable?

A. In this country tomatoes came into general use about 1845 , and have grown so rapidly in favor that no fruit or vegetable which can be named has to such a rate increased in cultivation, the fruit, either natural or canned, being used in all seasons-indeed, quite as much in Winter as in Summer.

Tomatoes were first packed in tin and glass by Mr. Harrison W. Crosby, at Lafayette College, $\mathrm{Pa}$,, in the year 1848 . He sold his product at fifty cents a can; now the price is seven cents-the result of the adoption of steam machinery and intense application to the cheapening of costs.

The canning of tomatoes has now reached enormous proportions. In $1894,138,000,000$ tins were put up, and the regetable, as it is classed, is in as common use during Winter as in Nidsummer.

Seasons for Vegetables.

Potatoes.

359. Q. What are the seasons for various vegetables?

A. Formerly esculent vegetables could be divided in to classes, as respects seasons of use, and a period named covering the time of sale of each class-as, for example, peas were only offered during May, June and July, and so with cucumbers, tomatoes, egg plants and beans; they all had their seasons, and, when they were past, only those people who had greenhouses could expect more until the return of the corresponding sea. son of the following year. But now that is a condition of the past, for Georgia and Florida, with their evergreen productiveness, have been able to revolutionize the old conditions by sending to the Northern cities, even when snowclad and icebound, the fruits of balmy Summer.

360. Q. Where do the earliest new potatoes come from?

A. Large quantities of new potatoes reach the markets of New York and Philadelphia from Bermuda, Charleston, Savannah, Florida, and still later, but before Northern crops mature, from Virginia and Maryland; and there is room for more, at paying prices, and they who present them early, of good sorts and in good condition, need not apprehend a want of customers.

Sweet Potato. 361. Q. What is the relation of the white potato to the sweet potato?

A. The white potato has become a product of the world, cultivated equally successfully from Chili to Alaska, from the Cape of Good Hope to Iceland. The sweet potato, on the other hand, belongs to a distinct botanical order; in fact, if one is a potato the other is not. The tubers of the white potato are underground branches, while the tubers of the sweet potato are enlarged roots. The sweet potato is very sugary as well 
as farinaceous. It appears to have been found both in tropical America and part of Asia. The early Spanish voyagers to America took it back with them to Spain, where it was cultivated as early as 1526 , or forty or fifty years earlier than the white potato.

362. Q. How many marketable ears of green corn should we get to the Corn. acre, and how long does it require from planting to marketing?

A. Of the medium and large varieties of sugar corn, 75 to 80 bushels, or 8000 to 9000 marketable ears can be raised to the acre. Corn when planted in Midsummer does not mature as quickly as when Spring planted, as the climatic conditions are not so favorable, not of such a forcing nature as the early Summer influences, hence from 10 to 15 days must be added to the calculation of the time required to develop a crop, for instance, the Evergreen Sugar corn, which, when planted, say May 15, will mature under usual conditions in 85 days, should be given 90 to 100 days as an Autumn crop.

363. Q. What is the extent of the corn canning interest?

A. The canning of corn for Winter use has become a most important Canningindustry, employing thousands of hands and a large capital invested in buildings and machinery. The number of tins put up during the Summer of 1893 was $93,000,000$, and it is expected that during the Summer of 1895 the number of cans may reach to 125,000,000. New York State cans the largest quantity, with Maine not far behind and Maryland as a third. The operations in the State of Maryland of growing the best vegetable sweet corn for canning have reached a most notable development. One Maryland farmer and canner alone purchasing for several years the seed corn to plant 1100 acres of his own land and 3400 acres of contracted crop grown by neighbors; every grain from which 4500 acres he put up in tin caus.

364. Q. What are the manufacturing uses of corn?

A. A large quantity of corn is used in making starch. This article is Corn. more generally used in the arts than is realized, for it enters in the filling of many woven fabrics, in the manufacture of candy, some candy being over half starch, in baking powders, paper and a thousand things as an adulterant, $250,000,000$ pounds of starch being annually consumed in various ways, and all of which, in this country, is made principally from potatoes, corn and some from wheat. About 10,000,000 bushels of corn are annually used in the manufacture of starch. A comparatively new use for corn is that for brewing or beer making, quite $30,000,000$ bushels being used annually. Corn used for brewing has first to be deprived of its cuticle and its germ to get rid of the native oil, for if over 2 per cent. of oil remains the corn is unfit for beer. The degerminating machines are very ingenious.

365. Q. What is the geographical centre of the corn-growing interest?

A. In 1829 the centre of production was this side of the Alleghenies. In 1839 over the mountain. In 1849 in Ohio. In 1889 in Illinois. In 1894 in Iowa. None of these districts which once led have fallen behind in 
production; only been eclipsed by the phenomenal production and extended areas of the newer States; for instance, Tennessee, which fifty yeare ago ranked first, now ranks only ninth, though its production of corn is double what it was then.

366. Q. How much corn is grown in Europe?

A. The growth of corn in Europe is steadily increasing, now reaching the quantity of $300,000,000$ bushels, or say one-seventh of that of the United States. The European countries producing the largest quantity are Austria IIungary, with 100,000,000 bushels, followed by France with $80,000,000$ bushels. In the Mediterranean countries there are annually sown many million acres in forage corn. The grain there does not reach perfection as in this country, for it is always imperfect in form and generally stained and moldy, for the climatic conditions of the nights there are not at all favorable to the ripening of the grain. The undeveloped and moldy grain when consumed for a length of time develops a disease, to treat which special hospitals have been established.

367. Q. When was the first vegetable analysis made?

A. The first accurate analysis of a vegetable was not made till the year 1810, and so late as 1838 the Göttingen Academy offered a prize for a sat. isfactory solution of the question whether the ingredients of the ashes are essential to vegetable growth. The last forty years have placed agriculture upon a scientific foundation, and the strides of development have been wonderful. The investigations of all scientific men, in these particular pursuits, have served to dispel ancient theories and develop a knowledge of the systems of germination, subsistence and growth.

368. Q. What are the essentials to plant subsistence?

A. It is, fortunately, the case that nearly every soil holds more or less of the inorganic parts essential to vegetable growth. They may be briefly enumerated as sulphates, phosphates, nitrates, chlorides and carbonates of potash, lime, magnesia, iron. Where an ingredient is deficient in quantity it can be readily aided by specific application. The time has come when every farmer must possess some knowledge of natural history; he must prepare himself, if he expects to follow his pursuit successfully, as much as does the mechanic or the professional man.

369. Q. After a market gardener purchases or rents his land, how much ready cash must he have per acre to properly work the land?

A. From Florida the reports of the necessary capital per acre in land or its rental (not of labor), fertilizers, tools, implements, seed and all the appliances, average ninety-five dollars; from Texas, forty-five; from Illinois, seventy dollars ; from the Norfolk district of Virginia the reports vary from seventy-five to one hundred and twenty-five dollars, according to location, and from Long Island, N. Y., the average of estimates at the east end are seventy-five and at the west end one hundred and fifty dollars.

Market gardeners living five miles out of Philadelphia, on tracts of twenty and thirty acres, devoting all their land and energies to growing 
vegetables, sometimes paying forty dollars per acre for rent, estimate that the necessary capital averages from two hundred to three hundred dollars per acre, according to the amount of truck grown under glass. These same men calculate the profits to be from one hundred and fifty dollars to two hundred and fifty dollars per acre.

370. Q. How long has the cabbage been in cultivation?

Cabbage.

A. The cabbage plant in a cultivated form was known two thousand years ago, and at the time of Pliny six varieties were in cultivation. The forms of the Brassica family are varied, some varieties being cultivated for their leaves, as the cabbage, where the terminal leaf-bud alone is active; others for their inflorescence, as the cauliflower, where the terminal leafbud is checked; others for oil, as rape, where the terminal and lateral leaf-buds are active; others for their enlarged roots, as the turnip, where the leaf-buds are the same as in rape.

371. Q. What is the most profitable branch of market gardening?

A. In the North the most profitable vegetable growing nowadays is done under glass, both in hotbeds, hothouses and coldhouses-profitable because the producers are limited in number, and as the products are sent to market at seasons when the markets are not glutted-out-of-season vegetables they may be styled. The most successful of such men have standing contracts with the best hotels, clubs and restaurants.

372. Q. Has there been much progress in methods of vegetable culture? Fegetable

A. Vegetable culture at the present day is quite aistinct from that of the past, for while gardening has been from ancient times termed an art, it may now, in its advanced condition, be termed an art supported, explained and dignified by nearly every science, all being called upon to account for the natural phenomena of plant germination, vegetation and maturity.

373. Q. Are all plants vegetables in a general sense?

A. The term Vegetable is very indefinite; for instance, the oak tree Definition of equally with the tomato is classed as a vegetable, the cucumber equally with the orchid, the seaweed equally with the mushroom; consequently, in a general sense, trees and seaweed are vegetables as well as cabbages or watermelons, those which are edible being termed esculent vegetables. There is a more critical division of those which are used as food and which may be said to pass through the kitchen for some preparatory preparation, culinary vegetables being the term used to denote this class. This classification omits from the class of culinary vegetables those products (as apples, grapes, pears) which can be used without cooking or without preparation of any sort, but this in fact is not yet correct, for the line of separation is best determined by physical characteristics.

374. Q. What is a culinary vegetable?

A. The private gardener, the market gardener, the commission mer-Vegetables. chant, all class as vegetables the potato and the tomato, the cabbage and the pea, the beet and the egg plant, the celery and the corn, the lettuce and the bean. This for all practical purposes is right, but physiologically 
is all wrong. Why? Because the egg plant, the tomato, the bean, the corn, are fruits. How many persons have ever taken the trouble to think over the difference between a culinary vegetable and a culinary fruit? What is that difference? It is a difference of origin of development. A culinary vegetable is properly the result of abnormal development of vegetable tissue, as in the enlarged leaves of the cabbage or the thick roots of the beet or carrot, while a culinary fruit, as also all fruit, is a growth following and resulting from inflorescence, as after the flower comes upon the same stem the egg plant, pepper, tomato, cucumber, watermelon, pumpkin. All these are fruits just as much as the apple, pear or grape. Some people might say fruits only grow on hard-wooded plants, as on trees and bushes, but not so, as a pea is a fruit, an ear of corn is a fruit. Nevertheless, these distinctions do not make them any easier or harder to produce, do not make them more or less profitable.

What is

375. Q. What is agriculture?

Agriculture? A. Agriculture refers to the tillage of the earth over broad fields, as for the raising of cereals, grass or tubers. Gardening, on the other hand, refers to the culture of small inclosed areas. This application of the latter term was quite correct originally, but it is now common for mere vegetable gardens to equal the area of ordinary grain and grass farms, requiring in their cultivation a degree of general intelligence, technical skill, and an amount of activity, implements and labor exceeding that expended upon large farms.

What is $370^{\circ}$ Q. What is gardening?

Gardening? A. Gardening again differs from farming in the range of rarieties cultivated. The farmer may devote his acres to those crops to which the land is adapted, but the gardener is expected to grow the entire list of vegetables, without reference to the composition of the soil. Such cultivation, to be successful, must be to some extent scientific. The cultivator must possess a knowledge of the facts and principles which underlie his art or he will certainly fail. Gardening, which formerly was described as agriculture upon circumscribed areas, has ever shared with the latter the esteem of mankind. Twenty-four hundred years ago Socrates said, "It is the source of health, strength, plenty, riches and honest pleasure ;" and a poetic English writer said, "It is amid its scenes and pursuits that life flows pure, the heart more calmly beats."

Market

377. Q. How does market gardening differ from private family gar. Gardening. dening?

A. It is done on a larger scale. Market gardening on a large scale may be termed commercial gardening, as the operator must, to a certain extent, be a merchant, fully alive to the import of fluctuating prices and quick to change his point of shipment or his consignee.

Market 378. Q. Is market gardening overdone?

Gardening. A. With the seven millions of people of Philadelphia, New York, Boston, St. Louis and Chicago, and the many millions more in other cities and towns which look to these great distributing markets for supplies, 
there is at seasonable periods little fear of gorging the markets if the fruit and vegetables be well chosen and well packed. Observe the use of the expression "seasonable periods," as of course no Southern grower of tomatoes, cucumbers, egg plant, or other garden products would expect to find a market for his goods in Northern cities when those markets were in receipt of the same class of garden truck from territory adjacent, the products of which would be fresher and cheaper than those from distant points. The shipper of fruits and vegetables from the South, attempting to cope with the garden States of New Jersey and Delaware, when their products are being sent to market, would only have his trouble for lis pay.

379. Q. What is the advantage of cropping cow peas?

A. To improve the fertility of the soil by the concentration near the surface of potash and nitrogen, seized upon and brought to the surface by the roots vertically descending to depths below and by the accumulation of nitrogen drawn from the air and held by the root galls-a notable peculiarity of this crop. The cow pea, which is properly a bean, will grow upon the poorest soils, and if the crop be repeated for two or three years will fit them in au astonishing degree for ordinary farm crops.

380. Q. How many families of cow pea are there?

A. There are two marked divisions; first, the Crowder, in which the Varieties. seeds are packed so closely in the pods as to be flattened on the sides; second, the Kidney formed. These two classes are divided into forty or fifty sub-varieties of various colors, habits, and periods of maturity. To produce a dense mass of vine to cover the ground and decay or to be plowed under green the best are the Calico, Black, Red Ripper and Clay. If to produce a big yield of dry seed, the best is the Unknown and the Clay. To produce a crop for ensilage the best are the Clay and the Whip-poor-will. For all-around purposes the Clay is as good as any.

381. Q. Is it advantageous to manure land intended for a crop of cow cow Peas. peas?

A. The primary object of growing cow peas is to add fertility to a poor soil. Now if the soil is very poor but a small crop of cow peas can be expected and consequently a small return of fertilization to the soil. It is therefore advantageous to force them by manure if the soil be exces. sively poor. The manure most effective in the forcing of cow peas is superphosphate of lime.

382. Q. In what way does clover, cow peas, and plants of the bean Legume family improve the fertility of soil?

Family.

A. On the roots of the legume family are developed certain organisms which acquire and hold nitrogen faster than other portions of these plants ; these are root galls or tubercles, the product of microbes or bac. teria. These root galls vary in number in different locations, but on plants of legume family are always present to a greater or lesser extent. As they have the faculty of absorbing nitrogen from the air, those plants which produce the greatest number of these galls are recognized as nat- 
ural, highly nitrogenous fertilizers. It is theorized that the number of these galls can be increased by treating the soil with microbe water. If this be correct a new system of intense and cheap soil fertilization will be developed.

Washed

Lands.

Inoculation

of

Soils.

American

Locust.

Insects.

Pea Bug.

Squash Borer.

333. Q. What is the best course in the recovery of washed soils or eroded lands ?

A. The first thing to do is to incorporate organic matter to the fullest extent possible. A soil charged with humus has the ability to absorb water and hold it till it percolates to depths below instead of running away. The second thing to do is to plow and cultivate the land so as to avert the rapid surface flow of rain water; this can be done by terracing and by side-hill ditches and contour cultivation.

384. Q. What is meant by the inoculation of soils?

A. It is a theory that a soil is rendered more fertile for a specific crop by transferring to it a top-dressing of soil from a field on which the previous year had been grown a crop of the new crop contemplated. For instance, if it is intended to put a field down in clover, it is theorized that the plants will be more vigorous and the crop altogether larger if the field be top-dressed or manured with soil from a field which was in clover the previous year.

385. Q. What kind of an insect is the American locust?

A. It may be described as a large grasshopper, coinmon throughout the Southern States and sometimes occurring in New York and New Jersey. It hibernates as an adult and lays eggs in MIay and June, the young in. sects appearing in July and August. It manifests a decided preference for corn, but feeds ravenously on oats, clover, potatoes and foliage of fruit trees. It seems to prefer elevated food, as watermelons, cucumbers and other low-growing plants often escape.

386. Q. How can insect depredations best be kept in check on the farm?

$\Lambda$. By Autumn plowing, which exposes the soil to the killing effects of frost. By rotation of crops and thorough cultivation.

337. Q. How does the pea bug get into the pea?

A. The flying mother insect deposits her eggs upon the outside of the pods when the pods are less than half grown. The eggs, under the heat of sun, hatch, and the young grubs eat their way sometimes directly into the young peas; at other times they mine along the inside of the pod, remaining there for days before they enter the pea. These weevil are propelled by false or temporary legs which they drop with their false skin when they enter the pea, not till it is nearly fully formed. After that they assume the ordinary form of larva of the weevil and remain till Autumn, when they eat their way out.

388. Q. My Boston Marrow and II ubbard squash last August were destroyed by the squash borer; what shall I do this year to protect my vines?

A. Kill the adult red-legged insects, which can be done about sunrise 
and sunset, as they can then be found sitting quite torpidly on top of the leaves.

389. Q. Are there plants which eat insects?

Carnivorous

A. Yes. Not exactly as animals eat their food, but certain plants are Plants. possessed of an irritability which gives power of seizing upon such insects as come within reach of the flowers, which possess digestive powers which chemically and functionally are somewhat parallel to the powers possessed by animals.

390. Q. Is there in any of the States a quarantine against insects, the Insect same as the European nations raised against certain American insects, as Quarantine. the potato bug, for example?

A. Only in California ; but there ought to be in every State, for we are not only disseminating all the insects of our American climates, but im. porting and distributing among ourselves all the insects and fungous dis. eases of the world.

391. Q. Do growing crops alone diminish the nitrogen of the soil to Nitrogen. the extent of their nitrogenous composition ?

A. No. Nitrogen disappears more rapidly than the crops alone remove it. It leaches away by drainage, and as the humus of the soil diminishes so does the nitrogen. It increases in a marked degree when the land is put down in clover or piants of that class. The principal loss of nitrates takes place in Autumn, and this can be partially provided against by the Summer and Autumn cultivation of nitrate crops, as clover, Southern cow peas, mustard, rape-green manures for plowing under after frost.

392. Q. What shall I do to make my truck farm pay a better profit?

A. Stop the cultivation of crops not clearly profitable. Cease making experiments on a large scale. Reduce the wages expended. Use the best labor-saving machinery and plant only the best seeds-and they are Landreths'.

393. Q. Why do garden seeds kept throughout the Summer months in Loss of the cotton States so generally lose their vitality?

A. Because they are subjected to an amount of moisture in the air which causes the germs to partly start into growth, weakening them for future effort.

394. Q. Last year I got from you ten pounds Boss watermelon seed and Irregular planted about half of it, the crop resulting being phenomenally fine re.Germination. specting quantity, size and quality. This year I planted the remaining half on adjoining field and it is just as inferior as it was last year superior. How is this?

A. It is all due to surrounding circumstances, as respects soil, rainfall, temperature, time of planting, kind of fertilizer and the influence of the previous crop. Every practical gardener has had this same experience.

395. Q. In what way do crops feed upon the organic compounds applied Plant Food. to or native to the soil?

A. They do not feed upon them as they are, but only after they have been reduced to their more simple component parts. These transforma- 
tions are largely effected by inferior organisms which inhabit all soils. There is accordingly much study applied to soil microbes, cryptogamic plants, many of which have power to an unusual degree of seizing upon and fixing the nitrogen of the air as well as that in the soil.

Drought.

396. Q. Why do some crops resist drought better than others?

A. Because of difference in length in the descending roots. Wheat, for instance, resists drought better than grass because it roots deeper. All plants root more deeply than generally believed, for they have vertically descending filaments which escape the notice of the ordinary observer.

Paris Green. 397. Q. How can I prevent Paris green from burning the foliage of plants ?

A. A chemical change can be brought about which reduces the burning quality by adding one pound of lime to every twenty gallons of the Paris green solution.

Crops on Sand.

398. Q. Can crops be grown on perfectly pure sand by the aid of artificial manures?

A. Yes ; Prof. Ville, of France, demonstrated that on washed sands he could grow good crops by adding to it component parts of plant foods, the product varying according to the component parts applied, as potash, lime, nitrogen, or phosphoric acid. These singly, or in twos, or in threes, or altogether; 3-inch culture, however, would not be profitable.

Bean Rust. 399. Q. Can the bcan rust be prevented?

A. It can be reduced by soaking the seed for one hour before planting in some of the copper baths, as copper carbonate or copper sulphate.

Cauliflower

Soil.

400. Q. What is the best soil for cauliflower?

A. The soil is not so important a matter as the subsoil and the atmosphere. Cauliflower to be of first quality should be grown quickly, and a quick growth is advanced by a copious supply of water which the roots can draw upon; consequently the plants do best where water occurs at a short depth beneath the surface. As to the location, the plant does best in a salt atmosphere.

Color in Plants.

Weevil in Beans.

401. Q. Is not the variability in the color, form, odor and secretions of flowers a provision of Nature to please the eye of man ?

A. It appears not to be that alone, but to be essential to the plants' existence, as all these qualities referred to aid in the work of insect pollination and result from insect pollination.

402. Q. How can I kill weevil in my beans?

A. If you can put them into a large glass bottle or a tin-lined chest or in a tin-lined chamber or room, you can then subject them to the fumes of bisulphide of carbon, deadly to animal life. One quart of the liquid allowed to volatilize, which it does quickly, is enough to kill the bugs in fifty bushels of secd exposed twenty-four hours to its influence.

Pea Bug.

403. Q. Will seed peas which have been cut by the pea bug germinate as freely and produce as well as peas which have not been effected by the bug?

A. Take one hundred peas and it will be observed they have not all 
been entered exactly at the same place; in some the germ has been destroyed-they certainly will not sprout; in some the interior is more eaten out than in others-they afford less food support to the young plant, which may never be healthy; others of the one hundred are uninjured as a seed stock.

404. Q. What is the remedy for destroying insects in small seeds-the Bisulphide. weevil in dried beans and the bugs in dried peas?

A. Subject the seeds in a closed vessel, as a pot, chest, or tight room, to the fumes of some deadly chemical preparation, as cyanide of potassium or carbon bisulphide. Don't inhale it yourself.

405. Q. What is the difference between a True Top onion set and the Top Onion. Egyptian or Winter Top onion set?

A. The True Top onion set is the product of the True Top large onion, which is planted out in the Spring to produce sets on top of the stalks (they do not produce black seed). The sets are planted to produce large onions. The Egyptian or Winter Top onion set is nothing more nor less than the original True Top onion, which has been allowed to remain in the ground year after year and has degenerated into a half wild condition; the sets will not produce a large onion, but grow in bunches in the form of scullions. Until they were introduced as a novelty they were regarded as utterly worthless. The two may be detected by cutting the set of each in half-the True type will cut to one eye and the Egyptian will cut to several eyes or hearts.

406. Q. Is it possible to bring the Egyptian or Winter onion back to its Winter original form-that is to say, a True Top set, which will produce a large, Onion. perfect onion? If so, what is the procedure?

A. It is not worth the effort. Better get the true stock at once, even if at double prices.

407. Q. Will seed beans which have been cut by the weevil germinate ? weevil.

A. A proportion will; but no one till after trial can tell what that in Beans. proportion will be. The weevil in beans is more severe than the pea bug in peas, as the bean weevil is more ravenous, eating a larger proportion of the interior of the bean, and frequently where one insect is present in a bean there are several, which in time will completely honeycomb the bean. Weevily beans should at once be burned np.

408. Q. What causes my radishes to be so scabby and eaten?

Radish.

A. Worms and grubs. No help for the present crop. Next year dress the field with lime and salt and avoid stable manure; use commercial fertilizers broadcasted early in the season. Use kainit.

409. Q. Can I grow chicory as a substitute for coffee?

A. Yes; a very good substitute. It is grown exactly like carrots or parsnips: it should be taken up in October and sliced and dried. The Landreths cultivated it during the war, in the sixties, and sold the roots to coffee men.

410. Q. Does not self.blanching celery, both white and golden, show a Celery, tendency to produce green plants? 
A. Yes, to revert to the original form; and it is well it does so, other. wise they both would become so dwarfed and puny as to soon go out of use.

Cutshort Beans.

Broccoti.

Rhubarb.

Drought.

Turnips.

Celery, Self-blanching.

Firming the Soll.

Heau Rust.
411. Q. What does the word "cutshort" signify, as applied to cornfield beans?

A. Cutshort and snapshort both signify the same thing; that is, a bean producing a green, edible pod, without a string, but they are not always stringless.

412. Q. What is the difference between broccoli and cauliflower?

A. Broccoli, though quite similar to cauliflower, is a plant taking longer to mature. It does not make so dense a head as cauliflower and the head is often divided in sections by leaves protruding through it. Broccoli, as a rile, is cultivated in a more southern climate than cauliflower.

413. Q. Can a fixed variety of rhubarb be obtained from seed ?

A. Not absolutely; but great improvements have been accomplished in the last few years. A positively fixed type can only be had from cuttings from roots from an approved type.

414. Q. That effect has drought upon root crops, such as beet, carrot and parsnip?

A. It reduces the product and results in a crop of dry, tough, inferior roots and a stock more likely to decay than if it had been grown under healthy conditions. Drought sometimes causes them to shoot to seed the first season.

415. Q. With a few exceptions, all my neighbors who planted Lan. dreths' turnip seed failed to obtain good bulbs, only strings; but I got a crop. How is that?

A. Unfavorable circumstances as respects soil and other conditions. If one man succeeded and others did not, the trouble was not with the seed but was local; anyone should clearly see that.

416. Q. Is self-blanching celery tender and crisp, or must it be earthed up like other celery?

A. The term "self-blanching" only indicates that the plants have a habit of developing stocks and leaves from which a portion of the usual green color has been eliminated by selection. The blanching habit does not indicate a crisping habit ; that is only obtained by exclusion from the sun, banking in earth or between boards.

417. Q. I noticed the other day an old trucker running a wheelbarrow over his beet seed which he had just finished drilling. What was the object?

A. To "firm" the soil; that is, to compress the seed and soil that they might be brought into contact to hasten germination and facilitate vegetation.

418. Q. My beans this year have all spotted. Can I do anything another year to prevent the recurrence of this effect ?

A. You call adopt a preventive. Bathe the seed beans before sowing in a copper solution, but don't spray the vines when they are bearing 
marketable pods with such a solution, as the pods might carry the poison.

419. Q. How is it seed sown in the drill very often comes up in spots ? vitality. Does it indicate unvital seed?

A. The question almost answers itself, for, if the seed sown sprouted thickly in several places or even in one place, it demonstrates that had the conditions been good there would be an equal germination all over the field; that the seed was all right-something else was wrong.

420. Q. How is it that double varieties of flowers can't be produced Donblo from seed with the same reliability as single sorts?

Flowers.

A. Double flowers are abnormal, that is, out of the ordinary form. The sexual organs often becoming entirely changed in development, often indeed becoming leaves themselves.

421. Q. Can I apply Paris green to my small cabbages?

Paris Green.

A. Yes, when they are very small, as subsequent rains will wash out from the joints any of the mineral poison which may lodge there; but when the plants are heading it would be criminal to apply Paris green.

422. Q. What is the cause of smut on onion sets and how can it be pre- Onion Smut. vented?

A. It is a fungous growth which may be partially prevented by bathing the seed in a copper solution and by spraying the plants with the same. A soil.dressing of salt has a good effect. It can be had in kainit, which also contains potash.

423. Q. Can crops be bred to ripen earlier by selecting seed stock from Unripe Seed. plants not thoroughly ripe?

A. Yes, a very noticeable result can be obtained after three or four years of diligent application. By that time the stock is truly a pedigree stock and will develop a character of marked earliness compared with the stock from which it was originally derived.

424. Q. What is your experience with Winter or turf oats?

Winter Oats.

A. On our Virginia plantations we have cultivated it for thirty years with great satisfaction. It produces a greater number of pounds to the acre of heavier seed than we can obtain from any other sort. We sow it in September and it gets a foot high by December. It can be pastured all Winter but not after starting in the Spring.

425. Q. How is it that to obtain a continued bloom from sweet peas the Sweet Peas flower should be regularly cut off?

A. Simply because sweet peas are like everything else : if allowed to develop seed the drain upon the vitality of the plant absorbs all its vigor and flowering almost ceases. It is the same with cucumbers. Cut off the young, green pickles, and there will be continuous blooming ; but permit the first settings to form large fruit and the blossoms will cease to appear.

426. Q. Can sweet peas be successfully grown in the Southern States? Sweet Peas

A. Certainly; but the seed must be sown in November, December or in South. January, that the vines be developed in the early Spring months.

427. Q. Is it possible to keep watermelons till January and retain their Mrelons. flavor? 
A. Melons of late development picked before they are ripe, can, in an ice house, be kept till January, with the flavor still attached to them. But a man's desire for watermelon is not so keen when the thermometer is below the freezing point as when it is up in the nineties. Consequently he turns from it with the remark that it hasn't any flavor.

Radish. 428. Q. I have a patch of radish grown from a remnant of your seed left over from last year; then the crop was fine, but this year the plants shot up to seed without making bulbs.

A. This will sometimes happen, and is a consequence of local conditions. Each case has its own explanation. Such results are unprofitable to market gardeners, but they never give us any concern, for we cannot control soil treatment or meteorological conditions.

Egg Plant, 429. Q. Down here in Florida I have to sow my egg plant seed in Sowing Seed. August. What is the best system?

A. The worst system is to plant the seed in a permanent location out in the open sunlight. If that must be done, shade the planting spots with palmetto leaves. The better system is to sow the seed in cold frames, where they can be watered with manure liquid and removed to the field on a rainy day. Still better to spot the seed in strawberry boxes or pieces of tough turf and nurse them in the shade till three inches high. Set out in this way and they won't know they were moved.

English

Beans.

Harlequin

IBug.

Nomenclature.

Agriculture.

430. Q. In England, as a boy, I was almost brought up on broad beans. Why are they not used here?

A. Very few people in America use English broad beans, as the cut. short or snap-short varieties are superior. Americans have no room for them; in fact, they won't stand an American sun.

431. Q. We are troubled in our cabbage fields this year with the greenand-yellow bug, somewhat like the large ladybug, but bigger-better described as like a terrapin. What can we do to destroy it ?

A. It is the harlequin bug, one of the worst of all insect pests. It is a juice sucker and cannot be destroyed by mineral poisons applied to the foliage, as it does not eat foliage but pierces the stem and extracts the sap. It can only be destroyed by hand picking and by suffocating it by clog. ging up its breathing apparatus.

432. Q. Why is it that there is so much confusion in the names of vegetables?

A. The irregularities of nomenclature can never be regulated by law or by the resolutions of horticultural associations, for dealers in seeds prefer to add to the confusion rather than lessen it. New names to old things give opportunities for new descriptions and higher prices.

433. Q. Is agriculture a failure; that is, is it unprofitable?

A. That depends on what constitutes success. If success alone means a big fortune and prominence in city life, then agriculture is indeed a failure; but if it means a healthy bodily constitution, a fair accumulation of worldly effects, and a spirit more contented than possessed by men in other pursuits, then agriculture is a success. 
A. It is a bulb prematurely matured, a consequence primarily of pecu- Onion Set? liar climatic conditions, and secondarily a result of thick seeding and consequently starvation. It is not a perfectly matured bulb, else, however small, it would produce seed the following year. On the other hand, it is not a bulb arrested in its growth by violence, as by pulling up and wring. ing off the green top, as is generally the case in the treatment of Western onion sets, often sold at what appear to be cheap prices, but really very dear prices. The leaves of a true onion set always die down perfectly. The climate of Philadelphia for one hundred years has been recognized as particularly adapted to the growth of onion sets; indeed, there, nothing but sets can be grown, for try ever so hard and frequently to produce onions from seed, they seldom or never can be developed. Every plant makes a set; the climate forces them to it. The writer does not believe good-keeping sets, or first-class sets in any particular, can be grown in any locality where full-sized market onions can be grown, the conditions required for the one crop being antagonistic to the other.

435. Q. Does the color of beet leaves indicate the color of their roots? Beet Leaves,

A. Not always. Some beets, as the Dark Red Turnip forms, have dark Color. red foliage, but the Long Blood Red, having a flesh fully as deeply colored as any other, has leaves of varied colors, soine red and some green, the flesh of the green-leaved roots being fully as red as the red-leaved roots.

436. Q. What does the word "Savoy" signify, as applied to spinach Savoy. and cabbage?

A. The expression "Savoy" was first attached to cabbage when a small, crumpled-leaved variety was introduced from the kingdom of Savoy, Italy. Subsequently David Landreth found a spinach with crumpled leaves which he called "Savoy spinach," because it was crumpled like the leaves of the Savoy cabbage.

437. Q. What does the word "Cos" signify as applied to lettuce? Cos.

A. It is applied to a sort which originated, or at least was found, on the Island of Cos, near Malta, in the Mediterranean sea.

438. Q. What is the effect of nitrate of soda on garden vegetables? Nitrate of Can it be used to the exclusion of other fertilizers?

Soda.

A. Nitrate of soda is valuable for its nitrogen, one of the four principal essentials to plant growth, which are nitrogen, phosploric acid, potash and lime. This being the case, nitrate of soda, it will be perceived, is not a complete food and should not be depended upon exclusively. Nitrogen can be had in many other forms.

439. Q. Why do cabbage plants so often act differently as respects the Cabbage. production of heads when the treatment has been just the same?

A. Variability as respects heading, as evinced by a want of uniformity of heading or period of heading, is all due to conditions, many of them beyond our observation. Ofttimes an injury is received by plants in the seedbed, or it may be frost, or excessive drought, or it may be the condition of the land into which the cabbage was transplanted. 
Plant

Degeneracy.
440. Q. Do plants run out or degenerate?

A. Families seldom run out, but varieties frequently do. For instance, the potato as a family was never equally developed in all good qualities, as at present, but there have been hundreds of instances of particular sorts of superlative merit which are now forgotten varieties which degenerated and passed out of use. Such degeneracy applies more particularly to those specific sorts of plants as are propagated by grafts, buds or tubers, as in those cases the collective diseases of more or less remote parents, scions or buds are often passed down through a long line of progeny. Not so with other plants produced from true seed, as either through the male or female flower the blood by impregnation is changed and the product generally strengthened physically.

Cheat.

441. Q. Does wheat turn to cheat?

A. No. Seed of cheat, a hardy grass, botanically known as Bromus sicalinus, is often sold in imperfectly cleaned seed wheat, and being more hardy than wheat survives wheat in severe Winters. The ignorant farmer then jumps to the idea that his wheat has turned to cheat.

Transplant- 442. Q. Why are root crops intended for seed nearly always transing. planted?

A. To induce a degree of debility of constitution-to check the luxuriance of growth, all of which induces a disposition to shoot to seed and helps to maintain a standard quality.

Fences. 443. Q. What is the cost of supporting the fences in the State of Pennsylvania?

A. The official report places the annual repairs at about ten millions of dollars.

Cloche. 444. Q. What is a cloche?

A. A large bell glass about sixteen inches high and broad, used in France to force vegetables. A gardener with 100 of these can surpass all his neighbors in forcing early vegetables. Particularly valuable in the forcing of salads, radish, and in the protection of vines from cucumber bugs.

Insects or 445. Q. Which is most to be dreaded by the gardener-destructive inFungi. sects or fungi?

A. Fungi most decidedly, as it works so insidiously. Insects can be seen and partially understood, picked off, frightened off, killed off ; but parasitic fungi may be present for weeks without it being recognized. There are many forms of fungi feeding upon the leaves and roots of garden vegetables, most of them fortunately too trivial to deserve notice.

Clover or l'eas. ing under as a green manure, and has one or either any advantage over Southern cow pea?

A. No advantage, except that the Scarlet clover is very rapid in development, attaining in a season, from August to June, as much development as Red clover would arrive at in twice the time. Cow peas sown in July can be plowed under in September and October, and are very good fertil- 
izers, being potash gatherers from the soil below and nitrogen gatherers from the air above.

447. Q. How late can Crimson clover be successfully sown in the lati-Scarlet tude of Savannah?

Clover.

A. Sown as late as November 1st, it should attain a sufficient vigor of growth to make a big crop in the Spring ; sown later, it will of course flourish, but a big crop of hay to cut or green stuff to plow under cannot be looked for unless the plant had a good start in Autumn. No striking fertilizing results can be expected from a plowed-under crop of Scarlet clover where the sowing of seed has been late and where the plowing under is early, as its merit consists in the collection of potash from the soil by the roots and of nitrogen by the leaves and roots for storage in the root galls, and all this cannot be done to any great extent between November and April. Sown in August the results are better.

448. Q. Is there a marked difference in the habit of tomatoes grown Tomatoes. upon light and heavy soils?

A. Grown on light soils the vines are puny, the foliage small and sparse, the fruit small but very early, and because of thin foliage liable to sunburn. On heavy soil the conditions are just the contrary.

449. Q. What is your experience in the use of Lobos guano?

A. It is that it is not worth quarter the money asked for it. No reliance can be placed upon it for the making of a crop. Put your money in some other fertilizer.

450. Q. My cabbage plants in beds, now ready for setting in the field, Cabbage are ruined by black stem, the bark of the stem sluffing off. What is the Fungus. trouble and what the remedy?

A. The disease is a parasitic fungous growth. There is no remedy that would justify the assumption of subsequent expenses on your cabbage crop. Better pull up and burn the entire lot of plants and purchase healthy plants from an unaffected bed.

451. Q. What is leaf blight?

A. It is a decay consequent upon arrested nutrition following insect or fungous attack. Leaf blight as an expression does not indicate the nature of disease, for the blight may follow ravage by either insects or fungus. Leaf blight on garden vegetables is generally the outward sign of a parasitic fungus known also as rust, mold, smut, mildew. It is difficult to describe the almost inconceivable smallness of the most destructive garden fungi.

452. Q. How is a resin wash made?

Resin Wash.

A. Take three pounds pulverized resin, one pound pulverized caustic soda, one gallon fish oil, and, with sufficient water, boil till dissolved and an hour longer. Add twenty gallons of water, strain and spray. This is a good insecticide for sap suckers, acting by contact.

453. Q. Name a good preventive against the cutworm in corn.

A. Kainit, a potash salt which destroys the worm while at same time stimulating the plant to vigorous growth. 
Grubs. 454. Q. What is the best application to check the ravages of under. ground grubs ?

A. Kerosene emulsion has been found beneficial upon root-crops of

Arsenical Poisons.

Grastes

for

dry soils.

Fungi and Insects.

Plant

Diseases.

Pea Mold.

Rye Grasses.

Half-ripe seed.

Vegetable Diseases. radish, and will be found offensive to all grubs.

455. Q. What are arsenical food poisons?

A. Paris green, arsenite of copper, white arsenic, arsenious oxide, London purple, calcium arsenite.

456. Q. What kinds of grass are best adapted for culture in arid districts?

A. Those with deeply-penetrating roots and others with thickened or fleshy, creeping, underground stems. Gramma, Buffalo, Bermuda, and Wire grass are the best. Shallow-rooted, broad-leaved grasses won't do.

457. Q. Do insects dwelling upon garden vegetables eat fungi growing upon the same plants?

A. Yes; very generally; and a portion not eaten are taken up by the hairs of insects and thus carried from the infected plants to healthy ones. Some garden fungi germinate and continue to grow upon the bodies of insects.

\section{Q. Is disease hereditary in plants?}

A. By analogy it is so, and it is believed observations have proven it. It is impossible to overestimate the importance of caution in the selection of healthy seed.

459. Q. What causes pea mold?

A. There are several forms of pea mold. One developed principally under conditions of damp, close atmosphere and retarded by dry weather. Another form is favored by dry atmosphere and retarded by rain. Nothing can be offered as a satisfactory remedy to destroy the fungus whilc preserving at the same time the value of the crop.

460. Q. How can I distinguish Perennial Rye grass from the Italian?

A. The bases of the Perennial are red and flat. The bases of the Italian are red and perfectly round.

461. Q. Can a variety of a garden vegetable be made earlier by growing it from half-ripened seed ?

A. Experiments have demonstrated this to be so, provided the system be continued for three or four successive generations. Plants grown from such pedigree seed show an early habit because they are weak and puny. Continued long enough the resultant crops would become exceedingly unproductive.

462. Q. Are diseases of vegetables increasing?

A. No; not to any great extent. But the close intercourse of remote sections of the country tends to introduce into every section the fungous diseases of every other section, and under the conditions of greatly increased scientific agricultural knowledge the public has its attention called to what some years ago would have passed unnoticed. Then as now nearly every esculent vegetable was subject to disease, in fact it is rare that any garden vegetable can be found not supporting a foreign 
growth. In the Bloomsdale experimental garden every plant of every family may be said to be affected either in leaf, stem or root, and the plants there grown are healthy as can be found anywhere. Smut or mildew or sume other form of disease may be said to be always present.

463. Q. The United States Secretary of Agriculture declares that the The Plow. plow is a humbug. Is he correct?

A. After he invents a better implement he will be a better authority. Political commissioners do not make practical farmers.

464. Q. What is the potato vine blight?

A. The potato is subject to the attacks of several parasitic fungi, two or more of which attack clover and lettuce, appearing as patches of white film, which, in a few weeks, spread over the entire plant, extract the juice and reduce the vigor of the plant so that growth of tubers ceases. There is no remedy for this disease, and to prevent its spread exceedingly great caution has to be observed in burning all the stems of the infected crop.

465. Q. Where does the white grub come from?

A. The white grub is the larvie of the familiar June bug, or, more correctly, May beetle, which, in the early Spring months, enters dwellings in the evening, swarming about the lights, buzzing loudly and violently, knocking themselves against the walls and ceilings. The perfect insect feeds upon the foliage of trees, and is more or less destructive. The eggs are deposited in the earth, and hatch in about a month. The grubs remain in the ground, doing little injury till the second Summer, when they attack the roots of plants. They remain as grubs in the earth for nearly three years, by which time they reach a length of two inches, and often appear in such great numbers as to do immense damage.

466. Q. My asparagus, now about ready to send to market, is being destroyed by the beetle. What can I do?

Asparagus Beetle.

A. Nothing can be done to destroy the asparagus beetle upon the marketable shoots, as mineral poisons would be destructive to human life, and offensive applications would destroy the value of the crop.

Asparagus beds past the marketable condition of growth can be dressed advantageously with a solution of a tablespoonful of Paris green in four gallons of water, which will be generally found to kill the slugs. Sometimes effective results ensue by the application of freshly slaked lime while the dew is on them, for the least particle of lime touching the skin of a slug is certain to kill it.

467. Q. Why do turnips, beets and carrots keep better some seasons Turnip than others?

Preservation.

A. Probably because better protected from frost-or possibly no amount of protection would have prevented decay, as the roots may have been sickly, consequent upon an unhealthy growth, the result of Autumn weather conditions, either too wet or too dry, or damage by insects or fungous growth. 
Green Manuring.

Exhaustive Crops.

\section{Bulbs.}

Starch.

Tubers.

Inlialation.

Exhalation.

Pollen.

Tollen.

Vitality.
468. Q. Can I consider a mass of hog weeds plowed under as a manur. ing of the land?

A. Yes; to a small extent; but not so efficient as if the plants plowed under were noted as collectors of potash from soil depths or of nitrogen from the air. The benefit from a mass of common surface weeds turned under is more from aerating the soil than from any direct fertilizing effect.

469. Q. Why do some crops seem to poison the land, unfitting it for others?

A. Crops all act differently upon the soil by taking from it different foods or different proportions of food ingredients. Consequently they leave the land in different conditions. Cabbage, for instance, is such a rank feeder that it takes everything it can reach. Spinach the same. Other crops seem to render the soil inert. Millet, for instance, is so slow to cover the land that the soil suffers by exposure to sun, wind and rain; it becomes baked and after the millet is cut off seems almost dead.

470. Q. What are bulbs?

A. Fleshy buds, generally underground, but sometimes formed on the surface. They might be termed abbreviated stems of plants.

471. Q. What is the reason that wheat and other grains are so valuable?

A. Because of the starch they contain in admixture with nitrogenous matter.

472. Q. Why is a potato called a tuber?

A. The natural formation of the potato has to be called something, and it might just as well be called a tuber as something else. The word is from a Latin root, to swell. It is an enlarged underground bud.

473. Q. Do plants breathe?

A. Certainly; though not exactly in the sense of animal respiration. Plants, however, take in air and decompose it, retaining certain portions and rejecting others.

474. Q. How much water do plants exhale?

A. Wheat, peas, beans, during their season of growth transpire quite two hundred times their dry weight of water. An acre of cabbage will transpire in a day over ten tons of water.

475. Q. To what distance can pollen be carried?

A. Cases are recorded where pollen has been wafted thirty miles.

476. Q. How long will pollen retain its vitality?

A. Sometimes for months-quite long enough to transport it from one country to another.

477. Q. What are the longest instances of retention of vitality in seeds?

A. Seeds of leguminous plants have been known to sprout after being kept for sixty years. Rye has been known to sprout after one hundred and forty years.

Germination. 478. Q. How can the germination of seeds be stimulated?

A. By soaking in weak chlorine water.

Sowing seeds 479. Q. Is it the best policy in sowing small seeds, as turnip, spinach, carrot and beet, to drill on the level or on ridges. 
A. On ridges; but not more than of one inch elevation when settled down. On ridges the seed just drilled is not subject to flooding by rain and throughout the season is more easily kept clean.

480. Q. When spraying plants how much solution should be applied? Spraying.

A. Just enough to thoroughly moisten the foliage of the plants.

481. Q. Can a fungus working beneath the surface of the soil be checked Fungus. by Bordeaux mixture?

A. Very doubtful.

482. Q. Can cabbage plants which have developed club root be made Club Root healthy by any application?

A. No. Once the fungus has taken hold of a cabbage plant no appli. Cabbage. cation will make that plant healthy. As in the case of turnips, a preventive is an application of sixty to seventy bushels to the acre of airslacked stone lime.

483. Q. What is the best remedy to use in the treatment of club root in club Root turnip?

A. There is no remedy to arrest the disease, but air-slacked stone lime Turnip. used at, the rate of seventy to eighty bushels to the acre, and applied before the sowing of the seed, retards if it does not destroy the fungus.

484. Q. How can I make Bordeaux mixture?

Bordeaux

A. Provide half sections of whisky or vinegar barrels in which to do Mixture. the mixing and contain the solution. Take as follows, or in greater pro. portions, five pounds sulphate of copper, five pounds quicklime, twentyfive gallons water. Dissolve the sulphate in two gallons of hot water, slack the lime in two gallons of water, and thoroughly strain it to remove all sediment, and when cold mix it with the solution of sulphate. Then mix the whole In the remaining twenty-one gallons of water.

485. Q. What is the name of the bean rust and how can it be prevented? Bean Rust.

A. The bean rust is a fungus known as anthracnose, and it attacks not only the pod but the foliage and stems. A partial preventive is, as soon as the young plants are above ground to spray them with Bordeaux mixture and repeat the application every week.

486. Q. What is the best spraying solution to stop leaf blight on potato spraying. vines?

A. Bordeaux mixture reduced to half strength by the addition of water. 487. Q. Do you advise a bath for potato seed before planting?

Potato Bath.

A. Yes; plunge the cuttings for two or three hours in a solution made in the proportion of ten ounces of corrosive sublimate to eight gallons of water. This deadly poison is a preventive of the fungus causing scab on young potato tubers.

488. Q. What should be done to drive off the squash bug?

A. As these bugs are sap suckers no application of mineral or other Squash Bug. poisons is effective. The only remedy is after the crop is over to destroy all vines and avoid planting on the infected ground.

489. Q. What is the best remedy against the striped cucumber beetle? Cucumber A. There is no best remedy. Spraying with arsenites applied from an Beetle. 
under-spray nozzle is sometimes effective, as they are consumers of leaf tissue, but they are insects hard to fight.

Larræ. $\quad 490$. Q. What are larvæ?

A. Worms or grubs hatched from the eggs of insects. The larvæ form is that in which insects do most damage to vegetation. After a time the larvæ assume the quiescent state, or pupa form, in which they exist during Winter, to appear in Spring in a fourth form, the perfect or imago form.

Squash Borer 491. Q. Is there a remedy against the squash vine borer?

A. None yet known. An effective plan is to kill the moths, which can be done after sunset, when they roost in full view upon the leaves.

Melon Lice. 492. Q. My melons are covered with lice. What shall I do?

A. Spray with one pound whale-oil soap dissolved in six gallons of water, or with fish-oil soap dissolved in eight gallons of water; or, still better, use kerosene emulsion. Bordeaux mixture or Paris green is of no value in this case, as these insects are of the sap-sucking order.

Kerosene 493. Q. How is kerosene emulsion made?

Emulsion. A. Take a half pound of common softsoap and one gallon of water, and, by agitation, make a complete sud. Mix this sud by violent churn. ing with two gallons of kerosene. It is a contact insecticide of great penetrative power and must be diluted by ten or twelve parts of water.

Kerosene 494. Q. Against what insects can I use kerosene emulsion ?

Emulsion. A. It is effective against all garden lice, rose slugs, leaf rollers, root maggots, hairy caterpillars and scale insects.

Use of

Paris Green. foliage?

495. Q. Can anything be done to prevent Paris green from burning

A. One pound of Paris green to one hundred gallons of water is a rather strong solution, but to one hundred and fifty gallons of water one pound of Paris green is safe. Safety can be assured by adding four gallons of limewater.

Destruction 496. Q. Can all garden insect pests be destroyed alike?

of

Insects.

A. No ; because there are two distinct orders of insects destructive to garden vegetables-the leaf eaters and the sap suckers. The first take leaf matter into their stomachs and can generally be poisoned by a variety of substances, as Paris green, London purple, etc. The second order can only be destroyed by bodily contact with some application which, if successfully applied, stops the breathing apparatus of the insects. This material may be preparations of oil, tobacco dust, pyrethrum, lime.

Plant Food 8. 497. Q. Can vegetables and farm crops be divided into classes, each requiring distinct food?

A. Partially so, and divided into three classes :

1. Those requiring an excess of potash, as peas, beans, potatoes, clover, flax.

2. Those requiring much nitrogen, as beets, cabbage, oats, wheat, barley and hemp.

3. Those requiring large amounts of phosphoric acid, as radish, turnip and corn. 
498. Q. What are the average commercial prices of fertilizers, taking Value, each separately?

A. The average prices of the leading four manurial substances are :

\begin{tabular}{|c|c|c|}
\hline Nitrate of potassa $\ldots \ldots \ldots \ldots \ldots \ldots \ldots \ldots 6 \frac{1}{2}$ & “ & “ \\
\hline Nitrate of soda................... $2 \frac{1}{2}$ & “ & “ \\
\hline Sulphate of ammonia............... $\frac{1}{2}$ & “ & “ \\
\hline Sulphate of lime................. $\frac{1}{2}$ & “ & “ \\
\hline
\end{tabular}

499. Q. Is nitrogen as necessary as writers make out?

A. Nitrogenized matter in the soil is absolutely necessary to the grow th Nitrogen. of vigorous crops; and the fact cannot be too strongly impressed on every gardener that nitrogen and phosphoric acid are the leading manurial ad. ditions required, and a cheap and eflicient method of application should occupy his constant attention.

500. Q. How do plants get nitrogen?

Source of

A. Nitrogen, in the form of atmospheric ammonia, is largely obtained Nitrogen. by plants through their leaves, but to an equally large extent does the soil get it by absorption, and, if covered, it holds it; and in this simple fact is one of the several secrets of green manuring, the entire benefit not being through plant absorption.

501. Q. Where can I get nitrogen?

Nitrogen

A. Assimilable nitrogen may be had, to the extent of twenty per cent., Supply. in sulphate of ammonia, fifteen per cent. in nitrate of soda, fourteen per cent. in nitrate of potassa, or it can be had in dried blood or flesh from slaughter houses or fish factories. The nitrates, preferably that of potassa, are best for vegetables, especially root crops ; the sulphates for the cereals.

502. Q. Where can I get potash?

Potash

A. Potash is contained in wood ashes, but is obtainable in larger quan-Supply. tities in nitrate of potassa, commonly known as saltpetre, which salt should contain forty-five per cent. potash, with the valuable addition of fourteen per cent. of nitrogen.

503. Q. Where can I get phosphate of lime?

A. Phosphate of lime can be had, to the extent of fifty per cent, in bone dust, seventy per cent. in bone ashes and bone black, and in superphosphate of lime, which is phosphate of lime treated with sulphuric acid, and which, when properly dome, should contain forty per cent. of soluble phosphate.

504. Q. How and where is lime found?

A. Lime is found chiefly in the carbonate of lime, as chalk or limestone, and in the sulphate of lime, as gypsum or plaster of Paris. The sulphate is best, as most soluble.

505. Q. Where do plants get their food?

A. Plants draw some food from the air by their leaves, but most from Lime. the earth by their roots. The composition of the air is quite constant, 
Cabbage Worm.

Kerosene Enulsion.

Cabbage

Louse.

Onion Fly.

Seed to Sow 100 Yards. but the character of the soil is exceedingly variable, and crops grown: continuously upon a soil draw out one or more of its nutritive principles; consequently, it can only be reinvigorated by returning to it those elements removed in the crops.

506. Q. What shall I apply to my cabbage to kill the green worm?

A. The cabbage worm is a green caterpillar, feeding on nearly all broad-leaved vegetables, especially cabbage, cauliflower and lettuce. It is the larvæ of a white butterfly of European origin. Paris green will poison these caterpillars, but, except in the very early stages of cabbage growth, it is unsafe to apply so poisonous an article to a plant which might enfold the poisonous compound within its leaves and kill those who afterwards ate the plant. Pyrethrum has been found effective.

507. Q. Are there several ways of preparing kerosene emulsion ?

A. Yes; several ways of arriving at the same end-as take : One part. sour milk, two parts kerosene, thoroughly mixed by rapid agitation till the combination forms a creamy liquid. To this add fourteen parts water, and apply by an injector, or dash over the vines with a broom. The emulsion may also be made with : One quart soft soap, one quart kerosene, two quarts water mixed by forcible agitation, and diluted with sixteen quarts of water. Apply to the plants forcibly with a syringe.

508. Q. Can I kill the cabbage louse?

A. The Downy cabbage louse is a mealy, soft-bodied insect, sometimes appearing in thousands, swarming. like bees upon the leaves of young. cabbage, Brussels sprouts and cauliflower. It can be checked off by the application of kerosene emulsion, but it is difficult to drive it off entirely. 509. Q. Can the ravage of the onion fly be stopped?

A. Equal parts of wood ashes and land plaster dusted very thoroughly on the young plants will generally drive them off. An application of some efficiency is, one part of Paris green, mixed with forty or fifty parts of land plaster or flour.

510. Q. Give me a rule to indicate how much seed to purchase for a garden, the length of the rows in such case being one hundred yards.

A. One ounce of cabbage, cauliflower, collards, broccoli, Brussels sprouts, egg-plant, kale, kohl-rabi, pepper. All these to be transplanted.

Two ounces of onion, leek, lettuce, endive, parsley, canteloupe, squash, pumpkin tomato, turnip.

Threc ounces of carrot, cress, celery, chervil, watermelon, parsnip. herbs.

Four ounces of cucumbers, nasturtium, rhubarb, salsify, scorzonera.

Five ounces of beet.

Six ounces of radish, spinach.

Eight ounces of corn salad.

Twelve ounces of okra, asparagus.

One pint of field corn.

One quart of sugar corn.

Three quarts of bush beans, peas. 
511. Q. What are the signs for planting garden?

Planting

A. In the Northern and Middle States the average season for open-air Signs or seeding may be indicated by the blooming of well-known trees and Periods. shrubs, though seeding may be made with pronit both before and after such periods, as it is a safe rule in gardening to divide the risks. For instance, when the peach is in bloom sow those seeds which will germinate in cold soil, resist slight frost, as peas, spinach, onion and leek. When the oak bursts its leaf buds sow beet, carrot, celery, lettuce, parsnip, radish, salsify, turnip, tomato. When the blackberry is in bloom sow those seeds which will thrive only in warmer soil, as the bean, corn, cucumber, canteloupe, watermelon, pumpkin, squash, okra.

512. Q. How much time must I give my seeds to sprout before deciding Germination, to break up the land and sow a second time?

A. The time required in germination greatly varies, dependent upon the species of plant, the age of the seed and the surrounding conditions of soil and atmosphere. Under favorable circumstances, peas, beans and corn should sprout in three days; cabbage, turnip and radish in four days; vine seeds, such as melon, squash and cucumber, in five or six days. Germination, however, does not guarantee vegetation, as seeds showing a germ may never appear above ground if physically weak, if too deeply covered, or if the soil is hardened by rain or heat.

513. Q. Which is the greater loss to the garden, unvital seed or impure Unvital or seed?

Impure Seed.

A. If seed prove unvital a new purchase can be made and a new planting follow within a few days; but impure seed is more deceptive, as its very vigor secures the crop attention and labor to be subsequently found wasted. Of the two evils, unvital seed or impure seed, the first, by all odds, is the least.

514. Q. Must I thin all my crops, or leave some just as they sprouted ? Thinning

A. Do not hesitate to thin out, no matter how sturdy and attractive the Crops. plants may be, for the plant which crowds another is simply a weed. This thinning should be done before the plants be drawn or elongated in their stems or leaves, or they will ever afterwards show the injurious effects of crowding. It may be done by cutting out with a hoe or knife those plants which are not needed elsewhere, or, if considered worth transplanting, they should be carefully dug up, that the finer roots be preserved. No vegetable or flower will properly develop if crowded; certainly one symmetrical plant is worth a dozen sickly ones, not only for market but in general satisfaction.

515. Q. Why do some seed merchants commit errors in filling orders Errors by for seed?

A. Because their employés are human. When seed buyers are ready Merchants. to pay better prices for seeds perhaps the merchants can afford to employ angels to put up the orders; angels may be infallible. "To err is human : to forgive, divine." 
Ruta Baga. 516. Q. Why don't I have better success with ruta baga in Georgia ?

A. Because you sow it in July-so early that the plants get necky, badly shaped and tough. In Virginia we have grown healthy, sweet ruta bagas sown as late as August 25th.

Canteloupes. 517. Q. After the first picking of our crop of canteloupes, which may be fair, we seldom get any others not injured by the worm. Is there a remedy?

A. No; no remedy that is satisfactory.

Bermuda

Grass.

518. Q. I have never been able to get seed of the Bermuda grass that will germinate, though I have bought it from the most reliable seedsmen. Please explain the cause of failure to germinate.

A. We have never had any seed that would germinate over ten per cent. It cannot be saved in a mature stage, as it drops as soon as ripe, and must therefore be cut green, hence the want of vitality. Setting out the roots is the only royal road to success with this grass.

Asparagus. 519. Q. Is there such a varicty as White asparagus? If so, is it any more desirable than the Green-top or Purple?

A. Yes : there is a variety, of fixed habit, producing white shoots. It has the appearance of having been bleached and, consequently, is quite salable.

Canteloupes. 520. Q. Are large canteloupes as sweet as small ones?

A. Yes. There is no sweeter melon than the Large Montreal, which all travelers to Canada never cease to dwell upon. The sweetness depends more upon soil, long hours of daylight, atmospheric conditions and variety than upon size.

Onions. $\quad$ 521. Q. What causes stiff-necked onions?

A. If the entire crop is stiff-necked it may be attributed to a want of such fertilizer, natural or artificial, as is desirable to stimulate quick development of crop, or it may be imported seed. If only a per cent. is stiff. necked it may be attributed to thick seeding, or to a mixed lot of seed.

Asparagus. 522. Q. My asparagus beả is now seven years old and good as ever; how long may I expect it to continue productive?

A. If the bed is properly plowed and cleaned, and top-fertilized every autumn, it should last for five or six years more. Salt at the rate of five bushels to the acre is good for asparagus, it stimulates the asparagus, a salt plant, and retards weeds.

Wheat. 523. Q. How many times will wheat start and stop, and start and stop, and start again?

A. Five or six times-seemingly a provision of nature to fit the most important cereal for growth under adverse circumstances. No other seed has this quality to so notable a degree. Oats, rye and barley possess it to a less extent.

Top Onion. 524. Q. How can I distinguish the True Top onion from the False sort? A. By cutting the sets transversely-that is, across or between crown and bottom. If the True Top set, only one heart will be seen; but if the False set, often three or four hearts will be scen, and when such a set is planted each heart makes a sct. 
525. Q. Is it true that melon seeds several years old are usually more old Melon productive than fresh seed?

Seed.

A. It is true; and the reason is that fresh seeds have often so much vigor that the plants produce little but stems and leaves, while old seeds of less vigor put.out many blossoms which set and develop fruit, all borne upon short.jointed vines.

526. Q. Why don't cauliflower flourish equally with cabbage?

A. Because cabbage will grow in any locality where the soil is good and the manuring sufticient, but cauliflower requires particular conditions, flourishing best in a humid and salt atmosphere.

527. Q. Is there any vegetable growth which appears to be animal. Fungus.

A. Yes; several. One quite common in some gardens is that fungus which develops the club root in cabbage, turnip and carrot. The spores have tail.like appendages which by vibration move along over wet surfaces in a life-like manner.

528. Q. What is the best all-around fertilizer for vegetables?

Stable

A. Well-rotted stable manure from corn-fed and well-kept horses. Mranure.

It contains all the ingredients necessary to a perfectly satisfactory growth.

529. Q. Which is the superior for cattle feeding-beets, carrots or Beets. turnips?

A. Turnips are the least nutritious, but the quickest and cheapest to produce. Carrots are very fattening, but are expensive, and they require much attention. Beets, more properly Mangold, are the most bulky pro. ducers, are rich in sugar and are easily harvested and preserved. They are the best for cattle food.

530. Q. Can a trucker rely upon phospluates to develop his crops?

A. Yes; if the soil contains nitrates and potash from previous manurPhosphate。

ings. Most commercial superphosphates contain valuable proportions of nitrogen and often some potash. Heavy soils should have stable manure or green crops plowed under to lighten them. Commercial fertilizers do not aerate the soil ; under their continued use soils become very hard.

531. Q. Does potash help in growing sweet corn?

A. Certainly. Wood ashes, it is well known by all farmers, has been found very effective as a fertilizer to corn crops. But it is not a stimulant to early growth, is only felt very late in the season.

532. Q. How can I rid my land of white grubs?

Grubs.

A. Apply lime and salt, and plow deeply just after frost, and turn the furrow slices upside down so that hard frost may kill the pupa of all insects awaiting the return of spring.

533. Q. Why do wriukled varieties of peas mildew more than hard, Pea Mildew. round-seeded sorts?

A. Mildew is a cryptogamic development which for some reason occurs more frequently upon broad-leaved peas than on those of smaller foliage. Early peas hardening their foliage carly do not afford so favorable a field for the spread of the fungus. 
Cabbage

Worms.

\section{Cauliflower.} successfully as I formerly did on Cape Cod?

A. Because of deficiency of humidity in the air-particularly because of want of salt in the atmospherc and partially because of want of salt in the soil. Cauliflower is of the cabbage family-a salt water plant-and seems particularly to flourish in salt-air districts. Try it on a meadow.

Hog Manure. 537. Q. Why does hog manure cause the soil of gardens to produce wormy vegetables and club root cabbage?

A. Because the rich manure attracts flying insects to deposit their eggs -the grub from which eat anything and everything green, soft and juicy. The same over-rich masses of manure develop fungous growths, and club root in cabbage is a result of fungus.

Radishes. 538. Q. Why is it that some soils won't grow radishes?

A. Radishes will grow, but not good ones, on soils affected with grubs, worms, ants. These conditions are brought about by the use of pig manure or night soil.

Potatoes. 539. Q. Why are some potatoes soggy while others, grown same season in same locality, are dry and mealy?

A. Some varieties of potato are never mealy; and sometimes the choicest sorts are soggy on account of unfavorable soil or season.

Periods for Sowing.

540. Q. In making repeated sowings during Summer and Autumn of seeds for kitchen garden, how late can I continue to sow?

A. Firstly, determine the average dates of slight frost in Autumn and of killing frost. Secondly, divide your vegetables into the two classes of those which will at once succumb under first frost and those which will recover and continue growth till the killing frost. Among the first will bc vines, beans, egg-plants, okro, corn ; among the second, lettuce, spinach, kale, turnip, cabbage. Thirdly, observe the time required in each instance to mature for table use and plant accordingly.

Oniou 541. Q. I drilled two patches with your Strasburg Yellow onion seeds Germination. for sets, sixty pounds to the acre. One quickly developed finely formed sets; the other dragged along and finally resulted in almost a complete failure. Why was this?

A. This often happens, and is a consequence of conditions, sometimes of soil and atmosphere, sometimes of period of sowing, oftener from insect or fungous ravages.

Rusty Beans. 542. Q. Will beans saved from a crop of rusted beans produce in their turn a crop of rusty beans? 
A. Quite possible if the season is a damp one. A preventive is to give the seed a bath for an hour or two in Bordeaux mixture just before planting.

543. Q. What is the right time to remove suckers from sugar corn? Corn Suckers

A. Just before coming into blossom, if you must do it; but let them alone and save yourself trouble. The sorts which sucker most are the heaviest yielders. Suckers do not reduce the erop of ears, but the removal of the suckers reduces the bulk of dry forage.

544. Q. How many bushels of marketable onions can be grown to the Onions. acre?

A. Five hundred to six hundred bushels is an excellent crop, but eight hundred is common and twice that number have been reported.

545. Q. Why do early varieties of corn smut more than late sorts? Corn Smut.

A. Because they have less vigor of constitution.

546. Q. Is Peruvian guano a perfect manure?

Guano.

A. That depends upon its grade. When of first quality it certainly is an effective fertilizer, but is more a stimulant than a perfect manure, as a thoroughly efficient manure continues to supplement itself over a long period; this the Peruvian guano does not.

547. Q. Should an asparagus bed be allowed to go to seed?

Asparagus.

A. Yes; that is only natural. The plants if not permitted to develop bush and seed would be unhealthy. After frost kills the vines cut them off.

548. Q. What makes radishes pithy?

A. Generally a want of proper nutrition; on fairly rich land, where the plants grow quickly, the roots will always be solid.

549. Q. Why is it that cucumber growers who ship slicing cucumbers cucumbers prefer the White Spine?

A. Because the White Spine is a good producer and because it retains Shipping. its green color during the period of shipment. That is all, and it is enough.

550. Q. Can the watermelon be enlarged in size by hybridizing it with Watermelon, the pumpkin?

A. Yes. The market gardeners of New Jersey understood this years ago, and they frequently planted a few Mammoth pumpkins in their watermelon patches that they might produce seed which the following year would produce Mammoth watermelons. This, however, was always done at the expense of quality.

551. Q. Will squash and pumplin hybridize?

A. Yes; but only occasionally; not nearly so freely as supposed by tion. those who have a smattering of scientific knowledge. When these families do hybridize the results are wild or unfixed in habit, and sometimes the seed from such hybrids will not germinate. Watermelons will mix very occasionally with pumpkins same as squash.

552. Q. Is agriculture a science or an art?

A. It is an art, aided and abetted by science; chemistry, mineralogy, what is it? physiology, botany and entomology all being drawn upon to demonstrate the development or retardation of vegetable species. 
Botany. 553. Q. Is botany strictly a science?

A. In general terms it is, but not altogether an exact one, as much must be taken upon the evidence of others, it being impossible for any one man or any body of men to have seen and examined all of the one hundred and fifty thousand species of known plants. In other sciences the observations of the discoverer can be confirmed, but not always so in botany.

Scientific

Agriculture.

554. Q. Is agriculture or horticulture a study presenting much diversity?

A. No study, taken in a scientific aspect, covers so wide a field, or one the limits of which are so impossible to attain, as all calculations are disturbed by fluctuations in climatic or soil conditions.

Agricultural 555. Q. Will the agricultural practice of the future be an improvement Development on that of the past?

A. Certainly ; for the intelligent practice of agriculture is now guided by science, and in the future it will be ruled by it. Unfortunately, but a small proportion of agriculturists will possess scientific intelligence, and consequently the practices and errors of the past will be continued by the great majority. There will be three classes of agriculturists: the altogether unscientific, the practical cultivator with some scientific attainments, and the scientific theorist without practical experience or capacity for making things pay. The agricultural experimental stations have done more in the past twenty years to disseminate scientific knowledge of the action of fertilizers, plant diseases and cures, injurious insects and methods of destroying them, than any agency which ever existed. Agriculture is becoming scientific, but it can never be entirely so, as no method or system can be depended upon to produce a fixed result, consequent upon the uncertain effect of meteorological happenings. No art will call to its aid to interpret it so many scientific branches as agriculture, but all that will never make it a perfect science, on account of the unfixed quantity of heat and cold, rain or drought, the variations of which defeat all calculations.

Onion Sets. 556. Q. Can I do best by Autumn planting in the high lands of Texas with onion seed or sets?

A. Better plant sets, twelve bushels to the acre, in rows at fifteen inches apart. Set out in November, they should mature for sale in March. Seed drilled in October would probably be injured by frost.

Drilled Seed. 557. Q. Is it best when sowing turnip seed to put it in with a seed drill, iu rows, or to broadcast it?

A. It is quickest, cheapest and simplest to broadcast it, but a better practice is to drill it, as drilled seed is put down more deeply into the soil, and is therefore able to resist drought under conditions when broadeasted surface-sown seed would dry up and die.

Cabbage. 558. Q. Will cabbage plants head if the seed is sown where the plants are to stand?

A. Yes, a portion will head; sometimes eighty per cent. will head.' At 
other times not over twenty per cent. Cabbages to head properly need a check in their continuity of growth, that is, to have a rest as it were, when all growth ceases for a time, as is the case when they are taken up from a seed bed and transplanted to the field. To attempt to grow a crop of cabbage with the idea of getting heads for sale or use without transplanting is a very unsatisfactory system. It is a lazy man's practice, and he who pursues it gets as much as he deserves for his want of energy.

559. Q. What is the best method to exterminate those noxious weeds which propagate from the root?

A. The Canada thistle is the worst example of these. The above-sur-Weeds. face part to the ordinary observer appears to be an annual, but the root is perennial and extends down to about eight inches, and then horizontally branches out in various directions, forming on its horizontal branches buds which send up to the surface apparently new plants the next year. On small areas it can be dug out or killed with lime or salt, but upon broad fields the most efficient system to destroy it is by constant working so as to cut off its air supply. It is just such treatment as should be given to all weeds having persistent underground roots.

560. Q. I have the onion maggot every year in my onion sets. Can I parevent it?

A. Not entirely, as the insects which deposit the eggs when the onion Onion seedlings are about two inches high are then flying from field to field. Maggot. You can, however, kill off a portion of the larvæ from which these insects are developed by burning straw or trash upon your proposed onion patch. To do it efficiently a deep mass of burning material will have to be used, or only those larvæ that lay within one inch of the surface will be scorched. Another way to kill the larva is by the application of about 400 pounds of nitrate of soda to the acre, or about 600 pounds of kainit. Onions like salt.

561. Q. Is there any rule by which a novice can distinguish the sex of Sexes in garden vegetables? If so, please give it.

Vegetables.

A. Most garden vegetables can be divided sexually into three classes :

1. Those in which the sexes occur in the same blossom, as in the cab. bage or beet.

2. Those in which the sexes occur in distinct blossoms on the same plant, as watermelon, squash, corn.

3. Those in which the sexes occur on distinct plants, as spinach.

When any of the plants are in bloom a very little study by an observant and intelligent man will indicate the class to which they belong, as it is very easy, as a rule, to distinguish stamens, the male organs, from pistils, the female organs.

562. Q. What is the value of millet?

A. The three or four distinct types of millet as ordinarily cultivated make very good fodder crops for feeding green, and when cut before the stalks get old and hard make good hay. Millet can be mowed for hay sixty to seventy days from sowing. There is a popular objection to 
Tomato Fungus.

Popcorn.

Egg Plants.

Mustard.

Corn

Quality.

millet as hay on account of the belief that the small, hard, dry seeds are swallowed by horses without mastication and cause inflammation of the bowels, but millet intended for hay should never be allowed to harden its sced before cutting, as at that period its foliage has lost much of its value for liay.

563. Q. What is the cause of the black spot on the fruit of my tomato plauts?

A. Fungous growth which devclops at the blossom end of the fruit, located there probably because the skin is more tender there. The attack is most generally in wet or damp seasons. The disease once established on a fruit extends its area of surface and eats deep in the fruit, soon ren. dering it worthless. Bordeaux mixture is efficient at first to prevent or arrest the disease, but it can only be used early in the life of the crop, and as a precaution against the disease, for being a poison it cannot be used on plants bearing fruit ready for consumption.

564. Q. What makes popcorn pop?

A. Take a grain of popeorn, or any corn, and cut it down through the middle, exposing the broad surface from top to bottom, and there will be observed at the small end, the clit, or germinating part, and surrounding it to a greater or less extent and extending up to the centre of the grain sometimes to the top will be observed more or less white starchy matter, and on both sides and sometimes above it a deposit of oily matter. Now it is this oily matter which when heated explodes and turns the grain inside out. Popcorn in proportion to its size develops more oily matter than ordinary field corn, and consequently explodes more violently. Any other corn with as much oil in it as pop would do as well.

565. Q. Last year my egg plants were borne down with fruit, but this year they don't average two fruit to a bush. How is this?

A. Most likely due to imperfect pollination. In the egg plant the sexes are both found in the same flower, but sometimes pollination docs not occur sc freely as at others due to conditions of rain-fall, or fog, or low temper ıture. In some cases, or in small patches, it would pay to pollinize by hand, which work can be donequickly with the point of a knife.

$56^{\prime}$ j. Q. Among my turnips on a large three-acre field there appears to be 'sbout twenty per cent. of mustard. One of my neighbors says it is fr $m$ a crop which went to seed on the same land five years ago. Can tilis be so?

A. Certainly, and the seed may continue to come up for five years more. Mustard being very retentive in vitality many seeds plowed down six and seven inches by the plow will not sprout in years till brought to the surface by a plowing deep enough to reach them and expose them to the influence of the atmosphere.

567. Q. What constitutes a good type of corn?

A. Adaptability to location, productiveness, a small cob to dry out quickly, length of ear resulting in diminished labor in lhusking and shelling, depth of kernel, and closeness of packing upon the grain, salable color and weight. 
568. Q. Is there any manurial value in leaf-rakings from woodlands? Leaf-rakings

A. Very little active value, though it is the basis of humus. Ordinarily it is hardly worth the labor of hauling, except for bedding for pigs in pens, or in a barnyard. Under those conditions it is excellent as an absorbent.

569. Q. Is intense cold destructive to the vitality of seeds?

Seed,

A. If the seeds be dry and well-covered it seldom injuriously affects vitality. vitality. Wheat taken by a North Pole exploring expedition as far north as 810 , and left there through five winters where the temperature for months stood at $50^{\circ}$ and 600 degrees below zero, germinated freely when brought to temperate climates. On the other hand few seeds will stand for any time a heated temperature over $1500 \mathrm{~F}$.

570. Q. I have heard of big crops of corn, but never was able to grow Corn Crops. over fifty bushels of shelled grain to the acre, and would like to know how some people who claim to have grown over 100 bushels of shelled grain have accomplished it?

A. It is only done on strong ground, yet not so strong as to throw all the energy of the plant into making leaf. If a corn field is planted in hills at $3 \frac{1}{2} \times 3 \frac{1}{2}$ feet, and each hill has four stalks producing one ear to each stalk and shelling seven ounces to the ear, the yield would be 110 bushels to the acre. Not infrequently a hill of four stalks will produce three to five pounds of shelled corn.

571. Q. I have a never-failing stream of water passing through my Fish Culture. farm and write to inquire if the duties of farming and fish culture would conflict, and if there is any profit in fish culture.

A. There is a good profit in fish culture to those who understand it, but nine out of ten fail to realize a profit for a want of the knowledge of the requirements to insure success. Hundreds of New England farmers have profitable fish ponds, and the labor of caring for them does not conflict with their agricultural operations.

572. Q. Why are some perfectly new seeds unvital?

A. It is attributable to a failure of pollination, and the failure to polli. nize may be due to want of a vitality on the part of either the male or female plant, or to continued rain or a series of very damp heavy days interfering with the transfer or reception of the pollen. This is noticed more particularly with the seed of plants in which the sexes are found in distinct flowers, or distinct plants as corn, melons and spinach. Nearly all perfectly new seeds contain a varying percentage of such unvital seeds, generally light, small and stunted, but sometimes as plump as any.

573. Q. Is the heading of cabbage a natural habit of the plant, or is it Cabbage. an abnormal condition brought about by cultivation.

A. Not by cultivation, but entirely by selection, covering hundreds of years. Heredity in the cabbage originally was in the line of development of producing a mass of loose spreading leaves, as in the dandelion, but by the selecting of those plants most productive in leaves and most dense, a habit was finally formed which became in time a beredity more torcible 
than the previous heredity to form flat open centres. This new habit of forming a rosette-like head became stronger and stronger till a plant was developed in which the heading habit was its chief characteristic.

Lettuce.

Firming the Soil.

Pearl Sets.

Cabbage.

Imported Cabbage Seed.
574. Q. I have trouble in getting a good head of lettuce. Which is the best way to sow it, and how deep should it be covered?

A. If the seed is good, that is vital, there should not be any trouble if it be properly sown. Of course if the seed is put into the ground and covered deeply, only a portion will ever show a sprout above the surface. It should never be put into the earth, only put on to it and slightly scratched with a rake, or better still, patted down with a board, or tramped down lightly by pressing with the foot every square inch of the bed surface.

575. Q. How can I most rapidly compress seed sown in rows after having finished drilling it in the field?

A. Roll it with a farm roller, or wheel a wheelbarrow with a broad tire both up and down each row and directly upon the top of each drill mark. The seed so compressed will sprout first.

576. Q. You recommend the Bloomsdale Extra Early Pearl Sets for Autumn planting in the South. Will you advise me what degree of frost they will stand. Here in North Carolina we sometimes have some very severe weather, but it is of short duration. If they need protection, how can I protect them?

A. They will stand a zero temperature without injury if it be only for a few hours, and if they be well rooted, that is, if they have taken hold of the soil before their grow th was stopped. We have many times had them standing out all Winter on Bloomsdale when the temperature often went below zero. They are full proof against 200 frost, that is when the mercury falls to $10^{\circ} \mathrm{F}$. They can be protected by hay, straw, pine shatters, but all this kind of covering affords a harbor for mice, squirrel and other vermin to feed upon the bulbs.

577. Q. What is the reason I have so much trouble in growing good cabbage. I get the very best seed I can purchase, and make my seed bed just as rich and fertile as possible, yet the plants do not grow or head well when put out in the field?

A. Your question, perhaps, answers itself, for you say you grow your plants on a ricls and fertile seed bed, and that is where the difficulty probably comes in. Plants should never be grown on a richer soil than that to which they are to be removed, otherwise they at once upon transplantation become starved and in ill health. Moved from a poor seed bed to a field richer than the bed they at once become invigorated and healthy.

578. Q. I have been using cabbage seed which I have imported from Europe for several years, and I find that in a moist season I can grow fine cabbage, while in a dry season they are a total failure. What is the reason?

$\Lambda$. Because the strain is not acclimated. During a wet season the conditions resemble those of Europe, but when an American dry spell sets in 
the plants from the foreign-grown seed at once meet with a new condition and failure results. This being the case, and no one knowing what the season will be, it is injudicious to plant foreign seed, as a loss of an entire crop may result with its expense of cultivation. American seed from thoroughly acclimated stock will do well during either wet or dry weather.

579. Q. How must I grow cabbage plants to keep over Winter in cold frame? In my section the mercury often falls to zero.

A. In the latitude of Philadelphia where the mercury often falls below zero the seed is broadeasted in the open ground about September 1, and when two inches in height transplanted into cold frames, that they may take hold of the earth early and become four inches high before hard frost stops their growth. In the cold frames the plants are set, deeply at about one inch apart. The frames are covered with shutters or boards, which are removed to give light and air on fine days.

580. Q. My gardener says my egg plants have damped off. What does Egg Plant that imply?

Damp.

A. That the tissues of their roots or stems have been destroyed by a parasitic plant, the growth of which has possibly been induced by repeated conditions of damp soil and damp air and not enough ventilation, followed at times by too high a temperature. There are a number of species of fungi causing a similar decay of young seedlings of tomatoes, peppers, cabbage and lettuce. Some confined generally to under-glass culture, others occurring in the open field.

581. Q. My cabbage are infested with the calico bug. What remedy Calico Bug. can I take to drive them off?

A. They won't drive: nothing but hand-picking and crushing is an effective treatment. The writer knows it, for he has had to do it in the course of many years with thousands of acres of cabbage and turnip preyed upon by this bug. The insect is also called the terrapin bug and the harlequin bug. It is a sap sucker, consequently Paris green won't effect it, or no other outward poison. Oil or emulsions have very little influence upon it, and it is a most serious pest.

582. Q. What is that disease of the tomato affecting the leaves and stem, Tomato Curl. causing the leaves to curl and finally die?

A. There are several diseases causing tomato leaves to curl. One most general is termed the tomato œdema, caused, it is thought, by an excessive rain, a high temperature of the soil, making the roots active in pumping up water and insufficient light to induce free transpiration, the result being an unequal swelling of certain parts and bursting of the tissues, and a general weakening of the plant, resulting in the death of entire branches.

583. Q. Are vegetables grown on naturally rich soil better in flavor Flavor. than those grown on worn-out soil made productive by the application of fertilizers?

A. Grown on rich origin soil the development in size seems to be at the expense of fine texture, flavor and good-keeping qualities, while grown on well-used soil, the development is less rapid, but the flavor is better. 
Weods.

Winter

Cabbage.

Weevil.

IBean Weevil.
584. Q. Why do most weeds grow faster than the eultivated plants of a garden?

A. Bad stocks of all created life, both animal and vegetable, seem to be endowed with special reproductive and sustaining powers. The common weeds of the field are generally annuals, and, sprouting after the intended crop is put in, frequently after it has received its first and second cultivation, the weeds must of necessity be of exceedingly rapid growth to mature their seed by the time the regular crop is ready for harvesting. Few slow.growing weeds ever arrive at a stage to develop vital seeds, but the quick-growing ones do, and it is with the seeds of such that the soil is charged. Weed seeds seem to have greater power of retention of germinating qualities than seeds of cultivated plants. It is those of very strong germination which are most common. Few seeds of garden vegetables will sprout when but quarter of the age of the seeds of common weeds.

585. Q. If I sow my cabbage seed in September, broadeast, and get them three inches high by hard frost, can I protect them over Winter by covering with straw?

A. This has been tried frequently, but is generally a failure; the straw is pressed down by snow and the cabbage rots off. Poles placed flat on the ground throughout the cabbage would support the snow-covered straw and probably be found of advantage.

586. Q. What is the hardiest cabbage for sowing in September to keep over Winter?

A. Bloomsdale Early Dwarf Flat Dutch is the hardiest. It is a flat header, not so early as Jersey Wakefield by three weeks, but a better cold resister. A hardy sort, maturing between these two, is the Bloomsdale Large York, forming a head similar in shape to the Wakefield but twice as large.

587. Q. My barn is full of wheat weevil. How can I get rid of them?

A. There are four or five insects which, in unscientific language, are referred to as wheat and corn weevil. One is a moth and exeeedingly destructive to stored grain, the caterpillar of which is white and about two-fifths of an inch in length. Two other grain insects are small red beetles, but of distinct species, and a fourth is the black or true granary weevil, about one-eighth of an inch long. All these ean be partially de. stroyed by subjecting the grain to the fumes of carbon bisulphide. When the mature insects are found harboring in the cracks and crevices of barns they can be destroyed by copious soakings with kerosene oil.

588. Q. When I lived in Pennsylvania I grew large quantities of grocery beans, but cannot down here in Carolina as they become full of bugs. Is there any remedy?

$\Lambda$. No; you will have to turn to other crops. The mature female insect, of the bean weevil deposits her eggs in a slit which she makes on the pods when the bean pods are very small. The eggs hatch and the grubs strike for the dark, eating their way through the pod and into the soft green beans, where they transform to winged insects. As the bean 
weevil deposits many eggs in one place, many beans will contain six or seven grubs. The pea weevil only deposits one egg in a place.

589. Q. What is implied by humidity of the atmosphere?

A. The air will take up and hold invisibly a certain amount of moisture; a greater amount will appear as mist, fog, or rain and fall to the ground. The full amount of moisture that the air will hold in perfect suspension and invisible is, for scientific purposes, estimated at 100 , half that quan. tity at 50 . When the humidity is reported at 90 the air has almost ceased to be able to take up perspiration from the human body; consequently the atmosphere is very oppressive, even though the temperature may not be above $800 \mathrm{~F}$. Instruments to indicate humidity can be bought for two or three dollars and are instructive and useful, same as thermometers.

590. Q. What was the biggest crop of corn ever grown in the United Corn Crop. States?

A. The crop of 1889 was $2,162,892,000$ bushels. The estimated crop of 1895 is $2,425,000,000$ bushels, from $82,000,000$ acres.

591. Q. Are there any Bast fibre plants native to the Middle States Fibre Plants. which I can experiment with for fibre?

A. Yes, two very promising ones.

1. The Swamp Rose Mallow, a perennial naturally growing in swamps and producing straight stems to a height of six feet, but growing just as well on upland. Its fibre is a substitute for jute.

2. The Abutilon or Butter plant, an annual found in nearly all cornfields and growing, in ninety days, to a height of four to five feet. It produces a fibre strong, white, glossy, and a good substitute for jute. It can be grown wherever Indian corn can be grown.

592. Q. How much Orchard grass seed is grown annually?

A. About three million pounds, nearly half of which is sent to Europe. Grass. The production ranges from five to fifteen bushels of fourteen pounds to the acre. It is mostly grown in Kentucky and Virginia.

593. Q. What is the difference between Spring and Winter wheat?

A. Spring wheat, an annual, is an abnormal form developed by selection and climatic conditions from Winter wheat. All wheat, in early times, was of the biennial habit. In extremely cold sections of country Winter wheat often kills out, and in suclı parts Spring wheat is cultivated to advantage.

594. Q. Is a bearded or beardless wheat the best?

Wheat.

A. Opinions vary upon this subject. A bearded wheat bends over and breaks down sooner than a bald wheat, as it holds a greater weight of rain. On the other hand it is more self-proteetive against the ravages of birds.

595. Q. In shipping beans to the Northern markets I frequently receive Bean Rust. reports that they have arrived badly spotted or rusted and therefore unsalable, though I know they were perfectly free from spots when they were packed. Can you explain this?

A. Probably due to the natural moisture of the pods when packed, 
Red Color Mystical.

Forest Growth.

Celery Blight.

Celery in the South.

Ergot.

Fertilizing.

Moon's

Influence. which developed heat and greatly extended the growth of some fungous disease already on the pods. This result can be partially avoided by dry. ing and airing the pods under cover in a cool place, as on tables in a shed. No vegetable should be shipped direct from the field until it is cooled off.

596. Q. Why do country horsemen and stable boys tie up the tails of their horses with red cloth?

A. It is an old tradition that red is the proper thing to use, the color being a mystical safeguard against evil spirits. They don't do it for this purpose, but simply because it is the practice.

597. Q. Does soft wood-as pine-or hard wood-as oak and chestnutindicate the agricultural qualities of land?

A. Not always; for many sections of country, without any change in soil, naturally develop both, hard and soft forests following each other. Two hundred years ago the State of Dclaware was covered with hard woods, and no oak was superior then, or is now, to the oak of Delaware; but large sections where oak was cut off, pines followed, and the soil is the same now as then.

598. Q. What causes the blight in celery?

A. It is caused by a parasitic fungus. A preventive sometimes used before the celery crop is planted is kainit. This should be applied not only to the field but to the seed bed.

599. Q. Why cannot I grow celery at Savannah as successfully as I formerly did at Easton, Pa.?

A. You can, provided your soil and location is of the proper kind, as celery is successfully grown as far South as Tampa, Fla. As for the soil, it should be rich and mucky; as for the location, it should be upon land where a constant understrata of water is near the surface. Celery is a bog plant, and should do in many locations on rice plantations, and so should cauliflower. It would be found advantageous to shade celery by alternate rows of corn or sunflower.

600. Q. What is ergot on rye?

A. A fungus attacking the grain when quite young, producing a horny growth of disagreeable odor and quite poisonous. When ergoted grain is used for making meal it always develops sickness and sometimes produces convulsions, gangrene, and often death.

601. Q. Can vegetables be fertilized through their foliage?

A. Not in the open garden, but to a small extent in glass houses, by making an artificial atmosphere charged slightly with carbonate of am. monia.

602. Q. I want to put a new shingle roof upon my barn and my country carpenter tells me I should only do it during the decline of the moon. Is there any force in this?

A. The proper time to shingle a roof, to plant seed, or to kill pork is just when you are rendy. All these old-fashioned ideas about the influence of the moon are exploded, except in the opinions of a few old-fashioned 
country people. These belicve, as their ancestors did, that shingles put upon a roof in the decline of the moon would hold down and lay flat, but laid on the increase of the moon would rise up and curl. Some years ago a Commissioner of Agriculture, in office at Washington, told the writer that he believed in all signs as regulating farm operations; that he always killed beef and pork and planted secds during the proper phases of the moon, and that even a worm fence put up during the decline of the moon would stand twice as long as one set during the increase.

603. Q. I have some seeds of a very choice watermelon, saved twenty watermelon years ago. Will they sprout?

Seed Vitality.

A. Keep a portion of tliem in a weak solution of chlorine, another portion in a solution of oxalic acid, and sow both in a well-prepared seed bed, kept damp, but not wet. A remaining pórtion fold in a woolen cloth saturated with oxalic acid, and kecp warm near a stove. If any germs appear put the seed at once into eartl.

604. Q. My canteloupe vines bearing nearly full-sized fruits are drying Canteloupe up. What is the cause?

Diseases.

A. If the drying is in spots it may be from a fungous attack, but if it is all over the patch and affects all parts of the vine it is either due to defective nutrition or to drought. Canteloupes should be deeply plowed when last worked; at that time the plow is the proper implement, the cultivator is little good, as the soil should be deeply moved and plenty of it thrown up to the roots before laying the crop aside.

605. Q. Can I successfully grow garden peas on the same land for Peas. several years consecutively?

A. Yes, if the land be well fertilized with potash, phosphoric acid and nitrogen. It will, however, be best to rotate all crops, each requiring a difference in soil foods, some a radical difference, others only a slight difference, all taking some, some more, some less, of each food constituent.

606. Q. Are turnips for stock food better than mangels, beets or carrots? Turnips.

A. Turnips are not so nutritious, nor so long-keeping as bcets or carrots, but can he grown at half the expense of labor, and requiring only a little over one-half the time from sowing to full development.

607. Q. What is the onion smut?

Onion Smut.

A. A fungus, very minute, and cousisting of small filaments or threads formed within the folds of the onion leaves. This fungus when quite developed bursts the leaves longitudinally, exhibiting long lines of black dust, which are spores set forth to further cxtend the disease. Once located upon a field the only way to get rid of it is to cease raising onions on that field. It is contagious; healthy parts of the field being inoculated by the smut carried on tools used in working the affected parts.

608. Q. Which is the most moncy-producing agricultural State of the Richest Union?

A. New Jersey, which State, considering its acreage under cultivation, State. produces more dollars' worth to the acre than any other State. This is a 
consequence of its general level surface, and its intermediate location between the great consuming cities of Philadelphia and New York, and its influx of Summer visitors along its Atlantic coast, all requiring the best of all vegetables and in immense quantities.

Spring 609. Q. What plants besides Seven Top and Dixie turnip will do well Greens. in Alabama for early Spring greens?

A. Cabbaging dandelion, Long French sorrel, chickory and Southern Snow White turuips.

Transplant- 610. Q. What sorts of vegetables should be transplanted to stimulate ing. their more perfect development?

A. The transplanting of vegetables cannot be practiced so generally and so systematically in the United States as in the moist countries of France, Germany and England. In those countries nearly everything can be transplanted successfully and to advantage.

As a rule it is advantageous to transplant lettuce, cabbage, kale, cauliflower, celery, tomatoes, egg plants and peppers.

Air Plants. 611. Q. What are air plants?

A. An order generally found growing upon the trunks and branches of trees.

Air plants do not draw any nourishment from the trees, consequently they grow equally well on dead ones as on live ones, drawing all the nourishment from the air. Familiar examples are found in the very ornamental hothouse orchids, and in the long moss of southern forests.

Moisture

Absorbed.

Cold Frame. 613. Q. What is a cold frame?

A. A box of any size or shape set down upon a suitable bed of natural soil. The box sometimes covered with a window sash or other glass frame, sometimes only with a shutter or loose boards. A glass frame adds to the warmth of the soil beneath, a shutter or boards protects the soil and the contents of the box from injurious effects of rain, cold, or snow.

In ordinary practice a frame is made of sixteen-foot boards placed parallel and about six feet apart, the ends closed with other boards.

A cold frame is so called because it is not a hot one, there being no manure beneath to develop what is called bottom heat.

Phylloxera. 614. Q. On what kind of soil is the phylloxera least destructive to the grapevine?

A. On sandy soils, as such soils hold less air and more water, which is prejudicial to the rapid increase and development of the insect. Sandy soils asphyxiates them. 
615. Q. Why are American grape vines so largely planted in European American vineyards, and why are European sorts so seldom planted in America. Grape.

A. The roots of $\Lambda$ merican varieties have greater resistent powers against the phylloxera. The sorts used are selections from the oestivalis, riparia, labrusca, and some few are from the wild forms of Rupestris cordifolia, cinerea, Berlandieri. European sorts having very little resistent power are not much used in this country, as they soon become unhealthy and die.

616. Q. On my farm are two distinct qualities of soil, one section being Influence loam, the other sand, and curious to understand, the plants in the sand of Sand. resist drought the best. Why is this?

A. On a sandy soil water either derived from above as rain, or from beneath by the action of the sun, lodges in the interstices between the grains of sand and forces the air out, and in this way a sandy soil may hold a large amount of water.

617. Q. What is the grape insect known as phylloxera?

A. It originally came from the Mississippi Valley, and was discovered about 1854. Between 1870 and 1880 a large portion of the vineyards of France and Spain was destroyed by it, and subsequently the vineyards of all Europe were seriously affected. It is believed the insect was taken to Europe attached to roots of American vines.

Up to 1884 over two million acres of vineyards had been destroyed in France, and one million more injuriously affected. A loss estimated at $\$ 140,000,000$. The mature insect hatches out upon the young roots of the grape in June, and works its way through the earth to the surface to fly away and extend its species.

Lighting upon young grape leaves, it deposits its eggs, which form leaf galls. The grubs hatched in these galls immediately lay other eggs, sometimes two or three hundred, the larvæ from which drop to the earth and, penetrating it, are ready in the Spring to affix themselves to the roots. These larvæ form nodules on the rootlets, and deposit about one hundred eggs, to hatch out and recommence in June the round of transformations just described. The most efficient remedy is to saturate the soil about the vines with the fumes of bisulphide of carbon, about three hundred pounds to the acre. This is done by pumps with small penetrating tubes to be forced down among the roots. Flooding or sub. mersion to a depth of twelve inches for a period of ten days is beneficial in October or May.

618. Q. What is corn smut?

A. A minute parasitic plant, seldom seen till after some weeks of growth within the close envelope of the ear, when it bursts out in a black mass. There is no remedy to arrest its growth while saving the ear. Possibly soaking the seed corn in blue vitrol might be a preventive.

619. Q. Is there any fertilizing value in grcen oats or rye plowed under? Green

A. Yes, to an extent; but not so much as derived from crimson clover Manuring. or cuw peas. There is no object in laising rye or oats to plow under, 
except that the two crops can be grown so much more quickly than clover or peas.

Tomato Shipping.

Mule Plant.

Cross-bred Flant.

Sun House.

Asparagus.

\section{Potato} Cultivation.
620. Q. I frequently have received reports from my commission merchant in St. Louis that the tomatoes I have sent him, and which I know were perfect wheu I shipped them, arrived in a decaying condition. Can you give me any reason for this?

A. Tomatoes which are picked during the heat of the day and packed without being allowed to cool thoroughly are almost certain to spoil in a day or so. It is just so with beans, and in fact with all vegetables. They all should be cooled off. Your commission merchant may be right and you may only have yourself to blame.

621. Q. What is a mule plaut?

A. A progeny from the fertilization of the pistil or female organ of one species of plant by the pollen from them ale organ of a distinct species of plant. Two species of the same genus may be thus mixed, but it is uncommon for them to produce seed. They are most generally sterile, but not always, for among garden vegetables the cucumber and the melon have been crossed and the seed has been fertile.

622. Q. What is a cross-bred plant?

A. A plant raised from seed the product of a variety of some plant of one species the pistil of which has been fertilized by pollen from a flower of another plant of the same species. As, for example, a red tomato crossed with a yellow tomato.

623. Q. What is a sun house?

A. A structure on the same principle as a glass-covered cold frame, only larger. It is like a greenhouse without artificial heat, depending altogether on sun heat derived during the day and which it partially holds during the night. In early Spring and late Autumn it protects growing plants from frost, beating rains, and snow. Such houses are found profit. able to market gardeners.

624. Q. Is asparagus best when cut under the surface and white, or when allowed to rise above the surface and become all green ?

A. Simply a matter of taste. Cut above the surface, three times as many bunches can be cut from a bed as when cut beneath the surface. The cutting underground destroys many shoots not in sight. For can. ners' use it must be cut under the surface, as when it gets green it becomes too soft to stand the processes of canning.

625. Q. I have looked in vain through your catalogue to find out how far apart I should plant potatoes. I suppose every farmer knows all about it, but I am not a farmer. I want to raise about ten bushels.

A. If an acre of potatoes averages 150 bushels, then one-fifteenth of an acre would be required to produce ten bushels. Now a fifteenth is about 325 square yards, which is, say, forty yards long by eight yards wide. For a small plot like this plow the land, harrow, and open trenches five inches deep and two and one-half feet apart. Place the potato cuttings about eight inches apart and cover with three inches of soil. The culti- 
vating and the rain will, after a time, wash down the whole thing to a level. Previous to plowing, the land slould be top-dressed with a full cartload of well-rotted stable manure, or treated with forty pounds good commercial fertilizer.

626. Q. I find Ivy on the walls of a farmhouse I just purchased. Will Ivy. it keep the walls dainp?

A. It will keep them dry, as the leaves overiap each other like shingles so that not a drop of rain can strike the walls.

627. Q. Are king crabs good manure?

King Crab

A. Excellent; tens of thousands of bushels are used by farmers on the Manure.

South Atlantic waters. Their value, however, is only for one crop, as their fertilizing influence is very volatile.

628. Q. What is the difference between germination and vegetation? Germination.

A. Germination is the putting forth of a germ or sprout and the sustaining of it till the young plant makes connection with the ground: there germination ends and vegetation commences.

629. Q. Has moonlight any influence upon garden vegetables?

Moonlight.

A. No. Some plants of a very sensitive nature, as the Sensitive plant, awaken under moonlight, but no practical result has ever been noted.

630. Q. Is there much diversity between vegetable garden products in European Europe and the United States?

A. Quite marked. - In Europe the gardeners grow lots of things little cultivated here. For example, artichoke, cardoon, corn salad, chickory, cress, dandelion, swiss chard, scorzonera, sea kale, sorrel.

631. Q. What size cold frame must I have to hold twelve thousand Cold Frame. cabbage plants over Winter?

A. A frame made of boards sixteen feet long, and placed parallel at six feet distant, the ends being closed, will hold three thousand cabbage plants.

632. Q. Why do garden vegetables degenerate?

A. Because of careless selection. Esculents propagated from seed can tion.

be brought up to their previously highest quality if time be taken. They do not run out in the same manner as do some tree fruits propagated by grafts or buds, or the potato as propagated from the tubers, the eyes of which are really buds.

633. Q. Do plants perspire?

Perspiration

A. They do to a very large extent. It has been proven that a Sunflower of Plants. plant six feet high perspired in a day ten times as much as man.

634. Q. Why do some professional gardeners always want to buy old Cucnmber seeds of cucumber, meion and squash?

Seed.

A. Running plants from old seeds do not grow so vigorously as from new seeds. They are shorter jointed, while producing as many blossoms as long.jointed vines. They are also earlier in maturing and, being compact in growth, a greater number of hills can be planted to the acre.

635. What influence has the qualities of parents upon the progeny of Influence cross-bred plants?

of Parents. 
A. It is theorized that the male gives quality to the interior organism, the female to the external.

Peas. 636. Q. At what stage of development should table peas be picked from the vine to obtain them in the most palatable condition?

A. When about two-thirds developed, as then they are tender, luscious and altogether superior to qualities possessed when full grown.

Green Moss. 637. Q. How can I get rid of the green moss which grows in my lawn, especially in shady places?

A. Try three plans: top dress with salt, top dress with lime, spray the moss with Bordeaux mixture.

Extra Early 638. Q. What is the dividing line on Extra Early pea and a later class? Pea.

A. An Extra Early pea should arrive at picking condition at forty-two to forty-six days from germination. Any sort, whatever the name, later than that is not an Extra Early.

639. Q. How should corn be eaten?

Table Corn. A. Score the rows with a knife from end to end of the cob, and with a fork scrape down and off the edible portion, getting nothing but the soft interior, the shells of the grains being left behind.

Watering

Plants.

640. Q. Is watering garden vegetables in dry weather beneficial?

A. Sometimes, but often harmful. It is best done at night. If done during the day it excites the roots to action, the plants pumping up water and the leaves exhaling it to the dry atmosphere.

When the supply of water stops the roots and leaves are left in a state of collapse, sometimes worse than before.

Plant Dlscrimination.

641. Q. How is it that plants requiring distinct foods and producing widely different fruits or juices live upon the same soil ?

A. Partly because plants possess a power of food selection. The wheat plant for instance will absorb silex, and the pea growing alongside of it will not absorb any.

Potato Bug. 642. Q. The leaves from the stems of my potato crop have been all eaten off by the potato bug, but the tubers appear to be full size. Would the tubers have been larger if the leaves had not been destroyed?

A. Certainly; larger and more perfectly finished in development. Any condition unnatural is always a check to perfect growth and full maturity.

Sorghum. 643. Q. Which are the best varieties of sorghum for sugar making?

A. The Collier, Coleman, IIcLean and Folger. The last-named is the earliest maturing variety and the best all round in sugar-making qualities. The Collier is the hardiest and best for Northern latitudes.

Licorice. 644. Q. Can I grow licorice root in Georgia?

A. Yes; on low-lands it will grow freely. The dried roots in bales are worth $\$ 40$ a ton. The annual consumption in the United States is 35,000 ,000 pounds of the extract, largely used in confectionery and in tobacco.

Hotbeds. 645. Q. Should the soil used in hotbeds be changed frequently?

A. Yes; every year get new soil from a field known to be free from any disease. The old soil may be infested with parasites which may remain alive for many months, even though the earth may be frozen 
hard as iron during Winter. In the open garden old seed beds are often nurseries of disease.

646. Q. In growing onions here in Florida for the Northern market I Onions. have found difficulty in the fact they sometimes grow so large before the tops die down that they are not readily salable. Is there any way that I can cause the tops to die off when they are at the most desirable size?

A. Two courses are open to the experimenter: one to cut under the roots with a flat hoe or wide, flat plowshare, to arrest too great vitality; the other to break down the tops, pressing them flat with the hand or with some instrument wrapped in cloth or bagging, so as to be soft.

647. Q. What is a parasitic plant?

A. An order of plant which strikes roots into the substance of other Plants. plants and feeds on their juices. Molds and blights are examples of lowest organization of vegetable parasites. The mistletoe is of a higher order, forming large bunches often several feet in diameter.

648. Q. What is the cause of hollow stem in celery?

A. A bad stock. Years ago, before the selection of quality was so intense as now, a considerable percentage of every patch was always hollow, but now seldom 3 per cent. in the good varieties is found hollow. But some Italian celeries are entirely hollow.

649. Q. Which is the best method for a market gardener to follow: Sell-Selling ing his products through a commission merchant or direct sales to con-Vegetables. sumers?

A. If he is a large operator it would be impossible for him to sell to the consumers. A small operator can of course get better prices by taking to himself the profits of the middle men.

650. Q. What are cryptogamic germs?

Cryptogamic

A. The reproductive organs of flowerless plants. Some such plants Germs. become trees, but those injurious to cultivated garden vegetables are always microscopic in size and are known as garden fungi. They have neither leaves nor stems, their reproductive organs are situated in a mass of cellular substance.

651. Q. What sorts of vegetables best resist drought?

A. Drought-sustaining vegetables might be divided into two classes: first, those which develop deep roots, as carrots and parsnips, which are able to draw moisture from considerable depth, and secondly, those of thick, succulent leaves. An example of how thick-leaved plants can sustain drought while only surface-rooted is seen in the ordinary house leek and in common sand cactus.

652. Q. Will a crop of potatoes take more fertility out of a field than a soil crop of tomatoes?

A. Yes; potatoes may average 200 bushels to the acre of solid, starchy tubers, while the tomatoes, if they do average 400 bushels, are 95 per cent. water.

653. Q. How long will fungus germs remain in the soil after a dis. Fungus eased crop has been removed? 
A. After the crop is removed the fungus germs nearly always find weeds and plants of some other kind on the same land to feed upon, to perpetuate their species over the balance of the growing season, and through most Winters the germs will lie dormant, ready to attach themselves to some plant the next Spring.

Fungi.

654. Q. What are fungi?

A. A very low order of vegetation, a flowerless order, illustrated in our vegetable gardens by the mushroom and propagated by minute, spreading fronds.

Cabbage. 655. Q. If after I have set out my cabbage plants and they have rooted and commenced to grow, there comes a spell of cold weather which, althougli not enough to wilt the leaves, checks the growth for a period of several days, what would probably be the effect on their heading?

A. The check of transplanting young cabbage plants from the seed bed to the field seems to induce an inclination to form heads, but after the transplanted cabbages are well established any subsequent check from frost or severe drought seems to induce a disposition to go to seed. That inclination once established, the plants commence to show all sorts of variability of shape and character, sometimes not over half of the crop making good heads.

Sunburn. 656. Q. Can I use any preventive against sunburn of my watermelons?

A. When the vines are about half grown broadcast buckwheat, which by time the melons are ripe will protect them partially from the sun.

Beet.

657. Q. Where did the beet originate, or from whence did the first beet come?

A. It is a native of sandy seacoasts of the Mediterranean, Black and Caspian seas.

Onion. 658. Q. Is the origin of the onion known?

A. It is not ; but it certainly is one of the earliest of cultivated plantswell known to the Egyptians.

Web Worm. 659. Q. What shall I do to drive off an insect which is destroying my beets and mangels by eating the leaves and spinning a web on the top of the wreck?

A. The description would mark it as one of the web-worms, of which there are several. They do not confine themselves to beets, but will take anything in the way of garden truck. To kill them, spray with a solution of Paris green, one pound of the poison to 150 gallons of water, and three gallons of molasses to make it stick to the leaves.

French

660. Q. Why is not the artichoke cultivated as generally in the United Artichoke. States as in France?

A. Because our Winters are too severe, except in the cotton States, and because we are accustomed to better food. The artichoke is really of so little merit that it is not received with favor by Americans, even in localities where it can be successfully grown. The artichoke plant is a form of cardoon, which latter plant is cultivated for its bleached foot stalks 
and midribs. The cardoon does not produce edible heads, it being bred for its edible leaves, the artichoke for its edible flowers.

661. Q. There is a demand in my market for a Box radish of a deep red Radish. color. Is there such a radish, with a short top and of quiek growth, which I can use for the purpose? I want them to buneh with my White Box radish, and they must be of similar shape.

A. Landreths' Earliest is the one to use. It unites two marked qualities: First, an earliness in maturity for table, surpassing any other red sort ; secondly, a rich depth of claret or ruby color, unapproached by any other variety. In form it is turnip-shaped, in size and form similar to the Early Scarlet. The leaves, very short and small, fit it for forcing in glass house or frame, while its early maturity will astonish the cultivator.

662. Q. Can I improve my tomatoes by pruning the vines? If so, at Pruning what stage of growth should the pruning be done?

Tomatoes.

A. Pruning must be done with judgment, else the blooms will be cut off in too large numbers. Pruning, when well done, is advantageous, as it lets air and light into the vines, which otherwise might become a tangle in which no fruit could ripen.

663. $Q$. Is marl of much value as a fertilizer ?

A. That depends on the kind of marl. The best marl is Jersey green sand marl, by the use of which large districts in Jersey have been raised from poverty to affluence. On lands which fifty years ago not over twenty bushels of corn could be produced, the average crops now are fifty bushels. All kinds of shell fish deposits are called marl, but there is a great difference in value of various deposits.

664. Q. What is the manurial effect of large turnips plowed under, Turnips bulbs and leaves all turned down out of sight?

A. Very valuable; and a very quick and a very cheap means of enriching a field. The seed sown broadcast in August will develop a big crop by 1st November, ready for plowing down before the land is frozen. It is a system whieh should be largely practiced, as it is an efficient way of manuring the land and done at a season when there is little to do on a farm.

665. Q. What particular merit is there in a strap-leaf turnip? What Strap-lear does strap-leaf mean as applied to turnip? Turnips.

A. It means a leaf without indentures-a straight leaf like a rabbit's ear. There is no special merit in it-it simply indicates that the stock is a pedigree one. If it was not watched and culled it would soon cease to be a strap-leaf-would become a cut-leaf.

666. Q. Are the seeds of garden vegetables, when in eating condition, Maturity of sufficiently matured for sowing?

Seeds.

A. Those of watermelons, cantaloupes, pumpkins; hardly of anything else.

667. Q. What is the best pea to plant for a late crop, say in August? Peas. I have tried several sorts, but they always mildew.

A. Landreths' Extra Early is best, as it is the least subject to mildew 
at the season indicated, when nearly all other peas become so covered with the mildew as to be of little value.

Sugar Cane. 668. Q. From what country did the original sugar cane come?

A. From Southern Asia, India, Cochin-China, and Malaysia, whence it spread into Africa, and thence to America, reaching St. Doningo in 1520 and shortly afterwards Mexico and Brazil.

Clover. 669. Q. Where did the Crimson clover originally come from?

A. It is found wild in Northern Italy, in Sardinia, and in Algiers, in the valley of the Danube and in Macedonia.

Tomatoes.

670 . Q. I have very poor success in growing tomatoes in my garden. The soil is good and rich, and I can grow very large plants, but they do not'bear much fruit, and it is generally small and knotty, no matter what variety I plant. Can you explain the cause and remedy?

A. Possibly the plants go too much to leaf. Try pruning the roots by digging about them deeply; this will reduce the vigor of growth and perhaps cause blossoms to appear and set. Also trim the foliage to let in the light and air.

Fertilizers. 671. Q. How many brands of commercial fertilizers are there?

A. Probably 600 or 700 distinctly named sorts, all differing from each other in the proportion of contents of available plant food, some brands worth ten times the value of others, some not worth five dollars a ton.

Kainit. 672 . Q. Is kainit more valuable than common salt?

A. Yes; because it contains from 15 to 20 per cent. of potash, while common salt does not contain any. Potash is a fertilizer or plant foodsalt is not a food, only an alterative and insect driver. The kainit contains 60 to 70 per cent. of common salt in addition to the potash.

Sweet

Potato.

673. Q. Of what country is the sweet potato a native?

A. Not known positively, but presumed of MLexico or the West Indies, as it was cultivated in San Domingo in 1526. It differs from the white potato in its tubers being roots, while in the white potato the tubers are branches.

Pea. 674. Q. Where did the garden pea originate?

A. Probably in Asia, from the Caucasus to Persia. It has been found among the remains of the lake-dwellers of the bronze age in Switzerland.

Cow Feed. 675. Q. Which is the most nutritious for milch cows, green sugar corn or green sorghum?

A. Sorghum by all odds, as it contains from 8 to 12 per cent. of sugar.

winter Oats. 676. Q. Can I successfully grow Virginia Winter oats in Pennsylvania ?

A. Yod, if it be treated as a Spring oat, as the Winters are too severe in Pennsylvania to admit it to live as in Virginia. Sown in early Spring it will ripen three weeks later than ordinary Spring oats. It will be found far more productive than Spring oats and far heavier to the bushel, frequently going up to thirty-eight and forty pounds. As long back as 1869 it was grown as a Spring crop on Bloomsdale Farm, giving seventy bushels to the acre. 
677. Q. Why is it that two tomato patches, both grown from the same Tomatees. seed, develop fruit so distinct?

A. Frequently the case when the periods of sowing the seed or setting out the plants have been wide apart; the conditions of growth being very different, to say nothing of a possible difference in soil.

678. Q. How many days does it take from gernination for a good type Sorghum. of sorghum to reacl as high as 11 per cent. of sugar?

A. About 140 days, and about 145 days to reach 70 per cent. of purity.

679. Q. Is there any difference in period of maturity in a crop of corn, corn. one-third part of each grown respectively from grains taken from the butt, middle and end of ear?

A. No, not the first year; but the practice continued would result in a marked variability in forms of grains and value.

680. Q. Comparing the two systems of agricultural operations-that of Market ordinary farming, as the raising of grain, potatoes, hay, cattle and dairy-Gardening. ing, with truck farming, as in the raising of vegetables for market-which affords the greatest possibilities of profit, and which opens to the highly educated operator the widest tield for action and intelligent, if not scientific application?

A. The laborious efforts of the farmer producing wheat and other small grains, corn, potatoes, hay and dairy products, cannot be exceeded by the labors of any soil cultivator, but the mental details of such labors are insignificant compared with the operations of truck farming on a large area, as on the large vegetable farms near some of our large. cities. On such farms the ceaseless round of Spring, Midsummer and Winter crops of vegetables from the fields, and others from cold frames, hotbeds and hot-houses; the packing, shipping, correspondence; the details of appropriate fertilizers and special mechanical appliances; a large pay roll to be provided for every Saturday night, necessitates great responsibilities and demands technical and business qualifications such as are not looked for in the ordinary farmer. The operations of the two are so wide apart as not to be considered the same moment. One is humdrum, the other unceasing activity and demanding, if success is to be attained, qualities not required in a grain farmer, though his wheat fields may be ten times as big as the vegetable farm. No man wishing to turn to an agricultural pursuit is too intelligent or too scientific to adopt that of vegetable farming; for it is the most intense, the most interesting, the most technical, the most paying of all soil cultural operations. It is also the most uncertain, but this adds to the possibilities of profit as well as loss.

681. Q. In what part of the world was the garden bean first cultivated ? Bean.

A. In Western Asia. It was cultivated at Rome nearly two thousand years ago. It appears to have existed also in South America long before the Western Continent was known.

682. Q. Whence came the first cucumbers?

A. Not positively known, but thought to be from Cabal, in Northwest India. It has been cultivated in India for three thousand years. 
Cantaloupes. 683. Q. Cantaloupes, where did they originally come from?

A. It is believed they first came from Africa, but possibly they were natives of Asia as well. The Romans cultivated the cantaloupe and illustrated it in pictures now existing. The writer has obtained some very choice new sorts through the missionaries of Armenia.

Lettuce. 684 . Q. Where did lettuce originally come from?

A. The wild form still grows in the Canary Islands, Madeira, Algeria, and in Asia. The ancient Greeks and Romans cultivated it.

Spinach. $\quad 685$. Q. Where did spinach originate?

A. It was first cultivated in Western Asia. The seed originally was all prickly, the smooth-seeded being a perpetuation of a sport.

Watermelon. 686. Q. What is the native country of the watermelon?

A. Central Africa. Livingstone saw large districts covered with it.

Turnip. 687. Q. My Spring-sown turnips are stringy. What is the cause? I use the Red Top Globe. Is there any better sort for Spring sowing?

A. Yes; Early Flat Dutch, but it must be used when small, not bigger than a 50:cent piece, otherwise it is certain to get tough, fibrous and hot.

Cabbage

Worm.

688. Q. Will hot water kill the cabbage caterpillars without injuring the plants?

A. Hot water above $160^{\circ}$ will scald the plants, but below that will not hurt them. At any temperature below $160^{\circ}$ and above $1400^{\circ}$ the worms will be destroyed. It is an efficient remedy for use in small patches.

Lima Beans. 689. Q. I have experienced great difficulty in getting a stand of Lima beans; particularly in cold, wet seasons. Can I overcome this difficulty by soaking the beans in lard or any other moisture-resisting solution?

A. You probably plant too early. The Lima will not sprout in cold, wet soil, as it requires very favorable conditions as respects moderate moisture and warmed earth. Later plantings, when the soil is in favorable condition, will overtake early plantings and the vines be more healthy. If you must be early, start them under glass or in the house, and transplant when four inches high.

Puddling. 690. Q. When transplanting cabbage and tomatoes is it necessary to puddle the roots?

A. Not desirable unless they are to be shipped some distance. If to be planted at home, puddling is a mistake, as the mud cements around the roots and arrests their free action in the soil. Transplant only just before a rain or just after, and tightly fasten the plant in the soil.

Liquid

Manure.

691. Q. Do you advise liquid manure for application to garden vegetables?

A. Yes; applied between the plants, not on top of them, or it might scald. Only apply in the evening, as water excites the plants to actionthe roots to absorbing and pumping up and the leaves to evaporation. This during the middle of a hot day is injurious, but at night is beneficial.

Weeds. 692. Q. How can I keep my patlis free of grass and weeds?

A. Lime and salt will hold them in check, but not prevent them entirely. 
693. Q. Will burning straw on the surface of my garden kill weed Weed seeds. seeds and insects?

A. Only partially; as no heat which a surface-burning would make would heat the soil over two inches in depth. A deep plowing or digging will bring to the surface seeds and insects not injured by the heat.

694. Q. When should I manure my lawn?

A. Better spread stable manure in January, twenty-five cartloads to the Manure. acre, and rake off the remnant in March. Or, in February or March, broadcast to the acre 800 to 1000 pounds of superphosphate of lime and 200 to 300 pounds of nitrate of soda.

695. Q. What are the cheapest and quickest green crops I can grow in Green Crops. Delaware after September 1, to remain on the ground all Winter as a covering and to be plowed down in March?

A. Rye, living all Winter and forming a mat of roots and strong top growth. Indian corn, making a strong top growth by frost and then drying up-a good covering to the soil, preventing blowing. In Delaware, September 1 is too late to sow Scarlet clover to do any good by March, and late also for Cow peas which, when left to dry on the field, are very hard to plow under in Spring on account of the vines being like so many wires.

696. Q. Will it pay financially to suspend an electric light over a vege. Electric table forcing house to hasten the development of market vegetables? Light.

A. Not in all cases; for while some plants are benefited, others are retarded. The regetable most advanced by electric light is lettuce, which, it is estimated, is forced ahead quite a week by the use of electric light.

697. Q. Why do people in hot Southern climates, as the West and East Pungent Indies, Mexico and Brazil, consume so many hot vegetables, as peppers, Vegetables. leeks, and Spanish radishes?

A. As tonics to the system. In such countries the liver becomes torpid, the stomach weak, and foods flavored with peppers and other burning ingredients tone up the system to resist the evil effect of the climate.

698. Q. How is the percentage of sugar in regetables influenced by sugar in locations of latitude?

A. All vegetable garden products, as peas, beans, corn, parsnip, carrot, beets and melons, become more palatable as their cultivation approaches more nearly the northern limit of their successful growing. This may be attributed to the longer daylight in Summer of Northern latitudes. Good form and rich color do not always accompany palatability; quite the contrary, as some of the most exquisitely flavored apples and melons of Nova Scotia do not compare in appearance with those produced in local. ities much further South. The use of the electric light at night in gardens will some day, no doubt, become quite general where facilities for its use exist, as by its use can be obtained all the advantages, and more, afforded by the long twilight of a more Northern latitude.

699. Q. Adjoining me is a twenty-acre field which has been out of use Soil Recu- 
for five years-abandoned because of being poor soil. Is it likely to have improved by the rest during that period?

A. Most decidedly ; especially if in clover or grass, particularly clover ; but even an annual crop of weeds, not removed for five successive seasons, protecting the surface for five successive Winters, will have done it much good, the weeds collecting, but to a far less degree than clover, fertilizing constituents from the air, the deep-rooted ones drawing more from the soil below plow depth and their covering of the surface in a green form in Summer and dry, dead form in Winter promoting the accumulation of plant foods, especially potash.

Soil Fertility 700 . Q. Which are the most fertile, the farm lands of the United States and Farm Practice. or those of England?

A. The soils of this country, being newer, are naturally more fully charged with natural plant food, but here they are not cultivated under the intelligent and intense systems and processes of the English and Scotch, where the farmers are more thoroughly grounded in the principles of agriculture. This agricultural intelligence and the moister climate of England result in the growth of larger crops of potatoes, oats, wheat, barley, flax, and cattle roots. American farmers, while more intelligent upon the whole range of general subjects, more self-reliant and better able to meet unexpected difficulties, are, as a rule, only veneered with agricultural information. Just the same as the American people are veneered with scientific and literary information, or as our politicians are with statecraft, compared with the more thor. oughly educated men of Europe. Educated farmers, that is, men haring a fully practical and partly a scientific linowledge of agriculture and all its processes, are able, on comparatively worked-out soils, to reap a better return than the happy-go-lucky farmers of portions of our own country, even be they located on soil of virgin fertility. Farmers satisfied to drag day after day over the miserable public roads of this country, do not show much of those qualities possessed by the farmers of England; and their willingness to rest satisfied with the road conditions illustrates the condition of their farms and their systems of culture.

Coffee. $\quad$ \%01. Q. Can a good substitute for coffee be made from dandelion root?

A. Quite a good imitation; but better from chickory, and in greater quantity, as clickory produces a larger root. It is grown like carrots, plowed out after frost, washed, sliced and dried. By some preferred to coffee; is an excellent adulterant.

Systems 702. Q. Which is the best system of heating forcing houses?

of Ifenting. A. This is a question which has been under discussion for years, and probably will continue to be discussed for a long time. The arguments are so conclusive as put forth by the partisans of each system, that when listening to the advocates of one system no room seems to be left to doubt till the opposite side is heard. The writer, personally, favors hot water.

Wire Grass. 703. Q. My grass plot is completely taken possession of by wire grass. What sliall I do? 
A. Only one course is practical, and that is to dig up and remove the roots and soil, going to a depth of twelve inches Fill in the excavations with new earth free from wire grass.

704. Q. Are the methods of agriculture advancing as rapidly as the Methods of practice of other arts and professions?

A. No art is so favored. No art has so many newspapers published exclusively in its interests. Nearly every State of the Union has established agricultural experimental stations. Every scientific naturalist is working in the interest of agriculture. Thus there is being developed a theory of agriculture ; but theory and the results of practice to not always harmonize, as no control can be exercised over the degrees of rainfall, cold or heat, all of which have so direct an influence over the growth of plants, and little can be done to prevent the appearance of fungi and insect enemies; only palliative remedies when they do appear. Agricultural theories are very valuable, but they alone will not make a crop, as a ship-building designer plans an ocean racer.

705. Q. Why do cabbage heads sometimes burst open or split?

A. Because of an excess of moisture pumped up by the roots and so distending the tissues of the interior leaves as to burst the exterior ones. Cabbages while in a healthy, growing condition never burst, but only under the influences of a second growth.

706. Q. My melon vines, now half-grown, are dying at the root. Can Fungus. I do any thing to save them?

A. The trouble may be from sunburn or from underground grubs, but most probably it arises from a fungous attack destructive to the bark of stem and roots. If this be so the bark is brown and sluffing off. Nothing can be done to positively arrest the disease. Lime and sulphur may have a good effect.

707. Q. What effect has nitrate of soda upon garden vegetable crops, Nitrate of and can it be used to the exclusion of other fertilizers?

Soda.

A. Nitrate of soda is valuable for its nitrogen, which is an active stim. ulant. Especially valuable to leaf-producing plants. It is not a complete fertilizer, as plants want potash and phosphoric acid also. Most soils contain enough lime.

708. Q. What is the best receptacle I can use to exclude moisture from Keeping my garden seeds?

A. Tin boxes with screw tops or glass jars made air-tight by rubbers, as in preserving jars.

709. Q. What is the difference in the production of seed in the Russian Sunflower. sunflower and the old form?

A. The Russian is twice as productive, 2500 pounds of seed have been raised to the acre. The Russian produces but one flower to the stalk. The seed is valuable as food for poultry, hogs and cattle, and for making oil.

710 Q. When spraying my melon vines to kill the louse can I raise up Mrelon the vines so as to expose the under surface to the spray? 
Plant

Growth.

Tegetable

Sweetness.

Okra.

Egg Plant Fungus.

Lima Bean.

Mushrooms.
A. Yes, you can do it; but the disturbance to the vines would do as much harm as the insects. Melon vines, when over half-grown, are seriously injured by lifting. It is just here that the difficulty of spraying melons in the field comes in-it can seldom be done efficiently.

711. Q. At what period of the twenty-four hours do plants grow with the greatest rapidity?

A. Nost, but not all, grow fastest at night, as can be readily observed by marking the relative day and night growtl of the runners of watermelon, cantaloupe, squash, pumpkin; sometimes these will extend fifteen inclies between sunset and sunrise, while not lengthening over three inches during the day.

712. Q. Is there any difference in the degree of sweetness of watermelons grown in different latitudes?

A. Yes; all fruits, apples, pears, peaches, as they approach their northern limits of possible production, develop a degree of sweetness not possessed by others grown more southward. The watermelons of the Southern States are never as sweet as those grown in New Jersey.

713. Q. Arnong Okras which sort is the best?

A. Long Grcen Pod in every respect, and in fact no other sort is worth cultivating if this one can be had.

714. Q. Something is the matter with my egg plant bushes, they are all sickly and yellow and promise failure. Can I do anything to keep them?

A. There is not much chance of a good crop from the egg plant if the bushes once lose their vigor; indeed they should never be stunted or adverted in growth. If they are brown or black on the bark of the stems near the earth they are suffering from a fungous growth living upon the tissues of the bark, and nothing will stop it with certainty ; and even then a most serious injury will remain if the bark of the stalks has been half destroyed. Spray the stalks near the ground with Bordeaux mixture. Next year give your egg plant land nitrate of soda at the rate of 400 pounds to the acre; it may destroy the fungus and will give the plants increased vigor to resist the disease besides giving a better color to the fruit.

715. Q. Will a Lima bean, if planted with the eye upward sprout earlier than if planted with the eye downward?

A. They do best planted eyes down and not over one inch deep.

716. Q. Will you please give me the most simple and inexpensive method for cultivating mushrooms from the spawn?

A. There is no simple and easy method of doing it for the novice to follow. It is work which only an experienced liand can do with good chance of success. The work is rough enough in the handling and incorporation of horsc manure and good soil, but to do it well one must have had lessons from an expert. In no garden process is there such contra. dictory practice as in mushroom culture. For instance, one successful grower will gather dry droppings from horses, and still further dry them by spreading and frequent turning under cover. Another, equally succcssful as a grower, dispenses with all this trouble, taking stable dung 
fresh from the stalls, and mixing in a fourth part of good friable loam, piling it up for a week, then turniug it over, and, if fermenting too strongly, adding more loam.

A third grower takes his manure from an ordinary barnyard pile, and mixes in a fourth part of loam. Other growers will not use manure which has been fermenting, claiming that it will not produce mushrooms or a continuous erop. Another system is to take any good stable manure, and, removing sticks, stones, very long straw, or other coarse material, thoroughly mix and pile it in beds two feet high, thoroughly wet with water and stamp down. After a week or ten days, by which time it is quite hot, the pile is reworked and left for another ten days, then it is in condition to be made into beds of the proper form and seeded. Sometimes four to six weeks are taken in the preparation of the manure, a leading object with most cultivators being to have it half decomposed, completely mixed, but not wet.

Possibly the best system for the amateur to pursue is to prepare his manure pile under cover, as in a shed or cellar, making his pile one-fourth loam and three-fourths of the best stable manure he can get, horse dung predominating, which should be piled first, to allow it to lose its fiercest heat, the loam helping to solidify the mixture. At spawning time the heat in the beds should range from $60^{\circ}$ to $80^{\circ}$, never above $85^{\circ}$. The heat of a bed may be reduced by opening holes with a crowbar, forcing it down to the very bottom. One bushel of spawn broken into lumps of an inch in size is sufficient for 100 square feet of bed surface. The beds can be made on the floors of cellars, sheds, or under the benches of a greenhouse, or on raised benches like shelves in a closet.

717. Q. Why is the Lima bean so called?

A. It is supposed to have been first found at Lima. Certainly as a novelty it was introduced as from there. It may have been a native of Peru or an original production in its present form, or it may have been developed from some other bean as a consequence of some peculiar condition of climate in Peru. At the present day both white, black and spotted Limas are cultivated in that country.

718. Q. What was the color of the first variety of tomato cultivated ? First

A. It was red, and was first cultivated in Europe in 1596. The first Tomato. catalogue reference to the yellow tomato was by Landreth, in 1820 . The yellow sorts are generally of the best flavor.

719. Q. Do some plant bugs eat up other plant bugs?

A. Yes; the lice on cucumber vines and on melons are eaten up in Bugs. large numbers by a species of lady bug, and some species of thies eat the larvæ of the asparagus beetle. There are many insects which feed on each other.

720. Q. Is it true that the sugar corn grown in the State of Maine is Sugar Corn. sweeter than the same variety of corn grown in Virginia?

A. Undoubtedly; and a consequence of the long days of July and August. In Maine, the evening twilight lasts till 9 and 10 o'clock, and 
the morning twilight begins a little after $2 o^{\prime}$ clock. In fact it is only dark for four or five loours This resultsin the development of a degree of sugar far greater than possessed by any corn which can be grown in Virginia.

Radish.

Effect of Selection.

Cabbage Lice.

Hearing of Insects.

Eleotric Light.

Hybridiza tion.

Siglat of

Insects.

Aspliyxiation of Insects.

Grain

Insects.

721. Q. Which is the best Long White radish?

A. Lady-finger is three to four inches long, pure white, very brittle and early of maturity.

722. Q. Does careful selection over many years successively weaken the seeding qualities of vegetables?

A. Yes; all high-class vegetables, like animals, being by intense selection weakened in perpetuative powers.

723. Q. Is a field afflicted with cabbage lice upon a crop likely to be affected with lice the next year?

A. Yes, unless the Winter is severe, in which case not an insect may appear the succeeding Summer. If then they appear they can be kept in partial check by kerosene emulsion, the previous season demonstrating the necessity of being prepared to fight them immediately upon their first appearance.

724. Q. Do garden insects hear?

A. Yes, to a slight extent. The sound-producing insects all make their noises by abdominal joints, never through their mouths.

725. Q. What is the effect of electric light on growing plants?

A. Electric light seems to take to a degree the place of solar light, the plants continuing to decompose carbonic acid, to extract oxygen, and to perspire. A plant's health depends very much upon the quantity of carbonic acid decomposed ; consequently the electric light is valuable as extending, as it were, the hours of daylight.

726. Q. Will cabbage and turnip plants, blooming alongside of each other, hybridize?

A. There is little danger of hybridization occurring under natural conditions, even if a field of cabbage and one of turnips be immediately adjacent, but a hybridization will occur if an intense effort be made to effect it.

727. Q. Is the sight of insects well developed ?

A. No; very imperfectly. They are to a large extent guided in their movements by sense organs with which man has none to compare.

728. Q. Is there any gas which I can use to kill bugs on my garden plants?

A. You can use the vapor of bisulphide of carbon, provided you can procure air-tight vessels of paper, tin, or glass to completely cover the plants. Under these coverings, placed over the plants, introduce one tablespoonful of the liquid, which will evaporate and asphyxiate all insects within an hour. The breathing apparatus of insects pervades the whole body, and poisonous vapors penetrate simultaneously the entire system. Don't inhale the vapor, as it is a rank poison.

729. Q. What is the best course to adopt to kill insects in dry wheat, corn, or other grain or seed? 
A. Treatment with fumes of bisulphide of carbon. The grain, however, if to be used for milling, must be thoroughly aired, otherwise an offensive odor will remain. The work must be done in an air-tight room of a size corresponding to the amount of the seed to be treated. Four quarts of bisulphide is sufficient to treat four hundred bushels of grain at one application. The exposure to the fumes should be from ten to twenty hours. No fire should, in any case, be allowed near the room in which the treatment takes place, as the vapor is lighly explosive.

730. Q. How long should I wait for seed to sprout before condemning Unvital the seed as unvital?

Seed.

A. That depends on the age of the seed, the kind of seed, the time of sowing, the condition of the soil when sown, and the subsequent conditions of atmosphere, and how shallow or how deeply put in. Any one of these conditions being very unfuvorable might prevent germination of perfectly vital seed. Some people are entirely too quick to jump at a conclusion that because seed don't come up that it is unvital. They know too much, based on a very small experience.

731. Q. Why do I have so much trouble in securing a good stand of Parsnips. parsnips ?

A. The seed is always very light and slow to germinate, even under the most favorable conditions. When the soil is dry, and still worse, baked by the sun, the seed is especially slow to sprout; but, left alone, it will generally come in time. Many crops are given up by the planters entirely too soon-they should have patience.

732. Q. Why are New Jersey cantaloupes sweeter than those grown Jersey farther South?

Cantaloupes.

A. A section two hundred or three hundred miles farther north of a more southern section enjoys a longer daylight and twilight during July and August, just as in extreme Northern regions, approaching the North pole, the sun does not set, but shines continuously the twenty-four hours. This condition of extended daylight is farorable to the development of sugar. Visitors to Canada in August never fail to praise the Montreal melons for their delicious flavor. The seed, taken from the melons and planted in a more southern locality, will not produce melons equal to the originals; and generally Northern seed is not all vital, due to imperfect pollination. New Jersey cantaloupes unite all the good qualities of form, size, color and flavor. Jersey sands seem to be the home of the cantaloupe.

733. Q. When does the pollination of squash, melon, cucumber, and Pollination. flowers of all other vine plants of like character take place?

A. Nearly always early in the morning, and generally through the agency of insects. Some time may elapse during the passage through the style to the ovules, but it gets there finally. The female flower of the cucurbit family generally produces an embryo fruit or ovary before fecundation. Their fruit, if not fecundated, either produce unvital seed or most gencrally drop off. Vine crops are retarded in pollination when frequent 
foggy mornings occur during the period of blooming, the water wetting the pollen and the succeeding hot sun burning it.

Keeping Sugar Corn.
Underground Grubs.

Classes of Insects.

Insects in Glass House.

\section{Cabbage} Heading.

Vital Melon Seeds. veloped?

734. Q. I buy my Sugar corn seed always about January 1, and when I come to unpack it in February $I$ often notice a musty smell about it. How can I plevent this?

A. Sugar corn is very full of oil, which becomes rancid if the seed is not dried thoroughly. Received in January, or even in February, it should be immediately taken out of the original packages, bags or boxes, and spread out, not over four inches deep, on a cool floor. If this precaution is not taken there may be much complaint from planters that the vitality proved to be low, when its failure to sprout was entirely the fault of the merchant or dealer.

735. Q. What are the various articles which I can use to kill grubs and worms under the surface of the soil ?

A. Kerosene emulsion, kainit, bisulphide of carbon, all are effective.

736. Q. How many classes of insects has a gardener to fight?

A. 1. Those known as external feeders, comprehending all which bite and eat vegetable matter.

2. Those known as sap-suckers, which puncture vegetable tissues and extract the juices.

3. Those known as internal feeders, which exist within the stems of plants.

4. Subterranean insects, which eat vegetable matter beneath the surface.

5. Those which destroy the dry seeds, either from the exterior or in. terior.

737. Q. How can I best kill lice and other insects on melon plants in my glass house?

A. Fumigate with tobacco twice a week. Don't wait till damage is done, but smoke before the lice curl the leaves. Mites and mealy-bugs can be knocked off the vines by a hard stream of water. Bisulphide of carbon, when it can be applied to plants under a bell glass, is very effective, but the chemical is explosive and poisonous. Sulphur fumes are an invaluable agent in destroying mildew and red spider. There is no excuse for failure to kill insects inside of a glass house.

738. Q. Why do cabbage plants sometimes fail to head, though fully old enough and planted out early enough?

A. Because of a want of nutrition. Cabbage plants sufficiently fed, and given time enough, will always head, provided the variety be of a heading sort.

739. Q. Is a melon seed from a fruit in edible condition perfectly de-

A. Quite sufficiently developed. Allowed to remain in the fruit till it decayed, the seed would probably more fully fill out and become heavier, and retain its vitality for a year or two longer.

Cabbage

Cice.
740. Q. Is there a reliable remedy which can be used to rid cabbage plants of lice? 
A. Kerosene emulsion is probably the best-nothing is a positive cure.

741. Q. What is the effect of the successive use for years of hut one Commercial kind of commercial fertilizer?

Fertilizers.

A. The land will gradually decrease in productive capacity. $\Lambda \mathrm{ny}$, or all, commercial fertilizers used for years successively without stable manure or green crops plowed under will in the end be disappointing. 742. Q. My lettuce, which promised a big profit, nearly all decayed Lettuce before maturity. What is the cause?

A. No doubt a fungus, for which there is no effective remedy, the lettuce leaves being too delicate to resist treatment. The only remedy is to . avoid that field the next year.

743. Q. Which is the most productive third early pea of excellent Bloomsdale quality for private or market garden?

Pea.

A. The Bloomsdale pea is phenomenally productive and in eating qualities surpassed only by the Landreths' Extra Early, having its size, color, flavor and general appearance when cooked. It matures its pods for table sixty-five days from germination and continues to bear for ten days a profusion of pods containing nine to ten peas in a pod.

744. Q. Of tomatoes now in general cultivation which is the most Best showy as respects color, size and shape?

Tomatoes.

A. The Stone ; but several of the Bloomsdale Hybrids are superior to it in productiveness, earliness and shape.

745. Q. What vegetables are there which can be grown in this country Onusual and which are really worthy of general culture, but which are not so cul- Vegetables. tivated?

A. Swiss Chard beet, the thick, marrow-like ribs of the leaves of which are eaten when prepared like stewed celery. Broccoli, which sometimes succeeds where cauliflower fails. Brussels sprouts, which if not destroyed by lice will grow to perfection wherever the calbbage will flourish. Dandelion, the leaves furnishing an excellent salad. Sorrel, the long-leaved, very popular in France and Germany as a salad. Cos lettuce, a form which should be better known.

746. Q. How many kinds of insects are there feeding upon garden Number of vegetables, and how many sorts of rusts are there which effect a lodg. Insects and ment upon garden vegetables?

Molds.

A. Vegetables, like men, are subject to so many diseases that it is a wonder they cver arrive at maturity. To enumerate the number of insects would be difficult, especially as the number is always changed by the apparent disappearance of some and the uncxpected appearance of others. So also with fungi, there being increase and diminution by conditions of moisture, heat, and previous condition of soil.

747. Q. What is the most intensive branch of commercial vegetable Intensive growing ?

A. Winter culture under glass as specially applied to the growing of tomatoes, cantaloupes, mushrooms, cucumbers and cauliflowers. 
Ornamental Flowers.

Bordeaux Mixture.

\section{Bordeaux}

Mixture and Paris Green.

748. Q. Why cannot I succeed in Virginia in growing ornamental flowers with the same success as I did in England?

A. In England the climate is damp, while in Virginia it is dry, the annual rainfall in Virginia not being over one-third of as many inches of water. Some seasons annual and biennial flowers do admirably in the vicinity of Philadelphia, other years they are miserable failures, all depending upon the climatic eonditions in June, July and August.

749. Q. Will the repeated application of Bordeaux mixture poison the soil?

A. No records of any injury, the copper sulphate being neutralized by the lime.

750. Q. Can Bordeaux mixture, a fungicide, be mixed with an insecticide, and both applied at once?

A. Yes; Paris green or London purple can be mixed with Bordeaux mixture-one pound of the arsenite to $\mathbf{1 0 0}$ gallons of Bordeaux-and used to good effect. As the mixture is very tenacious, care must be observed not to apply it immediately before the ripening of fruit, as rain will not entirely wash off the application, and some poison might remain on the fruit or vegetable.

Poisoning by 751. Q. Is there danger of poisoning members of the human family Bordeaux through fruits or vegetables which have been sprayed by Bordeaux Mixture.

History of Bordeaux Mixture.

Time to Drill. mixture?

A. None whatever, so far as any records go ; but it is best to avoid risks, and as maturation of fruits or vegetables approach to decrease to one-half the strength of the solution.

752. Q. What is Bordeaux mixture? When was it introduced and what is it used for?

A. It was introduced among the grape growers of Bordeaux, France, about 1878 , but not brought into prominent notice until six to seven years later, when it was largely used in the treatment of black rot and downy mildew. This fungicide is now in more general use in the United States than in any other part of the world because American cultivators as a mass are more progressive men than foreigners. Much confusion exists as to its preparation. The general standard now may be taken as six pounds of good copper sulphate, free from iron or zinc, four pounds of strong, fresh quicklime, twenty-two gallons of water. This mixture, which may be diluted by the admixture of two or three parts more of water, is used for spraying fruit trees, and all garden productions for the destruction of any vegetable fungous growth.

753. Q. When drilling garden seeds is it best to drill before or after a rain?

A. If the drilling is done before rain the seed may lay without sprouting for days or even weeks, and the land baked hard as a brick, or if the seed sprouts from a little moisture it may subsequently die for want of more moisture. If rain quickly follows the drilling the germinating conditions may be all right, but the seed may be washed out of the drills or 
may be covered deeply by flooding and the stand be unsatisfactory. On the other hand, drilling after a rain is best, because germination follows immediately and uniformly with little risk of a setback to the crop.

754. Q. Is it a saving in labor and time to have long or short fields on Plowing and a farm? Cultivating.

A. It is decidedly economical in time to have a farm laid out in long fields, but it is seldom appreciated. On an acre field of ninety yards in length the time consumed in turning a plow and team on headlands is over three hours out of a day of ten hours, but on a field 300 yards long the time consumed is but one hour.

755. Q. How far does a plowman walk in turning over an acre of ground? Plowman.

A. If his furrow slices be nine inches wide he has to walk over seven miles to the acre.

756. Q. Do garden vegetables possess any quality like sensation?

A. Most certainly; their vital force in many instances being quite animal ; and, more than that, they sometimes seem to possess intellect. They collapse under chloroform; they perish under many poisons which destroy animal life; they possess a circulation, which sometimes can be seen, their pollen unerringly performs its functions. In cases of vegetable irritability there are many plants, notably aquatic, which act more curiously than the Sensitive plant; indeed, so briskly locomotive as to make it difficult to determine whether vegetable or animal. In the case of the so-called meat-eating plants some of the flowers display extreme irritability when meat is brought near to them, while they are entirely passive upon the approach of all other objects.

757. Q. Are not yellow ruta bagas and yellow carrots more nutritious White and than white ruta bagas and white carrots?

A. As a rule, vegetables of deep colors are considered richer than those

without color. But this is probably a fiction; the most sugary beets used in Europe for sugar-making are white. The sweetest of all table beets, the Bassano, is nearly white.

758. Q. How can I kill the last crop of potato bugs, so that I may par-Potato Bug. tially rid my fields of the pest for next year?

A. After the potato crop is harvested take a portion of the small, unsalable tubers, and chop them up in halves and quarters and dust them well with Paris green. Broadcast these poisoned pieces over the potato field and they will soon be covered with bugs, all of whom will be killed.

759. Q. How can I protect my watermelon patch from crows, which Crows. plug the fruit?

A. Dissolve a quarter ounce of strychnine in four quarts of water and into the solution put one-half bushel of corn. Let it soak for ten hours. Spread the soaked corn over bare spots in the melon field and the crows will not come back for a second dose.

760. Q. Is there such a thing as a rust-proof Wax bean, and will not the Rust-proof so-called Rust-proof Wax bean rust under certain conditions? If so, what Wax Bean. is the nature of such conditions? 
A. All beans will rust under conditions of damp atmosphere. The disease, as it is called, is a fungous growth, which may be partially routed by the application of Bordeaux mixture, but it must not be applied to marketable beans

RadishPoor Crop.

Fungicide.

Agricultural Discovery.

Cauliflower.

Cantaloupes.

761. Q. I have a patch of radish growing from a remnant of your seed left over from last year, when the style of the roots were perfect, but this year the same lot of seed produces roots of all shapes.

A. This will sometimes happen, and is a consequence of field conditions or local influence ; each case has its own explanation. We cannot be held responsible for these variabilities.

762. Q. What is the best fungicide?

A. Bordeaux mixture, by all odds. Any one can make it and apply it. When a pump or syringe cannot be had, it can be dashed on the plants with a broom dipped repeatedly in a bucket.

\section{Q. What is the latest agricultural discovery?}

A. That the roots of the leguminous family develop corpuscles which absorb nitrogen from the air and thus enrich the soil for the feeding of succeeding crops. The effect of leguminous plants is not new, but the manner of their storage of nitrogen is a new discovery, first announced in 1886 by Professor Hollriegel.

Green Crops. 764. Q. Where I came from, in Germany, the soil of whole districts has been raised from poverty to fertility by plowing under green crops of lupines. Why is it not done in parts of Virginia?

A. Because the lupine will not thrive in Virginia for want of sufficient moisture in the air and soil. Try cow peas, which will do perfectly well.

765. Q. Is not cauliflower an uncertain crop?

A. Sometimes, but not always; for localities are known where it is uniformly a success-so much so that three and four fine crops cau be successively grown on the same field, while, curious to say, other fields not far distant and apparently of same character and quality prove to be not adapted to the crop. A salt atmosphere is particularly favorable to the perfection of cauliflower, but in itself is no assurance of success; favorable soil is an equal necessity. These two are not all, for supplemental to them must be a moist, cool atmosphere during the heading season. It is easy to grow cauliflower leaves-they will grow on any cabbage soil-but to produce good heads of cauliflowers more is required than pertains to the most famous cabbage-growing sections.

766. Q. Why are more sports found in a poor crop of cantaloupes or watermelons than in a good crop, both good and poor patches grown from seed out of the same package?

A. The seed being the same, the unfarorable circumstances producing the poor crop, whicl circumstances may have been too early or too late planting, want of moisture, want of fertility, insect attack or fungous growth, are the causes of a variation of uneven growth of vine, unequal development of fruit, all resulting in a variation of shape, flavor, or other usual or normal qualities. 
767. Q. When potatoes of different sorts are grown side by side, will Potato. the mixing or hybridization between the flowers of distinct sorts produce any appreciable change in the tubers?

A. No effect whatever, the seed in the seed-balls only being affected. Every potato is like a graft or bud from the original parent, and pollina. tion don't affect it in the least.

768. Q. Does a rank growth of vegetables induce a tendency in them Qualities of to take on new qualities?

Vegetables.

A. Yes; it does. The most intense development of qualities of approved color, form and flavor are best perpetuated in half-starved plants. On the contrary, a luxurious growth causes plants to sport in all directions, to run off at tangents, generally to the bad.

769. Q. I find in my lettuce seed some sort of an insect which spins a Lettuce web, causing the seed to adhere in lumps. Why did you send me unclean Insect. seed?

A. Nearly all oily seeds stored under conditions favorable to the development of eggs will hatch out insects. Many of these insects will spin webs or otherwise cause the seed to adhere in lumps. Nearly every seed has its insect affinity, which deposits eggs in the immature seed while standing in the field. The grubs from these eggs will hatch out under conditions favorable. The pea bug and the bean weevil are familiar examples. Lettuce seed, cabbage and turnip and vine seed all have their insect enemies.

770. Q. Why is it that such seeds as I have to keep for over a few Humidity months in my store here at Summerville, Ala., lose so much of their Affecting vitality? Seeds.

A. Because of the moisture in your atmosphere swelling the germs, to be afterwards dried by change of air and successively swollen and dried several times, so that vitality is seriously weakened. This condition applies in various degrees to all those sections of the Gulf States where forest moss luxuriates. Where the moss flourishes the most vigorously the conditions stimulating its growth are intensely destructive to seed vitality, all this the result of moisture in the air blown in from the warm, damp waters of the Gulf of Mexico.

771. Q. Among the Yankees, Winter squashes have a great celebrity, Winter and $I$ have eaten them in Boston with relish, but down here in Carolina Squash. am disappointed. Why is it ?

A. Altogether climatic. With you in the South they grow too fast and become coarse, stringy, tough and are deficient in sugar. They do best in the North.

772. Q. Will corn grown from grain taken from points and butts of ears Corn. degenerate?

A. Not in one year; but if such selection be continued for two years or more a change would be very noticeable. The practice even for one year is not to be encouraged.

773. Q. Which is the standard variety of late cabbage? 
A. Landreths' Large Late Flat Dutch is the unit of comparison by which all other late sorts are graded. None exceed it and few equal it. Variations of this cabbage live been given all sorts of names, but new names make it no better, while the selection is often made by men who do not know what constitutes a good cabbage.

Phonograph Pea.

Squash vine. 775. Q. What is the matter with my Hubbard squash vines? They are nearly all dying.

A. No doubt they are dying at the root, either from an insect attack or from a fungus, probably now too far gone to do anything to save them. Another year, when the plants are just beginning to run, treat them at the root, both with Bordeaux mixture and an insecticide.

Clover. 776. Q. Is it advantageous to sow ordinary Red clover with Crimson clover, that the Crimson may have a succession?

A. No ; the Crimson to be any good should form a dense mass the first Spring, and such a growth would smother out the much less developed plants of the common Red clover.

Cultivation During Drouglit.

Teeds on Law1.

Cncumber ibetle.

Cabiage for Elorida.
77\%. Q. Will frequent horse cultivation of a crop in dry weather tend to provide the crop with more moisture at the root than if left without cultivation?

A. Yes; the soil kept loose absorbs more moisture than it loses. Keep the horse cultivator going even if it kills a few plants, the others will be benefited to more than compensate for those injured by the culture.

778. Q. For twenty years weekly, during Summer, I have cut my lawn with a horse lawn mower and no weed has gone to seed or risen over two inches in height. This Summer I was in Europe, and upon my return I find my once beautiful grass a wilderness of all sorts of weeds. How is it?

A. This is one of the conumdrums of horticulture. It is always so with any field not kept in control, be it grass or fallow. The seeds have been there all the time, a part sprouting every year, but formerly the young weed plants were cut off soon after germination. On this occasion they were not so cut off, but attained full size, for weeds nearly always grow quickly.

779. Q. Does the little, striped cucumber beetle come out of the land, or do the seeds of the cucumber contain the beetle?

A. No, not out of the seed, but from the earth. Lime and salt, when not applied in too large a dose, are beneficial. Kainit is good, so is nitrate of soda. Don't overdo the medicine.

780. Q. Which is the best cabbage for Florida and the Gulf States, for July planting?

A. Reedland Early Drumhead, as it stancls the sun without burning or wilting, and las proved itself in every way adapted to the prevailing conditions of the Gulf atmosphere. 
781. Q. What is the best spraying apparatus?

A. We decline to take sides on this question. Many are the best, if the Apparatus. manufacturers are to be believed. That one is good which throws the liquid to a distance and with force and well subdivided. Spraying to do any good must not be done in a liurry, but done efficiently. It must be done at the right time, and the mixture correctly prepared and continually kept in agitation, that the parts may be kept in a perfect uniformity of suspension or admixture. The aim in spraying should be to cover every leaf with minute particles of the fungicide or insecticide, dropped on them so lightly as to remain and dry there, leaving the destructive principle behind. If put on in large drops it runs off and no practical results are attained.

782. Q. What is celery blight?

A. Different developments of fungi, generally contracted in the seed Blight. bed; consequently the seed beds should be sprayed with Bordeaux mixture and the field plants also, but not when approaching maturity, as that might be dangerous to consumers. It is difficult when the plants are large to treat them, as the blight or rot affects the centre of the plants. Less blight occurs when the celery is bleached between boards than when bleached by banking in earth.

783. Q. What is the disease or rust occurring on beans and known as Bean anthracnose?

\section{Anthracnose.}

A. It is a parasitic fungus attacking any part of the tissues of the root, stem, leaves or pods of either bush or pole beans. It appears in the forms of ulcers, or sunken black and rusty spots, and is very contagious, a diseased pod or leaf quickly inoculating another. For instance, a basket of green pods, some diseased, others healthy, may in twenty-four hours, by contagion, all become diseased during the period of transportation. The disease can be transferred from place to place by a hoe or other im. plement. Wet weather is particularly favorable to the spread of this disease. Soaking the seed beans in fungicides fails to do much good-better results are attained by a weak solution of Bordeaux mixture applied to the plants every ten days. Too much Bordeaux mixture dwarfs the bean plants, or any other plant.

784. Q. Is the anthracnose the only disease affecting beans?

$\Lambda$. No; there are several others, prominent among which is a bacterial disease known as the bean blight, nuder which the foliage becomes yellow, spotted and soon dead. Another, known as the bean rust, is the outward sign of an attack of fungi which develops inside of the tissues of the leaf, and breaks out in the form of a discharge of rusty spores all capable of reproduction. Bordeaux mixture is the most satisfactory remedy to keep these in check. It will not stop them from originating. The scientific men have accomplished much in ferreting out the character of these diseases and are diligently endeavoring to find preventives, but nothing yet has been found which might be termed dead sure to stop 
these bean diseases. Of course the fungi can be killed, and so can the bean plants.

Soiling. $\quad$ 785. Q. What is meant by soiling?

A. Feeding cattle, kept up in stalls or pens, food consisting of green stuff, as rye grass, millet or corn, taken off in sections from a field planted for the purpose. To cut for soiling the crop is always grown very thickly and it is fed when in full vigor of growth. At first care must be exercised or horses or cattle will overfeed.

Cantaloupe. 786. Q. Which is the superior in quality of cantaloupes, those of green or yellow flesh?

A. As a rule green-fleshed are the best in texture and best in flavor. Yellow-fleshed sorts are generally tough and meaty-the green flesh being more crystalline.

Cos Lettuce. 787. Q. Is Cos lettuce treated the same as other sorts of lettuce?

A. No; the erect leaves must be tied up with string, straw or grass. Thus treated the interior leaves become blanched to snowy whiteness and become brittle as glass. To those liking an absolutely pure, whiteleaved lettuce the Cos has no superior.

Watermelon. 788. Q. What are the indications of ripeness in a watermelon?

A. The spiral, wirelike tendril at the stem end of the melon is brown, the white bottom on the earth side of the melon has become woody, and upon gently thumping with the back of the finger nail various melons, the sound will be found in unripe ones to be clear and bell-like, seeming to run down and through the melons, while in ripe ones the sound is dull, heary and is not transmitted through the melon, because of a change in the character of the interior. By the tapping system an expert can distinguish ripe from unripe melons in an instant.

Long Green 789. Q. Are there two sorts of Long Green cucumbers?

Cucumbers. A. Yes; the Long Green as ordinarily sold and the Long Green Turkey. The first is like an Early Frame, the second is slimmer and twice the length of Frame, sometimes twenty inches. The Turkey is a remarkably good sort, fine for pickling green, and wheu larger, very showy as a slicing sort.

790. Q. Which is the earliest long cucumber?

Earliest

A. The Landreths' First. Not only early as the very short sorts, but

Cucumber. exceedingly long. Not so long as a Long Green Turkey, but two weeks earlier than the Turkey and several days earlier than Spine or Frame.

Lettuce 791 . Q. Is it necessary to transplant lettuce to incline it to head?

Trans-

planting.

A. Not absolutely necessary, but of decided advantage, as the temporary check to vitality and the deeper setting in the earth all conduce to the development of a heading tendency.

Ruta Bagas. 792. Q. There are a great many ruta bagas offered to planters, which or sort is the best?

Swedes.

A. None can be compared to the Bloomsdale Swede. It is the earliest, roundest, largest, smoothest, best colored and most showy. Without any 
neck, with few root fibres, and the best Winter keeper of all forms of Ruta Bagas.

793. Q. I only want to cultivate one sort of cauliflower. Which varl-Caulitower. ety do you recommend?

A. The Snowball. Early and reliable in a cauliflower country. If you are not in such a locality it is not worth while to try and grow them in the open field. Of course they can be grown under glass anywhere under proper conditions of treatment.

794. Q. A portion of my lawn, which I did not keep mowed down, is Sorrel. full of sorrel. How can I get rid of it?

A. Broadcast air-slacked lime at the rate of fifty bushels to the acrethe land is sour-that will sweeten it.

795. Q. When drilling ruta baga seed, radish, spinach and other small Drilling. seeds, should not the man pushing the drill straddle the row so as not to tramp on the fresbly placed seed?

A. No; let him walk right on top of the drill mark. If he had four feet he would not do any injury. Where he tramps the seed will be up first if the weather is dry. This indicates how advantageous rolling is, provided the ground be not wet and provided there be no rain for one or two days.

796. Q. Which are the most showy varieties of cantaloupes for exhibi- Cantaloupes, tion purposes?

Showy Sorts.

A. The Large White French and the Large Black Paris. Tested in the trial grounds of the Rural New Yorker, they were pronounced in September, 1894, the most remarkable ever seen for size, general appearance, and quality, and most highly recommended to the public.

797. Q. Which is the largest white flat onion?

A. The Bloomsdale Pearl. Early, large, flat-very mild.

Onion.

798. Q. Which spinach will stand the longest in the garden without Spinach. shooting to seed?

A. The Ever Ready ; the leaves very thick, dark and sturdy, and only shooting to seed long after other sorts have completely dried up.

799. Q. Among onions, which is the earliest to make sets?

A. The Bermuda Red.

800. Q. My turnip field, which two days ago was fine, the plants being Turnip Fly. one inch high and thick in the rows, is to-day all eaten up by a black bug. What can I do?

A. Nothing but drill another field, it may be eaten up also-you will have to run that risk. The turnip fly, a jumping beetle, is at times ex. ceedingly destructive, eating the plants when from one-tenth to one inch high. After the plants develop the rough leaf they are comparatively safe. There is no remedy against this insect, as it often destroys the crop the day after hatching out, generally destroying it before the insect is known to be present at all.

801. Q. Is il best to spread and turn under long-strawed barnyard Barnyard manure in the Autumn, or pile it for further decomposition and for appli. Manure. cation in the Spring? 
A. Better pile it for further fermentation, provided it be piled and attended to so as not to burn or fire-fang, otherwise nearly all the valuable properties will leave it. If this attention cannot be given it better spread it and plow under in the Fall.

Peat.

Cantaloupe.

Forcing

Lettuces.

Fungicides and

Insecticides.

Cabbage

for Antumn.

Treeds on Tennis Court.

Weeds

in General. 802. Q. Is peat valuable as a fertilizer?

A. Yes, to a small extent; but principally as an alterative, and as an aerator to heavier or lighter soils. It pays for digging and hauling on one's own farm at odd times, but it has no commercial value.

803. Q. What do you consider one of the best citrons or muskmelons?

A. The Annie Arundel cantaloupe or muskmelon-good size, oval to pointed, well ribbed, green in flesh and of exquisite flavor; a good shipper. 804. Q. Name one of the best forcing lettuces.

A. The New York Experimental Station has two or three times announced that Landreths' Forcing was one of the best. The Virginia Solid Header is an excellent one.

805. Q. Can I plant my garden crops with confidence that, through the practical application of scientifically compounded fungicides and insecticides, I will be assured of my ability to keep the plants healthy ?

A. No; the treatment of plant diseases is met with at every turn by unexpected checks and unlooked-for changes in conditions. The treatment against insects and fungi is at the most palliative. The scientists are always most sanguine, but the practical farmer and gardener know well how often their treatments fail to attain the results which they were so certain of securing

806. Q. What is the best variety of cabbage for Autumn sowing?

A. For early Fall the Reedland Early Drumbead. For Winter sow Market Gardeners' Large Late Flat Dutch.

807. Q. I have a dirt lawn tennis court in which weeds are continually growing, and write to inquire how to prevent them from appearing ?

A. Spread a balf bushel of salt on the court and two bushels of airslacked lime. These applications will destroy weed seeds upon germinating and drive off worms, grubs and other insects.

808. Q. Where do the weeds come from?

A. From your own carelessness or that of your predecessors. Not onequarter of the weed seeds which ripen upon a cultivated field germinate the next year. Those which do, are mostly killed, but those seeds which do not germinate just lay in the ground awaiting favorable opportunity. To these seeds laying dormant are every year added a fresh supply, so that your soil_-all soils-are thoroughly stocked with seeds ready to spring into life under favorable conditions. To many seeds these conditions may not come for years. To some not for twenty years, but when the conditions do present themselves the weeds come up with the certainty of taxes.

Good Roads. 809. Q. Is the so-called good roads agitation, which will increase the taxes of farmers, in their interest?

A. Farmers as a rule are blind as bats. They are so afraid of taxation as to stand in the way of their own interests. Farmers, rather than 
repair a mud hole at the county's expense, still more at their own, will drag along through it for weeks. Not only one hole but a score, if, indeed, the whole length of a frequently traveled road is not in a wretched condition-dragging along day by day, wrenching their wagons, breaking their harness, injuring their horses and souring their tempers. They are afraid of doing something which may add to the comfort of some one who did not contribute to the improvement. It is this penny-wise and poundfoolish policy which prevents farming from being as profitable as it should be, and which brings ridicule so much upon the farming community.

810. Q. What is the best shipping watermelon?

A. If to withstand rough usage on railroads the Kolb Gem, but it is Shipper. the poorest in quality of any to be found in market. The taste of the whole melon-loving community has been debased by the use of these miserable Kolb Gems. The best watermelon, all things considered, is Arkansas Traveler, color, black green, rind very tough and woody, but extremely thin, flesh deep scarlet, and edible to within half an inch of the outside, interior always solid crystalline, exceedingly juicy, and sugary to the most remarkable degree, and yet the rind is hard as wood, fitting it to bear long transportation and rough usage.

811. Q. I am a canner of peas and find it difficult to put up a perfectly Peas unniform grade, in fact I am surprised to find so great a difference in the for Canning. same variety of peas?

A. The fault is probably your own. You possibly do not buy the green pods in the same condition one time with another; or perhaps you buy too many at a time, and the last of the lot before you get to it is hard and off-color. Don't always blame the seedsman-look a little at home.

812. Q. I want to put down a two acre lot in grass for my cows. Pasture Which kind or variety of grass is the quickest and most permanent? Grass.

A. Blue grass is not quick, but by all odds it is the best. On a limestone soil it will remain good for fifty years.

813. Q. What is the best shipping cantaloupe?

A. Strongly webbed or netted sorts will stand abrasion during transportation. This quality, however, is no measure of flavor. But both for shipping and eating, none are superior to Anne Aruudel.

814. Q. I have just dug my potatoes and they are covered with scabs. Potato Scab. What is the cause?

A. The injury may be from several causes: the tubers at one period of their growth may have been overcharged with juice which burst the skin, and nature endeavoring to heal the wounds produced scars or the scabs may be the result of a fungous growth upon the skin. This could have been diminished if not nearly all prevented by giving the planting stock, after cutting, a bath in corrosive sublimate.

815. Q. What are the best varieties of lettuce for Autumn use?

A. Bloomsdale Early Summer, Virginia Solid Header, and Reliable.

816. Q. What do the commercial manure men mean by available phos- Phosphmic phoric acid?

Acid. 
Phosploric Acid.

Tomatoes Sunburned.

Imported Cabbage.

Onions

Staggy.

Rye, Winter or Spring?

Wood Ashes.
A. They classify phosphoric acid in three forms : 1. Soluble. 2. The Reverted, slightly soluble. 3. The Insoluble. 'The third gradually becomes available to very slow-growing plants, but it is not slightly active as is the Reverted, or as the tirst, which is altogether active. It would be best for purchasers to insist upon having the analysis of the soluble alone, as distinct not only from the Insoluble but also distinct from the Reverted.

817. Q. What is the matter with my tomatoes? The sort is Beauty, and very large and perfect, but nearly all have a big lemon-colored spot on one side.

A. They are sunburned. To prove it examine those covered with leaves, which you will find without the yellow spots. It is a good plan to sow buckwheat upon a tomato patch when the plants first come into bloom to protect the fruit against sunburn.

818. Q. I bought in St. Louis three pounds of so-called Late Flat Dutch cabbage seed, which in the bed and afterwards in the field looked all right, but now in September the plants bave lost half of their leaves.

A. No doubt you got imported seed. Late varieties of imported cabbage sced never do well in this country. You probably bought it at a cheap price and you have gotten your reward. The imported sorts lose their leaves in time of drought. No reliance whatever can be placed upon them, for our sun is too hot except in the far Northern tier of States.

819. Q. What is the cause of my onions growing staggy or stiff necked. Is it the fault of the seed or climatic condition? The seedsman from whom I bought the seed, Red Wethersfield, says it is due to the wet season.

A. Both wet and very dry seasons will tend to develop the growth of stags in onions, even from the very best seed. Too much moisture makes them so rampant they having no time to stop to bulb, and on the other hand a very dry season don't develop in them vital force enough to make bulbs; but there is another cause which often results in a staggy growth, that is in the sowing of imported seed from Italy or other cheap sections of Europe. The market gardener who' purchases cheap onion seed or get it from unproved parties deserves to have a crop of stags.

820. Q. What is the difference between Winter and Spring rye? Can the Spring rye be used for sowing in the Autumn?

A. Yes, with a fair prospect of standing the Winter, if it be mild. A first crop of Spring rye sown in the Autumn of course would not possess that hardiness of constitution which it could acquire if the system was continued for several years. Winter rye sown in Spring might not ripen, might only produce empty heads on account of an insufticient development previous to the setting in of hot weather. For example, Virginia Winter oats sown in Pennsylvania in April does very well but ripens three weeks later than Spring oats.

821. Q. What effect has the application of wood ashes upon lawns?

A. The potash of wood ashes makes the grass a deep green and strong 
in root, but it is not so stimulating to leaf production as guano or nitrogenous manure. It is best applied in Winter, as in Summer it is very likely to burn the leaves of the grass. Applied in Winter, 1000 to 2000 pounds to the acre, the rains dissolve it and wash it into the soil, where it gradually becomes assimilable as plant food to be drawn upon for use in the Spring and Summer. It is quite continuous in effect.

822. Q. Do local climatic conditious have much influence upon the Climatio growth of plants?

A. It is both curious and very instructive to investigate the effects of Plants.

Conditions

as Affecting climate upon garden vegetables grown from seed. In fact a removal of but a few miles from a locality is in some cases sufficient to produce marked results, not because of a cliange of soil, for that can be meclianically manipulated, at least on small patches for garden purposes, but entirely because of change in atmospheric conditions. Thus, for instance, Long Island farmers grow very profitable crops of cauliflower of most inviting fcrm, size and color, and with no more care than bestowed upon a crop of cabbage, whilst no success whatever can be expected with a field crop of cauliflower in the vicinity of Philadelplia, only one hundred miles distant, even though the same seed be used-all attributable entirely to a difference of climatic conditions of the two localities. The influence of climate is also observed in the case of the onion, as in Connecticut there are grown, direct from the seed, thousands of acres of profitable field crops of onions unrivaled in form, size and color, but the same seed sown in Pennsylvania will only make sets, and poor ones at that, often only stags. Again, Philadelphia-grown onion seed sown in the vicinity of Philadelphia will always make sets, but it is never profitable to make big bulbs, the climate is against it ; but in all other sections this same Philadelphia seed will develop bulbs of full marketable size.

823. Q. What is humus, and is it of much value?

A. It is a vegetable and sometimes partially animal mold, and is generally a black powdery substance in the last condition of decomposition. It may have been wood, straw, leaves, peat, or all of these and more, exposed for a long time to moisture and the action of air. A good example of vegetable mold turning to humus is that carpeting the ground in old forests, a spongy covering obstructing evaporation and absorbing rain and snow. Humus is dissipated by slow combustion in air, and in decomposition forms uitric acid. Soils are fertile in proportion to the bumus they contain, and it preserves them in a loose state for air and water to enter ; the loss of humus consequently results in a drying up and hardening of the soil. It is valuable, as under the influence of microbes and alkalines the humic matter is oxydized and a part transformed into nitrates. Without humus in the soil no plants of the legume family, and they comprise peas, beans and clover, can flourish. Possibly the reason some soils fail to grow clover is because of the exhaustion of the humus in them.

824. Q. Why is it that a large quantity of onion seed of European Imported Oniou. 
growth is so unreliable in this country, generally making stags or thick necks?

A. There are several causes; many varieties of high reputation in Europe never doing well south of Canada. The varieties not acclimated will not stand our semi-tropical sun; some other surts which sometimes do well have proved to be unreliable because too often grown in climates not favorable to the retention of their desired qualities-these causes and others result in stags, bad shapes, mixed forms and colors, and very often disappointment, and loss of crop.

New

Potatoes.
A Seed What is It?

825. Q. Are new sorts of potatoes, developed from the true seed collected from seed balls borne on top of the vines, more healthy than potatoes grown from the eyes of tubers of established sorts?

A. Often so, but not always. Seeds to produce healthly plants of any kind must be grown from healthy plants ; consequently, if true potato seed is picked off a vine of a potato plant which is unhealthy or running out, the seed itself will be disposed to run out or develop some weakness. But the seeds will vary, some will produce vines strong and desirable; but the majority from seed taken from unhealthy plants are entirely unreliable as to constitution.

826. Q. What is a seed?

A. A seed is a ripened ovule, made vital or able to perpetuate by the mysterious action of pollen working upon the female organs of the flower from whence the seed sprang. Nearly all seeds have two coats which surround the kernel, which latter, the kernel, may be the embryo alone, or it may be surrounded by a protecting and food substance termed the endosperm, variably farinaceous, oily, fleshy, corneous, or horny. The embryo is that part of the seed which starts into growth and develops the young plant, in fact it is the young plant in miniature. The location of the embryo on the seed is variable according to the species. In corn and wheat it is not in the interior, but on one side and on the surface.

Onion Thrip. 827 . Q. What can I do with my onion field on which a little insect has almost destroyed the crop by eating the soft bark of the young plants?

A. If the insect referred to has eaten the cuticle of the leaves so that they appear covered with minute whitish yellow spots almost touching, making the field almost appear white, it is the work of the onion thrip. It will also eat melon, squash, turnip and a number of other plants. Try solution of whale oil soap or kerosene emulsion.

Winter Wheat.
828. Q. In this part of Virginia we grow white Winter wheat, but the millers all want a flinty hard sort, and I want to know if I can profitably raise far Northern Spring wheats, which are all flinty, by sowing them in the Autumn?

A. You can ; and it is being done in many localities. They stand the Winter when not very severe, and the second year, grown South, do better than the first, because of having been acclimated, but by the third season the grain loses its flinty quality, becoming mealy. 
829. Q. After removing my cotton crop the fields became covered with Green a growth of green stuff, and I write to inquire if it would have any value Manuring. as a green manure?

A. Most certainly. By all means plow under the weeds and grass. To burn them is a most foolish practice. Plowed under before the seeds ripen, no matter what kind of weed, they will to a small degree fertilize the earth, and are valuable in loosening it so that air and moisture can more readily penetrate it, and the roots of cultivated crops more freely ramify. The continued application of commercial fertilizers will harden and bake any land, consequently green manuring should be resorted to whenever possible.

830. Q. What is the average percentage of the vitality of farm seeds ? Seed vitality.

A. The government of Switzerland has established a Seed Control Station at Zurich, and during the year 1892 made nearly 6000 official tests of vitality. The average was, of

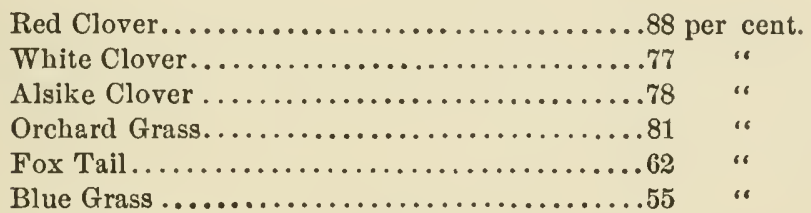

The Austrian Seed Control Station in 1892, paying special attention to the subject of Sugar Beet seed, established an official standard of 80 per cent. of germinating clumps as indicative of excellence.

831. Q. Are all the vegetable oils of the same nature?

A. No ; they nearly all differ, and are distinct in turn from the essential

oils of the same plants, the essential oils being all volatile. Fixed fats and oils are found in many agricultural seeds, notably in rape, or colza, flax, hemp, cotton, castor beans and peanuts. All these contain from 10 to 50 per cent. of expressable oil. The essential oils are obtained by boiling and distillation, and it is these oils which give the odor to plants.

832. Q. My attention has been called to the condition of the leares of Mining Flies. my beets and radishes, all of which are channeled out or mined by some worm. How can I stop it ?

A. The injury is done by the larvæ of some one of the mining flies. There is no remedy to apply to the present crop. The only course is to attempt to destroy the insects after they drop to the earth to remain all Winter. This may be partially done by oil, salt, lime.

833. Q. Have you a table giving the number of plants to the acre of Plants those sorts of garden vegetables which are usually or sometimes started to Acre. under glass for transplantation into open ground?

A. The number of plants set to an acre depends on the distance between the rows and the spaces between the plants in rows, some market 
gardeners setting more than twice as many as others, dependent upon strength of soil. The following is an approximation of the quantities :

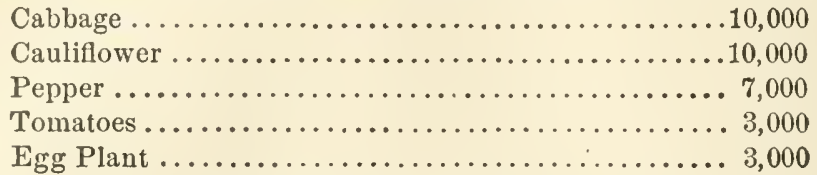

Origin of some Double Flowers.

Soil

Exhaustion.

\section{Loss of}

Soil

Fertility.

roots,

Various

Kinds.
834. Q. How do gardeners obtain double flowers of ornamental plants?

A. A double flower is one in which some or all of the stamens or pistils are changed to petals or flower leaves, or a flower in which the normal number of flower leaves is greatly increased. The change results in the loss of power in the plant to develop seed. It is often entirely brought about by starvation of the growing plant, sometimes by debility in the seed, a consequence of age or exposure.

835. Q. What proof is there that plants exhaust the soil?

A. A good proof is that the soil in pots or tubs is exhausted by plants remaining in the pots or tubs for a considerable time, the effect being smaller foliage and flowers, and weak branches. As these conditions can be relieved by the application of manure it is clearly aemonstrable that the soil was exhausted.

836. Q. How do soils become exliausted?

A. Partially by the loss of nitrogen in the soil. large amounts of nitrogen are lost by natural soil drainage, the rains carrying down the nitrogen to a depth beneath the reach of roots. This especially occurs on fields not covered with crops, for when so covered the crop evaporation keeps water up near the soil, but when bare the water sinks, taking the nitrogen down. This is one argument for catch crops, that is, temporary crops, quick growers, as Scarlet clover, or Cow peas. These cover the ground, stopping drainage, and the leeching away of nitrogen, and if the catch crops are well selected they add more nitrogen through their growth. Nitrogen also becomes exhausted partially through a diminution in lumus, which by a chemical action and change affords nitric nitrogen. Nitrogen, however, is not the only food constituent which subsoil drainage removes, for there may be a loss of phosphoric acid and potash also.

837. Q. What are the names and distinctions of the fleshy, earthy stems of plants?

A. They are all classed as roots, but they are distinguished from roots proper by producing regular buds or bearing scars indicating formed leaves. A rhizom is a thickened starchy root stem, as illustrated by the calamus or by the wire grass. A tuber is an enlargement of a bud of an underground stem illustrated by the white potato. All tubers are rich in starch. A bulb half in and half out of ground is an aboreviated stem, formed of the basis of thickened leaves termed scales, illnstrated by the onion. Bulblets are small bulbs offset from large bulbs, often seen on the outside of hyacinths. Corms are like bulbs but solid or without 
scales. Roots, a term so frequently used in agriculture, indicate those solid fleshy portions of plants which grow partly in and partly out of ground, as beets, turnips, or carrots. The out-of-ground and underground portions of beets have somewhat distinct cliaracteristics. Nitrogenous materials are more concentrated in the underground parts, while sugar is found mostly in the above-ground portions.

838. Q. Why do the flowers of some garden vegetables retain their Retention of freshness so much longer than others?

Freshness.

A. Some plants pollenize much easier than others, and nature seems to give a physical strength to certain flowers to retain their freshness while awaiting pollination. It has been observed that quick-withering flowers retain their freshness for unusual periods if not pollenized, seemingly awaiting the event for which they were created, but as soon as the pollen grains touch the pistils the flowers immediately lose their freshness.

839. Q. In the case of turnip seed, is new crop better than old crop? Turnip Seed.

A. If the old crop is not older than onc year and was well harvested and since well kept, it is as good as new-in fact better, as it will sprout more uniformly, being more susceptible to a slight degree of moisture. New crop turnip with some persons seems to have a charm, but it comes in late, seldom ready before the 10th of July, and what is gained in vitality is lost by delay in planting. Of course two-thirds of what turnip seed is sold as new crop is old crop; not always of the preceding year, however, for sometimes it is old cnough to vote.

840. Q. Is there any way besides trapping by which I can rid my farm Moles. of ground moles?

A. Try injecting into the mole runs, at distances of ten feet apart, a gill of liquid bisulphide of carbon; the poisonous fumes may kill the moles or drive them away. Another remedy worth trying is to place small pieces of meat with strychnine upon it in the runs.

841. Q. Is there any standard weight for a bushel of onion sets ?

A. No and there cannot be for the reason that sets vary in cording to size and density, and they decrease in weight constantly from time of harvest to time of planting, which may be a period of six months. The only fair and just way of selling onion sets is by the bushel, and they should be sold by a stroke busliel, for that measure is the same everywhere, a heaped or rounded bushel varying more or less according to the spirit of the measurer.

842. Q. What is the Irish shamrock?

A. It is the White Dutch clover, common everywhere.

843. Q. A friend in Brazil sent me some watermelon seeds from fruit said to be the best in Rio, but upon trial I find them little better than Foreig pumpkins?

A. Just the experience of every oue. The writer has repeatedly got the best of sorts of all seeds from South America, and they seldom prove of any value in Pennsylvania because of the change in climatic conditions. 
Pollination of 844. Q. How do water plants growing under water effect the pollina Water Plants tion of their flowers?

A. Sometimes the male flowers are borne on short stems, and when perfected detach themselves and rise to the surface, where they meet the female flowers. At other times they are borne on long stems rising to the surface. The female flowers are always borne on long stems or peduncles reaching to the surface of the water where the pollination only takes place. As a rule water plants will only grow where the flower stems can reach the surface.

Latitude Affecting Garden seeds.

Adulteration of Seeds.
845. Q. What latitude or climate is best suited for the production of garden seeds

A. It is well-known that garden peas do best under the atmospheric influence of the Great Lakes, as along the Canadian shores of Lakes Ontario and Erie, and along the American shores of the same lakes, or within the influence of lake air. Sugar corn, on the other hand, grown in New England has long been proverbial for its high sugary qualities and retention of type, qualities which it loses in the West, the sugar corn grown there becoming thicker and altogether larger and more mealy in the grain, instead of retaining its qualities of lightness, and corneous, and oily character. Vegetables for the production of small seeds develop best in the sections indicated by New Jersey, Pennsylvania and New York, as there the full flavor of the vegetable is retained, and outward appearances of the seed stock remain unchanged, which is not the case when the same vegetables are grown on the richer soils of the West. The West produces very showy mammoth vegetables, but Eastern seeds grown on slower soils are more true in their disposition. The district referred to, styled by the Census Bureau the "Pennsylvania District," has a better climate for the full perfection and full retention of typical qualities of shape, size, color, flavor, as its climate is very favorable to insuring perfect pollination, consequently a higher vitality in the sceds than from districts farther North, South, or West.

846. Q. Is there a seed adulteration law in the United States, as in England?

A. No ; but there should be to prevent like frauds as held in checkonly in partial cheek, however-by the English law which was passed about 1870 , and which laid heavy penalties for adulteration with dead seeds! Before that date it was a common practice in England when seeds fell in vitality to a pereentage too low to sell, to roast them in kilns to de. stroy all remaining vitality. Kilns for such purposes were established in various parts of England, and they did a thriving business. Any kind of turnip, cabbage, radish, beet, or other seed of no value, because of low vitality, could be killed and mixed with some high-priced variety of the same family, thus lowering the cost of the whole. In the case of clover, quartz rock was ground into sand, graded to size, colored like clover, and used as an adulterant of clover. While the English law pro. hibits the sales of adulterated seed in England, there is no law to prevent adulterated seed being sent to America. 
847. Q. What can I do to eradicate the wild carrot?

Wild Carrot.

A. Pulling up the plant or cutting off below the surface of the ground is the only remedy.

848. Q. What are the merits of Dwarf Essex rape?

Essex Rape.

A. It is a good, lealthy, broad-foliaged, palatable plant for feeding cattle or sheep, producing twenty to thirty tons of green stuff to the acre. It grows three feet high, and is lighly recommended, especially for sheep feeding. It covers the surface so densely as to smother out all weeds and to kill twitch or quack grass. It should be sown in drills or rows at twenty. four to thirty inches apart, and at the rate of two pounds to the acre.

849. Q. What is the substance termed pollen?

Pollen.

A. Taken as a whole, it may be described as a dust of microscopic parts or grains of defined shape, varying according to the family of plants producing it. It is the vitalizing portion from the male organ of a plant, and is intended by nature to be brought into contact with the female organs of flowers, whicl occurs by its falling upon them, or by being car. ried by insects. It retains its vitality for varying periods, in some cases but for a day, in other cases for months. It can be carried by the wind for many miles and thus produce many curious hybridizations. When a grain of pollen reaches the mouth of the pistil, which is frequently moist, the pollen grain immediately develops a long tube which penetrates, seem. ingly by some mysterious instinct, the pistil no matter what its length, till it reaches its base, wben some hidden operation occurs necessary to the development of seed which will perpetuate the species. The passage of the above-described tube from the lip of the pistil down to the ovules at its base may occur in a few minutes, or may take days, or weeks, accord. ing to the species of plant. Sometimes the distance is equal to 9000 times the diameter of the pollen grain, a familiar example being found in the long silky threads of corn sometimes nearly two feet in length. Pollen graius are produced in great numbers, often a single flower producing 100,000 grains. It is calculated that the pollen produced on an acre of wheat amounts to fifty pounds.

850. Q. What is the influence of size and weight of seed upon the Seed as to growth of plants?

Size and

A. Full plump seeds will generally sprout quicker than smaller seeds vitality. of the same kind, and seeds under size will generally produce weaker plants than those from plump heary seed, but plants from the small seeds will generally be found to mature a degree earlier and occasionally be quite as productive. The plants from the plump seeds will generally be more vigorous in foliage, as they obtain a better start immediately after germination.

851. Q. Down here I cannot obtain all the stable manure I require and commereial want to know what you consider the best commercial fertilizer?

A. As there are over 1000 brands of commercial fertilizers made in the United States, it is impossible to say what is best, for so many are good, 
and so much of value depends on costs of freight. In your locality the best is that one which produces the most telling effect for the least outlay of cash, and that information you can best get by conferring with your neighbors, for their experience is far more practical than anything the writer can suggest without a knowledge of your soil conditions.

Barnyard.

852. Q. How many loads of barnyard manure should I put on my gar. den of one acre, and when should I apply it?

A. Seven to ten tons to the acre broadcasted in the Spring and plowed. under as soon as spread. Barnyard manure so old and rotten as to be short like compost is already reduced to half its value, and on the other hand when so long as to be like straw is but of half value.

Cockle. 853. Q. How can I prevent cockle in wheat?

A. Sow clean seed, or if you cannot purchase absolutely clean seed make it so by sieving, riddling, or liand picking. Of the crop grown from this seed take a portion of a field, one to twenty acres, as may be required, and pull out by liand every cockle plant, and cut off every head of rye till the stock is uniformly pure.

Germination 854. Q. What causes seeds to germinate?

Cause.

A. Moisture and temperature supplemented by oxygen. Of moisture various amounts are required, most seeds requiring an absorption of over their weight in water. Some must be completely soaked in water, and others only have the smallest quantity. Moisture penetrates the seed, swells the albumen, dissolves dextrine, and is the vehicle which conveys nutrition to the young plant in the seed. Of temperature there is an equal variation. Wheat will sprout $45^{\circ} \mathrm{F}$., but the most favorable range of vegetable seeds is from $75^{\circ}$ to $90^{\circ}$. Peas and onion seed will sprout at a moderate temperature. Beans and melon seeds require a high tempera: ture. Low temperature retards the formation of lateral rootlets, buds and leaves. A high temperature causes their rapid development. Oxygen appears to be necessary to sprouting seeds to change the starch into dextrine and then into sugar. The oxygen is obtained both from the air and the water.

Clover Seed.

855. Q. How much clover seed is annually saved in the United States?

A. The late Census report gives the clover crop as 2,753,000 bushels annualiy, and the grass seed crop in the aggregate as 3,000,000 bushels.

856. Q. My watermelons all have big round brown spots on top, most Watermelons seriously injuring their salable qualities. What is the cause?

A. Sunburn. Next year broadcast buckwheat before the vines come into bloom. By the time the melons are ripe the buckwheat will have risen above them, partially protecting from the sun.

Nitrogen source.

857. Q. How do soils obtain nitrogen from the air?

A. It is theorized-really believed-that a part of the free nitrogen of the air enters into the cycle of plant growth through the agency of bacteroids, the product of miscroscopic organisms. The cryptogamic plants on or near the surface of the soil, flourishing more on damp soils than on dry, collect and assimilate ammonia to au extent about equal to the amount 
present in the soil before their growth. There is a continuous loss of nitrogen in the soil, not alone through the demand upon it by cultivated plants, but by leeching down, or by natural soil drainage and by evapora. tion.

858. Q. On my farm are lots of wild parsnip infested at seed time with Web Worm. a web insect. It may get on other plants. How can I destroy it?

A. It is almost impossible to destroy this worm. The writer has tried everything to save patches of twenty acres of parsnip at a time and without success. Your best plan is to mow off the parsnips before they shoot to seed and thus starve out the insect.

859. Q. In 1894 I bought from your house 1500 pounds of Jersey Cnenmber pickle cucumber and drilled nearly all of it, getting a crop as fine as variation. respects form and productiveness as ever seen in this locality. This Spring I drilled what seed I had left over, about 300 pounds, and cannot recognize the product as from the same seed, but $I$ know it was, and write for an explanation.

A. Climatic altogether, the type or strain is just the same, but the conditions of growth have been different : more or less rain or drought, cold or heat; a variation in the degree of vivifying sunshine; more or less fertility of soil, influenced in both cases by preceding crops; insect, or fungous ravages above or under ground; variations in periods of drill. ing-all these and as many more influences determine results.

860. Q. What manure should I apply to my onion crop? I can't get Manure stable dung.

A. Previous to drilling the onion seed, broadcast 400 to 500 pounds to the acre of dried blood, dried meat, or fish, or guano, to give ammonia or nitrogen; and 500 to 600 pounds wood ashes to the acre, to give potash. Superphosphate is not so necessary as the nitrogen and potash, which makes tissue; for where grain or other seed is not in view, phosphoric acid is not demanded so much as the other two components of vegetable food.

861. Q. I have two lots of seed of Zig Zag Adams Early Table corn, Corn one grown in Pennsylvania, the other, a far better looking sample, grown Variation. in Illinois. Why is this?

A. Exactly so. The rich soil of the West will always produce the most showy grain, the largest and heaviest ears, the tallest stocks, but all at the sacrifice of earliness. If you want a horse corn get seed off of prairie soil, but if you want an Early Table corn get it off of the older soils of the East.

862. Q. How big do you grow watermelons in Jersey?

A. The writer has seen them of 100 pounds, but such are unsalable. Size.

for Onions.

No one will take a hundred-pounder as a gift, and anything over fifty pounds sells slowly because the experienced one knows that it is coarse in flesh. The forty-pounder is big enough for any one family. Big things in vegetables are never the best. Don't be influenced by size-look for quality. 
Potato

Stem Borer.

Garlic.

Leek.

Corn,

White Flint.
Top Onion.

863. Q. Some worm is in the stalks of my potato patch boring them from end to end so that they are drying up. What can I do?

A. You can't do anything. The pest is most likely a grub known as the potato stem borer, a worm about a quarter of an inch long. They begin their work in June and frequently eat out the entire heart of the stems. Of course they reduce the crop, and there is no remedy known to destroy the grub while working within the stem. After harvest burn all potatoes vines and everything else upon the field.

864. Q. In what way does a shallot differ from an onion?

A. A shallot seldom produces seed, and its bulbs when planted divide into a number of cloves which remain attached to a common disc, and finally become as large as the original bulb. The true shallot grows about an inch in diameter, is pale gray, and is much elongated, but there is a bastard form nearly round.

Potato Onion 865. Q. In what way does the Potato onion differ from the usual form of onion?

A. It does not produce either seed or bulblets, and is only propagated by cloves formed underground, same as in the case of the shallot. If well-developed cloves are planted in September, fair-sized edible onions may be harvested in April, but if left in the ground several weeks longer the bulbs will split, producing many small ones, the largest of these in time producing cloves, the smallest forming edible bulbs. Potato onions are very dificult to keep'when taken out of the ground, as they decay rapidly.

866. Q. Describe the difference between Top onions and ordinary onions.

A. Top onions of large size are grown from sets or bulblets produced the preceding year on the top of high stalks sent up from large onions. There are two forms, those producing bulbs with one heart and those of three to five hearts. Only the form producing the single-hearted bulblet is valuable, the others splitting up into many undersized plants which never reach a good size and seldom ripen down their tops. The single-hearted sort is worth three times the price of those having divided hearts, which are next to valueless except as scullions.

867. Q. How does garlic differ from the onion?

A. The garlic bulb, which is pungent and strong in flavor, is a com. pound one, comprised of six or more cloves within a membranous skin or envelope, generally white or rose color. It is propagated by cloves produced on the top of high seed stalks after the style of the Top onion.

868. Q. What is the distinction between a leek aud an onion?

A. An onion is bred to develop the edible portion as a round or a flat bulb, but in a leek the plant has been bred to develop numerous thick leaves, enveloping one another at the base and for a considerable distance above it, forming a thick fleshy neck of edible quality. The leek produces black seed similar to onion seed.

869. Q. Is White Flint corn of any use except for hominy purposes ? 
A. Very valuable for making a white meal; also excellent for stable use as a feed corn. It is a sort early, liard, a good ripener and a fine keeping variety. All Flint corns are very nutritious, as they contain much oil.

8\%0. Q. How late can I plant Sugar corn with a reasonable certainty of Sugar Corn, making a crop of roasting ears-and what is the best variety for this pur. Late Planting pose? We have frost October 15 th to 20 th.

A. The special variety known as Landreths' Sugar corn will mature when planted in the Spring in about eighty days from germination ; but sown for an autumn crop it does not develop so rapidly, as the rainfall and temperature of the nights are not so forcing, the plant taking quite ten or fifteen days more to develop edible ears. In May and June Spring-planted corn grows with great rapidity, but under the cooler nights of September it almost stops growing at night, while early in the year an early crop does nearly all its growing at night. Therefore, to ripen for table by the 15 th of October, it will be necessary to plant about the 15th of July. A quicker but smaller sort is the Crosby, which might be planted as late as the 25 th of July.

871. Q. Which is the flower of Indian corn, that on top of the stalk or Tassel that on the end of the ear?

of Corn.

A. Both. That on the top of the stalk, called the tassel, is the male flower; that at the end of the ear called the silk, is the female. This latter is composed of filaments or long silky hairs extending from each grain to the outside of the husk of the ear: Some of these threads are often eighteen inches long. Each thread or hair has an opening or a mouth to receive the invisible pollen from the male, and unless each thread so receives a grain of pollen no seed possessing a vital germ or full-size will develop on the spot to which the thread is attached. It is estimated that the male flowers of corn are so fertile in pollen as to produce nine thousand pollen grains to each thread of silk-yet only one grain is needed to each thread.

872. Q. I am too far away from a big town to obtain large quantities Stable of stable manure, and inquire if I can manufacture anything to take its Manure. place?

A. Tes ; keep pigs. Feep them in pens, numerous pens, that they can be changed from one to the other ; those adjoining a barnyard not too big, say 30 by 90 feet, with an adjoining field of one to two acres, in which they can run in occasionally for exercise, and while the pens and yards are being cleaned. Do not let them run wild, but keep them in closely defined enclosures. Into the barnyard, which should be dished to the centre to hold water, dump all kinds of manure-making material, as straw, corn fodder, weeds, leaves from the woods, swamp muck, sawdust, anything that will decompose or hold fertilizing liquids. Do not let any of the manurial juices run away. Into the yard dump materials lauled in so that the pigs will tramp them down and root them over and over. Frequently fork them over, and at the end of six months it will be 
surprising how much exceedingly valuable material has been accumu. lated. Experience on Virginia plantations, so located that stable manure cannot be obtained, prompts these remarks, as 150 pigs kept in three barnyards have annually produced an immense quantity of exceedingly valuable manure. The value of the meat of the pigs should more than pay for their feed, the manure being all profit. Of course such a piggery should be kept distant from the farmer's dwelling on account of offensive smells and flies.

Runners in Peas and Beans.

873. Q. What causes runners in peas and beans?

A. Sometimes perfectly true types of peas and beans will send up what appear to be running tendrils, or will produce what appear to be late vines, both due to the accidental location of some seeds over lumps of manure, or due to the conditions of deep or shallow rooting, or to a rainy season, all these being purely accidental fluctuations in the apparent character of the stock. Runners, however, are generally due to an unselected stock, to a bad strain of blood. All peas and beans, if neglected, will become partially wild or rampant. They can only be kept within prescribed limits by constantly throwing out all vines in which any indication of a departure from the true type is observable. A disposition to grow wild is inherent in all types of peas and beans, just as it is in the human system; and when not checked by selection, that disposition develops so rapidly as to completely change the character of the stock in three or four years.

Germination. 874. Q. In planting garden seeds of various kinds I sometimes find that seed from the same package planted at different dates gives varying results as to the number of seeds that sprout. Can you account for this?

A. If the seed is from the same package and the germinating qualities seem different, it is obviously due to soil, or to atmospheric conditions, or to your system of treatment, of either soil or seed. For example: If, after preparing the land in one instance, the seed is sown at once in the damp soil, it is likely to sprout at once; but if in the other instance after the land is prepared it be left to dry and bake from one to two days, or a week or more, before sowing, then the seed will be slow to germinate, if indeed it does not fail altogether.

Bean Soil. 875. Q. What soil is adapted to bean culture?

A. It is an old saying that any field is good enough for beans, but that is a mistake, for this crop profits as much by sowing on good soil as any other. On strong soils the crop sometinies reaches thirty bushels of dry seeds to the acre, but often on thin soils not more than six or seven.

876. Q. You sent me last month a lot of Golden Wax beans with very

Variation in Beans. little white upon the dry seeds. Now I get another lot from you nearly all white. Can they both be true?

A. Yes; they may differ very much in the extent of coloring on the dry seed and yet both be equally good when in edible pod. In fact, there may be a half-dozen degrees of coloring in as many lots, due partially to the stock seeds planted, but principally to the soil on which they 
were grown. Red Valentine beans differ also in degrees of color and in shape and plumpness, as some are grown on heavy soil, others on light sand; some as an early crop, others as a late crop; yet all may be equally early and good in quality of edible pod. If there is any choice between lots of Red Valentine beans the small misshapen ones are the best, without respect to the depth of coloring.

877. Q. How is it that two lots of Bloomsdale Ruta Baga seed received Size of Seeds. from you at intervals of ten days were quite different in color and size of seed?

A. We grow our Ruta Baga seed on many different fields, some being sand and gravel, others clay, and these in three different States, consequently the crops are ripened at different periods and exposed to variable fluetuations of soil conditions and more or less heat and rain. No sane man could expect that such seeds could be of uniform color, or plumpness, or indeed appear to be the same thing. The grade or quality of all is the same as all are grown from pedigree roots.

878. Q. Does pollination in the case of garden vegetables occur with Pollination. equal certainty both in Northern and Southern climates?

A. It is only absolutely certain, that is, certain up to the normal degree, in climates of intermediate temperature and conditions. Burning heats or extended droughts of tropical countries interfere partially with the process, so also do cool to cold nights of Northern latitudes. Under excessive and long-continued heat the stamens and pistils dry up prematurely, and under conditions of too low a temperature at nights they do not develop to such a degree as in districts where the nights are hot. There the pollen is produced in perfection, and is so light that pollination is certain to occur.

879. Q. My section in Indiana has always been celebrated for the excel- Flavor in lent flavor of its cantaloupes, but this year no melons for twenty miles Cantaloupes. around me have the usual good taste. Can you explain this ?

A. Nothing unusual in this; it often happens, but it is hard to explain. Probably due to a want of sunshine, or too much rain, too much drought, or to some unusual climatic influence unexplainable. It may not occur again for years, but just such conditions are certain to be experienced in time by all melon growers.

880. Q. Can watercress be grown in the absence of a running stream of Watercress. water. If so please give me directions?

A. Yes; it is often grown during Winter in vegetable forcing houses. It requires a moist atmosphere and lots of watering, and must be grown in a cool shady position. To start the seed it should be sown in pans or trays, and after the plants are two inches high pricked out at four inches apart. The watercress belongs to the nasturtium family. Under glass, or in a garden, watercress never reaches the vigor of plants grown in a running stream.

881. Q. Why do radishes sometimes become pithy and tough?

A. Radishes well grown are grown quickly, and under those circum- 
stances never become pithy and tough till they reach a size undesirable for table use. It is a mistake to wait for radishes to grow big, they should be eaten small, when a little over one-half an inch in diameter; then they are bright, crisp, of good flavor and attractive. On poor, hard soil, or soil infested with grub worms or fungi, they nerer can he expected to grow fast nor to be good, either large or small.

startingseeds 882. Q. How can I best start my seeds in the house to be afterwards

for

Subsequent

Transplant-

ing.

Sowing Hlower Seeds. garden ?

A. When it is desired to hasten the development of plants, they may be sown in the conservatory or in boxes within the house. Those who have greenhouses hardly need directions, but for those who have had less experience we drop the following hints :

Procure shallow boxes, trays, or broad pots from two to four inches deep. The bottoms open for the free passage of water, else the earth will bake and become sour. Seeds will not germinate satisfactorily or thrive in a wet soil.

Prepare a mixture of one-third leaf-mold cut fine, one-third clean sand, and one-third finely pulverized stable manure, moisten the mixture thoroughly, and fill into the boxes to within a half-inch of the top-gently patting down the surface to a level. Upon this distribute the seed, and cover just out of sight, by sifting over the seed the finest dust procurable, settling the seed down with a fine spray of water shaken from a brush, a heavier application baking the surface.

Place the boxes where they will remain at a temperature of between $60^{\circ}$ and $70^{\circ}$, applying water with a brush or fine rose when the surface becomes dry.

When the seedlings are half an inch high, they may be transplanted to other boxes, placing the tiny plants about one to each square inch. When these become so large as to crowd each other, they should again be trans. planted to the garden, or to other boxes according to the season.

883. Q. Give me some directions about sowing flower seeds in my

A. Flower seeds being usually small and delicate, the land to receive them must necessarily be carefully prepared, otherwise the cost of purchase and labor of sowing will be expended in vain. Large stones, clods, and other material out of place, should be removed after the earth has been deeply dug and fertilized; but the earth should not be made so fine as to become pasty under moisture.

The best results will generally be obtained by the beginner by concentrating the crop, or sowing all the varieties in one plot or bed, or a portion of ground, whatever its size may be, sufficiently large to hold all sorts placed in parallel rows at one foot apart, and this concentrated plantation can be carefully weeded, and otherwise attended to during the early stages of growth.

Afterwards, when one or two inches high, the young plants can be removed, on a rainy or cloudy, damp day, to permanent positions; here 
the earth must be carefully prepared for their reception, being especially enriched by a previous application of very short, well-rotted stable manure or compost.

In the after-culture the most important matter is to keep the clumps well thinned, for crowding will defeat all other preparations, while space, which at first seems four times too much, will serve to develop robust plants, which, by their ample leafage and well-developed flowers, will amaze people not familiar with the conditions necessary to successful plant culture.

884. Q. How far North are garden vegetables cultivated.

A. Some time ago The Philadelphic Record newspaper company sent Gardens. an expedition to Alaska, and among the reports was the following: Upon arriving at Sitka, nearly 5000 miles away from Philadelphia, and in latitude 57 degrees, as far north as the highest part of Labrador, the Record men strolled along Lincoln street, which is Sitka's only business thoroughfare, and read on one of the most prominent signs in that place that Landreths' Extra Early Peas were on sale within.

885. Q. Are not some of the descriptions of vegetables offered by some seed merchants very highly extravagant in word painting?

A. The Rural New Yorker, in its issue of July 9, 1892, thus refers to a new variety of cabbage: "Here is a new variety of cabbage, which, if our readers have any faith in the first announcement of its presentation to the public, may excite general interest. We print the advertisement as received, omitting only the name of the introducing firm :

" "The Extravaganza Cabbage (Munchausen Stock). Of all the varieties of cabbage which have ever been offered since the world was made, especially those described in the picture seed catalogues of the present day, no sort ever equaled this cabbage for every good quality which trenchant words can express, or the fertile mind conceive, and we would say no cabbage of the future can possibly ever equal it, had we not a variety lying back to introduce next year which we are going to advertise as infinitely the superior of the Extravaganza, and we expect every year to have a still better one than the year preceding.

“"We are getting up a picture of the Extravaganza, which, by comparison with other well-known objects purposely placed near it, will show that this cabbage is as big as a tobacco hogshead, and the description which will accompany the picture will prove, if words have any power, that its flavor is as sweet as sugar, its texture as fine as satin, and its habit exceedingly early or so rarely late, or so something else, as to eclipse every cabbage ever before known, and, above all, its freedom from the attacks of insects is phenomenally remarkable : indeed, an insect which simply flies over it falls dead within twenty yards. To the market gardener it is a boon, as it sells itself, its laughing face beaming with such benevolent expression as to win the admiration of every purchaser at once.'"

886. Q. Will it pay to grow turnips especially for feeding to cattle? 
A. "In this country the turnip and the ruta baga, or 'Swede,' as it is familiarly called, is more generally cultivated for stock-food than any other root-not that it is the best, but because it can be so readily grown, and at small cost. While beets, mangolds, carrots, kohl rabbi and parsnip demand an entire season to mature, the turnip is of so quick growth in our climate, that within a few weeks only after sowing abundant supplies may be in hand.

"The writer cannot, however, but maintain that, though at some increase of labor in the production, no expenditure on the farm may, in the long run, pay better than an annual crop of mangolds and carrots, even if raised only in sufficient quantity to alternate with the ruta baga, and thus the food be varied; a change which the milch cow, the stall-fed ox and the sheep crave equally with man. . . . .

"Nothing we know of is so efficient, considering the small cost of time and money. Seventy to eighty days will make the crop, and at a cost not excceding three dollars per acre. The preparation of the soil and climatic adaptation of the locality is an important prerequisite to success, both as respects the productiveness of the crop, and its cost, for it is manifest that, however valuable and desirable may be any object we seek, the cost of obtaining it may be disproportionate to its value ; such is especially the case with all products of the soil." -Landreth Farm Notes.

Hay Measurement.

887. Q. Give me a rule by which I can measure or estimate the weight of hay in a mow ?

A. Hay in a mow ten feet drop, put in in good order, and not too ripe when cut, ought to average one ton to each 525 cubic feet. The compression increases rapidly as the height increases, and a mow of the same hav, fifteen feet drop, would probably turn out a ton to 475 cubic feet, if not even to 425 feet. All such guessing, however, is very hazardous, and it is always safer to buy or sell only by actual weight.

Horse-Radish 888. Q. To get horse-radish must I sow seed or get roots?

A. This plant, seldom producing seed, is propagated from sets cut from old roots, and in market garden culture nearly always planted as a succession to a Spring crop which by time of removal leaves the horse-radish well established. The sets are planted in rows of about two feet by eighteen inches frequently among Spring cabbage. Holes are made with a long planting stick into which are dropped the horse-radish sets to a depth that the crown will be three inches under the surface. It will only succeed in highly fertilized land, and each year should le planted afresh. In garden culture the sets are sometimes planted in the upper end of round drain tiles sunk into the ground and filled with earth, the radish roots being thus directed straight downwards. Yield about 150 bushels to the acre. Sets, per doz., 15 cts.; per 100,50 cts. ; per $1000, \$ 4$.

Cheap Seeds. 889 . Q. What do you mean by cheap seeds? What are they?

A. Sometimes they may be passable, but nine times out of ten they are worthless. They are cheap because grown purely as speculative crops, grown generally from seed stocks, cheap and bad to commence with, and 
the crop resulting left to bloom and seed without the removal of hybrid or cross-bred forms, thus the mixed blood of the parent stock is developed to an increased percentage in the offspring.

The papers of the day are now discussing investigations and developments respecting adulterations of drugs, but the frauds cannot exceed in extent those practiced in some quarters by the seed trade. So great was the adulteration of seeds in England that Parliament passed an Act a few years ago fixing heavy penalties for such frauds, but they still continue, and are common in every country of Europe.

The least objectionable fraud is the process of cheapening prices by mixing into new crops a proportion of old seeds heated till all vitality is destroyed-such mixed stock will vegetate only to the extent of 50 per cent., often much less.

The vitality or germinating power of seeds is not, however, the most important question to the gardener, for if seeds fail to sprout the first cost is the principal loss. The quality of the vegetables seeds may produce, is the all important question, and that can only be determined when, perhaps, it is too late in the season to remedy an imposition.

Better every grain should be dead than mixed or hybridized. The critical gardener considers well before he makes his purchases, and to the experienced planter nothing is so suspicious as "cheap seeds"

890. Q. Tell me something about watermelon culture?

A. Watermelons do well upon sod ground, or upon land prepared for Watermelons their reception by plowing down a crop of Winter wheat or Winter rye, the sod or grain aerating or keeping loose the soil. When the apple is in bloom the seed is planted in hills at ten feet apart in each direction. Two large shovelsful of well-rotted stable manure dug and tramped into each hill and covered with earth.

The cultivator should be prepared with quite four pounds of seed to the acre that he may have a reserve for replanting in case of destruction of his plants by insect depredations or beating rains.

One vine alone to the hill should be allowed to. attain perfection; with four hundred and fifty hills to the acre, there should, be nine hundred first-class melons.

Philadelphia commission merchants pay for prime melons, as a highest price, forty dollars per hundred; as an average price ten dollars per hundred. They cease to be profitable to the trucker when bringing less than four dollars per hundred. First-class melons are always in demand, but the market is frequently overstocked with small fruit.

Much of the melon seed offered throughout the country is the product of immature and deformed melons remaining in the field after all the choice fruit has bcen selected.

891. Q. What is the cost of bisulphide of carbon?

A. Any druggist can obtain it and sell it at a price of about 15 cents Bisulphide. per pound, and it can be had in tin cans of five, ten or twenty pounds each. It is explosive and very injurious to breathe. 
Garden Plan. 892. Q. I have a piece of land 150 feet long, about one-sixth of an acre, and would like you to send me a diagram plan for laying it out.

A. The varieties and quantities here named will cost about $\$ 11.75$. The rows are arranged so as to be worked by horse cultivator. The six-foot bed of small vegetables will have to be worked by hand.

WIDTH 49 FEET.

Garden Plan.

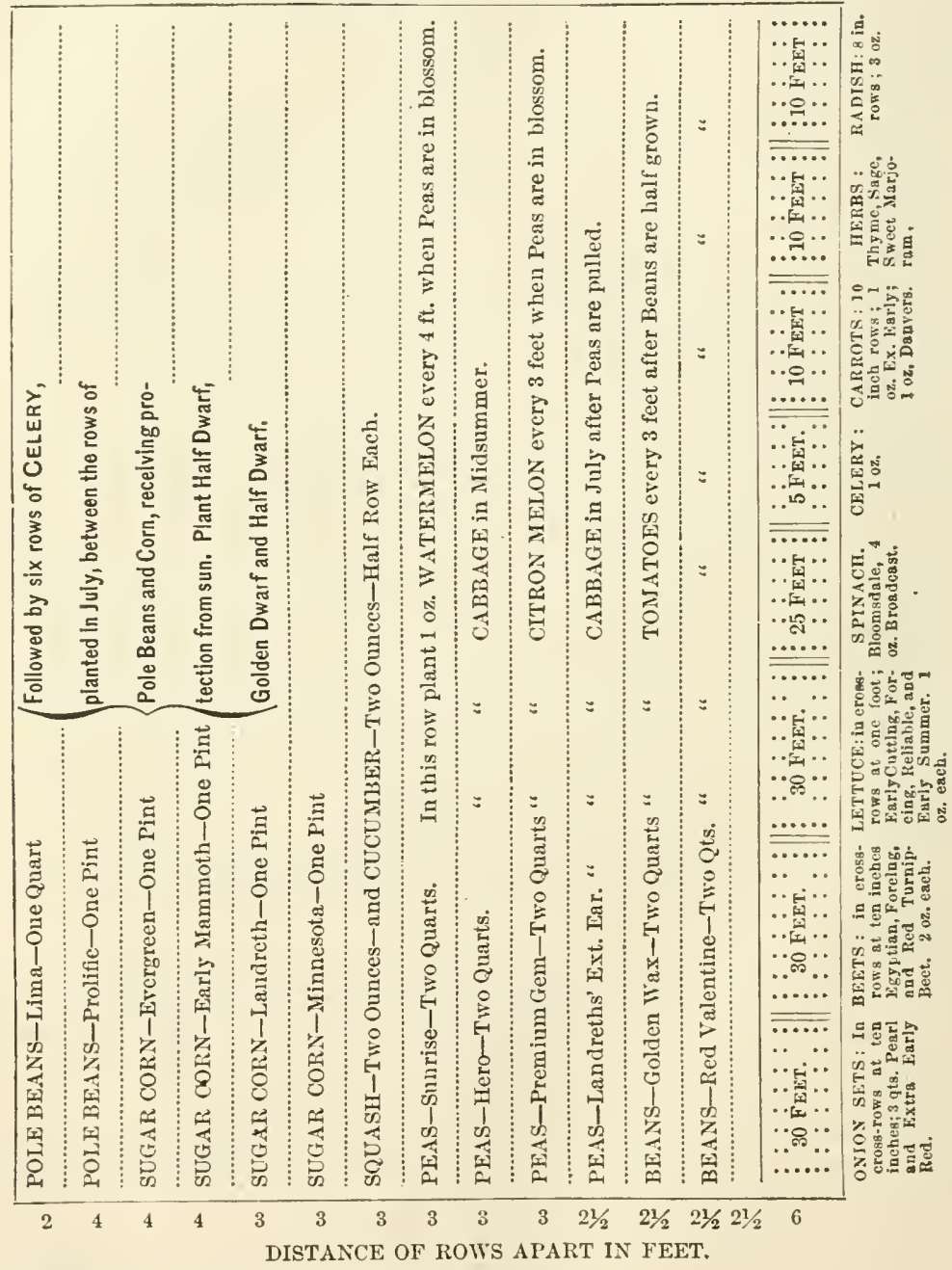

Cantaloupes. 893. Q. How are citrons planted in Jersey?

A. Cantaloupes or citron melons, as they are termed in Jersey, do well 
upon sod ground or upon land prepared for planting by plowing down a crop of Winter wheat or Winter rye, the sod or grass aerating or keeping loose the soil. Two ounces of seed to 100 yards of row.

The seed is planted at about corn-seeding time or when the apple is in bloom, in hills about four-and-a-half feet in each direction. Two shovelsful of well-rotted stable manure being tramped into each hill and covered with earth. The large long melons like the Reedland Giant and Casaba are generally sold by the hundred; melous of the ordinary form and size are sold by the basket of one-half to five-eighths bushel capacity.

Philadelphia commission merchants pay as a highest price $\$ 1.50$ to $\$ 2.00$ per bushel. As an average price forty to fifty cents per bushel, Cantaloupe melons are frequently a drug in the market.

894. Q. Why did you say seed purchasing was a matter of confidence? Confidence in

A. Because it is so. The man who buys dry goods or groceries, corn or seed cotton, can, to a very considerable extent, judge of the quality and value of Purchasing. the article. This is not the case with seeds. Simply because a dealer says a certain cabbage seed he holds in his hand is Large Late Flat Dutch, it does not follow that it is so. He may have been deceived himself. No one can tell till valuable time and labor have been expended on the crop. No other commodity but drugs is so entirely a matter of confidence. It behooves every one to get their supplies from dealers of recognized repute, men who have a reputation at stake. Cheapness at once is sufficient to raise a doubt both as to vitality and quality. Good seeds have a valuethey cannot be cheap in the common acceptation of the word. The rather inelegant though expressive phrase, "cheap and nasty," applies to seeds more than to any other commodity.

895. Q. What is darnell ?

Darnell.

A. It is Cheat or Chess, a plant somewhat of the appearance of wheat, but never, as some people think, developing from wheat. Darnel is hardier than wheat, which sometimes when Winter killed is succeeded by darnell, and ignorant people think that the wheat has turned to darnell. Cheat whenever grown under a heavy crop of wheat never reaches over a few inches in height, and is not noticed, but when given a chance by the Winter killing of the wheat rises to a height of one to two feet.

896. Q. Will you furnish me a table showing the relative periods of Maturity of maturity of different sorts of peas?

Peas.

A. In our trial grounds the past season we tested 125 samples of peas from various sources, comprising nearly every variety at home and abroad of any note. Twenty feet of row was given to each trial. All were planted the same day, and upon equal conditions in every respect. The stocks of each were the best obtainable. Landreths' Extra Early were the first to bloom and first to ripen for the table, fifty days from sowing, or forty-seven days from germination. This variety has, under other conditions of heat and rainfall, ripened for table thirty.eight days from germination. It has been in cultivation by us for over sixty years, and has never been excelled in earliness or delicacy of flavor. All the Eng- 
lish varieties proved of deficient vitality, while the American stock again illustrated the fecundity of seeds ripened under our more tropical sun. We give below a report of our tests last Spring, the varieties classified in order of maturity :

Maturity of Peas.

\begin{tabular}{|c|c|c|c|c|}
\hline & VARIETIES. & sow's. & EDIBLE. & $\begin{array}{l}\text { No. OF } \\
\text { LiYSS. }\end{array}$ \\
\hline 1 & Landreths' Extra Early............... & April 25 & June 13 & 49 \\
\hline 2 & Alpha $\ldots \ldots \ldots \ldots \ldots \ldots \ldots \ldots \ldots \ldots$ & & " 15 & 51 \\
\hline 3 & 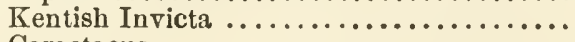 & “ & “ 16 & 52 \\
\hline 4 & Caractacus. $\ldots \ldots \ldots \ldots \ldots \ldots \ldots \ldots \ldots$ & “ & “ 18 & 54 \\
\hline 5 & 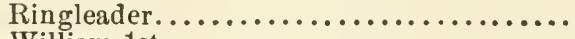 & “ & “ 18 & 54 \\
\hline 6 & William 1st $\ldots \ldots \ldots \ldots \ldots \ldots \ldots \ldots \ldots \ldots$ & “ & “ 18 & 54 \\
\hline 7 & Dickson's First and Best............. & " & “ 18 & 54 \\
\hline 8 & 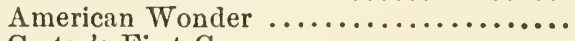 & “ & “ 19 & 55 \\
\hline 9 & Carter's First Crop.................. & " & “ 20 & 56 \\
\hline 10 & 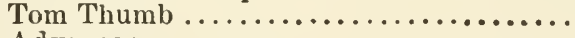 & " & “20 & 56 \\
\hline 11 & 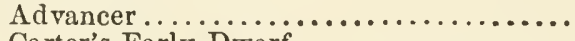 & “ & “ 22 & 58 \\
\hline 12 & Carter's Early Dwarf ................. & “ & “ 22 & 58 \\
\hline 13 & 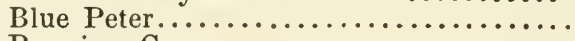 & " & " 23 & 59 \\
\hline 14 . & Premium Gem...$\ldots \ldots \ldots \ldots \ldots \ldots$ & " & “ 23 & 59 \\
\hline 15 & 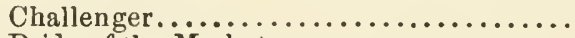 & “ & “ 23 & 59 \\
\hline 16 & Pride of the Market................... & “ & “ 25 & 61 \\
\hline 17 & 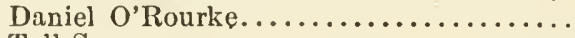 & ‘ & “ 25 & 61 \\
\hline 18 & Tall Sugar...$\ldots \ldots \ldots \ldots \ldots$. & “ & “ 25 & 61 \\
\hline 19 & Eugenie $\ldots \ldots \ldots \ldots \ldots \ldots \ldots \ldots \ldots$ & “ & “ 25 & 61 \\
\hline 20 & 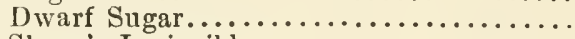 & “ & “ 25 & 61 \\
\hline 21 & 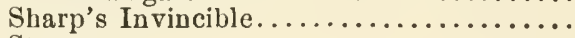 & “ & “ 26 & 62 \\
\hline 22 & Stratagem $\ldots \ldots \ldots \ldots \ldots \ldots \ldots \ldots \ldots$ & “ & “ 28 & 64 \\
\hline 23 & Bijou. $\ldots \ldots \ldots \ldots \ldots \ldots \ldots$ & “ & “ 29 & 65 \\
\hline 24 & 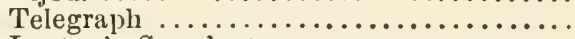 & “ & & 66 \\
\hline 25 & Laxton's Supplanter............. & “ & July 1 & 67 \\
\hline 26 & Sunrise $\ldots \ldots \ldots \ldots \ldots \ldots \ldots \ldots \ldots \ldots \ldots \ldots \ldots \ldots \ldots \ldots$ & “ & $\therefore$ & 67 \\
\hline 27 & Market Favorite.................... & “ & “ & 67 \\
\hline 28 & Fill-Basket $\ldots \ldots \ldots \ldots \ldots \ldots \ldots \ldots \ldots$ & “ & “ & 68 \\
\hline 29 & 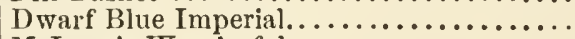 & “ & “ & 68 \\
\hline 30 & McLean's Wonderful ................... & “ & “ & 68 \\
\hline 31 & Forty-Fold $\ldots \ldots \ldots \ldots \ldots \ldots \ldots \ldots \ldots$ & “ & “ & 70 \\
\hline 32 & Champion...$\ldots \ldots \ldots \ldots \ldots \ldots \ldots \ldots \ldots \ldots$ & “ & “ & 70 \\
\hline 33 & 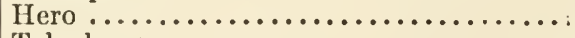 & “ & & 70 \\
\hline 34 & Telephone...$\ldots \ldots \ldots \ldots$. & “ & “ & 71 \\
\hline 35 & MeLean's Dwarf Prolific................. & “ & & 71 \\
\hline 36 & 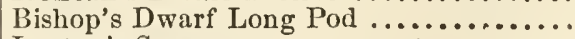 & “ & “ & 71 \\
\hline 37 & Laxton's Supreme .................... & " & “ & 71 \\
\hline 38 & Irish White Marrows.................. & “ & & 71 \\
\hline 39 & Veitch's Perfection................... & “" & " & 73 \\
\hline 40 & Dickson's Favorite $\ldots \ldots \ldots \ldots \ldots \ldots \ldots \ldots$ & “ & & 74 \\
\hline 41 & Black Eye $\ldots \ldots \ldots \ldots \ldots \ldots$ & “ & “ & 74 \\
\hline 42 & Culverwell's Giant Marrow .... & " & “ & 74 \\
\hline 43 & 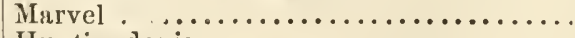 & “ & & 74 \\
\hline 44 & Huntingdonian...$\ldots \ldots \ldots \ldots$ & “ & “ & 74 \\
\hline 45 & John Bull. . . . . . . . . . . . & “ & “ 10 & 76 \\
\hline 46 & Veitch's British Queen............... & “ & “ 12 & 78 \\
\hline 47 & Emperor of Marrows ................ & “ & “ 14 & 80 \\
\hline
\end{tabular}


897. Q. Do the Landreths grow garden seeds on more than one farm? Landreth A. The Landreths court investigation-they have nothing to hide. Farms. No sced merchants in America cultivate upon their own lands, quarter as many acres annually as they do, in cabbage, turnip, Summer radish, Winter radish, beets, egg plants, kale, parsnip, pepper, spinach, tomato, onion sets, and seeds of many other families of vegetables.

The Landreth seed farms owned in fee simple by the firm are :

$$
\begin{array}{ll}
\text { I3loomsdale . . } 500 \text { acres. } & \text { Feedland . . 146 acres. } \\
\text { Monaskon ...222 acres. } & \text { Granville. . 472 acres. }
\end{array}
$$

And rented from the estate of David Landreth :

Georges . . 78 acres. Hunton's . . 185 acres. Bellemont . . 200 acres.

On these particular farms, in Summer, are sometimes employed a force of two hundred hands, and in harvest time the force is increased to four hundred and fifty hands.

898. Q. What is meant by Pedigree Seeds?

A. Strong believers in heredity endeavor to grow from seed of fixed Seeds.

habit. Intensely careful selections of many years have established types which are almost fixed, and are called "Pedigree Seeds."

Heredity is most fixed when plants are cultivated upon the soil and under the climatic surroundings of their place of origin, while on the other hand, very radical departures are made when the same plants are grown under changed conditions of soil and climate. This is noticed in the enlarged and coarse development of cabbage grown in Oregon or California from Pennsylvania seed, or in the deterioration of the edible qualities of watermelons grown in the South from New Jersey seed. Any Eastern seed taken to the Pacific slope will, in a few years, so depart from its original type as to be hardly recognizable under its original name. The most marked effect of soil and climate is on some of the regetables of Japan, many of which are products of Landreths' seed sent to Japan by the United States Patent Office on the occasion of the expedition of Commodore Perry to Japan in 1847. Those seeds were the first of the kind ever introduced into that empire. We have since received and tested many Japanese seeds of vegetables bearing what we have taken to be a trace of the original American parentage.

As respects heredity and the art of crossing two or more varieties whose superior qualities, if united, would be desirable, much has been accomplished, and in the future various astonishing results will, no doubt, be developed, for the number of hybridizers, all working out different lines, will certainly produce a multitude of interesting results. While the greater part, however, of so-called new sorts are the results of chance admixture in the field, the seed grower is now ceasing to be a mere plodderon in the steps of his ancestors, but is entering into his work physiologically, if not scientifically, and the work of the hybridizer is now so multiplying varieties and subvarieties as to confound the unintelligent seed planter. While the meritorious alone will stand the test and be per- 
Transplanting Trees.

petuated, other inferior subtypes will be offered under most extolled descriptions never to be heard of again. The best opportunities for hybrldizing are in the union of domestic plants with others of like nature from remote sections of the world, resulting in most striking development, and generally most healthful constitutional qualities.

899. Q. I have some evergreen trees to transplant. When can I do it best?

A. Trees holding their leaves all Winter, hence termed evergreens, are best planted in August and September; the earth then beneath the surface may be likened to a hotbed, so charged is it with heat, while the Autumn rains moisten the surface and stimulate root growth. Plants under these circumstances rapidly develop fibres which soon are able to compensate, by the moisture which they take up, for the evaporation by the leaves. The planting of such trees deferred till Spring often results in failurc, as the evaporation is then greater, and to an increasing extent as the Spring develops, while the soil is cold and root formation slow.

Testing Seeds 900 . Q. Do you test all your seeds for quality?

A. The Bloomsdale and Reedland testing grounds comprise various plots of over nine acres of land. One acre is devoted to vegetables grown from small seeds, as radish, lettuce, beet, carrot, onion; all sown in rows across the breadth of parallel beds eight feet wide with three feet alleys between. On these beds are many hundreds of tests.

Another acre is devoted to trials of peas and beans all drilled in par. allel rows, twenty feet of each variety, and all in the order of maturity as near as it can be arrived at. These peas and beans are thinned to three inches apart to permit perfect development, that the character may be indicated. Half an acre is devoted to sugar corn, planted in hills four by

Trial Grounds. four feet, and in parallel rows. These tests are also arranged in order of maturity ; the first early sorts many of them less than three feet high, the late varieties eiglit and nine feet high. $\Lambda \mathrm{n}$ acre is devoted to watermelons and cantaloupes, the testing and judging of which requires much experience. One-hali acre is devoted to squash. One-half acre to cucumber. One-half acre is devoted to cabbage. One-half acre to turnips. Two acres devoted to tomatoes. This last being of very particular interest, comprising many hybrids or crosses of approved varieties, the best qualities of several being united in one.

The test of insecticides being particularly interesting, more interesting than instruetive because of the conflicting results consequent upon conditions of rainfall and heat after the application of the poisons.

The test of ornamental flowers of annual and biennial form embellishing the whole with colors of dazzling beauty. The trial of grasses, all very practical; one bed of thirty different sorts in blocks of ten by ten feet, having stood for five years, clearly indicating the relative periods of desirability of eacl sort.

The seeds on trial in these experimental grounds comprise all the socalled novelties or varieties offered in the catalogues of the many seed 
mcrchants of the United States, as well also as those recommended by foreign seed merchants and growers as adapted to the American climate. Oftimes the same vegetable appears under half a dozen distinct names and as distinct descriptions, only to be recognized as an old acquaintance, sometimes of merit, at other times a sort long turned down. It is to inform ourselves upon the subject of relative merit and upon the subject of name that we conduct so large an experimental ground as nine acres, a very expensive little farm in itself, but worth ten times its cost.

901. Q. Give some information about the egg plant.

A. This seed is generally sown under glass and transplanted to the field two or three weeks after corn-planting season. The plants are set in rows of five feet and at three feet in the row. The land cannot be too highly fertilized for this crop- very short, thoroughly rotted stable manure or similar preparation is best; strong manure or hot, rank manure is unsuitable.

Sow in hotbeds or other protected place early in the Spring; when up two or three inches transplant into small pots (which plunge in earth) so as to get stocky well-rooted plants, and late in the Spring, or not till the commencement of Summer, unless the weather be warm, transplant into thoroughly worked, rich and recently well-manured ground. A good plan is to open a deep, wide trench, filling it nearly with manure; restore the earth and plant therein, placing the plants three feet apart each way. The seed does not vegetate freely; repeated sowings are sometimes necessary. It is almost useless to attempt the culture of egg plant unless the proper attention be given. In growing the egg plant in the Summer and Autumn months in Florida, great trouble is sometimes experienced in getting a stand of plants owing to the excessive heat and beating rains. This difficulty can be largely overcome by shading the ground where the seed is sown. If sown in beds, the shading may be accomplished by means of frames covered with seed-bed cloth, or by blinds of slats or common boards properly supported over the beds to cut off the direct rays of the sun. If the seed is sown where the plants are to remain (a bad practice) the shading may be done by using Palmetto fans or leaves, placing them one each on the north and south sides of the hill, the tops meeting over the seed. This plan is used by some of the most successful growers in the Gulf States.

About 3000 plants are required to plant an acre. These plants should produce an average of three to four fruits, weighing two to three pounds each. Our selected seeds are always taken from fruit weighing eight to ten pounds each ; we have had them of thirteen pounds in weight. Commission merchants in Philadelphia pay the market gardener about, on an average, one-and-a-half cents per fruit. The highest prices are eight and ten cents per fruit.

Florida fruit arrives in Philadelphia the latter part of November, and commands $\$ 6$ to $\$ 8$ per barrel crate. Earlier in the Autumn the market is supplied by fruit from Jersey. Towards Christmas the price of Florida 
egg plant rises to $\$ 10$ per barrel crate and then declines by A pril to $\$ 6$ to $\$ 8$, and by May to $\$ 5$, after which they are likely to arrive in a damaged condition and be worthless. Egg plant fruit can be grated and canned for Winter use.

Cooking Receipts.

Cooking Receipts.

902. Q. Please send me the directions for cooking garden vegetables published in your Catalogue of 1880 .

A. Asparagus-Steroed.-Wash, tie in bunches and place in saucepan of boiling water. Cook slowly until tender. Serve with butter sauce.

Cold.-After stewing as above directed, and when cold, serve with French dressing, or serve with Vinaigrette-sauce, made as follows : To French dressing add onions, pickles, parsley and capers, hashed and mixed well.

Beans-Green Beans, String-Stewed.-Wash and cut in half, and put in saucepan of boiling water, add salt, cook very quickly, drain through a colander and refresh with cold water to keep green; put in a frying-pan, add butter, salt, pepper and nutmeg.

Dried Beans-Stewed.-Soak over night in cold water; cook slowly with salt pork, add an onion, cloves, salt and pepper. When cooked thicken with melted butter and flour.

Baked.-Cook the beans as described above, add half gill of molasses; place in a deep dish with pork; bake in moderate oven for an hour.

Bean Soup.-Stew with a liam bone or pork; strain through a fine sieve; add a small quantity of cream and butter, and serve with fried bread crumbs.

BEETs-Boiled.-Wash, and boil till quite tender; rub off the skin, quarter and put into a saucepan, with salt, pepper, butter and a little broth. Let the butter melt, and mingle well by tossing the pan. Serve in a covered dish.

Pickled.-After boiling peel and quarter, refresh with cold water, cut in slices and put in a jar half full of vinegar; add salt, spices, slices of onion, whole pepper, a laurel leaf and horse radish cut in small pieces. Keep covered.

BroccolI-Boiled.-Boil in salt water until tender, and refreshing thoroughly put into a saucepan with light butter sauce, with salt, pepper and nutmeg. Place upon fire for a few moments and serve hot with a little chopped parsley. Cauliflower and brussels sprouts may be treated in the same manner.

Brussels Sprouts-Stewed.-Place in saucepan of boiling water, add salt, cook very quickly, put them in a colander and refresh with cold water, put in a frying-pan, add butter, salt, pepper and nutmeg. Serve hot with a garnish of chopped parsley. They can also be served with a light cream sauce.

CABBAGE-Boiled.-Carefully prepare and cut in quarters; put on the fire with plenty of water, and boil, refresh and cook either with ham, corn beef or salt pork. Cook slowly until tender and serve with meat.

Fried.-Use only fresh cabbage. Remove the outer green leaves, 
divide in quarters; cut out any hard core; wash carefully; parboil cooking twenty-five minutes, press the water out and cool. Cut in small pieces, Receipts. place in a saucepan and put in salt and pepper and fry to a light brown.

Pickled.-Cut raw cabbage very fine, add salt, pepper and mustard seed ald boiling vinegar with onion and green pepper cut very fine. Cover carefully.

Coleslaw. - Cut cabbage very fine, and serve with French dressing.

Sauer Kraut.-Use only solid heads shred very finely; take a small water-tight keg and line with cabbage leaves, sprinkling one-eighth of an inch salt upou the bottom; upon this place three inches of shredded cabbage, which cover with three tablespoonsful of salt well pressed down, then another layer of cabbage and salt, until keg is full, when hammer down with force. Small portions of herbs, chopped peppers and onions are often added. On top of the upper layer of cabbage place a circular head of less diameter than the keg, on which fix a heavy weight. When fermentation begins skim off the scum, keeping the cover always in place. To serve sauer kraut wash it well in warm water and drain thoroughly, garnish the elges of the dish with carrots, onions, a bouquet of herbs, some chicken or goose grease, and put the sauer kraut on top, adding salt pork, sausage, or piece of bacon in the middle ; add salt, pepper, a glass of white wine and a couple of apples cut very thin, a pint of broth, cover and let cook for two hours. Serve hot.

Cauliflower-Boiled. - Wash, place in a vessel with cold water and boil, empty, refresh, and boil again; when nearly done, drain and add a small quantity of milk and butter, and cook until tender. Serve hot with cream and butter sauce.

Au Gratin.-Boil as directed above. Place tablespoonful of butter in frying pan, when melted add teaspoonful of flour, mix thoroughly and add one-half pint of milk; stir continually until it boils, when add onehalf teaspoonful of salt and four tablespoonsful of grated cheese, Parmesan is best, pour this over the boiled cauliflower, sprinkle a little bread crumbs and bake in a moderate oven until light brown and serve hot.

Baked.-After cooking as described above, place the cauliflower in a baking dish, add salt, pepper, nutmeg, cream sauce, bread crumbs, and a litte grated Swiss or Parmesan cheese and small pieces of butter. Place in a hot oven and bake until it has a brown color.

Cold.-Cauliflower can also be served cold with French dressing.

Carrot-Stewed.-Peel and slice, put in a saucepan with a little broth, Cooking water, salt, pepper and nutmeg. Boil an hour. Thicken with butter Receipts. kneaded with flour, mix well and boil. Finish with butter, teaspoonful sugar and chopped parsley. Serve hot.

In Cream.-Wash and scrape the outside, cut in small pieces, boil until tender, refresh and boil again. Serve hot with cream sauce.

Celery-Sterced.-Trim off all defective parts and wash thoroughly. Parboil five minutes or until tender and drain through a cloth. Cut stems all same length and put in a stew-pan, with salt, pepper, butter, 
Cooking Receipts.

Cooking Receipts. and white broth to cover; let simmer for an lıour. Drain the celery through a sieve or cloth, saving the liquor, to which add Espagnole sauce. Skim the fat so as to form a sauce, press thoroughly through a napkin; place the celery on a dish and pour over the sauce.

Espagnole Sauce.-Take half pound clarified butter, add one pound flour ; roast very light brown. Add onions, carrots, a bonquet of herbs, allspice, a knuckle of veal and a ham bone. Let simmer slowly in saucepan, then moisten with three quarts of stock to a thin light sauce. Let cook for three hours slowly. Skim off the grease ; then strain the sauce, and reduce with sherry or white wine, according to taste.

Salad.-Use the hard roots as well as stems. After washing well cut the stems, both blanched and green, into small pieces. Serve with French or Mayonaise dressing.

Cons-Boiled.-Wash and boil in plenty of water with a small quantily of milk ; cook for twenty minutes.

Fritters.-Grate corn raw or cooked. For dressing take one pint of milk, four eggs, two teaspoonsful of baking powder, half pound of flour, salt, pepper, sugar, beat into light batter. Fry on both sides in pan with hot lard, one tablespoonful of batter to each fritter.

Pudding.-Place half pound of Indian meal in three pints of boiling milk lightly sugared. Cook for twenty minutes, add molasses, six raw eggs, and spices, mix well together. Put in a baking dish and bake in a moderate oven. Serve with vanilla or other flavored sauce.

Cucumbe1-Salad.-Peel and cut in very thin slices and soak in salt water for two hours. Strain till very dry. Serve with French dressing.

Sliced-Pickled.-Peel and slice fresh cucumbers and put in a pan and let stand with plenty of salt to draw the water. Press dry and put them in a jar, pour over cold boiled vinegar. Add salt, pepper and a few slices of onions.

EGG Plant-Fried.-Peel the fruit and cut crosswise in slices of full diameter and of one-third of an inch in thickness, sprinkle salt. between the slices and set aside for a half hour, when remove the water, dry and dip in butter and bread crumbs and fry in hot lard until brown.

Baked.-Peel the fruit and cut into small pieces. Place in a pan with butter and sweet oil over a fire for tliree minutes, add salt, pepper, and a little sauce or gravy. Take it from the pan and put in a baking dish, coat over with bread crumbs and Swiss cheese and bake in oven till quite brown.

KonL-RaBI-Boiled.-Remove the skin, cut in quarters. Boil in salted water with a little butter, drain, put in a saucepan with melted butter, stir a few moments over the fire and add Espagnole sauce with salt, pepper, butter; mix well and serve in a deep dish.

Mushrooms-Steroed.-Wash thoroughly, peel and cut off injured parts. Place in porcelain stewing pan with salt, pepper and butter, and two teaspoonsful of salt water, stew for eight minutes. Serve on toast.

Baked.-Clean thoroughly, remove the stems and fill the cavities with 
stufting composed of onion, tomato, parsley, chopped very fine. Add Cooking salt and pepper, put in a saucepan with butter, stew for twenty minutes. Receipts. Add crumbs of bread and thicken, fill the patties and spread crumbs upon the top. Bake in a moderate oven a few minutes and serve with brown sauce.

ONION-Steroed.-Remove the coarse skin, cut in slices and put in saucepan with fresh butter and let simmer until a light brown, add some Espagnole and a little Worcestershire sauce, salt and pepper. Cover and cook for twenty minutes.

Baked.-Select largest and most perfect onions and boil for an hour. Peel off outer portion and put each onion in a buttered stew pan with Espagnole sauce and brotlı; sprinkle a little sugar and put a small piece of butter on each onion. Place a buttered paper on the dish and bake in a moderate oven.

Fried.-Wash, cut in thin slices, dip in cream, add salt, pepper and roll in flour, fry in hot lard till crisp.

Okra-Boiled.-Wash and cook in cold water to a boil, refresh and cook again with boiling water till tender. Add butter and salt and serve with butter sauce.

Steroed.-Wash and cut off ends, place in stewing pan with a little water, boil until soft, drain, season and serve with melted butter.

Vegetable.-Cut the okra in small pieces, put in a pan with butter and sweet oil, and let it simmer for three minutes, add tomato sauce, salt, pepper and small pieces of butter.

Soup. - The okra for soup must be tender, which condition can only be found when the pods are small. To prepare okra soup cut chicken into small pieces, boil, refresh, add okra cut in small sections, rice and tomatoes. Continue boiling till the chicken is quite tender, season with pepper and salt.

PEAs-Boiled.-Cook in salted water over quick fire until tender, re-Cooking fresh, strain thoroughly, season with salt, pepper, butter and a little sugar. Receipts.

Soup.-Use split or fresh green peas, wash and put on fire with ham bone, add onions, carrots, knuckle of veal. When the meat is cooked remove it, and strain the soup through a fiue sieve, add small quantity of eream, butter, and season to taste. Serve with fried bread crumbs. Soup not to be too thick.

Parsip-Fried.-Boil until tender, remove skin, cut in slices, dip in butter, roll in bread crumbs, and fry dry in hot lard.

Sıute.-When boiled, cut in slices, place in frying pan with butter, salt, pepper and hashed parsley.

Puגprin-Pie.-Peel, cut in pieces and remove seeds, put over fire with water and cook until tender, mash or pass through a sieve, add powdered sugar, cream, allspice, nutmeg, six eggs, small quantity of brandy, teaspoonful cooking ginger, mix well, bake in moderate oveu with one layer of dough.

Potato-Boiled.-Wash and cook in salt water in pot with cover. 
Cooking Receipts.

When soft to the centre pour off all the water, and for ten minutes let the pot, without lid, stand on the range to get rid of moisture.

Croquettes.-Boil peeled potatoes in salted water and put thern in oven five minutes to dry. Turn them into a pan, add butter, salt, pepper and nutmeg, mash quickly, pass through a colander, return to the saucepan, adding four egg yolks; put on the fire for a few minutes. Turn into a dish and let cool ; divide into portions the size of an egg, roll in pulverized crackers, dip in batter of beaten eggs, roll in crackers again and fry to a brown color in plenty of lard.

Fried.-Peel and wash medium-sized potatoes, cut in one-eighths. Fry them in hot lard until cooked thoroughly and of a brown color. Drain, salt and dry in napkin before serving.

In Cream.-Take cold boiled potatoes, cut in small pieces, put in stewing pan with cream sauce, salt, pepper, nutmeg and butter, care being taken not to make the sauce too thick.

Lyonaise. - Cut cold boiled potatoes in thin slices, put in frying pan, add butter, thin sliced onions, salt and pepper. Fry until brown. Serve with chopped parsley.

Steroed.-Peel and slice cold boiled potatoes, put in a saucepan with milk, butter, salt, pepper and nutmeg, and let boil. Add parsley and butter and mingle all well by tossing the saucepan until the sauce is creamy. Serve hot.

SALsiry-In Cream.-Boil until tender, cut into thin slices, add cream, or butter sauce. Season to taste and garnish with chopped parsley.

Fried.-Trim and scrape the roots, boil until tender, drain on a cloth, cut the roots into pieces, one inch in length, dip in flour batter and fry crisp in very lot lard; drain, salt and serve hot.

Patties. - Trim and scrape the roots and boil in salted water whitened with flour; drain and let cool ; cut in small squares or dice and put the pieces in a good cream sauce, with salt, pepper and a little nutmeg. Let cook for two minutes. Next, fill the patties, bake brown, and serve hot garnished with parsley.

Imitation Oyster.-Trim and scrape the roots and boil until tender, in salted water whitened with flour; drain, and when cold mash, removing all fibres; add mashed potatoes and put in a stew pan with butter. Stir them over the fire until very dry. Add a little salt, pepper aud one or two yolks of eggs. Wheu cold, form in cakes shape of oysters, roll them in cracker dust or bread crumbs, then in a batter of eggs and bread crumbs. Fry in hot lard until brown on both sides, but not greasy. Serve hot.

Cooking Receipts.
Sea Kale-Stewed.-Pare the stalks, wash well and tie in bunches of even size. Stew for twenty minutes, or until tender, in salted water, thicken with flour kneaded with butter, drain on a cloth, untie, dish up with a buttered white sauce on a large napkin.

Squash-Stewed. - Peel and cut in quarter pieces, place in pot with little water, when cooked mash or pass through a sieve, add pepper, salt and butter, mix well and serve hot. 
Tomato-Steroed.-Scald with boiling water to remove skin, cut in Cooking small pieces, removing cores, place in stewing pan with butter, salt, Receipts. pepper, cook for a few minutes, thicken with corn starch, or bread crumbs.

Fried.-Cut in thick slices, season with salt and pepper, roll in flour, and fry with hot lard until brown on both sides. Serve hot.

Tounip-Boiled.-Peel and cut in small pieces, boil until tender, mash, add salt, pepper and butter, or serve in light cream sauce without being mashed.

903. Q. At what date were Garden Seeds first grown for sale in this Earliest country?

Seed Culture.

A. Possibly some were grown in colonial days, but there is no record in existence of such culture, everything being imported so far as known. The first recorded seed culture was by David Landreth, of Philadelphia, 1784, followed by John Mackejoln in 1792, by William Leeson in 1794, and by Bernard McMahon in 1799, all of Philadelphia.

904. Q. Which seeds of garden vegetables are richest in albuminoids? Albuminoids.

A. Peas and beans, vegetable casine being found in them to the extent of 20 to 30 per cent. In potatoes, vegetable albumen is found in large proportion, and in wheat, vegetable fibrin.

905. Q. What proof is there that diversified farming is the safest to Profitable pursue?

Farming.

A. The report of the United States census for 1890 shows that of the farms sold on foreclosure 98 per cent. were those devoted to one or two crops only, while on farms devoted to many crops only 2 per cent. were thus sold out.

906. Q. When planting cucumber seed and other seeds of vines, how vine Seeds. many should be planted in a hill and how many plants left to stand?

A. The average number planted is six or seven, but more is better. Farmers' boys use the following rhyme as to corn :

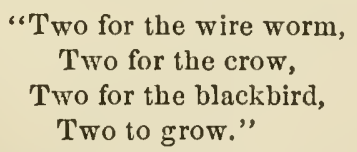

907. Q. I am thinking of laying out a lawn of about three to four acres Lawn. around my house, and inquire what should be the leading idea governing the plan?

A. As a rule lawns are planted without any artistic or practical plan, and you do well to contemplate laying out the work after a defined system. You will do still better to employ a landscape gardener to draw a plan just as you would employ an architect to design a house. The first thing is to decide on the number and directions of vistas or lanes of open views from the windows, doors or porticos, and then stake them out and positively adhere to keeping these vistas open. These vistas may be three or four or more, giving views of distant country, of hills, valleys, water or other pleas- 
ing objects, all displeasing objects being hidden by masses of evergreen trees and shrubs, which should be evergreen so as to hide the displeasing objects in Winter as well as in Summer. The spaces between the vistas to be planted with trees and shrubbery, single specimens and groups. On these spaces mark with stakes the position of trees intended to reach full devel. opment, placing them far enough apart to admit full development. This done, fill in the spaces with other trees to make an immediate effect, but to be cut out as rapidly as they encroach upon those intended for full development. Few men have the strength of character to thin out lawn trees encroaching upon each other, but those who do thin out from time to time have shapely trees and a general effect to be admired, while the timid souls have only a mass of shrubbery and trees, a constant advertisement of their incapacity.

American Seeds. Cabbage.

Tobacco.

Cotton Oil.

Onien Sets.

\section{Antumn}

908. Q. Is there any particular merit in the seeds of garden vegetables produced in the United States as compared with foreign seeds?

A. Yes; most assuredly. They are in the first place acclimated and enabled to withstand our hot suns, possessing an heredity fitting them to American conditions-not so with seeds developed in the moist climates of F'rance, England or Germany; and in the second place, American seeds are more vital, being ripened in a dry climate, ripened in the field and not in a stack as are most European seeds; and thirdly, American seeds are grown by the most intelligent of American farmers, men who know what other Americans want as to form and quality.

909. Q. What sorts of cabbage are most desirable for sowing in September to carry over Winter in cold frames?

A. Among Pointed Heads, Select Jersey Wakefield, Landreths' Large York and Bloomsdale Early Market. Among Flat Heads, Reedland Early Drumbead and Early Dwarf Flat Dutch.

Linseed Oil. 910. Q. What was the estimated value of linseed oil pressed in the United States during the census year of 1890 ?

A. Over twenty-three millions of dollars, the product of sixty-two establishments.

911. Q. Can you inform me the estimated value of the annual manufacture of tobacco, a very important agricultural product, into cigars and cigarettes, snuff, and smoking and chewing preparations?

A. About two hundred million dollars.

912. Q. Under the census report of 1890 , what was the value of cotton seed oil and cotton cake?

A. The value of the two was over nineteen million dollars, the product of one hundred and nineteen establishments.

913. Q. How is it that of the two lots of onion sets received from you, the first in September, and the other in December, the last were superior to the first?

A. Sets shipped early in September are not fully cured, consequently they cannot be expected when packed for several days, or perhaps for two or three weeks, in crates or barrels, to be secure against heating and rot. 
ting. Sets, no matter when received, especially if in early Autumn, should always be immediately unpacked and spread out on a dry floor to air, and all rotten ones picked out, as one damaged one will infect many others. Autumn-shipped sets should be planted early as possible after receipt to stop loss by decay, and to gain quantity of product through an early start.

914. Q. What is the matter with the musk melons this year? Every Musk Melons field, without respect to variety, is full of mixtures.

A. Your question answers itself. - It would be impossible for every sort in every field to have been grown from mixed seed. A general effect just as you describe is caused by a local condition of too much or too little rain, heat or sunshine, or by a general attack of insects or fungi.

915. Q. About White Grocery beans. How are they grown and har-Beans. vested?

A. Any ordinarily good soil will grow beans if not subject to overflow. They, however, do best on a clover sod, supplemented by 400 or 500 pounds per acre of good fertilizer. They can be sown by any ordinary grain drill, every fourth tube feeding, or can be drilled by a bean driller, which costs about $\$ 40$. They must be cultivated and kept clear of weeds. The vines can be pulled by hand or podded by a bean harvester. They can be thrashed by a flail or by a grain thrasher. The production varies from ten to twenty bushels, and the price, to the farmer, varies from $\$ 1.30$ to $\$ 2.00$ per bushel.

916. Q. You wrote that the plant referred to in our letter was an Adventurous adventurous plant. What do you mean by that?

Plant.

A. Those which by accident become established in new regions. As a rule but few survive in the uncultivated condition more than three or four years. For example, after the Centennial Exhibition held in Philadelphia, in 1876, quite 300 new plants were observed growing in Fairmount Park, disseminated by seeds brought from various parts of the world in the straw and hay used in the packing of foreign goods, but now they have all disappeared. It is the same with insects, many new forms were observed for several years subsequent to the fixhibition, but now they have all disappeared.

917. Q. Do vegetables cultivated for their roots, as carrots, beets or Growth turnips, make a root development immediately upon starting into growth of Roots. or later on in their existence?

A. Only after complete establishment. All dicotyledonous plants have at first a single descending axis called a tap-root, and this must establish itself as a growing organism, rooted in the earth, and drawing nourish. ment from the soil and through its attached foliage, before it begins to lay up any superfluous tissue. Tap-roots are anchors, and the places of origin of minute subterranean filaments or feeders. The swelling out of tap-roots by the laying on of tissue is a development subsequent to a complete formation of plant existence. For example: Take a very young Scarlet Turnip radish and a very young Long Scarlet radish, and the first 
has as long a root as the other, or take a Long Blood beet and a Red Turnip beet, and the young turnip form has a root fully as slim and long as the Long Blood, and sometimes under peculiar weather conditions they are both slow to lay up tissue and seem to be of similar habit. Just the same with turnips, flat sorts sometimes seeming to be going to make long roots. A peculiarity of the tap-roots is that it is only the point or termi. nal which extends, that is, the lengthening al ways being a continued extension of the newly formed point, consequently a tap-root never extends after the point is cut off. The edible portions of the roots of beets, carrots and turnips are really the upper part of the tap-roots, and while naturally distended beyond other parts have been abnormally developed by hundreds of years' selection.

Warranted Seeds.

\section{Cane Sugar.}

Agricultural Implements.

Egg Plant Vitality.
918. Q. Do you warrant your seeds?

A. No; we are not so foolish as to warrant as correct the results which may be developed consequent upon all sorts of mismanagement of a crop. All seed merchants have too many complaints of disappointments of crops due to unfavorable soil and atmospheric conditions, and due to ridiculously bad management and want of common sense, to warrant satisfactory results.

919. Q. How many pounds of cane sugar were produced in the United States during the census year of 1890 ?

A. 301,284,000 pounds of sugar, and of cane molasses, 25,409,000 gallons. The value of the sugar refined in the United States the same year was one hundred and twenty-three millions of dollars.

920. Q. What is the value of the annual manufacture of agricultural implements in the United States?

A Over eighty-one millions of dollars.

921. Q. I ask if you will pardon my hasty and perhaps testy complaint that the egg plant seed you sold me was unvital, for I have sprouted it as you suggested and find it all right?

A. Certainly. We are pretty well broken in to groundless complaints, as not only the planter of seed but the merehant finds it easier to write a testy letter than to take the trouble to investigate. Your complaint is only a repetition of hundreds just as groundless.

The most common experience in the way of foolish complaints, is the claim so often unreasonably made that one of a number of varieties of seed failed to develop as perfectly as on some previous occasion, the com. plainant forgetting to award praise for the ninety and nine varieties which gave satisfactory results. The gardeners expecting a venture in seeds to be far more certain than any other business speculation, notwithstanding that the influences bearing upon germination, plant nutrition, climatic and physical conditions are beyond their knowledge and control. It is the unreasonable claim of inexperienced and ignorant persons that if seeds do not grow when put into the ground it is always because they are bad. Now, this is a silly charge, for good seeds may in whole or part fail to grow for very many reasons or causes; as, for instance, improper or in- 
sufficient preparation of the ground, unseasonable time of sowing, sowing too deep or too shallow, insufficient moisture, excess of moisture, cold, heat, depredations of insects under or above the surface, unfavorable conditions of climate or atmosphere, deficiency or excess of natural forces which we do not understand.

The writer has been called upon to view hundreds of poor crops which Complaints the gardeners have claimed to be due to the sowing of unvital seed, but of vitality. generally he has been able to point out to the gardeners extended pieces here and there where the germination had been perfect, proving that the failure in other portions was due to imperfect preparation of land or bad sowing, as respects time or depth of covering, for if the seed had a vitality of eighty or ninety per cent. over one foot in a hundred feet of row, it was equally vital all over the patch. Another class of complaints are from those who attempt to assure the seed merchant that every one of a number of varieties of seeds sold were of bad vitality. These unreasonable people lay down the charge most emphatically, forgetting that such a wholesale condemnation contradicts itself, for no seed merchaut who ever filled an order would send out seeds all of which were unvital; he might make a mistake with one, but not with all. It is clearly obvious that when all the seeds of an entire purchase vegetate indifferently or entirely fail, the fault is in the preparation of the land, the sowing, the soil, insects or the season.

The seed merchant is frequently berated by a certain unreasoning class of gardeners who lay all the blame of various failures of the seed upon him, and when, on the other hand, tìe crops develop to unusual proportions by reason of favorable conditions, the same class of gardeners want a premium from the seed merchant for growing the best in their district. No class of purchasers are so unreasonable as seed purchasers, for they look for perfection in an article yet unborn. The cattle breeder knows full well that young stock does not always turn out as he desires, plan he never so wisely as to cross-breeding.

The seed merchant often receives complaint that a lot of cheap seeds purchased at random gave as good results as a more costly article, the complainant forgetting that he cannot rely upon cheap seeds, for the following year they may be villainously bad.

The gardener cannot manufacture vegetables or flowers, nor the farmer grain or potatoes, as the mechanic makes an engine, or a shoemaker a boot. The gardener has to trust to the hidden processes of nature as developed by moisture, heat, chemical action and nutrition. He can only help nature, and ofttimes is powerless to do that ; and when some natural action fails, or he sows or transplants at an unseasonable period, he should not lay the blame upon the seed merchant, unless well assured that the seeds sold are positively unvital or positively untrue as to representation of kind.

922. Q. What is the difference between corns known as Gourd Seed, Corn. Dent and Flint? 
A. The Gourd Seed has starchy matter covering the entire top or crown of the grain, the bony and oily sides of the grain not extending up as high as in the Dent nor entirely up to the top as in the Flint. This starch of the Gourd Seed when the grain becomes hard and dry shrinks down, leaving the top portion of the skin or cuticle of the soft grain to dry and curl, which it does, in the form of a sharp or rough tooth-like projection, something like the end of a seed of a gourd or squash.

Dent corn has less starch on the crown of the grain, and the horny or oily sides extending almost to the top, the small amount of starch on the crown when shrinking seems to draw down with it the skin or cuticle, forming a depression or dent, hence the name applied to this type of corn.

The Flint corns, like the Pop, have the horny or oily sides running clear over the top; they possess little starch and consequently there is no shrinkage as in the others to cause a collapse, as it were, of the skin or cuticle.

Manure.

923. Q. Can I purchase everything which vegetable crops require as food?

A. Yes; so far as can be determined by the analytical chemist and vegetable physiologist, but you cannot get the component parts in just that condition in which they are most assimilable. There are unknown soil influences always at work, influences of heat, of cold, moisture, light, decomposition, combinations all the while changing the character of sub-, stance natural to or applied to the soil, and fitting or unfiting them as plant food.

Swede. 924. Q. Are the leaves of the Bloomsdale Swede the same as those of table turnips?

A. No; the foliage of a Swede turnip is smootl, a blue green, and glossy like that of a cabbage, while the leaves of table turnips and some round cattle turnips, both white and yellow fleshed, are yellowish green, rough and fuzzy. These are styled rough-leaved turnips, while the Swedes are spoken of as smooth-leaved turnips.

Pig Food. 925. Q. As you advise market gardeners remote from stable-manure supplies to keep pigs to make manure, I ask in what way does pig food differ from cow food?

A. The food for horn-cattle or sheep, ruminant animals, consists largely of grass, hay, straw, roots, all containing considerable woody fibres. Pigs want very little of foods containing indigestible woody fibre. They require fooòs largely composed of grain, or other seeds, seed oil-cake, tubers, all containing starch, sugar and nitrogenous matter, all very concentrated and digestible substances. Nevertheless the pig is a ravenous eater and consumes a much larger proportion of dry substances, compared with his weight, than the ox or sheep. The investigation of Dr. Lawes shows that for each 100 pounds of live weight per week, the fattening ox consumes over 12 pounds of dry substance, yielding $1 \frac{13}{100}$ pounds of increase; the sheep consumes 16 pounds of dry substance and yields $1 \frac{75}{100}$ 
pounds of increase, while the pig will consume 29 pounds of dry substance and yields $6 \frac{45}{100}$ pounds of increase.

Dr. Gilbert says the fattening foods are more valuable in proportion to their richness in digestible and available non-nitrogenous constituents, but as the manure is most valuable when it contains a large proportion of nitrogen there is an advantage in giving food rich in nitrogen even though it may not be so fattening.

926. Q. What are slime molds?

Slime Molds.

A. The lowest order of fungi, consisting of a mass of slime growing usually on other vegetable matter, as on leaves or wood, often on the roots of cultivated plants. The study of the subject of root parasites in general is being given great attention, for it is being discovered they are nearly quite as common as leaf parasites.

927. Q. Is Clover liay, according to its analysis, more valuable than Clover Hay. Timothy hay?

A. Most certainly. It is quite 25 per cent. more valuable, ton for ton. It contains twice as much nitrogen as Timothy, and nitrogen is worth fifteen to twenty cents a pound. Grow Clover hay yourself and you will not need to raise or purchase so much oil calke for feeding. The estimated average quantity of nitrogen in hay of Timothy is about 5 per cent., in Crimson Clover about 10 per cent, and in Cow Pea straw about 16 per cent.

928. Q. Can land be cropped continuously, and the product kept up, Fertilizer. on su perphosphates of lime?

A. It might, but the practice would be without reason. All crops require slightly different food and some very distinctly different, consequently an answer to your inquiry depends upon the crops you would purpose to grow. A continuous series of crops might be grown from superphosphates, but what would be the advantage in thus adhering to one fertilizer. It would be impractical and probably unprofitable.

929. Is it true that some plants poison the land so that others cannot Poisoned grow?

A. Dr. Lawes says that it is so, after fifty years' close attention to the subject. He denies that there are any injurious or poisonous excretions.

930. Q. Will you draw out a list of fruits arranged in the order of their Fruits ripening?

A. Yes; but the list can only be of such as are found most suitable in this section of eastern Pennsylvania.

Of Apples as follows :

Early.-Bachelor's Blush, Hagloe, Rose, Early Harvest, Yellow Trampat, Red June, Astrachan, Summer Pearmain.

Intermediate._Smoke House, Maiden's Blush, Gravenstein, Tall Pippin, Orange Pippin.

Late.-Fallawater, Ben Davis, Northern Spy, Smith's Cider, Baldwin, York Improved. 
Fraits in Order of Maturity.

Of Pears as follows :

Early.-Bartlett, Doyenne D'Ete.

Intermediate.-D'Anjou, LeConte, Bossouck, Sickel, Angouleme.

Late.-Lawrence, Rutter, Keiffer, Clairgeau, Sheldon.

Of Peaches as follows:

Early.-Mountain Rose, Amsden, June, Rivers, Crawford's Early.

Intermediate.-Stump the World, Old Mixon, Alexander, Reeves, Favorite.

Late.-Crawford's Late, Wonderful, Ward's Late, Lemon Cling, Freeman's Late, Heath Cling, Foster, Susquehanna.

Of Strawberries as follows :

Early._Bubach, Crescent Seedling, Jessie, Wilson.

Intermediate.-Sharpless, Charleston.

Late.-Gandy, Kentucky, Mt. Vernon.

Of Raspberries as follows:

Early.-Turner, Black, Doolittle and Rancocas.

Intermediate.-Souhegan, Marlboro, Cuthburt.

Late.-Gregg, Surprise.

Of Grapes as follows :

Early.-Noore's Early, Champion, Wyoming Red, Victor, Early Har. vest.

Intermediate.-Worden, Concord, Empire State, Delaware.

Late.-Highland, Pocklington, Salem, Wilder and Niagara.

Of Blackberries as follows :

Early.-Kittatinnery, Lawson, Wilson, Jr.

Intermediate.-Snyder.

Late.-Taylor.

Of Cherries as follows :

Early.-Mazzards, Hearts.

Intermediate.-Biggareaus.

Late.-Morelloes.

Nitrogen. 931. Q. How much nitrogen do crops take from the soil ?

A. They differ ; but in a general way, according to Dr. Lawes, cropping under an average rotation takes about 150 pounds each year, and about that much more is lost by leeching down to the substrata. Dr. Lawes estimates that about 300 pounds a year has thus to he obtained from some source or other.

Rotation of 932. Q. Who first advocated the a gricultural system of crop rotation?

Crops.

A. Lord Townshend, in 1730, saw the s5stem practiced in Germany, and introduced it upon his Norfolk estate, a rotation of turnips, barley, clover and wheat, raising his farm land from a sandy waste to great productiveness and value.

933. Q. What has been the increase of late years in the acreage of Wheat. wheat production in the United States?

A. In 1872 the area was twenty-one million acres, in 1876 twenty-eight million acres, and in 1892 thirty-eight million acres. 
934. Q. When was it discovered that certain crops enriched the soil ? Green

A. It was known in the days of the Romans. Varo, who lived 2000 Manuring. years ago, wrote "certain things are to be sown, not with the hope of very immediate profit being derived from them, but with a view to the following year, because, being plowed in and then left in the ground, they render the soil afterwards more fruitful." People of that day did not know or even theorize on the reason, but simply worked from the results of experience. The crops used by the Romans for this purpose was lupins and vetches.

935. Q. Will you give me the relative customs rates on agricultural Tariff produce under the two Tariff Bills, IIcKinley and Wilson?

Rates.

A. Yes; the small figures on the following schedule are the percentages on the obsolete McKinley Bill, and the large black figures are the present Wilson Bill?

\begin{tabular}{|c|c|c|}
\hline & WILSON BILL. & M'KINLEY BILL. \\
\hline 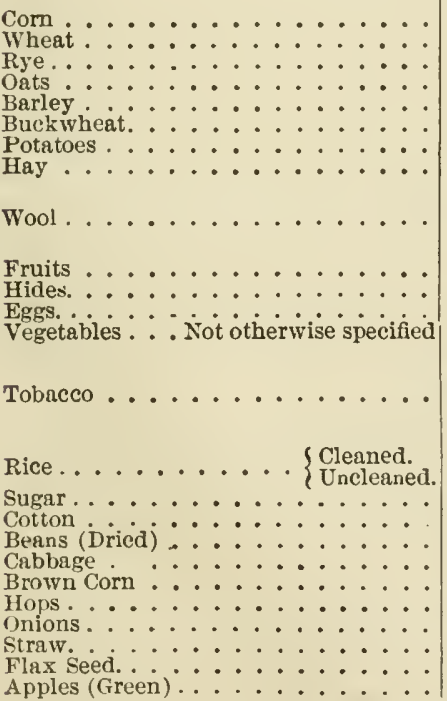 & 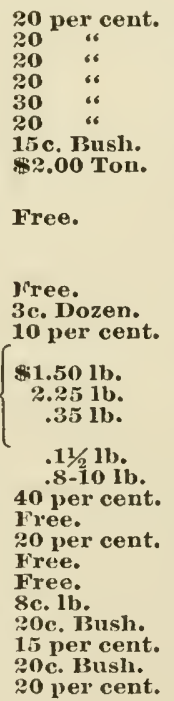 & 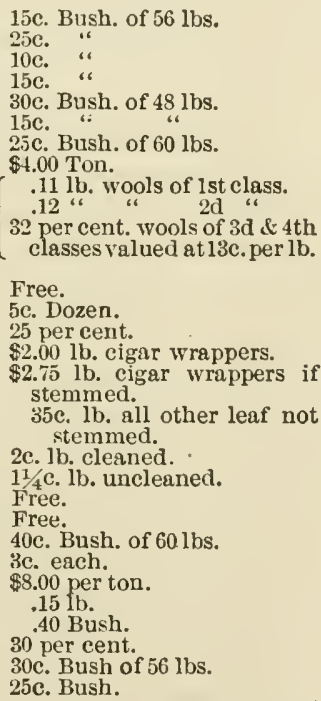 \\
\hline
\end{tabular}

936. Q. Will soils, however manured, refuse to produce continuous and Crop-sick oft.repeated crops of the same plant?

A. Yes; this is especially the case with leguminous crops, but Dr. Lawes for forty years has produced excellent crops of barley on the same land, and an average crop of thirteen bushels of wheat for the same forty years. 
Resistant Grass.

Origin of Narly Corn.

The Locust.

Shallots.

Onion Seed Sowing.
937. Q. I am Secretary of our State Fair Association and want to put down twenty acres in permanent grass within the grounds. What do you recommend?

A. That combination of grass seeds known as Landreths' Mixture for Athletic Grounds, it being composed of grasses which will resist tramping.

938. Q. Are the extra early varieties of corn of northern or southern origin?

A. Everything in their habit points to a southern origin. They no doubt were developed by persistent planting of early-harvested or halfripened seed. Plants of Southern habit do not shoot into growth so early in the Spring relatively as Northern plants of the same genera. The Southern plants not being so quick to respoud to small elevations of temperature. The long season of Southern latitudes develop'an heredity of long drawn out growth, while the quick, sharp, well-defined seasons of the North shorten the periods of growth. Southern plants removed to the North and brought under the influences of Northern seasons thus become earlier to sprout, quicker to grow and earlier to mature.

939. Q. How does the singing locust make its noise?

A. In the old Middle States no Summer insect, except the mosquito, is more in evidence than the Cicadæ or dog-day locust, its song being continuous from sunrise to sunset, consequent upon taking up of the refrain by one insect as soon as dropped by another. The song is an accompaniment of hot weather. The insect does not make its noise through its mouth, but by the action of powerful muscles upon drums located upon its body and abdomen. It may be often noticed the song of the locust is suddenly terminated by a discordant note ; this is caused by the attack and sting of the locust wasp--its deadly enemy-a great hornet which lives in holes in the ground into which it takes the dead locusts.

940. Q. Are there two types of shallots?

A. Yes. There is the true shallot, the oblong bulbs of which are generally encased in a silvery, filmy envelope and there is the false shallot, the bulbs of which are not so encased and which are less oblong, quite oval, sometimes nearly round, very solid and a coppery red, the outer skins very delicate and easily torn off.

941. Q. At what time should onion seed be sown in the latitude of Washington or south of it to produce early market onions for shipping in the Spring?

A. Sow the seed in a seed-bed between August 15 and September 1 and when the young plants are three inches ligh transplant them. In the removal from the seed-bed, the first operation is to loosen the earth beneath them so as not to tear off any of the root fibres. In setting the seedlings, place them in rows at eighteen inches apart and two or three inches apart in the rows. The scedlings should only be put into good soil, should be well fastened in, and the operation performed immediately after a rain. 
942. Q. I have just purchased a farm in Delaware and upon it find a weeds. varied assortment of weeds, which have for years held such undisputed possession that they seem to resist my efforts to eradicate them. What shall I do?

A. You must decide to become master of the situation, and the first thing to do is to study the habits of weeds. Their seeds are so often so thoroughly protected by envelopes of oily and starchy matter as to retain their vitality for years; some seeds freely sprouting when brought to the surface after having lain for ten or twenty years following an unusually deep plowing down, consequently the first important thing is to prevent the ripening of weed seeds by destroying the growing weeds, if not as soon as they sprout, certainly before they mature. This can be done at various stages by the hoe, cultivator, plow, or by digging out. A good plan to prevent weeds is to keep the land well covered with strong growing crops which themselves take full possession of the soil, as clover, rye and other top-heavy crops. A third good course is always to plow the land after a crop is removed and sow it in something to temporarily occupy the soil, if it only be a crop of broadcasted corn which may reach a foot or two in height. A good farmer will soon put a new face on any farm, be it ever so weedy, and no implement is so effective as the hoe, and by it weeds can be destroyed in their earlier stages; but that eminent agriculturist, Sir Joseph H. Gilbert, says, that upon visiting America he was told that no true-blooded American would bend his back sufficiently to use a hoe.

943. Q. How is it that I now find so many new weeds upon my Mary-Weeds, land farm which were not known in that section during my boyhood How days?

Disseminated

A. Because the seeds of wheat, oats, grass and clover are now frequently the product of distant localities and with them come the weed seeds of those remote sections. Seeds are often brought on the wool or hair of live stock. For instance : A herd of Texas cattle might easily introduce upon a Maryland farm a lot of weeds never before seen there; and in the bedding of cattle cars from distant western localities are brought the seeds of many weeds. The whole line of the Pennsylvania Railroad between Philadelphia and New York is now bordered with a prairie grass the like of which was not seen twenty years ago.

944. Q. Can I grow in Florida the new tanning plant Canaigre?

A. Yes. You can do it suceessfully in any loose and dry land south of the latitude of Jacksonville. The plant is a native of Mexico, Arizona and Southern California and belongs to the Dock family. It produces tuber-like roots weighing from a few ounces to several pounds; the clusters sometimes weighing up to one hundred pounds. It is propagated by the sets, about seven hundred pounds being required to plant an acre. The planting is best done between the 1st of September and the 1st of November. A crop is estimated to range from forty to fifty tons to the acre. 
Peanuts.

945. Q. What is the annual production of peanuts in the United States?

A. About four million bushels of twenty-two pounds each. For these the consumers pay $\$ 10,000,000$ annually. Virginia, Georgia, Tennessee and North Carolina are the largest producers in the order named. The African and Indian crop is over eighteen million bushels. Most of the foreign product is used in making oil, the kernels yielding from 30 to 40 per cent. of oil, worth at Marseilles about seventy-five cents per gallon.

The cake from the oil presses in countries where it is pressed is worth thirty dollars per ton as a food for cattle and pigs, and is considered superior to any other form of oil cake.

Source of

946. Q. Is the agricultural chemist a better farmer than the practical Agricultural field operator, or upon whose advice can I place the most reliance?

Advice.

A. The agricultural chemist's observations into the components of plants may be perfectly accurate, and if he was infallible as respects his conclusions then iudeed agriculture would be a science, and the chemist could direct the farmer just how crops should be fed, but plants are not entirely developed by chemical combinations or by mechanical measures, for back of all these is a vital principle or force, an irritability and variability and selective capacity which man cannot control or fathom. The agricultural chemist can only suggest foods from which plants can draw according to their powers of selection, advanced or retarded by vital force.

Asparagus. 947 . Q. When sowing asparagus seed in my garden what course shall I adopt to hasten its sprouting?

A. Soak the seed for a night in tepid water, the temperature not exceeding $130^{\circ} \mathrm{F}$. In the morning thoroughly mix the seed with damp earth, and put the mass into a box or barrel, where let it stand till minute white sprouts appear on the asparagus seed, when at once sow it in rows at ten inches apart, if to produce plants for transplanting, or if to remain permanently, sow it in rows at five or six feet apart. It is far best to sow in close rows, the young plants when two years old to be removed to permanent, locations.

Sugar Corn. 948. Q. Which varieties of Sugar corn most rapidly pass beyond the edible condition, that is to say, harden the most quickly?

A. The eight-rowed sorts remain the least time in edible condition, as the grains are not compact on the cob. Such loosely covered cobsquickly lose their moisture, and the grains their juice and palatability because of the extraction of their moisture in the drying of the cob.

Beet Sugar. 949. Q. What is the annual product of beet sugar in Europe?

A. In 1894-'95 the estimate was as follows: Germany, 1850 thousand tons; Austria, 1050 thousand tons ; France, 790 thousand tons ; Russia, 620 thousand tons ; Belgium, 285 thousand tons; Holland, 90 thousand tons ; other countries, 106 thousand tons ; a total of 4846 thousands. In the United States the approximate manufacture for 1894-'95 was 267 thousand tons.

Tomato.

950. Q. How long will a tomato continue to live and produce fruit if protected from cold temperature? 
A. Near the equator a tomato is said to live for many years like the grapevine In this latitude there lave been thousands of instances where in glass houses tomato vines have been kept in bearing condition for several years.

951. Q. Is salt good for land, and if so, why? Salt.

A. It is not strictly a manure, but changes cxisting conditions and may therefore be looked upon as an alterative. It also drives worms and in. sects, and by its affinity for water keeps land moist.

952. Q. Is Carolina phosphate rock a good dependence upon which to Carolina make a crop of garden truck?

Rock.

A. No, it is not. It is little better than a make-weight, or a component of a manufactured Fertilizer, reinforced by the addition of better materials.

953. Q. Three weeks ago I drilled my spinach seed, but by reason of Spinach Seed drought not a seed has sprouted. Will it grow when there is rain?

A. Probably it will if the heat of the sun during the drought was not sufficient to bake the seed. If the seed made an effort to grow and was arrested by the drought it will not start again as wheat would do, for spinach does not possess that quality.

954. Q. Does a thickly broadcasted corn crop collect nitrogen?

A. Certainly, it obtains a little from the soil ; but neither the leaves of corn nor the roots collect it from the air in the same quantity as do plants of the clover, bean, or pea family.

955. Q. Which is the most important fertilizer on a wheat farm?

A. Phosphoric acid, as the cereal crops draw largely upon it, and as it Acid. is stored away in the grain which is generally sold off the farm, consequently the drain upon the land is severe, and the phosphoric acid has to be replaced by artificial application. Potash is taken up by grain crops also, but the potash goes back to the soil in the form of straw, so also in the case of clover, beans, roots, fed upon the farm, the potash goes back to a large extent.

956. Q. Are Savoy cabbages superior to smooth-leaved sorts?

A. They are incomparably better, in fact almost equal to cauliflower, Cabbage. and they can be grown where neither cauliflower nor broccoli can be produced. They can be grown on any cabbage soii.

957. Q. Down here in Florida I have great difficulty in obtaining a Egg Plant, good stand of egg plants. What do you advise?

A. Advise the adoption of the Northern system of growing egg plants. How to In' Jersey a market gardener sows his egg plants in a hotbed with plenty of bottom heat and gives the bed every attention experience can dictate; plenty of heat, rich soil, sufficient watering, sufficient air under the glass at proper times, and he thinks well if he gets 50 per cent. of the best seed to stand, and only by greatest attention does he keep them free from fungous attack, for if mold once strikes them then he has no recourse. But in Florida the general system is to plant the seed in the open field, often in nearly white sand, generally without any protection from the sun. How can much success be looked for under such a system? 
Lime.

958. Q. Is lime found in plants, and what benefit is it to plants?

A. It is found in the straw of grain and more largely in straw of clover and beans. The two last are very obviously benefited by the application of lime. Dr. Gilbert thinks it is connected with the accumulative or vegetative processes of plants rather than with their maturing processes or condition, as a largely increased accumulation of lime is coincident with an increased bean and clover crop. Lime is therefore of much importance to all crops, but especially to the leguminous. Many soils, however, possess enough natural lime without any artificial application.

Ruta 13aga. 959. Q. Why is the ruta baga considered a better feeding root than White or Yellow Globe turnip?

A. Ruta baga turnips or Swedes do not develop such a mass of leaf as do White Globe turnips, though the Swedes give the greater weight of roots, by far the larger part of the accumulation of vegetable matter being in the roots. The measure of the value of roots is not in the weight of water but in the weight of dry substance, and in Swedes the dry substance surpasses the proportion in Globe turnips, consequently the Swede is the best feeding root. The Swede is not cultivated as largely as it should be because it requires earlier sowing than round turnips, and as at the proper season for drilling Swedes suitable land is not always available under American systems of rotation, or under the no system so common. Globe turnips planted later are more easily located on the farm, as they may follow a grain crop, while Swedes have to be sown before the grain is harvested. In any case it is not desirable to have roots too ripe, as they will not keep so well through Winter and into Spring.

Turnips or Beets.

Varieties of Turuips.

Roots for Cows.

Sagar 13eets. 960 . Q. What are the strongest rooting plants, turnips or beets?

A. The Sngar beet is a stronger rooter than the mangel, and both are stronger than the turnip. The Sugar beet, a strong feeder, has widely reaching and deeply penetrating roots, and absorbs freely, and lays up a large amount of sugar, sometimes one-fifth part of its crude weight.

961. Q. Do White Globe turnips and Swedes require different soils ?

A. They do not absolutely require distinct soils, but upon light soiis, which do not produce much leaf matter, Swedes will do well where Large White Globe turnips wouid fail, and on heavy land where Large White Globe turnips will flourish, sometimes Swedes will be disappointing. A too generous nitrogenous manuring for turnips of any kind induces a disposition to make leaf, sometimes to the disadvantage of the root product. Leafy roots are slow to ripen, bnt sometimes this is an advantage as roots too ripe do not keep well during Winter.

962. Q. Are roots a desirable food to give milking cows?

A. Yes; they are like grass, they increase the quantity of the milk; mangels to a greater extent than turnips, and Sugar beets more than mangels. Mangels are better in this respect than silage. Milking cows require more and richer food than animals being fattened for market.

963. Q. Can I rely upon a crop of Sugar beets as a regular and continuous cattle food? 
A. No; cattle should have other food rich in nitrogenous substance. The sugar or carbohydrates in roots renders them very valuable to cattle for making meat and milk, but they are not sufficient in themselves to sustain the animal functions. Starchy foods are wanted as well.

964. Q. Is there a difference in the processes of growing turnip beets or Growing other roots for cattlc feed and for seed purposes?

Roots.

A. Some distinction, as in the case of roots for cattle the effort is to develop the largest growth of the root and consequently the heaviest yield to the acre. This is only accomplished by giving the crops the benefit of the longest possible growing season. Early drilling is therefore a necessity in the case of cattle roots, but not so when growing roots for seed as then it is not desirable to have them too big or ripe, for such do not keep so easily as less mature roots. The second season, when seed is the object, it is best to plant out turnips and beets on heavier lands than that on which the roots were produced.

965. Q. Why is it that farmyard manure is so efficient?

A. The immediate or first active part of farmyard manure is the urine Manure. or liquid portion of the application, then afterwards the very fine and easily solved atoms of the mass, and then following the other parts in the order of their condition. Various lots of farmyard manure are hardly ever alike, never the same on distinct farms, seldom the same at different periods out of the same yard, consequently their action is more or less active and more or less constant. In all cases there are parts not availablc for two or three years and this is clearly proven by the long afterresults of an application of farmyard manure. In the processes of good farming, stable or yard manure is largely made, carefully saved, and judiciously applied, and as it is quite continuous in its actions, the fertility of a well-managed farm is constantly increasing.

966. Q. Which are the finest types of sugar corn?

A. Those of twelve or more rows, as in them are found the narrowest grains and tightest packing on the cob. With a diminution in the breadth of the grains there is an increase in sugary qualities-long, narrow shoepeg grains being generally the sweetest.

967. Q. How many years ago was introduced the system of preserving Silos. cattle foods in silos?

$\Lambda$. Eighteen hundred years ago, Cæesar practiced it when he made his march from Italy to Germany, storing in pits as he passed through the country large quantities of green fodder to serve as food for his animals upon his return march.

968. Q. How can I dissolve five hundred pounds of bones?

A. Break them up into pieces small as a walnut and mix with an equal quantity of wood ashes, also with thirty pounds of slacked lime, and tifteen pounds of sal soda made fine. Mix the mass thoroughly and pack into tight bins, boxes or casks, where water thoroughly so as to wet the entire mass. Repeat this every three or four days and in three weeks the bones will be found all melted down. 
Measuring Land.

Blue Grass.

Pulverizing Soil.

Subsoil Plowing.

Wire Grass.
969. Q. Give me some quickly approximative rules for measuring sur. face area of farm crops?

A. Assuming that the area of an acre is equivalent to a space seventy yards long by seventy yards wide, or 4900 square yards, we will call it for easy calculation 5000 yards. Now to measure any piece of land pace off in yards the length and multiply that length by its width, and its area is the whole, or more, or the fractional part of 5000 . For instance, if the length is sixty yards and the width thirty-four yards, it gives an area of 2040 square yards, or two.fifths of an acre, or if the length is 180 yards and the width 83 yards, the one multiplied by the other gives 15,100 yards or three times 5000 , consequently the area of the piece is three acres. To lay off a desired portion of an acre or more pace off in yards to see what is the length of the field, and multiply it by such number of yards in width as will make the proper fraction of 5000 , if the space is to be under an acre, or over 5000 yards if the space is to be over an acre. Purchase the little book titled The Farmers Land Measurer, by James Pedar. Price sixty cents. It is invaluable.

970. Q. Is not Kentucky Blue grass the best pasture grass?

A. It is so most decidedly. It is especially vigorous and particularly durable on soils of a limestone basis, in proof of which witness the perennial pastures, pastures good for a hundred years in the blue grass regions of Kentucky and Tennessee.

971. Q. Is it not bad practice to endeavor to pulverize the soil too finely?

A. No; the soil cannot be worked too intensely in any farm prepara. tion for cropping. Thorough cultivation is equal to an application of manure. Try it in any field for any crop; plow a section of a plowed field once more and note the result. Jethro Tull, of Berks, England, made himself quite famous in 1810 to 1820 by advocating thorough tillage, and subsequently thorough cultivation and hoeing, entirely in place of manuring, and while he did not prove his theory he demonstrated the wonderful results that could be accomplished by an intense system of working the soil.

972. Q. Is the practice of subsoil plowing beneficial to all soils ?

A. Only on soils having a hard understrata. If the subsoil is sandy down to a depth of twelve or fourteen inches-that is as deep as a subsoil plow can go-subsoiling will not be of any general benefit. The only aclvantage of subsoiling is to break up hard pan that surface water may pass down, or subterranean water rise, and that roots may ramify.

973. Q. How can I eradicate wire grass?

A. First dig it out with forks and then work the land every week. It is, indeed, best, to omit a year's cropping so that the field can be worked weekly. Do not give the roots a chance to get any breath through the agency of surface leaves. Destroy the leaves and keep them from developing, and the roots will die. 
974. Q. In what part of the cucumber, the skin or flesh, is the poisonous Cucumber. principle?

A. There is no poisonous principle. The cucumber is simply indigestible to some people. Delicate people eat cucumbers with impunity while others very robust cannot use them, their gastric juices do not contain the proper elements to digest the fruit.

975. Q. Tell me how a market gardener should lay up cabbage in the Cabbage Autumn to be drawn upon for market sales ?

A. Plow two furrow slices together, making a high ridge, and with a shovel dig out the furrow, throwing the earth on top of the ridge, which tramp hard. Iuto the open furrow stand the cabbages up perpendicularly, side by side, roots down, and tramp the earth hard against the roots, then with a plow throw a furrow slice against them, covering up to just underneath the head. Shovel out this new furrow as the first, filling it with closely packed cabbage as in the first instance. After thus filling several furrows on one side of the ridge repeat the entire operation on the other side. Cover with eight to ten inches of straw, on which place poles or rails to prevent it from blowing off.

976. Q. Is not rolling the land in many cases injurious?

A. Yes; and farmers are finding it out. Who now sees one roller where there were twenty that many years ago. A farm roller is a usefu] implement in dry weather, but should never be used when the soil is in condition to pack tightly.

977. Q. Is coal ashes good fertilizing material?

A. Coal ashes are of no value in themselves, but are sometimes useful in clay soils, as by their addition such soils are loosened or aerated. Coal ashes generally contain a small quantity of wood ashes which give them a little value as a manure.

978. Q. What is the relative value of sorghum as compared with field Sorglum. corn for soiling purposes?

A. Sorghum, ton for ton, is the superior because its stalks and leaves contain double the quantity of sugar found in Indian corn.

979. Q. In growing a crop of potatoes is fiat culture or hill culture the Potatoes. better?

A. Cultivation of the potato in hills was a system imported from Ireland and England, followed there by reason of the constant rains and wet condition of the soil ; but here, under our warmer sun and drier atmos. phere, flat culture is the best.

980. Q. Can I in any way prepare an Imitation of barnyard manure Barnyard which will resemble it in action, and cost but little?

A. You can make an apology for it by taking, say, two tons of swamp muck, seventy.five pounds of nitrate of soda, one hundred and fifty pounds of wood ashes, lwenty-five pounds of common salt dissolved in water, twenty-five pounds of fine bone meal, ten pounds of land plaster, twenty pounds of Epsom salts, dissolved in water, and thoroughly mix the whole mass, and let it lay for a week, when turn it over and let it 
lay for a month. This should not cost over five or six dollars, and will be found quite efficient as a fertilizer, but not so quick in action or so stimulating as barnyard manure, because its valuable parts are not so comminuted, nor is it in so good condition for assimilation by plants as that which has all of it before been within plant systems.

Starch as Food.

Celery

Preservation

981. Q. In what does the value of the starch in corn, or in any food, consist as a cattle-feeding substance?

A. It serves the purpose of a fuel, animals eating it prepare it for oxidation, after which it is in great part returned to the air through their respiratory organs. The oxidation and assimilation of starch imparts warmth to the animal and assists the digestion of all other classes of foods.

982. Q. How can I lay up my market celery for Winter so it will keep, and so I can get at it as I want to sell?

A. With a plow throw up a two-furrowed ridge and tramp it hard. With a shovel clean out the furrows, placing the loose earth on top of the ridge, which pack down with the back of the shovel, then on one side of the ridge stretch a line lengthwise and with a spade cut the earth down perpendicularly, opening a clean trench five to six inches below the general level of the ground, shoveling the loose earth on to the top of the ridge. Make this trench of such a depth that when the celery plants are stood up in it their tops will be even with the top of the ridge. In the trench stand up the celery three or four stalks thick, pack them tightly and fasten them in place with loose soil packed against the root by hand. When the trench is thus filled, run a plow alongside throwing the furrow slice against the celery, and open the new furrow close alongside with a spade, the same as the first, and repeat the operation of packing in more celery. On the other side of the original ridge perform the same operation. When this is done throw several furrows on the outside of both sides of the celery bed. Cover the celery with five or six inches of hay and that with four or five inches of long stable manure.

Weeds.

983. Q. Are weeds multiplying on the farms of the United States?

A. Yes; to such an alarming extent as to clearly demonstrate a want of energy on the part of the American farmer, particularly as the most troublesome weeds are foreigners, as, for example, the wild oat, ox-eye daisy, thistle, burdock and wild mustard. Weeds are objectionable because they extract fertilizing parts from the soil, drawing upon that food which should be used by the cultivated crops. Weeds increase the labor of working crops. They crowd a valuable crop so that it diminishes product, and they add to the labor of cleaning the grain crops for market. Few weeds are of any use for either man or beast, generally being bitter or acrid in taste.

Plant Nutrition

984. Q. Where is conducted the best system of investigation into the subject of plant nutrition?

A. At the Dramstadt Experimental Station, where the tests are all made in zinc tubs and pots, thousands of them, the largest about thirty 
inches in diameter and forty inches deep, the smallest pots about ten inches in diameter. The station grounds occupy about three and a half acres, and are so arranged that the pots are moved by tram cars in the open air on days not raining, but kept under cover during inclement weather. While the conditions of pot culture are not the same as in the open ficld, it is nevertheless the most exact system of research into the growth of plants, soil exhaustion and soil drainage, as the pots can be brought under the control and protection of the experimenter, while in the open field all sorts of complications arise.

985. Q. What is the soil in relation to vegetation?

A. It is both a laboratory and a mine. Certainly our own rich, black prairie soils are mines containing the vegetable accumulations of generations, but unfortunately by bad systems of cropping they are being exhausted. Of course the soil is also a laboratory, for all applied manures must pass through chemical changes and combinations effected to fit them for food for plants. A very small portion of the commercial fertilizers are, as applied to the soil, in a condition to be at once taken into plant systems simply by being dissolved in water, they have to undergo more or less change. If this were not so their action would be as quick and transient as a flash of gunpowder, whereas they often take two or three years to cease their activity.

986. Q. I never can grow a crop of perfect ears of sugar corn, the soft Corn Grub. grain always being badly cut by a grub in the husk. Can I prevent it?

A. The moth lays its eggs on the ear when it is very small, and the caterpillars are ready to enter the ear before it is half grown. Without a trial in the case the writer would venture to suggest the enveloping of the immature ear by bands of loose paper, or envelop them in loose paper bags like grape growers envelop grape bunches, but it would be necessary to permit the silk at the end of the ear to protrude, otherwise pollination would not take place. This very cxposure of the end of the ear might defeat the effort to preserve it from the attacks of the grub, for it might afford a fit resting place for a late flight of moths to deposit their eggs.

987. Q. Arc there insects beneficial to agriculture ?

A. There are thousands assisting in the pollination of flowers, Beneficia thousands of others destroying noxious species of insects. It is estimated there are in the world twenty millions of species of insects, and it is calculated that a million or more are advantageous to agriculture. About ten thousand species of predaceous or parasitic insects are known in the United States, but it will not do for the agriculturist to lay by and hope for nature to send to his aid a flight of insectivorous insects to eat up others, for the beneficial hosts are small in numbers as compared with the injurious forms. The well-known snake feeder or dragon fly, so common in Summer, is a showy representative of beneficial insects, as it lives upon others, which it kills.

988. Q. What are the names of twenty or thirty of the most common weeds. 
weeds found among the crops of the ordinary farmer of the South Atlan. tic States?

A. The writer cannot undertake to name all or even the most prominent, for those particularly noticeable in one section are less so in another, but the following list alphabetically arranged will certainly include many of the most troublesome :

Ainaranthus or Pigwig.

Bone-set or Indian Sage.

Bramble or Blackberry.

Burdock.

Buttercup or Crowfoot.

Chickweed or Mouse Ear.

Cheat or Chess.

Cockle Burr or Clot Burr.

Corn Cockle or Agrostemina.

Catnip or Catmint.

Daisy or White Weed.

Dock or Rumex.

Dodder or Flax Vine.

Dandelion or Taraxacum.

Garlic.

Indian Mallow or Abutilon.
Lamb's Quarter or Goosefoot. Milk Weed or Silk Weed.

Mullein or Velvet Plant.

Night Shade or Bitter Sweet.

Plantain or Buck Horn.

Purslane or Pussley.

Rag Weed or Bitter Weed.

Sorrel or Oseille.

Smart Weed or Knot Weed.

Shepherd's Purse.

Stramonium or Jimson Weed.

Thistle.

Wild Carrot.

Wild Mustard or Charlock.

Wild Radish.

Turnips. 989. Why is it that you recommend the growing of turnips as a restorative crop?

A. Because they can only be successfully grown after a good manuring, and after proper preparation of the land, the two operations being very obviously in the direction of high farming, the manure applied, generally barnyard manure, is only partially used by the turnip, a large proportion being available to following crops. The turnip tops all go back on the land either directly or as manure, and the roots, if used in the stable in fattening stock, are to a large extent voided by the animals, this excrement containing quite 70 per cent. of the nitrogen of the crop. Milch cows retain a larger proportion of the nitrogen than beef cattle. The turnip leaves which are returned, contain a large proportion of nitrogen also, and are worth double their cost. Thus the thorough preparation of the land, the manuring for the crop, the large yield of leaves from the crop, cattle excrement returned, all go to bring up the land to a high level of fertility and general condition. Consequently on farms where turnips are largely grown for cattle food, the general character of the soil is annually improved.

Nitrogenous 990 . Q. What is the effect of large applications to cattle root crops of Manures. nitrogenous manures, as rich barnyard manure, nitrate of soda and cotton seed cake?

$\Lambda$. They add very largely to the gross return, the tons harvested, but the percentage of sugar, the fattening ingredient in the roots, is not so high as in a smaller crop grown from less nitrogen. In other words, 
nitrogen produces large crops of roots aggregating a large amount of sugar, but seemingly not in proportion to the nitrogen supplied. An excess of nitrogen gives great leaf luxuriance, and keeps the plants unripe late into the season. As an adjunct to nitrogen as a food to root crops, potash is very important, the increase of sugar being much influenced by the amount of potash.

991. Q. Can I get goorl crops of truck by using 600 to 700 pounds of Supersuperphosphate to the acre?

A. Generally you can look for good resuits, but you don't get enough potash in ordinary superphosphate. As a rule, years of use and almost entire reliance upon superphosphate have brought about on garden soils a potash impoverislıment which seriously affects results. Potash is required largely by corn, clover, potatoes, and is eagerly assinilated by all garden vegetables, in fact it is never out of place. Don't adhere entirely to superphosplates. Its makers don't profess to furnish much potash. You cau get potash in wood ashes, and it is safe to apply one ton or fifty bushels to the acre, or you can get it in muriate of potash, using 200 or 250 pounds to the acre. Nitrate of soda can be applied, using 300 or 400 pounds to the acre. The urine of animals is especially rich in potash and should all be saved by absorbents placed in the barnyard, and the manure pile should be kept under a shed and not be exposed to the leeching effects of rain.

992. Q. Is the sweet potato of the same family as the yam.

A. No, they are of distinct genera, the sweet potato being, it is thought, Potato. a native of Central America. In 1526 it was in general cultivation in St. Domingo and other West India islands. Botanically it belongs to the Convolvulus family oi dicotyledonous plants. The edible portions are true roots. In China there is an edible root some what resembling it but of the Ipomæa family. The various species of yams cultivated in the United States belong to the widely scattered Dioscorea family and are believed to have been brought from Africa. Theyare monocotyledonous plants, markedly distinct in this particular from the dicotyledonous sweet potato, and the yams are distinct also in their flowers, as in them the sexes occur on different plants, while in the sweet potato the sexes are found on the same flower. The edible portion of the yams are underground stems, while in the sweet potatoes they are roots. The distinguishing qualities between the sweet potato and the yam is too well known to need description.

993. Q. Do most garden vegetable plants fertilize or pollenize them-Pollination. selves.

A. A great many do: but quite as many absolutely require the aid of insects to carry the pollen from one fluwer to another, or to loosen parts of the flowers of monœcious plants that fertility may take place. A familiar example is found in the bean, pea, and clover plants, where the visitation of an insect at the right time causes the stamens to discharge a cloud of pollen. It is said that bees when visiting the flowers of beans 
instinctively alight or creep upon the flower, so that their weight causes the pistil to protrude to reeeive the pollen. A hundred other instances of equally curious character could be quoted. Prof. Beale, of Michigan, has conducted experiments in the covering of flowers with gauze to prevent the visitation of the flowers by iusects, and reports in many instances no seed set.

Sexes in Flowers.

Vegetable Growth.

Sowing Grass.

Okra.

Air in the Seil.

Seed Control.
994. Q. What are terms used to indicate the sexes of regetable plants?

A. When the flowers have stamens alone, the vegetable plant is termed a male or staminate plant. When with pistil alone, it is termed female or pistillate. When both male and female organs are found on the same plant, it is termed a moncecious plant. When the male and female organs are found on different plants, it is diccious. When unsexual or hermaphrodite flowers are on the same plant, it is termed polygamous. When male and female flowers are both absent, it is termed neutral.

995. Q. In what form does the growth of vegetables occur?

A. By the laying on of cells or an increase of the whole plant. "Vessels producing vessels and cells producing cells." In animals every part of the frame and flesh is renewed from time to time, it being commonly understood there is a complete change every nine or ten years, but in vegetables, except in leaf and bark, there is no renewal of parts once formed, the entire growth is in the line of new matter to be piled on top or on the exterior of that already formed.

996. Q. Is it a good plan to sow grain with young grass for purposes of protecting it?

A. It is a bad plan, as the more vigorous grain smothers the tender grass in the Spring, making it still more tender. Better get your grass in early in the Autumn so as to give it a good start, and let it take its chances, for if well started it won't need grain as a nurse.

997. Q. Why is the okra almost unknown in Northern markets?

A. It is preëminently a Southern vegetable, but it can be grown wherever sugar corn will flourish. It is little cultivated, however, north of Baltimore ?

998. Q. Do roots of garden vegetables require much air?

A. Yes; just as much as leaves, as is proven by their death when deprived of air or when grown in poisonous gas, as carbonic acid. This shows one of the advantages of deep and frequent culture. Neither leaves nor roots have organs corresponding to the lungs of animals nor to the gills of fish, but they in some way absorb air and make use of it as an absolute necessity. Air at the roots of plants is necessary to present the water of the soil in best condition for absorption by the roots, as they do not absorb water so much as watery vapor, hence air is necessary among other things to absorb the water and present it in vapory form.

999. Q. Is there any Government control of the seed business for purposes of preventing fraud?

A. No! But there might be to advantage. Every department of art or science has its humbug, and it would be strange indeed if 
that one which is the oldest and most extensively practiced was free. Agriculture and horticulture must be content to bear their shares, for like in the treatment of weeds, cast out as many as we will, some germs remain, and like weeds with the warm of returning Spring, the humbugs are reanimated and spring up with smiling faces. Many of the State Experimental Stations have for some years been engaged in analyzing commercial fertilizers and publishing the results, all of which las been very beneficial as indicating to the farmer fraudulent brands, consequently fewer of such are now made than formerly. It is quite within the scope of the work of experimental stations to take up the question of seeds and to publish sworn reports of vitaity tests of seeds obtained from various seedsmen, and the results of microseopic examinations in search of weeds, imperfect and moldy seeds; and subsequently reports of quality as shown in the experimental garden. Such Seed Control Stations, as they are termed in Europe, will certainly be established in this country as well as abroad, as the work there is much appreciated, particularly in Germany and Austria. No farmers, no market gardeners, or private gardeners, as the Americans, sow so large a proportion of poor seeds, because there are so many of such imported. Many European seedsnien seem to think anything is good enough for the American market, some of them sending here what they would not sell under their own names in their own countries. The ordinary farmer or gardener purchases the lowest price seed he can get, and consequently he gets lots of weed seeds in his grass and clover, and the vegetable market gardener often gets stocks much doctored. A low price for seed nowadays condemns it in the estimation of those who know, for if it is good it cannot be priced below the normal value.

1000. Q. What is the object of bleaching celery?

A. Celery is bleached to get rid of the acrid quality which is always Bleachingo present in the green chlorophyll situated in the leaves between the upper and lower epidermis. The chlorophyll when green contains iron, an essential to all green plants, and is acrid and bitter, but bleached it loses the iron and its objectionable flavor with it, and becomes mild and sweet.

1001. Q. How late in Summer can I plant garden seeds so that I may bave a farr expectation of a crop reaching edible condition before frost? Seeding

A. 1. Average, and note down, the date of the first killing frost in your Periods. neighborhood.

2. Calculate, and note down, the number of days required from date of germination to obtain edible condition required by Spring-sown garden crops in your district.

3. As Summer and Autumn crops generally grow slower than Spring crops, add ten or fifteen days to the usual number of days required for Spring-sown crops and you have the number of days preceding the day of frost required by an Autumn crop to develop into edible condition.

4. In Pennsylvania the periods usually required for quickly developing 
garden vegetables to reach edible condition are about as follows : peas, forty to fifty days ; beans, forty to fifty days ; corn, seveuty to seventy-five days ; cucumber, seventy to eighty days; radish, eighteen to twenty-five days; spinach, forty to fifty days; tomato, one hundred to one hundred and twenty days. For Autumn cropping add ten to fifteen days to each period.

Breathing Pores.

Mangel Wurzel.

Club

Root.

Sugar Corn.

Rotation.
1002. Q. How many breathing pores are there to the inch on the leaves of most garden vegetables?

A. Tle pores are called stomata, and give passage to air, serving the purpose of expiration and inspiration. On most plants there are one hundred to five hundred thousand to the square inch.

1003. Q. In what way do Mangel Wurzel differ from Swede turnips?

A. Mangels, which are large growing beets, have to be sown a month earlier than Swedes, which are of the turnip family, the Mangels requiring a longer period to develop. The Mangel roots deeply, and is not so dependent upon frequent rains, as it has powers of accommodation to fluctuating circumstances greater than the turnip. It is more leafy, and is a plant requiring a higher temperature than the turnip. It is a gross feeder, requiring a heavy dressing of manure, and is particularly developed in growth by nitrogenous food.

1004. Q. Part of my truck patch was last year affected by club root, and as I am limited in capital I cannot afford to rent new land, now what can I do to remedy the evil?

A. In the Winter broadcast seventy-five bushels of air-slacked lime to the acre, also one thousand pounds of kainit, and before seeding in the Spring, apply to the acre four thousand gallons of water having in solution forty pounds of corrosive sublimate.

1005. Q. When was Sweet or sugar corn introduced ?

A. The Eight Rowed sugar corn was the first introduced, and while it appeared generally in seed catalogues about 1840, and was in 1830 offered for sale by one or two leading seedsmen, it was not till about 1850 that it became generally appreciated as superior to the field corns used generally for "roasting," as corn was cooked in those days, the varieties used for table purposes being then the Early Canada, Horse Tooth and Tuscarora. But sweet corn was known many years before, as there are records of its existence among the Indians on the Susquehanua river as early as 1779. Pure sweet corns are nearly all very oily, very little starch being visible, the oily condition being expressed by the word corneous or horny, and just as soon as this condition begins to breed out, such types cease to be true sugar corn.

1006. Q. What is the benefit of rotation of crops?

A. A change every year of crops on a field, especially so that the crops of same nature do not go back for five or six years, is highly advantageous, as the alternating plants if properly selected do not require the same quantities or conditions of plant food, and even if the artificial additions of man. ure are only moderate in quantity, there may be through the processes of 
soil decomposition an accumulation of some of the fertilizing constituents needed by the first series of plants when the time comes to repeat the series. Another benefit of the rotation of crops is that some of the crops are nearly all returned to the land, while if the cultivation was continuous of crops to be sold off the land, soil exhaustion would be certain to follow.

1007. Q. Are there many plants poisonous to the touch?

A. There are several plants poisonous to nearly every one, and many Plants. others poisonous to persons of peculiar susceptibilitics; for example : the poison ivy, sometimes called poison oak, a climbing vine, is harmless to the writer, but many people cannot touch it, some can hardly pass it on the leeward side, without being poisoned, on occasions when it has been cut or torn, as it then exudes a caustic milky juice, which, brought in contact with the skin, develops blisters. The poison sumac, a small tree grow. ing in swamps and in damp places, exudes a sap which touching the arms or hands of many people raises painful blisters. The cultivated parsnip is poisonous to many people. There are many plants poisonous when eaten, possibly forty to fifty distinct genera in the eastern United States, but most of them no sensible person would think of eating for none such are attractive. Animals sometime eat poisonous plants, and no doubt many mysterious affections of horses and cattle may be attributed to this cause.

1008. Q. Give me a table of the periods of time required by garden Maturity vegetables to reach edible condition after germination?

A. Any data in this line is merely approximative, as the period is lengthened or shortened by conditions of moisture or heat, age of seed, vigor of seedling, depending upon its physical condition and soil enrichment. The following periods of days of time are intended to comprehend the earliest and the intermediate, not the periods of maturity of the latest sorts:

Radish, 18 to 30 days.

Lettuce, 25 to 35 days.

Turnip, 40 to 50 days.

Spinach, 40 to 50 days.

Beets, 40 to 50 days.

Peas, 40 to 60 days.

Beans, 50 to 60 days.

Corn, 70 to 75 days.

Cucumbers, 70 to 80 days.

1009. Q. Tell me a simple remedy to destroy green worns infesting my Cabbage cabbage plants?

A. When the dew is on them, best done at night, sprinkle very finely pulverized salt over the plants. The dew will dissolve the salt, and the salted water wherever it touches a green worm will kill it, but don't salt the plants too much or they will be killed also.

1010. Q. Which kinds of field corn are the quickest and most certain to germinate?
Squash, 80 to 90 days.

Cantaloupes, 80 to 90 days.

Large onions, 80 to 100 days.

Carrots, 85 to 90 days.

Watermelons, 90 to 100 days.

Cabbage, 100 to 130 days.

Tomatoes, 100 to 130 days.

Punpkins, 100 to 120 days. Torms.

Vegetables. 
Tepper Plants.

Corn, Early Cultivation.

Vitality of Cabbage Seed.

Onion Sets Weights.
A. The Flint sorts are the quickest to sprout and the most reliable. The softer the variety the greater the possibility of decay. The pop corns may be taken as representative of the hardicr sorts.

1011. Q. I have a one-quarter acre patch of pepper plants, very tall and a mass of foliage, but not a fruit set. Can you explain this?

A. It is probably due to overmanuring, inducing too luxuriant a growth, the nourishment necessary to produce flowers and fruit being all taken up in the formation of wood and leaf. Try root pruning by running a plow on one sicle, so close as to cut quite one-third of the roots of every plant, this check may cause the number of blooms to increase and fruit to set. While flowering and fruit-bearing is an exhaustive process requiring a large amount of nourishment, it does not advance the process to manure too highly, as it is generally the half-starved plants which are most productive. It is very noticeable that vegetable garden plants of an usual number of flowers are always weakest in growth, and conversely, the very vigorous growers produce few flowers. It is just the same in the animal kingdom, the herdsman well knows that a lean cow is the most reliable breeder.

1012. Q. Did the early Amcrican Indiaus cultivate corn to any extent?

A. The author takes the liberty of answering this query by making some extracts from the pamphlet of Dr. E. L. Sturdevant, South Farmingham, Massacliusetts, "General Sullivan at the time of his expedition against the Indians in 1779, destroyed twenty thousand bushels of corn at Genesee, New York. De Nowville, in 1687, in the same region, destroyed twelve hundred thousand bushels. Fontienack, in 1697, employed his army for three days destroying corn. In the Pequot War, in 1636, the English destroyed 200 acres on Block Island, and in 1675 they harvested 1000 acres of corn in one place. General Wayne, in 1794, wrote of the Delawares in Ohio, 'I never before beheld such immense fields of corn.' In 1498 Columbus reported his brother as having passed through eighteen miles of corn fields on the Isthmus. In 1520, the ships of Magcllan were supplied with corn at Rio Janeiro."

1013. Q. What may be cousidered an average of vitality of cabbage seed?

A. In 1887 the New York State Experimental Station made tests of 164 packets of cabbage seed procured from fifteen different seed merchants, testing 32,800 seeds in samples of 100 each, and found the highest test to be 94 per cent. and the lowest 48 per cent., the general average being 76 per cent. To arrive at the valious vitalities of same seed under distinct tests the station authorities next took several distinct samples from each lot and tested them, and found an average variation of 15 per cent. to 20 per cent. between the lots of seed, due to some slight difference iu soil or atmospheric conditions. An illustration that little reliance can be placed on tests unless reported at different intervals and under different circumstances and the average result calculated.

1014. Q. What is the legal weight for a bushel of Ouion Sets? 
A. There is no fixed weight, and there could not be, for they are constantly decreasing in density by evaporation of moisture. Two bushels measured and stored away in September will not measure more than one bushel in March. On October 1, the Bloomsdale Farm sets weighed fortyfour pounds to the bushel, as measured, but they are not sold by weight, but by measure.

There are all sorts of ways of selling sets-some people give thirty-two pounds, others a stroke bushel, others a heaped bushel, and prices vary accordingly. As an example, \$2.25 for a bushel of thirty-two pounds is no cheaper than $\$ 3$ for a bushel of forty-two pounds. By reason of shrinkage they increase in value quite twenty to twenty-five cents per month per bushel.

1015. Q. What is the annual quantity of potatoes imported?

A. For the year ending June, 1894, the quantity was over three million

Potatoes bushels, valued at over one and a quarter millions of dollars, Scotland sending over one-half of the total quantity.

1016. Q. Will it pay me as a market gardener to devote one of my glass Market houses to the Winter culture of tomatoes?

A. It will if you are an expert in such work, or are quick to learn. The house should be separated from others, as they might be sometimes too high in temperature, and other times too low. The mercury in a tomato house may vary from seventy to ninety degrees during the day, should not fall below sixty-five to seventy-five degrees during the night. There should be head room of quite fire feet between the soil of the benches and the glass to admit of space for the extension of the vines. The plants should be set about fifteen inches apart and trimmed to single stalks, these trained to sticks or cords. Early sorts should ripen fruit in about 110 days from the germination of the seed. Natural pollination of tomatoes under the conditions of glass-house culture is not sufficient to give a full crop, hence the pollination must be assisted by artificial means. This can be done by jarring the pollen from the flowers into a spoon, and thrusting into the spoon the stigma of the flower to be fertilized. It is important that this be done thoroughly, as imperfect pollination results in imperfect fruit and a small crop. When the fruit becomes beavy the strain should be taken off the plant by artificial support given to the fruit. A plant should give about three pounds of fruit. For under-glass culture try the three Landreth Cross-Bred Varieties, the Red Cross, the Purple Cross and the Two-Celled Cross, all entirely distinct from any of the standard sorts. Very early, very prolific, very deep in shape, very solid and smooth.

1017. Q. Is the nutritive or feeding value of all turnips or all beets the Feeding same?

A. Very different; not only between the families of turnips and beets, of but between the sorts of each family, and still again between the crops of Turnips the same sort grown on fields of different quality, or different manuring, Beets. or grown after different periods of drilling, or under varying conditions of 
solar light, and consequent upon different degrees of maturity. Cattlefeeding roots are largely composed of water ranging from 80 to 90 per cent., consequently the nutritive value is measured by the amount of dry matter which varies in white turnips from 7 to 9 per cent.; yellow turnips 8 to 10 per cent.; Swedish turnips 10 to 12 per cent.; mangel wurzels 10 to 14 per cent. To be more exact, in the estimate of value must be considered the amount of sugar in this dry matter, and it may be approximately stated as in white turnips 40 to 50 per cent., yellow turnips 40 to 50 per cent., Swedish turnips 50 to 60 per cent., mangel wurzels 60 to 70 per cent. Sugar is technically known as a carbohydrate, and as a cattle food it forms fat.

1018. Q. I have a good crop of potatoes this year, having just put away, my crop from seventeen acres of 3380 bushels, or 260 bushels to the acre. Is that quantity often grown?

A. No, it is not; 200 bushels is a big crop of well-sorted, fairly measured potatoes. On that quantity most farmers would be glad to compromise as a regular return for a term of years, but occasionally it is exceeded not only twice, but three times; for instance, at the Chicago Exhibition there was shown by New York State farmers samples of crops certified to be grown from measured acres of the following varieties and quantities :

Maggie Murphy, 810 bushels.

Ideal, 675 bushels.

Earls Rochester, 656 bushels.

White Flower, 640 bushels.

Albany Seedling, 574 bushels.

Potato

Varieties.

Squash or Pumpkin.

1019. Q. Name me some good sorts of potatoes, early, medium and late.

A. For very early. - Early Ohio, Irish Cobbler, Bliss Triumph.

For medium early. - Early Vermont, Reeves Rose, Holton Rose.

For late.-Freenan, Green Mountain, State of Maine, Peerless, Gar. field, Rural New Yorker, American Giant, Rural Blush.

1020. Q. To what botanical family does the squash and pumpkin belong?

A. They are not of one family, but of two distinct cliaracters, the squashes being of the genus Cucurbita maxima while the pumpkins are of the genus Cucurbita pepo. Botanists classify them according to the formation of their leaves; for instance, those of entire or undivided leaves are of the maxima or squash family, comprising the Hubbard, Marblehead, Boston, Mammoth, Fordhook, Chili, Red Turban, Bologne, Etampes, Sweet Potato, Winter Crook Neck, and, strange to say, the Cheese and Cashaw, ordinarily ealled pumpkins ; while on the other hand, those of subdivided or cut leaves are of the pepo or pumplin family, represented by the Negro pumpkin, the Yellow Field, Nantucket, Golden Summer Crook Neck, White Bush, the last two ordinarily called squashes. The undivided or entire leaves of the maxima, while hairy on the surface and 
on the leaf stalks, differ from the cut or divided leaves of the pepo family, as the leaves of this last are much more harsh and bear upon the foot stalks quite stiff and spiny thorns. $\Lambda$ nother difference is that the maxima or squash family, as a rule, develop thick, swollen, woody fruit stalks, and their blossoms generally are lemon colored, while those of the cutleaf sorts produce small fruit stalks and the blossoms are generally orange in color. This classification, made according to form of leaves, character of spines and fruit stalks, mixes up familiar pumpkins and squashes to a puzzling extent, as under it Early White Bush squash becomes classed as a pumpkin and Cashaw pumpkin becomes classed as a squash. For practical purposes the farmer's test is the best, and that is, when he can stick his thumb nail into the rind after reaching full development it is a pumpkin, when he cannot it is a squash, as its rind becomes hard as wood. A close physiological relationship is indicated and determined by the crossing of sorts, which will occur freely if they belong to the same family, and seldom in cases where they are of distinct families.

1021. Q. Down here in Louisiana, large quantities of crude molasses Molasses a are allowed to go to waste, and I write to inquire the value of molasses as Cattle a food for cattle and pigs?

Food.

A. Forty years ago Dr. Lawes, of Rothamstead, conducted experiments to determine the value of sugar as a food for pigs, and arrived at the conclusion that sugar had the same high value as pure starch. Since then Letimen, of Göttingen, has tried feeding sugar to sheep, and found it of the same value as the non-nitrogenous ingredients of other cattle foods. His experiments were satisfactory but developed nothing remarkable with respect to the nutrition of sheep. Subsequently he tried sugar on several lots of pigs, and found in all cases that its addition to the regular ration increased the amount of total food consumed and increased correspondingly the weight of pork. The estimate of increase being threetenths of a pound of live weight for each pound of sugar consumed, or stated in another way, one pound of gain in meat was produced by three and one-third pounds of sugar. By the results of these experiments it would seem well worth while to utilize a portion, if not the whole, of the molasses wasted. It might be used with some absorbent and kept in silos. It should not, however, be used without caution, as it contains various salts which might make it strongly purgative. In no case could it be depended on as a complete and only food.

1022. Q. Is there more than one kind of mint?

Mint.

A. There are three plants to which this name is applied :

1. Spearmint, a native of Europe, botanically known as Mentha viridis. This is used for seasoning. It flourishes in a cool, moist soil and a bed of it will last for several years.

2. Peppermint. This is cultivated largely for its oil, the census reports showing about 6000 acres are cultivated in the United States.

3. Catmint or catnip is a plant distinct from the two preceding. It also furnishes an essential oil, aromatic, stimulative and anti-spasmodic. It 
flourishes in the Southern States, and by some is used in Summer drinks as a substitute for spearmint, which is the proper article for such purposes. Germination 1023. Q. Why is it that July and August sowings of lettuce seed so of Lettuce. frequently fail to germinate. I live in Florida, and Midsummer sowings of lettuce are the most profitable. I attributed the fallure to getting old seed, but I have bad the same seed to give good results sown at a later period?

A. This is clearly attributable to unfavorable conditions. You may have put it into soil too dry to afford the necessary moisture to swell the seed, or if swollen, the germ may have been parched by earth burning hot, or you may have covered the seed too deeply, some lettuce seed should never' be covered, but just tramped or patted down. The following is an exact copy of a letter received from a seed merchant to whom the firm of the writer sold some lettuce seed.

"I regret exceedingly that I was misled by Truckers in regard to the germination of your Royal Cabbage lettuce seeds, and I now find that they were impatient, unreasonable and their reports entirely untrue, as I sowed your seeds in a box, on the $2 \mathrm{~d}$ of this month, and I find them un well this morning, and besides, one of the men who had this seed told me, not ten minutes ago, that his was up too thick and that others in his section told him yesterday that it was now coming up nicely, and I now write to apologize to your firm, as I feel very sorry for what I said two or three days ago, believing as I then did, from the reports of so many, that the seeds were worthless."

1024. Q. Furnish me with a list of two or three sorts of each leading table vegetable suitable for a family garden in the vicinity of Baltimore.

Peas.-Extra Early, American Wonder, Bloomsdale, Phonograph.

Beans.-Red Valentine, Landreths' Scarlet, Pink Eye Wax, Pole Lima.

Corn.-Crosby, Landreths' Sugar, Evergreen.

Cabbage._Early Jersey Wakefield, Reedland Early Drumhead, Bloomsdale Large Late Flat Dutch.

Carrot.-Pointed Horn, Ox Heart.

Celery._-Paris Golden, White Plume.

Cucumber.-First, Landreths' Choice, White Spine.

Egg Plant.-Thornless.

Kale.-Bloomsdale Extra Curled.

Lettuce.-Forcing, Virginia Solid Header, Bloomsdale Reliable.

Watermelon.-Boss, Arkansas Traveler, Long Light Icing.

Cantaloupe.-Jennie Lind, Anne Arundel, Missouri.

Onion.-Bloomsdale Pearl, Bermuda Red, Hard Round Golden.

Okra.-Long Green Pod.

Parsnip.-Bloomsdale.

Radish.-Landreths' Earliest, White Lady Finger, Wonderful Half Long Red.

Spinach.-Bloomsdale, Ever Ready. 
Squash.-Extra Early Bush, Golden Summer.

Tomato.-Extra Early Richmond, Acme, T.T.T.

Turnip.-Early Dutch, Amber Globe, Bloomsdale Swede.

1025. Q. Are the original wild types of our cultivated plants generally Original to be found?

A. Very few of them. The wild cabbage, celery and beet are met with in Europe, the potato and tomato in South America, and a few others elsewhere representative of our garden plants, but very few. Still less of the cultivated products of the field, as there is no wild rye, wheat, oats or barley, nor Indian corn in its original condition. Of the origin of plants in general hardly anything is known, aud very little to be surmised. This much is known, however, strange to relate, that the United States has furnished comparatively nothing of value among cultivated plants of vegetables or cereals, the principal nutritious plants being the Jerusalem artichoke and the gourds, both of little value, and among the cereals the Wild Rice. The United States is not an exception in this particular, for not a useful original plant has ever been obtained in Australia, or New Zealand, or the Cape of Good Hope, nor from South America, south of the Platte. These countries produce plants useful to savage man, but they have never been improved by selection, as have the plants of Europe, Asia, Mexico, Central Amcrica, Chili and Peru, plants probably no better originally, but a clear demonstration that it was only among the higher civilized people of early times that improvement by selection took place.

1026. Q. As in a late letter you urged me to adopt market gardening Lettuce. under glass, let me ask you to what special crop would you advise me to give special attention?

A. To lettuce. It is in demand for fifty-two weeks in the year, and always, when in fresh condition, will bring a good price. In Philadelphia, during the months of December, January, February and March, good lettuce is sold by the commission men to the city storekeepers at from $\$ 5$ to $\$ 10$ per hundred heads. It is generally highest in January and February, and assuming that its average price then is $\$ 7$ per 100 and the freights and commission $\$ 2$, it leaves $\$ 5$ to the producer. When lettuce is well grown sixty to seventy-five heads will fill a barrel. In growing lettuce it is important to get seed true to name and of strong vitality, and of habits of uniform development, that sections of the forcing house may be entirely cleared of crop, that the space may be promptly recropped with a fresh setting of lettuce or radish. Two good sorts for forcing are the Virginia Solid Header and Forcing, the latter the New York experimental Station has pronounced of high merit for under-glass culture.

1027. Q. Is ensilage a good food for horses ?

A. No; it is likely to produce colic, and weaken them generally. The digestive organs of horses are different from those of cattle, which are cudchewing animals. Indeed, ensilage for cattle is not always the best food, as it sometimes has the same effect as brew-house swill, causing cows, especially when fed too long upon it, and too exclusively, to become unhealthy, to grow languid and to lose their hair. 
Vegetable Foreing Houses.

Potato.

Depression in

Market Gardening.
1028. Q. What are the general dimensions of the vegetable forcing houses operated by market gardeners growing truck for Winter sales?

A. The writer knows of houses $240 \times 30$ feet ; $250 \times 40$ feet ; $400 \times 40$ feet; $1600 \times 20$ feet. And possibly there are yet more extended areas of glass entirely devoted to growing vegetables for Winter sale, as lettuce, radish, cucumber, tomato, watercress.

1029. Q. Is not the potato one of the most healthful foods?

A. No; it might more properly be classed, as ordinarily served on the table, as an unhealthful food. The reason is that the potato is composed to a large extent of starch, which to become nutritious has to undergo a sugary change by the action of the stomach juices, and this change is particularly slow in the case of the potato, as it is a dense food slowly acted upon by the digestive fluids, and consequently it remains for a longer period in the stomach than rice or any other starchy food. This retention in the stomach results in the partial decomposition of the starch, the evolving of gases and formation of combinations which distend and irritate the stomach and intestines, producing in some persons dyspepsia and diarrhœa. Strong constitutions apparently resist the slightest injurious influences from this cause, but nevertheless their digestive organs are at the same time taxed to a greater extent than if the food was rice, which, by the way, is not a quickly digested food. Potatoes as a food are most objectionable when fried, most wholesome when baked.

1030. Q. What is the cause of the depression in market gardening?

A. Overproduction, and consequently overcompetition and lowering of profits, the same cause as produces agricultural depression. Any thoughtful market gardener clearly realizes the cause to be the opening of the many and new truck-groving sections, almost limitless, in the South Atlantic and Gulf States, in the Middle Cotton States, and throughout the entire Mississippi valley, all these throwing at all seasons into all the markets of the country, especially the Northern cities, such an avalanche of fruit and vegetables as to have almost completely obliterated the profits of the Northern market gardener, and as well most seriously cut down the receipts of the Southern truck farmer, the prevailing agriculturial depression having turned to market gardening tens of thousands of regular farmers.

It might in this connection be asked, What has caused the agricultural depression? and the reply is, The same overproduction; the result of several causes. One, the opening up in our far-Western country of millions of acres of new lands to foreigners to grow competing crops of wheat, corn and potatoes, which they do at comparatively little expense. Another cause, the development of field machinery, by which ten men do the work of one hundred in the past, consequently every proprietor is able to seed and harvest ten times the number of acres. Another, the development of railroad transportation, by which the product of most distant parts is brought to the seaboard to compete with that grown upon 
land in the old States held at $\$ 100$ per acre as compared with $\$ 5$ land in the far West.

But an influence greater than the three enumerated is the scaling down of American values of wheat, and by sympathy corn also, to the grain prices of London, in which market are fixed the grain values of the world, dependent on the crops of Russia, India, Egypt, New Zealand, Australia and South America. It is these crops which fix the value of our crops in America, for if the price in London is low, and it generally is low, the grain can be sent from Europe to the United States at a cost of six cents a busliel, and yet cheaper if sent from point of production.

1031. Q. What will be the result of the agricultural depression?

Agricultural

A. In our late letter to you we very briefly treated upon the cause of Depression. the agricultural depression. The result is a problem which only time can solve. But certain results are very apparent, notably the frequent sheriff sales and the abandonment of thousands of farms in all of the old Eastern States, lands once high-priced, and yet, though depreciated, too expensive to cultivate. Nuch has been written about the abandoned farms of New England, but the same condition exists in the Middle Eastern States.

In New Jersey and part of Pennsylvania ean be seen thousands of abandoned farms with broken-down barns and fences, tenantless homesteads with weedy front-yards. The selling value of these farm lands is only one-third what it was under the better times of twenty to thirty years ago. And though rents may now be based upon the reduced value, they cannot be paid out of the farm profits of ordinary agriculture, if the farmer is of the condition of a proprietor and has to pay wages.

It seems manifest destiny that the day for big farms in the old States is about over, and that grain, grass and dairy lands will be divided into tracts of thirty to forty acres, and worked by small owners or renters, a less intelligent, less progressive class, men who cannot afford to, or who will not purchase improved machinery, or be in any way helpful in aiding advanced agriculture. Each holder of this class, by the aid of his wife, sons and daughters, doing all the work, no cash going out to employés, people satisfied to eat what they cannot sell; such people will lay by money, but they do nothing to aid in the development of the science or practice of agriculture. This is not a very cheerful prognostication, but it may come true.

These remarks apply to ordinary farming, not market gardening, under which more intensive system of culture forty acres is frequently enough, as forty acres in truck requires the labor of five or six men and as much outlay in manure, live stock and implements, ability and effort as five times that average in crops of grain, potatoes and grass.

1032. Q. What is a practical proof of the activity of bacteria in the soil?

A. It has been proven by the Rothamstead Experimental Station that nodules growing on the roots of leguminous plants, as peas or clover, 
Rich

assimilate nitrogen both from the soil and by fixation, and the evidence of fixation of nitrogen has been proven by Dr. Gilbert in his experiments with leguminous plants grown on land made free from nitrogen, but subsequently inoculated with bacteria soil, the nitrogen obtained being only from the air and through the active agency of the bacteria.

Agricultural one in agricultural produce?

Counties.

A. Lancaster, $\mathrm{Pa}$. It is thirty-three miles long by twenty-eight wide, and comprises 928 square miles. Part of it has been cultivated since 1709 , and yet it has not a single acre of worn-out land. It contains 9070 farms, valued at sixty-nine million dollars, and produced last year farm produce of the value of nine million dollars, or fifty per cent. greater than any other county in the United States. A leading production for years has been tobacco, of which in 1889 the value was one and one-third million doilars. Lancaster county contains $325 \mathrm{grist}$ mills, and last year wintered forty thousand stall-fed cattle. The other counties in the United States producing the highest value of agricultural products is St. Lawrence, N. Y., producing six millions of dollars, but its area is three times as large as Lancaster. The third productive county is Chester, Pa., one quarter smaller than Lancaster, producing nearly six millions of dollars. The fourth county in production is Bucks, Pa., onethird smaller than Lancaster, producing five and one-half millions of dollars last year. It is in Bucks county where is situated Bloomsdale Farm.

Corn Crops. 1034. Q. Maryland is not far behind, for I have just measured up my coln crop of 1479 shelled bushels grown on seventeen acres. Is that quantity of eighty-seven bushels to the acre often exceeded?

A. Not often excceded in general cropping, for eighty-seven bushels is a most admirable product, but it is not as much as often grown in the crack counties of Pennsylvania, Delaware, Lancaster, Chester and Bucks, where there are many records of over 100 bushels, and as high as 127 , which was certified to by the Brandyne Club in 1874. In 1893, a Pennsylvania farmer exhibited at the Chicago Exhibition a lot of corn, part of the product from a twelve-acre field which gave 1320 bushels, or 110 bushels to the acre.

Ensilage. $\quad 1035$. Q. What is meant by ensilage?

A. The principle involved is the preservation of green forage in cellars or pits through the exclusion of air, the green stuff being put in so tightly as to drive out very nearly all the air, and the material kept so compressed as to continue to keep out very nearly all air. Some will remain, but this, after a time, is changed by fermentation to carbonic acid gas, filling all interstices, excluding other air and holding the green forage in a bath of gas, in which condition all decomposition is arrested. The forage clianges its color in the pits, and a vinegary odor becomes very perceptible, the material becoming more digestible than it was in its green condition. 
It is the cheapest, most economical and satisfactory way of feeding milking cows, not used exclusively, but in connection with a proportion of cake meal, and with a proportion of dry hay or fodder. Cows thus fed thrive well and milk freely, giving sweet milk, making good butter. For this reason it is every day growing in favor, especially as it is so palatable and easily digestible. The ensilage of the present day is made from well-grown, well-matured, well-eared corn-of course taken in green condition, chopped in to pieces of about one and one-half inches in length. White Sheep Tooth corn is the best for the purpose, being very abundant in the production of foliage.

1036. Q. What is the object or work of the Agricultural Stations?

A. By their investigations they protect the farmer against sales of fraudulent fertilizers and cattle foods. They study cattle diseases and advise preventive measures; they investigate the habits of insects injurious to agriculture and designate methods of destroying them ; they study the character of fungous growths; they inquire in to methods of irrigation and into meteorological and climatic fluctuations and results; they report on qualities of soils, qualities of new cereals, forage plants, vegetables, fibres and fruits, action of fertilizers, plant nutrition and component parts of soil drainage. They do entirely too much to enumerate in a short description of their work, which is an extensive line of research in the laboratory and hothouse, in the stable and dairy, in the orchard, forest and field. They do so much original work and collect so much of the results of work of other stations as to be important bureaus of agricultural information. Every State has one agricultural station; Connecticut, New York, Alabama and Louisiana, each two. In the aggregate they employ nearly 600 persons, and in 1894 issued over four and one-half million reports and bulletins. The first American agricultural station was established in 1875 in Connecticut, but this was thirty years after the establishment of the first German agricultural station, which was at Mœc. kern. One of the most interesting of the many advanced agricultural stations in Europe is that of Darmstadt, largely devoted to pot investigations, into plant nutrition and soil exhaustion.

103\%. Q. In what way did mankind find out what plants were edible? Edible

A. Such explorers as Livin gstone, Hooker, DeCandolle and others, all Plants. found that uncivilized man in all countries knows a long catalogue of plants, more or less nutritious, others injurious, others destructive to life. In $A$ frica the natives in the wilder regions are guided to a great extent by what the baboons and monkeys cat. All wild tribes through pressure of necessity have learned a great deal as to the effects, stimulating, nutritious and medicinal, of many of their native plants, and a consequential step is the removal of these plants, or the planting of their seeds by the natives near to their huts, and thus the first steps are taken in the line of selection, to be further continued by subsequent selections of the best types, till after a time a lieredity of form, color, size and flavor, is well established. 
Plant Adaptability to Climate.

Corn.

Crops in 1642 .

Corn in 1654.
1038. Q. Do plants of warm latitudes adapt themselves to cold climates?

A. As a rule only so far as to quicken growth, or shorten the period of life. Corn, for instance, grown near the limit of its Northeru localities of production, no doubt was originally selected from Southern stocks of a marked early habit. Fixed types of plants grown far North do not acquire strength to withstand cold, simply a habit of quickly maturing to eseape cold. Many cross-bred plants, like some tobaccos, for example, possess a precocity fitting them for Northern climates better than the parents. Many natural conditions of plants can be changed by elimate; for example, the plants of North America bloom. ing and fruiting in their own appointed seasons ehange their habits when taken to South America and Australia, where the seasons are reversed.

1039. Q. Why is it that corn grown in the cotton States when brought as far North as Penusylvania will not ripen?

A. The planting of corn ripened under a Southern climate, in localities far North of its latitude of production, seems to completely upset its natural habit, a common occurrence in vegetable life, as sueh corn runs almost entirely to foliage, the function of leaf and stem development being so stimulated as to completely displace the function of seed production. The cause of this it is difficult, perhaps impossible, to answer to the satisfaction of every one. It may be due to several causes in combination, sometimes partially influenced by richer soil, more generally to increased moisture, or more even distribution of rain during the last half of the season of growth, a better conservation of water, for in Southern loealities the evaporation is greater, and transitions of soil moisture conditions more marked.

A Southern corn under any circumstances takes a greater number of days of growth to arrive at maturity, and when planted in the North simultaneously with Northern corn continues vigorous longer than the Northern sort, so much so as to be in a position to profit by August and September rains which come too late to extend the growth of the quicker maturing Northern varieties. Thus the formation of leaf tissue in the case of Southern corn is still further continued till finally the plant, yet in vigorous growth, enters the moister seasons of the Autumn when nothing will arrest the growth but frost.

1040. Q. What kind of crops, if any, did the early Indians cultivate?

A. Campanius, a Swede, who explored the valley of the Delaware in 1642 , wrote that among the Indians he found cultivations of hops, grapevines, plum trees, maize, calabash and a fibre like hemp.

1041. Q. What are some of the earliest references to the growth of corn in Pennsylvania?

A. In 1654, Peter Lindstrom, a Swedish engineer, surveyed the Delaware river, and wrote that he met with extensive cultivations, by the Indians, of corn ; the grain being of various colors, white, black, red, blue, 
brown, yellow and pied. That the yellow sorts were used for making bread, but that the blue, brown, black and pied were used in brewing and made a strong, dark-colored beer.

1042. Q. Will the fluwers of tomato plants and potato plants mix?

A. Yes, they will pollenize in cases where the plants be grown under glass and very practical efforts be made to effect cross-pollination, the tomato crossing with the potato and the potato with the tomato, but so Tomato and far nothing of any value has been obtained by such hybridization. The living plants can also be grafted upon each other; for instance, a potato plant can be cut down to within an inch or two of the root and a tomato stem grafted upon it, the abuve-ground plant being a tomato and producing fine fruit, and the below-ground plant being a potato, producing potato tubers; or to the contrary, a tomato plant can be cut down to within an incle or two of the soil and a potato stem grafted upon it. Of course the tomato root will not produce potatoes, but it will sustain the potato top above ground which will produce potato flowers, seed bulbs and sometimes abnormally developed small potatoes at the axles of the stems. These experiments are only of value and interesting in a physiological sense, nothing practical or of value can be expected from them.

D. LANDRETH \& SONS WILL AT ALL TIMES BE PLEASED TO RECEIVE QUERIES UPON ACRICULTURAL AND HORTICULTURAL SUBJECTS, AND INVITE SUCH CORRESPONDENCE. 


\section{INDEX.}

A.

PAGE.

Actinism ................. 33

Adaptability of Plants . . . . . . 191

Adulteration of Seeds . . . . . . 136

Advertising of Seeds. . . . . . 145

Advice, Agricultural . . . . . . 170

Adventurous Plants . . . . . . . 161

Agriculture, $34,54,66,74,89,90,99,113,122$,

Agricultural Societies ....... 54 Agricultural Stations. . . 90, 176, 187, 193 Air in Soil . . . . . . . . 180

Air Plants . . . . . . . 100, 105

Alfalfa............. 22, 52

Alluvial Soils. . . . . . . . 30

American Seeds . . . . . . . 160

Analysis, Vegetable....... 64

Anthracnose ............ 125

Artificial Heat. . . . . 25, 27, 104

Artichoke, French . . . . 42, 106

Arsenic............ 78

Ashes. . . . . . . . 30, 130, 175

Asparagus .....41, 46, 79, 86, 102, 170

Asphyxiation of Insects . . . . . 116

Autumn Leaves . . . . . . . . 34

B.

Bacteria. . . . . . . . 45, 191

Barley . . . . . . . . . . 38

Barnyard Manure . . . 32, 127, 138, 175

Beans, 14, 45, 46, 47, 48, 51, 52, 56, 57, 58, 72,

$74,81,88,96,97,109,110,114,115,121,125$,

142,161

Beets . . 15, 61, 75, 87, 106, 170, 172, 182, 185 Beet Sugar .......... 15, 61

Beneficial Insects . . . . . . 177

Bermuda Grass . . . . . 49, 58, 86

Bermuda Onions. . . . . . 43

Berries . . . . . . . . . 29

Bisulphide . . . . . . . 71, 147

Bleaching Celery. ............... 181

Blight.............. 77

Bloomsdale Pea . . . . . . . 119

Blue Grass . . . 22, 49, 59, 86, 129, 174

Bones........... . 83, 173

Bordeaux Mixture. . . . . 46, 81, 120

Botany . . . . . . . . . . 90

Breathing Pores........ 80, 182

Broccoll.......... 2, 72

PAGE.

....... 35

Bulbs ............. 2, 80

Butter Beans......... 59

C.

Cauliflower. . . . 39, 70, 87, 88, 122, 127 Cantaloupes, $7,8,86,99,109,110,117,122$, $126,127,128,129,143$

Cabbage, $11,12,13,33,47,53,65,75,77,81$, $81,88,90,93,94,96,106,110,113,116,118$, $123,124,128,130,160,175,183,181$

Canada Blue Grass . . . . . . . 22

Carbon ............... 31

Carrot........... 54, 137

Canning Vegetables . . . . 61, 62

Capital ............. 64

Calico Bug . . . . . . . . . 95

Cane............... 108, 162

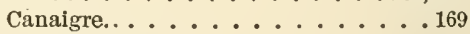

Carolina Rock . . . . . . . 171

Carnivorous Insects . . . . . . 177

Carnivorous Plants. . . . . . . 69

Cattle Food. . . . . . . . . . 164

Celery . . . 18, 71, 72, 98, 105, 125, 176, 181

Chemical Action ........ . 30

Charleston Rock . . . . . 31, 171

Chickory ......... 71, 112

Cheat or Chess .......... 76

Club Root ....... 12, 5s, 81, 182

Clouds ............. 29

Clover, scarlet ........ 23, 77

Climbers............ 14, 48, 142

Cloche........... 76

Clover . . . 23, 52, 76, 77, 108, 124, 135, 138 Climate...... 131, 136, 193, 194

Cow Feed . . . . . . . 108, 192

Cow Peas. . . . . 2, 58, 67, 76

Cows. . . . . . . . . . 172, 192

Corn, $16,17,38,46,63,64,89,92,93,97,101$, $104,109,115,118,123,139,140,141,163$, $168,170,175,177,182,183,184,192,193,194$, 195 Commercial Fertilizers, $31,32,44,77,83,87$, $89,108,137,173,179$

Collards ............ . 47

Cotton Oil . . . . . . . . . 160

Conch Grass. . . . . 49, 52, 112, 174

Colors....... 54, 70, 75, 98, 121 
PAGE.

Cotton ............. 58

Cos Lettuce. . . . . . . . . 75

Cold Framcs . . . . . . 100,103

Coffee. ............ 71, 112

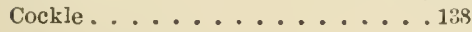

Cooking Reccipts. . . . . . . 154

Corn Consumption . . . . . . . 38

Covering Sceds. . . . . . . . 59

Crab Grass. . . . . . . 49, 52, 112, 174

Crows ................. 45, 121

Cross Bred. . . . . . . . . 31, 102

Cryptogams ............ 105

Cucumber, $5,6,53,60,61,81,89,: 03,109,110$, $124,126,139,175$

Culinary Vegetables ....... 2, 151

Cutworm .............. 77

Cultivation ........ 119, 121, 121

\section{D.}

Darmstadt Experimental Station. . . 176

Darnell. . . . . . . . . 149

Dates ........... 54, 81, 194

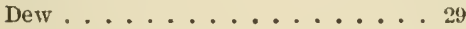

Degeneracy .......... 76, 103

Discovery in Agriculture. . . . . . 122

Destruction of Insects . . . . . . 82

Division of Farms . . . . . 35

Disease. . . . . . . . 78

Dissemination of Weeds . . . . 169, 176

Discrimination by Plants. . . . . . 104

Dodder............. 24

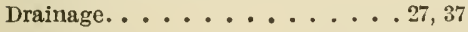

Drought. ....... 70, 72, 105, 124

Dry Soils . . . . . . . . . . . 78

Drilling Seeds ... . . . 90, 120, 127

\section{E.}

Edible Plants. . . . . . . . 193

Egg Plant . . 40, 74, 92, 95, 114, 153, 162, 171

Elements............ 32

Electric Light . . . . . . . . . 111, 116

Emulsion .......... 82, 84

Ensilage. . . . . . . 173, 189, 192

Ergot. ............. 98

Errors in Seeds. . . . . . . 85

Essential Fertilizers . . . . . . 64

European Vegetables. . . . . . . 103

Exports, Agricultural . . . . . 37, 38

Experimental Stations . . . 53, 152, 176, 192

Exhaustive Crops. . . . . 80, 105, 134

Exhalation ......... 80,182

\section{F.}

Farms. . . . . . . 35, 151, 159 Farmyard ..... 32, 127, 138, 173, 175

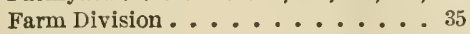

Farm Labor ............ 35

Fertilizer for Lawns PAGE.

Fertility .......... 31, 112, 131

Fertilizers . . 47, 58, 64, 98, 108, 119, 137, 165

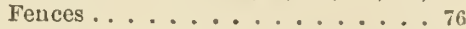

Fish Mauure . . . . . . . . 4 47

Fibers....... 25, 37, 53, 97, 194

Firming the Soll ...... 27,72,94

Fish Culture ........... 93

Florida Rock ......... 31, 171

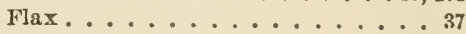

Fluctuation in Prices ..... . . 39

Flowers.......... 73, 120, 131

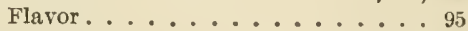

Foliage.............. 24, 34

Forcing Seeds . . . . . 25, 137, 144, 170

Forcing Houses . . . . . 102, 118, 190

Food...........69, 82,83

Fruit. . ...... 1, 29, 37, 65, 105

Frost............. 28, 29, 34

Freshness Retained . . . . . 135

Fumigation ............ 118

Fungicides. . . . 46, 53, 81, 120,125

Fungi, 12, 28, 46, 48, 49, 57, 58, 70, 73, 77, 78,

$81,87,92,98,99,101,105,106,113,114,119$,

$122,128,165,182$

G.

Gardening, $17,19,30,54,57,60,65,66,80$, $84,102,133,144,148,181$

Garden, Plan of......... 17

Garlic. . . . . . . . . . 140 Germination, $33,44,48,58,69,80,85,88$,

$103,138,142,183,188$

Germs, Fungous ......... $10 \overline{5}$

Glasshouse ...... 102, 112, 118, 190

Glucose.............. 34

Gourds ........ 3, . 3194

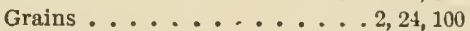

Grapes . . . . . . . . 100, 101 Grass, $21,22,23,47,49,50,52,58,59,78,97$,

$112,129,168,174,180$

Greenhouse Cucumber . . . . . . 6 Green Manures . . 16, 45, 58, 111, 122, 167 Growth ......... 98, 114, 180 Grubs ....... 78, 79, 87, 118, 177 Guano, Peruvlan ..... . 32, 77, 8 ?

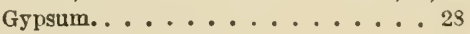

H.

Hammond's Thrip Juice . . . . . 28 Harlequin Bug . . . . . . . . . 74 IIay........ 22, 23, $38,116,165$ Heat, Artificial. ...... 27, 33, 112 Hellebore ..........2 28 Ilerbs ................. 50 Herd Grass .......... 22, 23 
Heredity . . . . . 60, 103, 116, 151

Horse-radish ......... 18, 146

Horticultural Society . . . . . 54

Hotbeds . . . . 25, 27, 100, 103, 101

Humus . . . . . . . . . . . 131

Humidity . . . . . . . 97, 100, 123

Hybridization . . . 3, 89, 100, 102, 123, 195

Hydrogen ............ 31

\section{I.}

Implements. . . . . . . . 31, 162, 192 Importations........ 37, 52, 185 Influence of Parents . . . . . . 60, 103 Inhalation . . . . . . . 80, 182 Inoculation of Soils . . . . . 45, 68 Inorganic Parts. . . . . . . . . 31 Insecticides, $28,34,46,56,70,71,73,82,128$,

Insectivorous Bugs . . . . . . 115, 177 Insects, $9,13,46,57,60,68,69,70,71,74,76$,

$77,78,79,82,84,91,95,96,100,101,106$, $113,116,118,119,123,124,133,139,177$

Introduction of the Tomato . . . . 115

Ivy ...................... 103

\section{J.}

Japan Clover........... 52

Johnson Grass . . . . . . . 49

K.

Kainit ............... 108

Kerosene ............. 82,84

King Crabs.......... 103

Kohl Rabi.......... 40

\section{L.}

Labor on Farm . . . . . . . 35

Lands ............. 68

Land Sales........... 37

Land Values. . . . . . . . 34

Larvæ .............. . . 82

Latitude . . . . . . . . 136, 194

Lawn . . . . . 19, 21, 23, 111, 121, 159

Leaf Rakings. . . . . . . . . . 93

Leek ............. 140

Legumes . . . . . . . . 2, 23, 55,67

Lettuce, 41, 54, 94, 110, 119, 123, 126, 128, 129 s 188,189

Lice ......... 81, 113, 116, 118

Licorice . . . . . . . . . . 104

Light. . . . . . . . . . 33

Lima Beans . . . . . . . 14, . . . . . . .

Lime . . . . . . 28, 30, 31, 33, 46, 83, 172

Linsced Oil . . . . . . . . . 160

Liquid Manure . . . . . . . . 33

Live Stock . . . . . . 39, 172, 192

Loam ................ 30
PAGE.

Lobos Guano . . . . . . . . 77

Locust . . . . . . . . 68, 168

London Purple......... 28

Low Prices . . . . . . . . 35

M.

Machine Development . . . . 31, 162, 192

Maggot ................ 91

Mangel Wurzel . . . . . . 15, 182 Manure, $15,30,31,32,33,44,47,51,53,56$, $58,69,77,80,83,87,88,89,101,103,105$, $110,111,127,133,139,141,164,173,175,178$,

Market Garden, 18, 19, 60, 65, 66, 69, 185, 190 Marl ............. 107

Maturity of Fruits. . . . . . . 105

Maturity of Peas . . . . . . . 150

Maturity of Vegetables........ 183

Measuring Land . . . . . . . . . . 174

Melon, 9, 48, 49, 56, 73, 82, 87, 113, 118, 159,

Mildew. . . . . . . . . 48,87

Millet................ 91

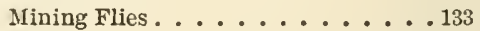

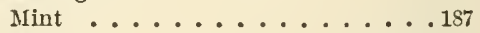

Moisture........ 97, 100, 123

Molasses . . . . . . . . 187

Mold . . . . . 28, 48, 78, 81, 119, 165

MIoles................. 135

Moon .................... 53, 98, 103

Moss................. 101

Mule Plants . . . . . . . . . 102

Mushroom ......... 43, 114

Mustard .............. 92

N.

Nitrate of Soda. . . . . . 53, 75, 113 Nitrogen . . 31, 50, 69, \$3, 138, 166, 171, 178 Nitrogenous Manures . . . . . . 170 Nomenclature ........ 51,74 Nutmeg Melons ........ . 7 Nutrition .................... 69,176

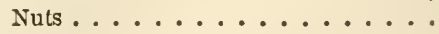

o.

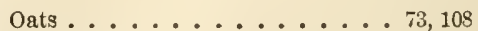

Oats, Hay . . . . . . . 47

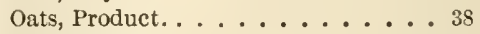

Offsets ............ 2

Oils, Vegetable....... 133, 160

Okra........................... 1180

old seeds .......... . . 44,87 Onious, 43, 56, 73, 84, 86, 89, 90, 91, 94, 99, $105,106,127,130,131,132,139,140,160,168$,

154

Onion Sets...... 43, 46, 71, 75

Orchid Grass . ......... 22 
Organic Constituents........ 31

Original Types . . . . . . . . 1s9

Origin of Plants .......47, 189

Over-manuring........ 51

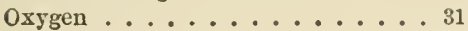

P.

Parasites........... 100,105

Parental Influence . . . . . . 103, 151

Paris Green . . . . 28, 34, 56, 70, 73, 78, 82

Parsnip.....................

Pasturage Grass . . . . . . 21,59

Per Bug...........68,70

Peach, Yellow......... 52

Peanuts................. 170

Pearl Sets ............ . 94

Peas, $3,13,14,15,45,58,61,73,76,78,57,99$, $104,107,108,119,124,129,142,149,150$

Peas, Cow ........ 2, 59, 67, 76

Peat............30,128, 131

Pedigree Seeds . . . . . . . 151

Peppers. ............... 1s4

Perennial Beans . . . . . . . 57

Periods.......... 54, 85, 88, 181

Permanent Pasture ........ 21

Persian Insect Powder . . . . . . 28

Perspiration ........... 103

Peruvian Guano . . . . . 32, 77, 89

Phonograph Pea......... 124

Phosphate...... 31, 32, 83, 87, 179

Phosphoric Acid . . . . 129, 130, 171

Phylloxera . . . . . . . 100,101

Pickles........... 60,61

Pigs ...................... 161

Plant Adaptability . . . . . . . 194

Plant Constituents ........ 31

Plant Food . . . . . . . 69, 176

Plant Origin . . . . . . . . 47

Plants to Acre.............. 133

Plow ......... 36, 79, 121, 174

Poison ......... 78, 105, 183

Poisoned Soils ......... 165

Pole Beans ......... . . 56

Pollen. . . 3 3 80, 117, 136, 137, 143, 179

Potash ........ 31, 50, 83, 87

Potatoes, 4, 38, 48, 52, 62, 79, 81, 88, 102, 104, $10 S, 121,123,129,132,140,175,179,155,186$,

Potato Seed ..................

Prescription Grass . . . . . . 60

Preservation of Seed ........ 113

Profits ......... 57, 69

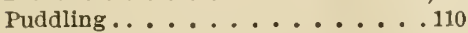

Pulverizing Soil ......... 174

Pumpkin ......... 54, 186

Pungent Vegetables ........ 111
Q.

PAGE.

Quarantining Plauts....... 69

R.

Radiation ........... 20 Radish . 10, 71, 74, 8S, 89, 107, 116, 122, 143 Railroads ........... 34 Ramie ............ . 25

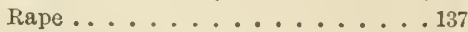

Receipts, Cooking ........ 151

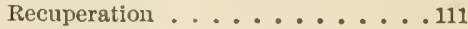

Red Top Grass . . . . . . . . . 22

Resin............. 77

Resistant Grasses. . . . . . . 168

Restorative Crops ........ 178

Rhode Island Bent Grass . . . . . . 22

Rhubarb............ 72

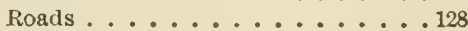

Rolling ............. 175

Roots. . . . . 18, 134, 161, 172, 173

Rotation....................... 166, 182

Runners ............. 14, 142

Rust ............. 14, 70, 81

Ruta Baga ......... 86, 172

Rye ............ 38, 78, 130

S.

Sap. ............ 27

Sales of Land. . . . . . . . 37

Salads ............ . 39

Salt.................... $46,54,171$

Sand Grass .......... . 47

Salting Cucumbers. ....... 60

Sand .................. 70, 101

Savoy. . . . . . . . . . 75,171

Scarlet Clover . . . . . . . . 23

Scientific Agriculture . . 90, 176, 187, 193

Seeds, Forcing . ....... 25

Sex ...... 53, 60, 91, 103, 151, 180

Seeding ........ 54, 90, 120,127, 181

Seasons....... $54,57,85,88$

Selling . . . . . . . . . . 105

Seeds, 54, 80, 84, 107, 113, 123, 132, 135, 137,

$143,144,146,149,151,152,159,160,162,181$

Selection. . . . . . . . 116

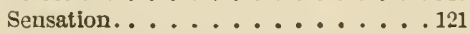

Seed Control ...................... 150

Shipments of Fruit. . . . . . 29

Shamrock ................. 135

Shallots .............. 140, 165

Sick Soils . . . . . . . . 165, 167

Silos. . . . . . . . 173, 189, 192

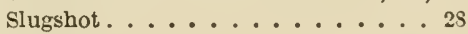

smut. ....... 73, 98, 99, 101

Snow. . . . . . . . . . 29

Soil, $30,45,58,68,78,105,111,112,134$, $142,167,174,177,180$

Soda................. 31,75 
PAGE.

Soluble Phosphate . . . . . . . 32

Soil Inoculation. . . . . . . 45, 68

Soda Nitrate . . . . . . 53, 75, 113 Sorghum. . . . . . 104, 109, 175

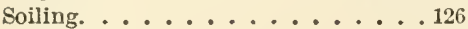

Sorrel ............. 127

Sowing Seeds. . . . . . . . . 144

Spinach. . ... 10, 15, 53, 75, 110, 171

Sports ........ 50,60, 122, 189

Spraying. . . . . . . . 53, \$1, 125

Squash . . 51, 54, 68, 81, 82, 123, 124, 186

Storage Corn ........... 17

Stable Manure . . . . . . . 30, 141

Steam Plowing ......... 36

Stations, Experimental . . 90, 176, 187, 193,

Starch........... 80, 176

String Beans .......... 57

Sugar Beets . . . . . . . . 15, 61

Sulphuric Acid ............ 32

Sun. ................. 33, 102,106

Subsoiling ............ 35

Superstitions. . . 29, 33, 37, 57, 76, 98, 103

Sugar. . . . 34, 37, 111, 162, 170, 172, 187

Sunhouses ........................ 102

Sunburn .................. 130

Sugar Cane . . . . . 108, 114, 162

Sunflower ....................... 113

Sweet Potatoes ....... 4, 62, 179

Sweet Peas........... 73

Swedes........... 126, 164

T.

Tariff. .................... 167

Tassel of Corn .......... 141

Texas Blue Grass. . . . . . . 49

Tennis Court . . . . . . . . 128

Testing Seeds . . 44, 56, 133, 137, 152, 163, 184

Thinning. .......... 85

Tillage ............. 53

Tobacco......... 38, 55, 92, 160

Toads. ..............48

Top Onions ......... 56, 71, 86

Tobacco Soils. . . . . . . . 55

Tomatoes, $10,50,51,54,62,77,95,102,107$, $108,109,115,119,130,170,195$

Trifolium Incarnatum . .

. . 23

Transplanting ..... 76, 100, 110, 144
Trial Grounds. . . . . . 53, 152, 192

Tubers ............ 2, 80 Turnip, 17, 56, 72, 79, 81, 99, 107, 110, 126, $127,135,145,164,172,178,155$

Types.... . . . . . 60, 189

Types, Original. . . . . . 189

\section{U.}

Unripe Seeds. . . . . . . . 73, 78

Unvital seed ........... 85, 117

\section{v.}

Values of Turnips. . . . . . . . 185

Variability. . . . . . 50, 60, 163, 189

Vegetable Analysis. . . . . . . 64

Vegetables. . . 1, 2, 62, 65, 103, 119, 123, 188

Vegetable Garden . . . . . . 17, 19, 188

Vegetable Mold . . . 28, 48, 78, 81, 119, 165

Vegetable Products. . . . . . . . 31

Vegetable Oils.......... 133

Vegetation. ............. 33

Vitality, $17,44,56,69,73,80,93,133,137,162$,

163,184

Vine Seeds . . . . . . . . . . 159

W.

Watermelon, $7,9,53,89,99,110,126,129$, $138,139,147$

Water. ........... 29, 104

Wax Beans. ........ 46

Warranted Seeds. . . . . . . 162

Washed Lands . . . . . . . . . . 68

Wash, Resin . . . . . . . . 77

Water Cress . . . . . . . . . 143

Weevil.............. $70,71,96$

Weeds, 15, 23, 48, 91, 96, 110, 111, 124, 128,

$169,176,177$

Web Worm. . . . . . . 106, 139

Weights........ 135, 181

Wheat .... 2, 3, 38, 48, 86, 97, 132, 166

White Grub ......... 79

Wild Potatoes. . . . . . . . . 4

Wintering Roots ......... 18

Wood Ashes. . . . . . . . 30, 130, 175

Worms ......... 51, 88, 106, 183

Wire Grass. ...... 49, 52,112, 174 


\section{ADVERTISEMENT.}

The only advertisement in this book is that below of the firm of

D. Landreth \& Sons, established in 1784 , one of the

thirty-four firms in the United States of over

one hundred years' unbroken man-

agement by the direct de-

scendants of the

Founder.

\section{IANDRETH \& SONS, \\ SEED FARMERS \\ AND MERCHANTS,}

are prepared at all times to execute Mail or Express orders for

\section{SEEDS, BULBS OR IMPLEMENTS.}

\section{Catalogues and Prices}

furnished on application.

Nothing for the Farm or Garden which they cannot supply.

Write for what you want and prices will be quoted. Address

D. LANDRETH \& SONS,

...Seedsmen...

PHILADELPHIA. 




THE LIBRARY

UNIVERSITY OF CALIFORNIA

Santa Barbara

THIS BOOK IS DUE ON THE LAST DATE STAMPED BELOW.

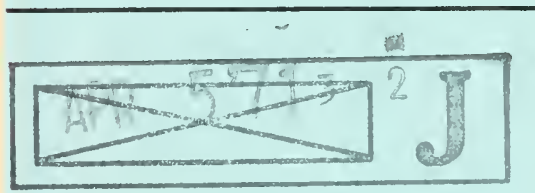




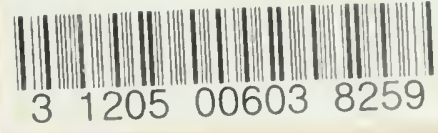

NN

UC SOUTHERN REGIONAL LIBRARY FACILITY

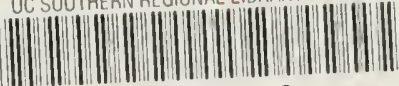

AA $000991310 \quad 4$ 


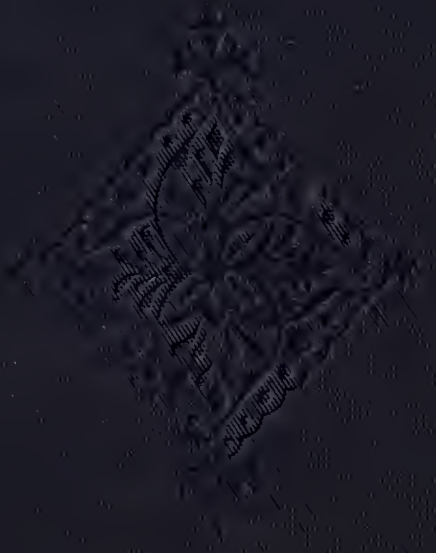

